\title{
MINERALOGIA E GÊNESE DE SOLOS ORIGINADOS DE ROCHAS DA FORMAÇÃO IRATI: REGIÃO DE PIRACICABA-SP
}

MARIANO CALERO MERINO

Engenheiro Agrônomo, M. Sc.

ORIENTADOR : Prof. Dr. JOSÉ LUIZ IORIATTI DEMATTÊ

Tese apresentada à Escola Superior de Agricultura "Luiz de Queiroz", Universidade de São Paulo, para a obtenção do Título de Doutor em Agronomia, Área de Concentração: Solos e Nutrição de Plantas. 
Dados Internacionais de Catalogação na Publicação (CIP) DIVISÃO DE BIBLIOTECA E DOCUMENTAÇÃO - Campus "Luiz de QueirOz"/USP

Calero Merino, Mariano

Mineralogia e gênese de solos originados de rochas da Formação Irati : região de Piracicaba-SP / Mariano Calero Merino. - . Piracicaba, 1999.

207 p. : il.

Tese (doutorado) - Escola Superior de Agricultura Luiz de Queiroz, 1999.

Bibliografia.

1. Formação Irati 2. Formação do solo 3. Mineralogia do solo 3. Morfologia do solo 4. Pedologia 5. Propriedade fisico-quimica do solo I. Título 


\title{
A Deus Milagroso
}

"Senhor Cautivo de Ayabaca" pela sua infinita Misericórdia

\section{OFEREÇO}

\author{
A meus pais: Víctor Manuel e Zoila Angélica \\ Irmãos: A. Aurora., Hernando de J., Gerardo, Santiago
}

\section{MEU RECONHECIMENTO}

A minha irmã: Ofelia E., que foi atraida pelo encanto de Deus!

\section{MINHA HOMENAGEM}

\begin{abstract}
A Kriss Mariano \& Mariano Rouget
Meus filhos, razão da minha vida, que acompanharam o sucesso do seu pai
\end{abstract}




\section{AGRADECIMENTOS}

Ao Professor Dr. José Luiz loriatti Demattê, pela orientação, incentivo ensinamentos, dedicação e amizade recebidos.

À Escola Superior de Agricultura "Luiz de Queiroz", (ESALQ) da Universidade de São Paulo (USP), pela possibilidade e condições oferecidas para o desenvolvimento do Curso de Pós Graduação.

À Coordenadoria de Aperfeiçoamento de Pessoal de Ensino Superior (CAPES), pela concessão de bolsa de estudo.

Aos Professores do Departamento de Solos e Nutrição de Plantas da ESALQ/USP Doutores: F.A. Monteiro, Quinino A. de Camargo Carmello, A. Pires da Silva, A. Marconi, A.J. Melfi, R.R. Aloisi, Z. Zillmar Marcos, R.S. Pacovsky, e todo o Staff de Professores, pela sua colaboração e extrema cordialidade com que me acolheram e ensinaram. Em forma muito especial ao Dr. C.A. Clemente pelas constantes trocas de idéias e apoio amigo nas horas mais dificeis.

Aos Professores do Departamento de Solos da Facultade de Agronomia da "Universidade Nacional de Piura" (UNP), Dr. C.A. Delgadillo; M.Sc(s): J. Remigio, J.E. Lapeyre; Engenheiros: W.A. Farías, V.M. Requena e D.R. Silva, pelo apoio e paciência durante o meu afastamento.

Aos Funcionários e Técnicos de laboratório: Senhora Maria Elizabete H.B. Guimarães pela sua valiosa contribuição na difração de raios- $x$ e ATD; ao Sr. H. Sampaio do IAG-(NUPUGEL), pela sua ajuda nos estudos de MEVmicroanálise e pela amizade oferecida.

Aos Senhores: W.J. Rosignolo e L. Dias, pela orientação no laboratório de Física de Solos; D. Grissotto, S.F de Mello e, à Senhora F. Morales pela amizade fraterna.

Ao Prof. Dr. E. Kitajima, do NAP/MEPA, pelo acompanhamento, ensino e paciência na MEV e MET e, à Senhorita S. Machado pela ajuda no revelado fotográfico. 
Aos Professores da UNESP-Rio Claro: Dr. A.J. Ranalli Nardy, pela sua valiosa ajuda na fluorescência de raios- $X$, e ao Dr. J.R. Jimenez-Rueda pela orientação construtiva e amizade.

Ao Professor Ph.D. José A. Estrada, Professor Emérito da UNA "La Molina", por me recomendar e acreditar no meu sucesso doutoral.

À Senhorita M. Campos G., pelo apoio constante, colaboração e amizade durante os estudos Pós Graduais.

Em forma especial à senhora M.S. de C. Ferraz, pela ajuda na confecção final da tese e amizade.

A meus colegas amigos: E. Fraga da Silva, W. Klein e E. Do Nascimento, pelo convívio fraterno e ajuda.

Ao Professor Dr. Paulo L. Libardi pela sua gentil orientação em Física de Solos e, ao amigo Robinson L. Tuon pela amizade e ajuda. 


\section{S U M Á R I O}

Página

LISTA DE FIGURAS …................................................................ Vii

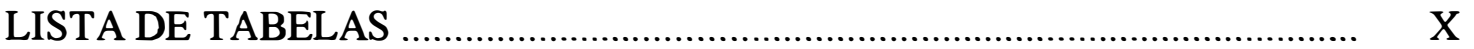

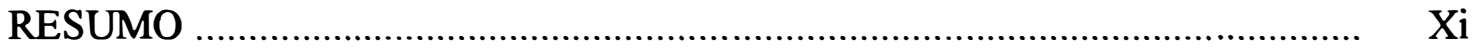

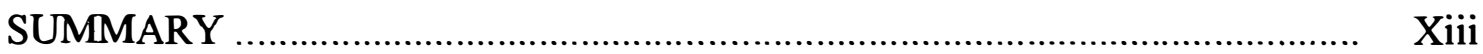

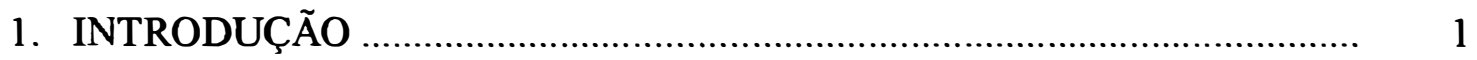

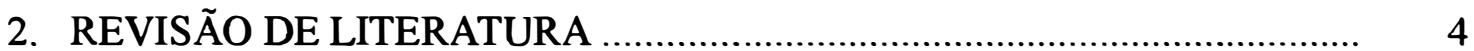

2.1. Geologia e Geomorfologia: Formação Irati..... 4

2.1.1. Geologia........................................................................ 4

2.1.2. Geomorfologia ........................................................ 7

2.2. Significado geológico da diagênese dos sedimentos ........................... 8

2.3. Gênese de solos de boa drenagem ................................................ 9

2.4. Gênese de solos com drenagem impedida ..................................... 11

2.5. Processos específicos de gênese ..................................................... 13

2.5.1. Oxidação-Redução ................................................................. 13

2.5.2. Hidrólise ................................................................... 15

2.5.3. Ferrólise (Destruição de argilominerais) ............................... 16

2.5.4. Bioturbação.................................................................. 17

2.5.5. Eluviação-Iluviação (Lessivagem) e gênese do horizonte Álbico (E) 
2.5.6. Mineralogia da argila: dessilicatização

3. MATERIAL E MÉTODOS ……............................................................... 25

3.1. Caracterização do meio físico ……………………………………….... 25

3.1.1. Localização ....................................................................... 25

3.1.2. Geologia .................................................................... 28

3.1.3. Geomorfologia ............................................................... 28

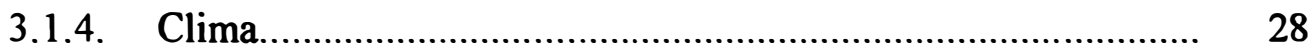

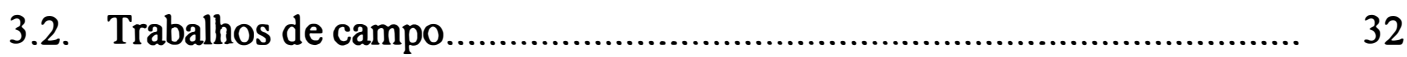

3.3. Análises de Laboratório ....................................................................... 34

3.3.1. Análises fisicas.................................................................... 34

3.3.2 Análises químicas................................................................. 37

3.3.3. Preparo das amostras para análise mineralógica...................... 38

3.3.4. Difração de raios-X...................................................................... 39

3.3.5. Fluorescência de raios-X.......................................................... 40

3.3.6. Análise térmica diferencial................................................... 41

3.3.7. Preparo das amostras para microscopia ótica............................ 41

3.3.8 Preparo das amostras para micromorfologia........................... 42

3.3.9. Microscopia Eletrônica de Transmissão (MET)...................... 42

3.3.10. Microscopia Eletrônica de Varredura (MEV).......................... 42

3.3.11. Microsonda .......................................................................... 43

3.3.12. Cálculos granulométricos...................................................... 43

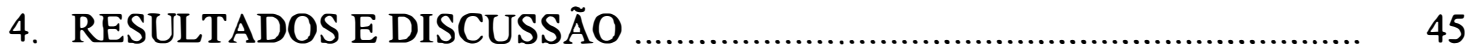

4.1. Morfologia dos solos na catena ......................................................... 45

4.2. Propriedades fisicas................................................................................. 67 
4.3. Propriedades químicas............................................................. 80

4.4. Espectografia de Raios-x.......................................................... 94

4.5. Mineralogia .................................................................. 104

4.6. Processos genéticos envolvidos na seqüência estudada....................... 119

4.7. Alteração dos minerais da sequência estudada ................................. 138

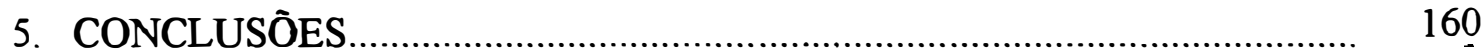

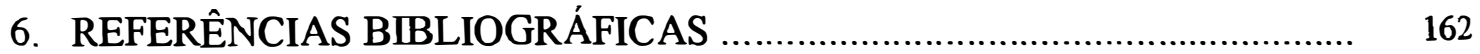

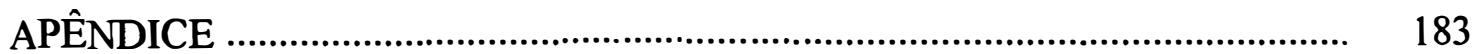




\section{LISTA DE FIGURAS}

Página

3.1. Localização da área de estudo no município de Saltinho no Estado de São Paulo

3.2. Esquema (sem escala) ilustrando a posição dos perfis T1 ao T4 este na depressão assim como a seqüência dos horizontes. A oscilação do lençol freático não atinge o $\mathrm{T} 1$

3.3. Seqüência estratigráfica da Formação Irati-Membro Assistência. (A) Exposição de ritmitos nos estratos na Pedreira do calcário "Teixeira" a 5 $\mathrm{m}$ da catena Saltinho (SP). (B) Fósseis de Pteridofitas e Mesossaurídeos Permianos (Kazaniano)

3.4. Mapa geológico da Quadrícula indicando o município de Saltinho que foi a área estudada. Fonte: IPT ( 1981)

3.5. Balanço hídrico da região de Piracicaba

3.6. Fluxograma dos trabalhos de laboratório

4.1. Principais tendências evolutivas dos horizontes diagnósticos dos perfis T1 aoT4 da catena estudada 50

4.2. Fotomicrografias de seção delgada dos horizontes do perfil T1

4.3. Curvas de retenção de água dos perfis T3 e T4.

4.4. Relação da AF/AT e AMF/AT dos solos

4.5. Distribuição estatística das 5 frações de areia referentes aos solos da catena

4.6. Distribuição dos micronutrientes e o elemento Na nos perfis.

4.7. Difratogramas de raios-X da fração areia em amostras deferradas. Espaçamentos em nanômetros. 
4.8. Difratogramas de raios- $X$ da fração silte em amostras deferradas dos perfis estudados. Espaçamentos em nanômetros.

4.9. Difratogramas de raios- $X$ da fração argila em amostras deferradas $K$ $25^{\circ} \mathrm{C}$, dos horizontes Ap dos perfis T1, T2, T3 e T4. Espaçamentos em nanômetros.

4.10. Difratogramas de raios- $X$ da fração argila em amostras deferradas $K$ $25^{\circ} \mathrm{C}$, dos horizontes Bt1 (T1); Bt1 (T2); Btgv1 (T3) e Btgvl (T4). Espaçamento em nanômetros.

4.11. Difratogramas de raios- $X$ da fração argila em amostras deferradas $K$ $25^{\circ} \mathrm{C}$, dos horizontes (BC)1-(T1); BC-(T2); Btgv2-(T3); C1g-(T4). Espaçamentos em nanômetros.

4.12. Difratogramas de raios- $X$ da fração argila em amostras deferradas do perfil $\mathrm{Tl}$ : $\mathrm{K} 25^{\circ} \mathrm{C}, \mathrm{K} 350^{\circ} \mathrm{C}, 550^{\circ} \mathrm{C}, \mathrm{Mg}$ e $\mathrm{Mg}$-glicol, dos horizontes $\mathrm{Bt}$, BC e C5. Espaçamentos em nanômetros

4.13. Difratogramas de raios- $X$ da fração argila em amostras deferradas do perfil $\mathrm{T} 2$ : $\mathrm{K} 25^{\circ} \mathrm{C} ; \mathrm{K} 350^{\circ} \mathrm{C}$; $\mathrm{K} 550^{\circ} \mathrm{C}$; $\mathrm{Mg}$ e $\mathrm{Mg}$-glicol dos horizontes $\mathrm{Bt}$, (BCg)le Clg. Espaçamentos em nanôemetros

4.14. Difratogramas de raios- $X$ da fração argila em amostras deferrificadas do perfil T3: $\mathrm{K} 25^{\circ} \mathrm{C} ; \mathrm{K} 350^{\circ} \mathrm{C} ; 550^{\circ} \mathrm{C} ; \mathrm{Mg}$ e $\mathrm{Mg}$-glicol dos horizontes Btgvl e Btgv2. Espaçamentos em nanômetros.

4.15. Difractogramas de raios- $X$ da fração argila em amostras deferradas do perfil T4: $\mathrm{K} 25^{\circ} \mathrm{C} ; \mathrm{K} 350^{\circ} \mathrm{C}$; $550^{\circ} \mathrm{C}$; $\mathrm{Mg}$ e $\mathrm{Mg}$-glicol dos horizontes $\mathrm{E}$, Btgv2, C1g e C2. Espaçamentos em nanômetros.

4.16. Termogramas em amostras deferradas da fração argila dos principais horizontes dos quatro perfis estudados mostrando os picos da caulinita e da esmectita e ou vermiculita 
4.17. Micrografias (MEV) de diferentes horizontes e camadas dos solos estudados.

4.18. Picos espectrais da microanálise das micrografias (MEV) nos perfis estudados.

4.19. Fotomicrografias (seção delgada) e micrografias (MEV) da alteração dos minerais na seqüência de $\mathrm{A}$ até $\mathrm{V}$

4.20. Picos espectrais das micrografias das Figuras 4.19 na seqüência de I até $T$ 


\section{LISTA DE TABELAS}

Página

3.1. Balanço hidrico Thornthwaite-Mather (1955) ...................................... 31

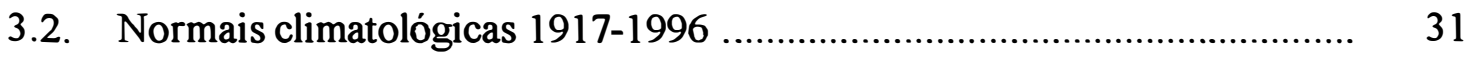

3.3. Principais espaçamentos interplanares utilizados no reconhecimento de minerais da fração argila ............................................................... 40

4.1. Resumo das características morfológicas dos perfis estudados ................ 46

4.2. Curvas de retenção de umidade, densidades do solo (Ds) e da partícula (Dp) e Porosidade dos solos estudados............................................... . 68

4.3. Resultados granulométricos dos perfis em porcentagem........................ 73

4.4. Resultados analíticos dos principais parâmetros químicos dos solos estudados

4.5. Resultados do índice $\mathrm{Ki}$ dos solos estudados

4.6. Ferro total determinado pelo ataque sulfúrico, ferro extraido pelo DCB e ferro extraído pelo oxalato

4.7. Análise química do $\mathrm{P}$, enxofre, micronutrientes e o elemento $\mathrm{Na}$.

4.8. Análise por espectrografia de raios- $X$ da fração areia fina dos solos derivados da Formação Irati-Piracicaba.

4.9. Análise por espectrografia de raios- $X$ do solo total.

4.10. Análise Térmica Diferencial de alguns horizontes diagnósticos da catena Saltinho

4.11. Análise semi-quantitativa dos minerais da fração argila, em porcentagem. 


\title{
MINERALOGIA E GÊNESE DE SOLOS ORIGINADOS DE ROCHAS DA FORMAÇÃO IRATÍ: REGIÃO DE PIRACICABA-SP
}

\author{
Autor: MARIANO CALERO MERINO \\ Orientador: Prof. Dr. JOSÉ LUIZ IORIATTI DEMATTÊ
}

\section{RESUMO}

Na depressão Periférica Paulista da Bacia Sedimentar do Paraná, nas proximidades do Arraial de São Bento, no município de Saltinho, Estado de São Paulo, é possível encontrar solos bem drenados associados a solos mal drenados, o que vem dificultar em muito as práticas de manejo, assim como sua utilização intensiva. Nesta região realizou-se uma pesquisa com o intuito de estudar as associações físicas mineralógicas e químicas de solos de boa drenagem a drenagem restrita, desenvolvidos de rochas da Formação Irati.

Num trajeto de $180 \mathrm{~m}$ foram abertas 4 trincheiras indo da trincheira de melhor drenagem, designado como T1 (Podzólico Vermelho Escuro, PE), até a trincheira T4 de pior drenagem, designado como T4 (Planassolo Plintico, Vértico, PL), no centro da depressão. As trincheiras T2 (PE) e T3 (Pozólico Vermelho Amarelo, PV) são intermediárias. Após amostragens dos principais horizontes e camadas, feitas até a rocha, constituida por argilitos e/ou folhelhos associados com o calcário, análises físicas, químicas e mineralógicas foram efetuadas. Os dados morfológicos, granulométricos e mineralógico indicaram a homogeneidade no material de origem.

A medida que se transloca do $\mathrm{T} 1$ para o $\mathrm{T} 4$ a ação das condições dos ambientes aeróbicos e não aeróbicos se manifestam e uma série de reações se processam, principalmente processos de oxi-redução do ferro. Neste processo a redução do $\mathrm{Fe}^{3+}$ para $\mathrm{Fe}^{2+}$ produz um aumento na concentração de $\mathrm{Mn}^{\mathrm{n}+}$ e uma redução no $\mathrm{pH}$, 
induzindo a protólise das lâminas de minerais de argila tornando-os instáveis e possiveis de destruição total e/ou parcial. O meio fica mais ácido e desaturado. Nestes processos parte dos minerais do horizonte argílico do $\mathrm{Tl}$ são gradativamente destruídos, principalmente pela ferrólise formando horizontes de transição ao longo da catena e culminando com a formação do horizonte álbico mais arenoso e mais claro no T4. Processos de dessilicatização foram observados sempre no sentido rocha ao horizonte superficial em todos os perfis estudados, assim como processos de bissialitização no sentido $\mathrm{T} 1$ ao $\mathrm{T} 4$.

A dissolução das "bonecas de sílex", processo este que aumenta do $\mathrm{Tl}$ ao T4, foi também comprovado. $O$ processo de bissialitização teve seu grau máximo nos horizontes inferiores do $\mathrm{T} 4$, culminando com a formação de estruturas em forma de cunha e o caráter vértico. A transformação do horizonte álbico no T4 pela destruição do argílico é sugerido. 


\title{
MINERALOGY AND GENESIS OF SOILS DERIVED FROM IRATI ROCKS FORMATION -IN THE PIRACICABA REGION, SÃO
}

PAULO STATE.

\author{
Author: MARIANO CALERO MERINO \\ Adviser: Prof. Dr. JOSÉ LUIZ IORIATTI DEMATTÊ
}

\section{SUMMARY}

In the Piracicaba region located in São Paulo State, occur soils developed from the geologic Irati Formation, represented by shale, siltstone and limestone materials rocks. It is very common in this area the occurrence of a well-drainage soils associated with a restricted drainage soils. In a transect of $180 \mathrm{~m}$ was open four pits, designated as T1, the well-drainage soils, a Dark Red Podzolic soil, toward the center of the depression, designated T4, a Plinthic, Vertic Planosol.

The T2 and T3 are intermediate soils. The main horizon and layers were sampled until the bed rocks or when the silica beds was reached. In this material physical, chemical and mineralogical analysis were determined. The data of mineralogy, sand ratios analysis and titanium distribution along the soils transect, indicate homogeneity in the parent material.

Going from T2 to T4 soils, the action of aerobic and anaerobic conditions increase and several oxidation-reduction reactions are processed. In the iron reduction process thus are an increase in $\mathrm{Mn}^{2+}$ and $\mathrm{H}^{+}$concentration and $\mathrm{pH}$ reduction, inducing the proteolysis of layers of the minerals. In this new conditions the minerals are unstable and can be total or partially destroyed.

In these processes part of mineral of the argillic horizon from $\mathrm{T} 4$ profile, are gradually destroyed culminating in the formation of an albic horizon. 
Dessilicatization process occur from rocks upward surface horizons, with an increase amount of kaolinite and decrease of 2:1 minerals. By the other way a silication process occur from $\mathrm{T} 1$ to $\mathrm{T} 4$ profiles, mainly in the $\mathrm{Bt}$ and $\mathrm{C}$ horizons. In these processes there are an increase in 2:1 minerals and decrease in 1:1 minerals. 


\section{INTRODUÇÃO}

A Depressão Periférica Paulista é uma unidade morfoescultural da Bacia Sedimentar do Paraná e apresenta uma sucessão de rochas sedimentares das mais variadas granulometria; indo desde os arenitos até os folhelhos e/ou argilitos. As rochas eruptivas podem fazer parte deste pacote, estando associadas a tais rochas sedimentares ou recobrindo essas formações. No território paulista esta unidade apresenta altitudes entre 600 a 750 metros, sendo que as altitudes maiores margeiam as escarpas da frente da Cuesta sustentadas principalmente pelos derrames basálticos.

A morfoescultura desta depressão está subdividida nas seguintes unidades morfológicas: Depressão de Moji-Guaçu, Depressão do Médio Tietê e Depressão do Paranapanema. Quanto à litologia da Depressão de Moji-Guaçu é representada basicamente pelos arenitos finos, argilitos, siltitos, calcário sedimentar e folhelhos da Formação Irati (Ross \& Moroz, 1997).

Nesta heterogeneidade de rochas, ocorrem solos das mais diversas natureza e composição, com intenso reflexo nas atividades agrícolas. Numa mesma encosta é possivel encontrar 3 a 4 solos totalmente diferentes, o que vem dificultar em muito as práticas de manejo, assim como sua utilização intensiva. Solos rasos associados a solos mais profundos, de gradiente textural bastante acentuado são comuns. Solos eutróficos associados aos distróficos ou álicos, são ocorrência freqüente nas encostas destas regiões. Especificamente em relação às rochas da Formação Irati, tem-se observado na região de Piracicaba, a ocorrência de solos avermelhados, argilosos, de drenagem boa, férteis, com epipedon mólico associado a um horizonte argilico ou a um câmbico. Tais solos tem sido classificados como Podzólicos Vermelho Escuro (PE).

Em uma visão aérea da região de calcário nota-se pequenas depressões associadas ao solo PE. Exames feitos em trincheiras, nestas depressões, tem indicado 
solos morfologicamente de natureza totalmente diversa do $\mathrm{PE}$, apesar de ser aparentemente originado da mesma formação geológica. Tais solos apresentam uma sucessão de horizontes $\mathrm{Ap}, \mathrm{E}$, e Btgv com características plínticas na região de encharcamento temporário classificados como Planossolos Plínticos (PL).

Trabalhos de Pedologia, nestes tipos de solos associados são raros, principalmente relacionados especificamente ao estudo de mineralogia e gênese.

A formação de horizontes álbico por lessivagem tem sido comprovado inúmeras vezes na literatura tanto nacional como internacional (Lepsch \& Buol, 1974; Eswaran \& Sys, 1979; Buol et al., 1997). Por outro lado a formação de horizonte álbico associado à degradação parcial de horizontes $\mathrm{Bt}$ ou $\mathrm{Bw}$ tem sido pouco estudado e relatado. Demattê et al. (1995), observaram que a alteração dos Latossolos para os Podzólicos Vermelho- Amarelo e depois para Podzol em áreas de Tabuleiro no Estado de Alagoas, se deveu à ação do fluxo lateral e da redução da drenagem interna do perfil. Com isso desenvolveu-se horizontes álbicos de intensa remoção de argila e de óxidos. $\mathbf{O}$ encharcamento temporário permitiu formar o horizonte $\mathrm{E}$ remanescente do horizonte $\mathrm{Bt}$. Trabalhos similares foram feitos por Almeida et al.(1997), onde estudaram a origem do contraste textural e da degradação do topo do horizonte B de solos podzolizados no Rio Grande do Sul. Tais autores notaram que a acentuada anisotropia vertical entre horizontes era devido à saturação temporária de água nos horizontes transicionais e, portanto, devido a alternância dos processos de oxidação-redução nesses perfis.

Por outro lado quando existe uma elevada relação textural entre o A e o B, a diferença na porosidade entre os horizontes superficiais e o Bt pode causar hidromorfia, que leva à uma degradação de argilas no topo do horizonte $\mathrm{Bt}$, através da ferrólise (Brinkman, 1970). Pesquisadores no Brasil identificaram este processo que tem grande influência na formação de solos com elevado gradiente textural (Berg et al., 1987; Castro, 1989; Jimenez-Rueda \& Demattê, 1988; Vidal-Torrado et al., 1991).

A ferrólise é um processo cíclico de transformação e dissolução de minerais de argila influenciada pela redução-oxidação do Fe. Este processo era confundido anteriormente como podzolização, argiluviação ou gleização. No dicionário da ciência do solo de Lozet et al.(1991, p.102), definem a ferrólise como a "criação de 
uma condição ácida que permite a liberação e movimento do $\mathrm{Fe}$ em solução e a destruição parcial ou total dos argilominerais". A ferrólise é também observada na formação da gleização e pseudoglei; o Fe é primeiramente reduzido através de um meio orgânico em ambiente ácido, transportado e logo reoxidado, formando manchas deferrificadas e ferruginosas (Brinkman, 1970).

Camargo et al.(1987), definiram os Planossolos como sendo solos minerais com horizonte $\mathrm{Bt}$, mudança textural abrupta, conjugada com marcante transição de horizontes, originando quando seco, uma fratura de separação entre o horizonte A ou E e o horizonte subjacente $\mathrm{Bt}$, cujas cores são poucas vivas e policrômicas. As condições de alagamento, nas posições baixas do relevo nos Planossolos associados aos Brunos não cálcicos (Haplustalfs), afeta o potencial redox, que em condições reduzidas incrementa a solubilidade, lixiviação e transporte de Fe fora do sistema solo (Agbenin \& Tiessen, 1995). Ciclos repetidos de oxidação e redução aumenta os mosqueados e concreções que refletem uma distribuição não homogênea de minerais de óxido de ferro dentro do perfil (Schulze, 1989). Karathanasis \& Thompson (1995), notaram que sob condições reduzidas há aumento da mobilização do Fe e do $\mathrm{Mn}$, sendo que a dissolução do Fe foi estimulada pela formação de complexos ferro-orgânicos, através de agentes quelantes e sob condições aeróbicas.

Os principais objetivos pretendidos neste trabalho são os seguintes:

a) Detalhar os estudos pedológicos de solos de boa drenagem e de drenagem reduzida desenvolvidos de rochas da Formação Irati na região de Piracicaba;

b) Estudar as transformações pedológicas do horizonte Bt do solo PE para os horizontes E e Btv do solo PL.

Quanto a hipótese de trabalho ela pode ser resumida da seguinte maneira:

a) A formação do PL se dá no mesmo material originário do PE tendo as condições de encharcamento temporário, ocasionado pela depressão, propiciado as alterações pedológicas ai ocorridas. Neste caso a formação do horizonte álbico do PL se deve à destruição parcial ou total do horizonte argilico. Portanto a seqüência PE $\rightarrow$ PL é relevo drenagem dependente. 


\section{REVISÃO DE LITERATURA}

\subsection{Geologia e Geomorfologia: Formação Irati}

\subsubsection{Geologia}

De acordo com Ross \& Moroz (1997), a Bacia sedimentar do Paraná abrange um área de $1.600 .000 \mathrm{~km}^{2}$ e encontra-se preenchida por sedimentos na parte continental e alguns marinhos, do Siluriano Superior, Devoniano Inferior, Carbonifero Superior, Permiano, Triássico Jurássico (?) e Cretáceo. A epirogenia Cenozóica da Plataforma Sul Americana, foi o indutor para os desencadenamentos de novas formas de processos erosivos longos, com climas alternados secos e úmidos e concomitantes com o processo de epirogenia. Esses processos tectônicos e climáticos são os responsáveis pela gênese das unidades morfoesculturais: Planalto Paulista e Depressão Periférica Paulista. Durante a evolução da cadeia andina Paleozóica (Eopermiano Neopermiano), a borda sudoeste da Placa Sul Americana experimentou lento e progressivo basculamento para leste. A migração do eixo deposicional fez com que o mar, ali presente, fosse submetido a um processo de "engolfamento" no interior do continente gondwânico, e a bacia de acumulação adquirisse características de sinéclise. Devido ao confinamento esse mar Neopermiano, designado "Mar Irati", o ambiente de sedimentação foi tomado pelas condições anóxicas (inadequada oxigenação).

$\mathrm{Na}$ borda nordeste da bacia, onde a presença de sedimentos terrigenos foi muito menor, foram geradas fácies carbonáticas e sedimentação compassada, fina e esparsa do subgrupo Irati coberta por um mar euxínico (ambiente marinho pobre em 
oxigênio e rico em $\mathrm{H}_{2} \mathrm{~S}$ ) e intracontinental, que indica a mais extensiva fase de isolamento e estagnação a que foi submetida a Bacia do Paraná (Hachiro, 1997). White em 1908 propôs a "Formação Irati" FI caracterizando-a como "folhelhos pretos, geralmente petroliferos" hoje pirobetuminosos. Esses folhelhos são interestratificados com leitos irregulares de dolomitos e calcários, muitas vezes lenticulares. Concreções de sílex, de dimensões centimétricas, muitas vezes chamadas de "bonecas", foram notadas por White. Estas bonecas são muito características, inclusive em lugares onde o Irati está decomposto, associada aos solos vermelhos por serem resistentes ao intemperismo. Arenitos de granulação fina a grossa, e camadas de conglomerados ocorrem ocasionalmente na base da formação. $\mathrm{O}$ ambiente de deposição desta formação está sujeito a controvérsias, porém ela parece representar ambiente marinho de águas rasas (Suguio, 1973; IPT, 1981; Petri \& Fúlfaro, 1983). É atribuida a essa formação uma espessura entre 15 e 87 m, constituindo 4\% da área do município de Piracicaba (Ranzani et al.,1966).

O clima semi-árido à árido, da fase transgressiva deu lugar a uma alternância cíclica de forma harmônica, representada por periodos úmidos e secos. Isto estabeleceu, ao nível de sedimentação, uma estratificação tabular rítmica de grande regularidade litológica e geométrica, constituindo parte de um sistema deposicional de plataforma desenvolvido de um amplo episódio de transgressão que expandiu os limites de um mar epicontinental no Permiano Superior (Hachiro,1991). O método Rb-Sr aplicado em sedimentos argilosos em amostras paleozóicas e eo-mesozóicas das bacias sedimentares brasileiras mostram que, a FI corresponde a uma idade do PermianoSuperior (Kazaniano) uma isócrona de $180 \pm 17$ Ma (Mussa, 1982; Calero-Merino, 1989).

O Kazaniano na Russia apresenta na porção oriental, argilas e calcários com braquiópodos, provavelmente acamados em uma bacia salgada do tipo mar Caspio. O Permiano foi um período de grandes contrastes climáticos, sendo no Hemisfério Norte um clima árido ou semi-árido, evidente por apresentar camadas vermelhas e evaporitos e, no Hemisfério Sul a glaciação (iniciada ao final do Carbonífero), alcançou o seu 
clímax no Eopermiano, persistindo na Austrália até o fim do período (Leinz \& Amaral, 1975).

Através de estudos palinológicos Daemon \& Quadros (1970), concluiram que o Subgrupo Irati pertence ao que denominaram subintervalo bioestratigráfico L2, ou seja, Kazaniano. Amostras coletadas em São Paulo apresentam um espectro palinológico de formas mais jovens que foram posicionadas em um subintervalo L3, abrangendo o Kazaniano e a base do Tatariano (Neopermiano).

No território paulista a FI pode ser subordinada nos membros Taquaral (inferior) e Assistência (superior). A associação de sedimentos rudáceos e restos fósseis é um forte indício de que, ocorreram tempestades, cujas ondas mais enérgicas, além de movimentarem os clásticos mais grossos, introduziram modificações no meio ambiente que acarretaram grande mortandade de organismos sepultados junto com os sedimentos Hachiro (1991).

O Membro Assistência, atualmente com hierarquia de formação (Hachiro et al., 1993) é constituída pelos pacotes de folhelhos pretos betuminosos intercalados com dolomitos, presentes na porção superior do Irati. A designação Assistência coube a Barbosa \& Gomes (1958), que designaram como seção-tipo, as ocorrências da localidade de Assistência, entre Piracicaba e Rio Claro. Os sedimentos terrígenos, devem ter-se originado nas bordas relativamente mais elevadas dos arredores da bacia e foram carreados para às partes centrais, a partir de suas margens.

Os sedimentos carbonáticos tiveram suas áreas-fontes situados na borda oriental, onde floresceram colônias algáceas (estromatólitos). A cadência das variações climáticas e a prevalência alternada do aporte de sedimentos, ora siliciclásticos e ora carbonáticos, foram as responsáveis pela deposição das sucessões rítmicas dos pares folhelho dolomítico (Hachiro, 1997).

Segundo Leinz \& Amaral (1975), os fósseis da FI são os répteis que ganharam importância, ocupando o ambiente aquático os Mesossaurus na América do Sul e na África (Continente de Gondwana). Mesossaurus brasiliensis Mac Gregor e Stereosternum tumidum Cope e crustáceos Paulocaris e Clarkecaris; também tem sido encontrados restos de dentes de peixes Chondrichtyes e Osteichtyes, espinhos de 
nadadeira (Ctenacanthidae); coprólitos, dentes, os quais presume-se terem pertencidos à Crossopterygii ou Anthracosauria (anfibio), localizados no distrito de Assistência(Mezzalira, 1971; Ragonha, 1978).

Vasconcelos em 1973, encontrou em camadas permianas do sudoeste Goiano o reptil M. brasiliensis; e em Petrolândia novas amostras fossiliferas de calcário dolomitíco foram colhidas contendo restos de Mesossaurídeos. Os afloramentos são similares aos do Membro Assistência Irati-SP, onde o exame sugere que ditos restos pertencem a Stereosternum, mas não a Mesossaurus, destancando-se o encontro do crustácea Malacostraca, referido ao gênero Liocaris beurlen associados com restos de répteis similares aos da FI.

Neste cenário, foram os tubarões primitivos da família Xenacanthidae, os que habitaram aquele ambiente marinho-costeiro (Chondrichtyes) e os peixes cartilaginosos primitivos semelhantes às raias atuais (Itapyrodus punctatus)-Ragonha (1978). Durante o Permiano, a flora de Glossopteris da América do Sul, foi predominante com especímens de lenho fóssil existindo correlações sugestivas entre as associações lignitafoflorísticas da FI (Brasil), Barakar (Índia) e Banda Branca (África do Sul). Com respeito à FI foram reconhecidos os novos gêneros: Kraeuselpitys, Aulistoxylon, Atlanticoxylon, e Petalopitys (Mussa, 1982).

\subsubsection{Geomorfologia}

A Depressão Periférica Paulista (DPP) identificada em 1927 por Pierre Denis, foi qualificada de DPP por L.F. Moraes Rego em 1932. Essa área Paleozóica, deprimida entre as escarpas mais avançadas da zona de cuestas, que delimitam a borda oriental dos derrames basálticos (200 a $300 \mathrm{~m}$ ), e o Planalto Cristalino Atlântico, e das unidades morfológicas mais características do Estado de São Paulo; apresenta uma sucessão de rochas sedimentares de variada granulometria, formando um quadro morfológico e/ou de amplitude de horizontes e suavidade de formas, constituindo colinas de tipo aplainado entre 550 e $650 \mathrm{~m}$, levemente convexas, divisoras de vales largos, rematados em fundo chato de planícies aluviais. A pesar de dominarem os 
sedimentos paleozóicos, ocorrem áreas superficiais descontínuas de corpos intrusivos magmáticos na forma de sills e diques de diabásio que desempenham papel importante na topografia (Penteado, 1976). Segundo a mesma autora, a borda oriental da DPP, é caracterizada pela presença de uma superficie aplainada, (exemplo Campinas) ocorrida durante o início do Pleistoceno por rebaixamento e erosão areolar, provocou o recuo dos rebordos do antigo planalto neogênico até o sopé das atuais escarpas das cuestas oeste $\mathrm{e}$ norte da Bacia de Rio Claro.

Os sedimentos finos carregados para mais distante, foram depositados nas áreas centrais da bacia, em ambiente de praia ou de baixadas, exibindo estratos de argilitos variegados de 1 a $2 \mathrm{~m}$ de espessura total. Na periferia da bacia os pedimentos cortam o arenito de Botucatu e os sedimentos do Passa Dois e mesmo sills de diabásio. As colinas mais elevadas da área, circunscritas aos bordos dos interflúvios principais, nivelando a $580-590 \mathrm{~m}$, seriam provavelmente reliquiais do final daquela fase seca, posteriormente reentalhadas. Especificamente na região de ocorrência da formação Irati, o relevo é ondulado a forte ondulado com interflúvios curtos e irregulares. Ė comum um micro relevo associado, com pequenas depressões fechadas, semelhante às dolinas. Nestas depressões a drenagem regra geral é lenta e no período chuvoso o encharcamentio é temporário.

\subsection{Significado geológico da diagênese dos sedimentos}

A diagênese refere-se primariamente às reações que tem lugar dentro de um sedimento, entre minerais e os fluidos intersticiais ou supernadantes (Pettijohn, 1957). Os sedimentos não consolidados se transformam em rochas sedimentares, fenômenos fisico-químicos que agem continuamente sobre os sedimentos recém depositados e compactados pelo seu peso. Nestes sedimentos pode ocorrer a diagênese em diversas situações: (1) Os argilosos em ambientes marinhos, onde clorita e ilita são formados pela fixação de $\mathrm{Mg} \mathrm{e} \mathrm{K}$ da montmorilonita, (2) rochas carbonáticas que sofrem a dissolução, (3) a cimentação pelas algas auxiliando na litificação na gênese dos calcários de águas rasas, e (4) a matéria orgânica, que através da destruição microbiana e 
química gera matérias húmicas fossilizadas e condensados aromáticos similares ao grafito ou hidrocarbonetos parafinicos leves como o asfalto, e o material betuminoso (Suguio, 1973).

Os depósitos lacustres, refletem as trocas climáticas manifestada pela presença de carbonatos de carater biogênico incluindo carapaças de moluscos e ostrácodos e acumulações por plantas (musgos e algas). Alguns sedimentos são ricos em carbonatos brancos ou cinzentos pálidos, sendo parecidos aos depósitos de diatomáceas silíceas, podem conter fósseis de insetos e ossos de peixes, anfibios, ou pássaros (Catt, 1986).

\subsection{Gênese de solos de boa drenagem}

Acredita-se que foi Vasilii Vasirlevich Dokuchaiev em 1898, o primeiro em sugerir o conceito de solo como um corpo natural independente que está constantemente se modificando e, propos a equação dos fatores de formação do solo: $\mathrm{S}=$ $\mathrm{f}(\mathrm{cl}, \mathrm{o}, \mathrm{p}) \mathrm{t}^{\mathrm{o}}$ onde $\mathrm{S}=$ solo, $\mathrm{cl}=$ clima, $\mathrm{o}=$ organismos, $\mathrm{p}=$ material parental e $\mathrm{t}^{\mathrm{o}}=$ tempo (Gerrard, 1995). As idéias da escola russa, foram difundidas até que Hilgard \& Shaw em 1930 adicionaram o relevo (r) aos fatores de formação; culminando com a equação do fator de estado: $S=f(c l, o, p, r, t)$ de Jenny (1941). Esta equação foi modificada para ser aplicada ao pensamento moderno relacionado com os ecossistemas, ou seja $l, \mathrm{~s}, \mathrm{v}, \mathrm{a}=\mathrm{f}$ (Lo, Px, t), onde l = propriedade do ecossistema; $\mathrm{s}, \mathrm{v}$, a denotam as propriedades do solo, vegetação e animais respectivamente; Lo $=$ assembléia das propriedades no tempo zero, $\mathrm{Px}=$ fluxo de materiais e $\mathrm{t}=$ idade do sistema. Cinco amplos grupos de fatores tem sido sugeridos, entre eles: f(cl, o, r, p, t..) $\Rightarrow$ climofunção, $\mathrm{f}(\mathrm{o}, \mathrm{cl}, \mathrm{r}, \mathrm{p}, \mathrm{t} ..) \Rightarrow$ biofunção, $\mathrm{f}(\mathrm{r}, \mathrm{cl}, \mathrm{o}, \mathrm{p}, \mathrm{t} ..) \Rightarrow$ topofunção, $\mathrm{f}(\mathrm{p}, \mathrm{cl}, \mathrm{o}, \mathrm{r}, \mathrm{t}$. .) $\Rightarrow$ litofunção e $\mathrm{f}(\mathrm{t}, \mathrm{cl}, \mathrm{o}, \mathrm{r}, \mathrm{p} ..) \Rightarrow$ cronofunção.

O caminho mais conveniente de escrever uma topofunção de acordo com Jenny (1961), seria: l, s, v $=f(r)$ cl, o, p,t (Gerrard, 1995; West et al., 1988).

$O$ relevo tem um papel muito importante na gênese de solos de boa drenagem e será abordado pesquisas em ultissolos e molissolos por serem esses solos 
encontrados na catena motivo do presente estudo. O modelo Simonson (1959), da teoria geral da gênese, considera que a diferenciação de horizontes de um perfil de solo, é devido a quatro processos principais: adições, remoções, transferências e transformações de material. Por outro lado é necessário entender que os solos formam um contínuo na paisagem e que processos que ocorrem nas partes mais elevadas do relevo influenciam os solos na parte mais baixa (Hall, 1983). Enquanto o material de origem, a bioesfera e a atmosfera participam na formação do solo, o relevo se encarrega de condicionar e distribuir a matéria e energia na paisagem (Huggett, 1975); a tal ponto que solos com características morfológicas e propriedades contrastantes, convergem lateralmente e se encontram em equilíbrio sob as condições locais (Birkeland et al., 1990).

A utilidade do estudo dos solos através das toposeqüências está no reconhecimento das relações entre processos de corrosão, entre os horizontes e suas transições verticais e laterais ao longo das vertentes refletindo uma hierarquia e uma cronologia de suas propriedades. $\mathrm{O}$ resultado dos processos pedológicos e geomorfológicos são portanto a chave para o entendimento das toposeqüências (Gerrard, 1995). Tricart (1968), cita que o conceito de catena é apenas topográfico em sua origem e válido só em relação às condições de drenagem dos solos. Gerrard (1981), comenta que o conceito de catena é facilmente aplicável em áreas com uniformidade geológica, mas tem sido aplicado em áreas com geologia complexa.

Chauvel et al. (1977), enfatizaram que toda vez que a diferenciação lateral e vertical do solo é estudada, tem sido mostrado que muitas propriedades fisicas estão ordenadas no relevo, devido entre outros fatores, ao fluxo de água.

Existem muitos trabalho feitos no Brasil em solos desenvolvidos em condições de boa drenagem. De acordo com Vidal-Torrado (1994), os processos mais importantes e que levam à formação de gradiente textural entre os horizontes A e B são: migração de argilas (argiluviação) ou destruição de argilas da camada superficial, herança litológica e coluviamento. A argiluviação chamada de lessivagem por Buol et al. (1983), consiste na translocação de argilas em supensão dos horizontes A e/ou E para o horizonte B (Birkeland, 1984). É afetada pelos teores e natureza dos coloides do solo, concentração dos eletrólitos e pela atividade das argilas e o fluxo de água (Soil Survey Staff, 1975; 
Birkeland, 1984; Eswaran \& Sys, 1979; Buol et al., 1983, 1997; Nettleton, et al., 1987). Estudos de Lepsch \& Buol (1974), revelam que os solos na parte mais jovem da paisagem apresentaram o $\mathrm{Bt}$ mais desenvolvido devido ao material parental menos intemperizado e ao tempo não suficiente para organizar o plasma em estrutura granular compacta. Em outros trabalhos tais autores enfatizaram o favorescimento da mobilidade das argilas pela destruição das ligações ferro-argila (Lepsch, et al., 1977; Queiroz Neto et al., 1981).

O solos podzolizados apresentam cores variáveis, porém os horizontes B de maneira geral tem matizes entre 5YR e 7,5YR. O horizonte Bt 1 apresenta estrutura fraca a moderada e devido a tais características aliadas ao relevo mais acidentado, os riscos de erosão nestes solos são muito grandes e bem superiores aos dos latossolos (Demattê, 1988). A formação de tais solos podem ser influenciados pela drenagem, no caso de Piracicaba-SP (Demattê et al., 1991). Tais autores salientam que houve interferência da drenagem na intensidade dos ganhos e perdas dos elementos no processo do intemperismo. De maneira geral as perdas mais intensas localizadas nos sítios mais bem drenados, foram confirmados pela diminuição do indice Ki dos solos. Motta (1997), estudou a mineralogia de alguns perfis de solos localizados na região semi-árida de Ceará e resaltou que as condições de drenagem dos solos exerceram grande influência nas alterações mineralógicas. A alteração Biotita (hornblenda) $\rightarrow$ Gaulinita se deu em condições de boa drenagem e a alteração vermiculitamontmorilonita, em condições de drenagem imperfeita.

\subsection{Gênese de solos com drenagem impedida}

Demattê et al. (1992), estudaram as condições de drenagem que influenciam na morfogênese de um Typic Pelludert, solo mal drenado e um solo com drenagem moderada a boa, o Typic Argiudoll, localizado no sopé de uma vertente sobre diabásio no município de Piracicaba-SP. A drenagem limitada do vertissolo, levou-o a 
uma menor intensidade de lixiviação e intemperismo, e permitiu maior concentração de argilominerais 2:1, responsável pela grande atividade expansiva manifestada nos slickensides e na estrutura em cunha.

Os mosqueados ricos em Mn e glébulas são comuns em muito solos de drenagem impedida, sendo considerados uma evidência da flutuação do lençol freático, associados com a redução e mobilização do $\mathrm{Fe}$ e $\mathrm{Mn}$ e sua subseqüente oxidação e precipitação podendo ocorrer concreções de ferro (Ponnamperuma, 1972; Ross et al., 1976; Clothier et al., 1978). Os solos pobremente drenados apresentam tendência de serem dominados por minerais do grupo $2: 1$, enquanto que os solos melhor drenados tem uma composição mineralógica mista constiuída por esmectita, mica e caulinita. (Richards et al., 1984; Cass \& Johnston, 1985).

O termo plintita, foi introduzido pelo Soil Survey Staff (1960), definido como uma camada rica em Fe, pobre em humus misturado com argila, quartzo e outros materiais. Apresenta-se em horizontes subsuperficiais como mosqueado vermelho escuro ou avermelhado de consistência firme ou muito firme. Quanto à gênese, a plintita se forma pela segregação de ferro, importado pela mobilização, transporte e concentração final de compostos de $\mathrm{Fe}$, sob a forma de manchas vermelhas brandas, proveniente do material originário. Os mosqueados não são considerados plintitas, ao menos que tenha havido segregação suficiente de ferro, para permitir um endurecimento irreversivel quando submetido a ciclos de hidratação e dehidratação (Soil Survey Staff, 1975; EMBRAPA 1989).

Benites (1982), reporta que os Plinthic Paleudults do Perú, são desenvolvidos de sedimentos aluviais antigos ricos em argilas cauliníticas, localizados em terraços ondulados, com drenagem impedida extremadamente ácidos ( $\mathrm{pH} 4,0$ ). Demattê (1988), salienta que em solos de drenagem impedida, para a redução do Fe, não há necessidade de encharcamento prolongado. Em solos de argilas de baixa atividade na região de Ouricuri no Estado de Pernambuco, foi caracterizado material plíntico nas áreas de oscilação do lençol freático temporário, regido pelo embasamento cristalino (Ribeiro et al., 1991). Entretanto Ladeira (1995), determinou que são necessários 10.000 
anos para formar uma petroplintita de $5 \mathrm{~m}$ de espessura e muito rica em $\mathrm{Fe}(60 \%$ de $\mathrm{Fe}_{2} \mathrm{O}_{3}$ ).

Os processos químicos da formação da pirita, em ambientes alagados, envolvem redução dos íons sulfato à sulfeto através da ação das bactérias redutoras. Peiffer (1994), comprovou que a oxidação do $\mathrm{H}_{2} \mathrm{~S}$ por Fe reativo, pode contribuir para à formação da pirita. De acordo com tal autor há muitas formas de piritas a saber: singenética antiga, diagenética tardia e pirita relacionada à falha. A pirita diagenética tardia foi observada em camadas sedimentares na Formação Irati, sugerindo a origem de pós consolidação (Mirota \& Veizer, 1994).

Zhang \& Evangelou (1996), investigaram a liberação do Fe durante a oxidação da pirita, e verificaram que a formação de um recobrimento de óxidos de $\mathrm{Fe}$ associado com a sílica na superfície da pirita, pode inibir a oxidação, servindo como barreira da difusão.

\subsection{Processos específicos de gênese}

\subsubsection{Oxidação e Redução}

Os possiveis processos de formação que atuam nos solos da catena estudada são: Oxidação-redução, hidrólise, ferrólise, bioturbação, eluviação-iluviação, formação de argilomoinerais 1:1 e 2:1. Collins \& Buol (1970), acreditaram que o ciclo do $\mathrm{Mn}$ em solos, era formado através da oxidação biológica de $\mathrm{Mn}^{2+}$ à $\mathrm{Mn}^{3+}$. Os autores trabalharam em condições ácidas e observaram, que a oxidação do Fe-Mn foi lenta, houve precipitação do Fe nos valores mais baixos do Eh (faixa de $\mathrm{pH} 5,8$ a 6 ), causando a remoção do $\mathrm{Mn}^{2+}$. Hem \& Lind (1994), fizeram experimentos de titulação redox para estudar a precipitação de Mn nas águas do lençol freático contaminadas no Arizona, e encontraram alto conteúdo de $\mathrm{Ca}, \mathrm{Mg}, \mathrm{Mn}$ e $\mathrm{CO}_{2}$ dissolvidos e do $\mathrm{Mn}$ em forma de Kutahorita $\left.\{\mathrm{Mn}, \mathrm{Mg}) \mathrm{Ca}\left(\mathrm{CO}_{3}\right)\right\}$, quando o sistema foi submetido a pH 8,5 9,0 . 
Philips et al., (1998), reportaram que o Fe e o Mn ocorrem como revestimentos de poros, vesículas e canais criados pela remoção do $\mathrm{CO}_{3}$ do saprólito, cujo movimento da água é influenciado pelas posições da paisagem. Daniels et al.(1961), verificaram que os sedimentos com cores $2,5 \mathrm{Y}$ e $5 \mathrm{Y}$ tem baixo conteúdo de $\mathrm{Fe}$ ferroso. Perfil.

Nestas condições, pode-se encontrar horizontes $\mathrm{Cg}$ em solos saturados, e minerais sulfurêtos como as piritas podem se formar. Tais materiais estão expostos à oxidação do $\mathrm{Fe}$ devido à formação do $\mathrm{H}_{2} \mathrm{SO}_{4}$ durante a oxidação de sulfetos.

A jarosita se forma numa faixa de $\mathrm{pH}$ de 3,5 a 4,0 sendo relativamente estável aos óxidos de Fe (Fanning \& Fanning, 1989). Gotoh \& Patrick Jr. (1974), estudaram as formas de Fe em solos alagados e reportaram, que o aumento do Fe solúvel em água $\left(\mathrm{Fe}^{2 \dagger}\right)$ e $\mathrm{Fe}$ trocável foram favorecidos pela diminuição do potencial rédox. A ativitividade do $\mathrm{Fe}^{2+}$ em solos inundados pode ser governada pela solubilidade do oxihidróxido férrico (Atta et al., 1996).

A cor dos solos está relacionada aos óxidos/hidróxidos de $\mathrm{Fe}$, à susceptibilidade magnética, ao uso agrícola e às condições climáticas do solo (Resende, 1976; Kämpf \& Schwertmann, 1983; Camargo et al., 1987). Ela é reconhecida como uma das características mais importantes do perfil do solo, utilizada para a descrição e classificação dos solos (Soil Survey Staff, 1975 p.463). Jacks em 1934, observou que a cor vermelha dos solos tropicais, era devida a um baixo conteúdo de humus e alto grau de oxidação do ferro. Muitos nomes populares de solos são dados em função da cor e reconhecidos universalmente como: Terra Roxa, Terra Preta e Sangue-de-Tatú. Também designa muitos nomes de classes do sistema de classificação pedológica atualmente em desenvolvimento e em uso no Brasil, tais como Podzólico Vermelho Amarelo (PV), Podzólico Vermelho Escuro (PE), Latossolo Roxo (LR), Hidromórfico Cinzento (HC) (Lepsch, 1992; Oliveira et al., 1992).

Os diversos matizes, entre eles o vermelho, amarelo, pardo e os mosqueados vermelho e as cores brancas, são o resultado do intemperismo prévio ou não à formação do solo. A hematita $(\mathrm{Hm})$ é responsável pela cor vermelha e domina nos solos bem drenados; a gohetita (Gt) pela cor amarela; a maghemita (Mh) pela cor pardo 
escura variando de amarelo para vermelho-escuro. As terras amareladas e cinzentas estão associadas com o lençol freático, enquanto que as vermelhas ocorrem em situações de boa drenagem (Resende, 1976; Duchaufour, 1982; Kämpf \& Scherwertmann, 1983) ). Em condições tropicais os solos oxidados resultam na cor vermelha, enquanto que a gleização causa matizes ocre ou cinzento-azulado (Sokolov, 1997; Buol et al.,1997).

Os compostos de óxidos de $\mathrm{Fe}$ mais hidratados (gohetita e limonita) são amarelados, enquanto que os hidratados (hematita) são avermelhados ou tornanam-se vermelho-brilhante à roxo-purpúreo (5YR) ou mais vermelho (Karmanova, 1981; Schwertmann, 1989). Solos com matizes de 7,5 a $5 Y R$ e os mais vermelhos, devem sua cor à hematita e os mais amarelados a gohetita (Schwertmann et al., 1982).

O grau de avermelhamento dos solos da Europa (alfissolos) e do Brasil (oxissolos), baseados em medidas da cor visuais e espectrofotométrica, foram determinadas por Torrent et al. (1983). Os autores encontraram que a gohetita é bruno amarelado (10YR a 2,5Y); a hematita é vermelha (7,5YR e mais vermelha); ferrhidrita (bruno-avermelhado) e a lepidocrocita da cor laranja. Mesmo assim, eles observaram que ao adicionar somente $1 \%$ de $\mathrm{Hm}$ a uma mistura contendo caulinita, quartzo, biotita , feldspato-K, e 3\% de Gt, causou uma mudança na matiz de 2Y para $5 Y R$.

\subsubsection{Hidrólise}

Melfi et al. (1979), reportaram que no Brasil a hidrólise é o principal mecanismo que atua na alteração superficial das rochas; podendo o $\mathrm{Fe}$ sofrer uma acumulação generalizada e atingindo valores bem elevados ( $>35 \%)$. Em condições de oxidação o Fe permanece no meio de alteração incrementando-se em relação ao material parental. Ao contrario, um forte ataque acidolítico ou uma evolução no meio redutor, provoca a mobilização do $\mathrm{Fe}$ e facilita a sua distribuição no perfil Quando ao $\mathrm{Si}, \mathrm{Al}, \mathrm{Na}$ ou K são liberados num sistema bem drenado (Melfi \& Pedro, 1977).

A hidrólise do alumínio, ocorre quando os íons $\mathrm{Al}$ trocáveis de radicais ácidos ao se neutralizar num $\mathrm{pH} 4$ a 5,5 (ions monomêricos), se apresentam na solução em forma hidratada com seis moléculas de água e reagem em várias etapas. $\mathrm{O}$ produto 
final das reações é um óxido de alumínio amorfo que ao perder água de hidratação forma a gibbsita $(\mathrm{Gb})$ ou hidrargilita.

Com precipitações na faixa de 1400 a $2500 \mathrm{~mm}$ na região norte do Rio de Janeiro, Moniz et al. (1990), caracterizaram os solos gibbsíticos formados a partir de rochas alcalinas e gnaisse. Quando a precipitação foi inferior a $1400 \mathrm{~mm}$, os solos eram cauliníticos e sem gibbsita; e em precipitação menor que $1000 \mathrm{~mm}$ além da caulinita, ocorre minerais 2:1. A gibbsita, é o hodróxido mineral de Al mais comum nos solos, associado com a última etapa do intemperismo, encontrando-se normalmente nos oxissolos de regiões tropicais (Schulze, 1989).

Segundo Eswaran et al. (1977), a Gênese da gibbsita não pode ser explicada facilmente nos solos mas, outros pesquisadores sugerem a transformação da Biotita $\rightarrow$ Gibbsita através das quebraduras de aluminosilicatos secundários como também a Caulinita $\rightarrow$ Gibbsita. Para Möller \& Klamt (1983), a gibbsita se forma pela cristalização da camada aluminosa-amorfa quando o teor de Si da solução dos solos está baixo, que no caso de um Typic Haplorthox, os argilominerais sofreram a transformação da seqüência Mica $\rightarrow$ Vermiculita cloritizada $\rightarrow$ Gibbsita.

\subsubsection{Ferrólise (Destruição de argilominerais)}

Gerasinova (1981), observou que nos solos podzólicos, a superfiicie gleizada promove o movimento descendente dos constituintes do solo devido à destruição dos minerais na sua parte superior. As transformações físico-químicas que ai se processam inclue a desestabilização da estrutura do solo, pedoturbação, alteração do $\mathrm{pH}$, dissolução de minerais e síntese. Em solos de várzeas (Rio Ribeira-Iguapé, SP), os fatores que influenciam na formação de solos, estão ligados à intensidade de oxiredução- ferrólise (Berg et al., 1987). 


\subsubsection{Bioturbação}

A bioturbação (Gk. Bios, vida; L. turbatio, perturbação) é definida como a series de perturbações em um sedimento ou solo devido à ação dos organismos: (Lozet et al., 1991 p.34). Em contraste com os cinco fatores de formação de solos, Hole (1961) propôs o termo pedoturbação como a mistura de solos pelos animais. Em solos florestais, com textura média a argilosa estima-se que 500 a 2500 ton. Acre ${ }^{-1}$ de solo têm sido modificado pelas minhocas (Thorp, 1967). As formigas, em Wisconsin, moveram para a superficie o equivalente a $25 \%$ da camada arável, reduzindo a densidade do solo de 1,5 para $0,8 \mathrm{~g} . \mathrm{cm}^{-3}$ (Salem \& Hole, 1968). Minhocas e térmitas influenciam os ecossistemas tropicais; as primeiras estão reduzidas à regiões com precipitação $>800$ mm, as térmitas, vivem em condições muito mais secas. Os macrovertebrados são agentes eficientes na conservação da fertilidade do solo e tem seu efeito também na estrutura formando agregados e aumentando a porosidade. Minhocas (endogênicas), podem ingerir de 5 a 30 vezes seu próprio peso em solos (Lavelle et al., 1992).

Antony (1997), investigou a fauna do solo em ecossistemas amazônicos e verificou que entre sistemas naturais, a maior abundância de invertebrados foi observada em solos Gley Pouco Húmico, com uma média de 116.409 individuos. $\mathrm{m}^{-2}$ na camada de 0 a $10 \mathrm{~cm}$, elevada para solos amazônicos seguida dos Podzóis com 115.332 individuos. $\mathrm{m}^{-2}$. Doran et al. (1996), reportaram que $10 \mathrm{~g}$ de solo fertil pode ter mais de 9 bilhões de organismos viventes, quase o dobro da população mundial. Calero-Merino (1987), em regiões tropicais temperadas no norte do Perú, notou que a atividade faunal é dominada pelos anélidos da ordem Opisthospora (minhocas), oligoquetas terrícolas de tamanho relativamente grande (megadril) e os enquitreidos (fam. Enchytridae), atingindo mais de $80 \mathrm{~kg} \cdot \mathrm{há}^{-1}$ de biomassa. $\mathrm{O}$ autor também relatou que as vespas da familia Hallictidae, constróem "silbatos", cuja feição bioturbada, sugere a presença de um Bt nos alfisolos e ultissolos nestas regiões. Tan (1994) revela que sob florestas tropicais na Nigeria, as minhocas têm uma população na faixa de 30 a 210 individuos. $\mathrm{m}^{-2}$, estimando-se uma atividade de renovação de $21,5 \mathrm{Mg}$ (ton.) há ${ }^{-1}$. Ano ${ }^{-1}$. 
Nos Cerrados Brasileiros, as saúvas constroem formigueiros de até $10 \mathrm{~m}$ de diâmetro por $1 \mathrm{~m}$ de altura com até dois milhões de formigas e com uma logevidade cerca de 15 anos (Vargas \& Hungria, 1997).

\subsubsection{Eluviação- Iluviação (Lessivagem) e Gênese do horizonte Álbico (E)}

Ranney \& Beatty (1969), verificaram que em solos com horizonte álbico, como os Glossoboralfs de Wisconsin, as línguas de penetração podem ter sido formadas por eluviação de argila em suspensão, sem destruição da estrutura cristalina (lessivagem), com perda de sílica e acumulação na zona eluvial formando um horizonte $\mathrm{A}_{2}$ (Álbico, L. albus, branco). EMBRAPA (1981, p.43), define o álbico como um horizonte mineral subsuperficial, no qual a remoção ou segregação de material coloidal inorgânico e orgânico progrediu a tal ponto que a cor do horizonte é determinada mais pela cor das partículas primárias, de areia e silte, mais do que pelos revestimentos nessas partículas. $\mathrm{O}$ "value" é maior ou igual a 4 no estado estado úmido e maior ou igual a 5 no estado seco. Vepraskas \& Wilding (1983), sugerem que os neoeskeletãs álbicos podem ser utilizados como critério diagnóstico de saturação d'água e redução de $\mathrm{Fe}$, permitindo identificar os intergrades "aquic" nos Paleudalfs.

Alguns autores o consideram como um horizonte de amorfização biogênica (perda da forma produzida pela ação de organismos viventes) de minerais de argila e intemperismo de minerais das frações grosseiras, incluindo os bleicherde (horizonte embranquecido na Alemanha) dos podzols, e o horizonte A2 embranquecido dos planossolos (Vieira, L. \& Vieira, 1983; Soil Survey Staff, 1990; Sokolov, 1997). Na Nova Zelândia, Laffan et al.(1986), mostraram que as características típicas dos horizontes eluviais e iluviais foram devidas à podzolização.

Cerca de $80 \%$ da Bacia Amazônica é coberta por espessas camadas lateríticas, consideradas em contínua evolução buscando o equilibrio pedobiológico. Nos solos argilosos verifica-se a hidrólises (dissolução), resultando em perdas de sílica por drenagem vertical profunda e acúmulo de Fe e Al (ferralitização). Essa perda de matéria, estimada por balanços geoquímicos no perfil, tem provocado um rebaixamento 
da superficie da ordem de 0,001 a $0,002 \mathrm{~mm}^{-a n o^{-1}}$. A existência de um fluxo hídrico lateral, resulta na perda de $\mathrm{Si}$ e Fe nas soluções de alteração, caracterizando o processo de podzolização (Melfi et al., 1979; Ab'saber, 1996). De acordo com Nettleton et al. (1975), o horizonte Bt dos solos de Nevada, foram formados pela translocação de argilas, manifesta também por acumulação de $\mathrm{Al}_{2} \mathrm{O}_{3}$ e $\mathrm{Fe}_{2} \mathrm{O}_{3}$.

O termo argilãs foi introduzido por Brewer (1964), para descrever os revestimentos de argila aluminosilicatada translocadas e depositadas nas paredes dos agregados e canais. Em nicóis cruzados os argilãs mostram características de coloides cristalinos iluviais de argila e óxidos de Fe. Nettleton et al. (1987), destacaram que a translocação de argila, é um processo pedogenético importante na formação dos ultissolos da California, Hawai e Porto Rico. Moniz (1996), salienta que o processo de argiluviação, por si só, não é suficiente para explicar a formação de horizontes Bt a partir de horizontes $\mathrm{Bw}$. $\mathrm{O}$ conceito de adensamento por dessecação com transformações laterais condicionadas pela dinâmica dos fluxos de água lateral e basal, permite a elaboração de modelos de gênese de solos com $\mathrm{Bt}$ a partir da transição $\mathrm{Bw} \rightarrow \mathrm{Bt}$ freqüentemente observados no Brasil.

Karmanova (1981), afirma que o horizonte álbico é o resultado de muitos processos de formação do solo, porém o processo mais evidente é o de remoção do ferro, como resultado da dissolução, ou segregação. Dechen et al. (1994). estudaram três solos podzolizados originados do arenito da Formação Marília no Estado se São Paulo, salientaram que "o processo de translocação do material foi o mais evidente e comum na formação dos perfis, evidenciado pela formação dos horizontes B textural e álbico. Além disso a fração argila mostrou o processo de iluviação, manifestada pelo aumento dos teores de argila nos horizontes Bt e diminuição nos horizontes de perda".

O estudo da gênese do Bt tem sido objeto de muitos trabalhos executados por pesquisadores em regiões tropicais e temperadas. $\mathrm{O}$ principal processo neste caso foi designado de lessivagem ou argiluviação como sendo a migração de argila dos horizontes superficiais e posterior acúmulo no horizonte $\mathrm{B}$, causando o desenvolvimento de cutãs (Buol et al.,1983, 1997; Tan, 1994; West et al., 1988). Birkeland (1984); considerou três processos para a formação do $\mathrm{Bt}$ : o primeiro seria a formação e 
acumulação de argila no próprio local "in situ", através da alteração de minerais primários; o segundo seria a translocação descendente do material em solução e nova formação da argila; o terceiro o transporte das argilas em suspensão na água de percolação e posterior deposição no $\mathrm{B}$, devido à floculação ou diminuição dos poros por onde a água se movimenta.

Jimenez-Rueda \& Demattê (1988), estudaram os solos da formação Marilia, desenvolvidos "in situ" de arenitos grosseiros e conglomeráticos, disseminados em uma massa carbonatada, observaram que os $\mathrm{Bt}$ dos perfis são originados do material lamítico, de natureza argilosa, e o acentuado gradiente textural, deve-se em parte ao processo de "degradação do horizonte B textural" ocasionado pela remoção lateral e/ou destruição das argilas e não por lessivagem.

Perecin \& Ferraz (1975), estudando sete perfis de solos em Piracicaba, através de seções delgadas encontraram nos $\mathrm{Bt}$, argila iluvial depositada sobre a fábrica intertéxtica, preenchendo os poros, transformando aquela fábrica em porfiroesquélica, passagem gradual das características do Bt para Bw. Moniz \& Buol (1982), desenvolveram um modelo para explicar a formação da estrutura dos solos durante seu desenvolvimento, destacando que os ultissolos formam-se de materiais óxídicos através do fluxo lateral e basal integrado na paisagem. A hipótese da formação do $\mathrm{Bt}$ dos ultissolos a partir dos oxissolos pode ocorrer devido à saturação $\leftrightarrow$ dessecação $\rightarrow$ compressão dos agregados induzido pelo fluxo de água. A formação da camada comprimida é controlada pelo relevo, que promove a formação de um fluxo lateral d'água, a medida que o relevo chega a ser mais profundo, assim como pelo grau de anisotropia textural vertical. Vidal-Torrado \& Lepsch, (1993), sugerem que, a formação do Bt, deve-se à ação conjunta do adensamento crescente do topo para o sopé, provavelmente provocado pelo fluxo hídrico lateral subsuperficial, e do aumento gradativo das melhores condições para a argiluviação, que é favorecida a partir do ombro da vertente, tendo sua expressão máxima no sopé, onde o material de origem é menos intemperizado. Em uma seqüência de solos de Piracicaba, Cooper (1996) mostrou que a evolução estrutural de um horizonte $\mathrm{Bw}$ para um $\mathrm{Bt}$, foi devida a um adensamento do horizonte $\mathrm{Bw}$, pela coalescência dos microagregados durante um periodo de clima 
mais seco que o atual, e que provocaria tensões pelos ciclos alternados de umedecimento e dessecação, resultando na fissuração do material e a formação de microagregados poliédricos. Os microagregados dos latossolos, são originados pelos processos de zoogênese, desferrificação parcial, estruturação e a formação de agregados complexos (Silva, 1997); ou podem contribuir processos dinâmicos causados pelo adensamento e ciclos de dessecação, manifestada por uma porosidade que aumenta de cavitária para fissural, uma assembléia de microagregados delimitados por fissuras e cavidades policóncavas, que envolvem os microagregados, evidenciando um horizonte B em processo de latossolização (Calero-Merino et al., 1997, 1998).

Moniz et al. (1994), notaram que a transformação de uma estrutura granular em estrutura em blocos em Terra Roxa, é um processo remontante ao longo da vertente em Rio Das Pedras, induzido pela existência do fluxo lateral d'agua.

\subsubsection{Mineralogia da argila: dessilicatização}

Demattê (1968), encontrou em solos podzolizados de Piracicaba (PV), que o teor de ilita na fração argila grossa, é sempre maior do que $10 \%$, sendo que, em certos horizontes apresentaram teores de $30 \%$ até $40 \%$. A montmorilonita e os minerais de $14 \mathrm{~A}^{\circ}$ ocorrem normalmente com valores inferiores a $10 \%$. A caulinta é o mineral dominante nas duas frações argila, com teores superiores à $40 \%$. Melfi et al. (1983) verificaram que o mineral mais abundante foi a caulinita, como resultado do intemperismo do feldspato. De acordo com Karathanasis et al. (1983) nos ultissolos, a mineralogia da fração argila consistiu de 22 a $60 \%$ de caulinita, 0 a 20\% de gibbsita, 17 a 57\% de vermiculita-hidroxi-intercamadas (HIV), e de 1 a 12\% de quartzo. Quanto a possível gênese dos argilominerais 1:1, muitos cientistas sugerem alguns caminhos sendo os principais:

Mica (muscovita) $\rightarrow$ Caulinita (Ahmad \& Jones, 1969); Folhelho (mica) $\rightarrow$ Vermiculita $\rightarrow$ Caulinita $\rightarrow$ Gibbsita (Demattê, 1970; Demattê, et al., 1977); Feldspato $\rightarrow$ Caulinita (Allen \& Hajek, 1989; Melfi et al., 1983); Mica $\rightarrow$ Vermiculita $\rightarrow$ Caulinita $\rightarrow$ Gibbsita (Escobar et al., 1973); Oligoclasa $\rightarrow$ Caulinita (Inskeep et al., 
1993); Feldspato $\rightarrow$ Gibsita $\rightarrow$ Caulinita, Piroxênios $\rightarrow$ Goethita e Hemattita (FitzPatrick, 1993); Hidrobiotita $\rightarrow$ Vermiculita ( Robinson \& Williams, 1994); Biotita $\rightarrow$ Caulinita, Halloisita (Kretzschmar et al., 1997).

Em condições acídicas e em solos bem drenados associado a climas quentes e úmidos, nas posicões antigas da paisagem, a caulinita pode ser herdada de sedimentos ácidos (Dixon, 1989). Rotta (1975), estudou a mineralogia dos solos de Atibaia-SP, e revelou que a caulinita era predominante (45 a 85\%) e que nos podzólicos as variações em profundidade foram mais acentuadas que no caso dos latossolos. Da mesma forma Tremocoldi \& Steinhardt, (1987), encontraram que nos solos com Bt de Pindorama-SP, predomina a caulinita, seguida por mica, anatásio e traços de minerais interestratificados. Argilãs e ferriargilãs ocorrem no horizonte $\mathrm{B}$, evidenciando iluviação de partículas finas para as acamadas inferiores dos perfis.

Na região de São Pedro-SP a mineralogia da fração argila, em solos formados nas superficies mais jovens é formado por um teor baixo de gibbsita $(<6 \%)$ e elevado de caulinita (74\%), enquanto que os solos das altas superficies mais velhas, possuem de 12 a $54 \%$ de gibbsita e 26 a $71 \%$ de caulinita (Demattê \& Holowaychuck, 1977). Kämpf \& Klamt (1978), estudaram a mineralogia dos ultissolos da região nordeste do Planalto Sul-Riograndense, e notaram predomínio da Caulinita/haloisita, materiais amorfos e óxidos livres; ocorrendo em menor proporção argilominerais 2:1 cloritizados, gibbsita, quartzo, cristobalita e plagioclásios.

Os solos tropicais altamente intemperizados, têm aparentemente uma mineralogia similar (silicatos laminares $1: 1$, óxidos de $\mathrm{Fe}$ ). Um exame mais específico destes minerais, indicou que a caulinita nestes solos difere entre si pelo tamanho, pela área superficial, CTC e conteúdo de ferro (Schwertmann \& Herbillon, 1992). Demattê et al. (1995), estudando a gênese de uma toposeqüência oxissolo-ultissolo em Maceió observaram que no perfil do oxissolo de melhor drenagem, a dessilicatização é mais intensa e a tendência é a formação de minerais menos ativos como a caulinita, que domina com pouca contribuição de gibbsita. Tais autores observaram ainda que a medida que a drenagem vai ficando mais restrita, a hidrólise é parcial, e a tendência é uma dessilicatição intermediária ou monossilicatização, com dominância de caulinita 
passando para uma bissilicatização nos perfis de drenagem mais restrita com ocorrência de minerais $2: 1$, no caso micas e os interestratificados.

Muitos trabalhos têm sido dedicados para desenvolver a gênese dos argilominerais 2:1 a partir de minerais primários entre eles destacam-se os seguintes: Piroxênio $\rightarrow$ Esmectita e Goethita (Clemente, 1988); Mica $\rightarrow$ Vermiculita $\rightarrow$ Montmorilonita (Cady, 1967; Douglas, 1989); Ilita $\rightarrow$ Vermiculita $\rightarrow$ Montmorilonita (Smeck et al.,1968); Plagioclásio $\rightarrow$ Esmectita (Verstraten \& Sevink, 1979); Biotita $\rightarrow$ Vermiculita, Mica-Vermiculita $\rightarrow$ Vermiculita (Shoba \& Sokolova,1981); Esmectita $\rightarrow$ Clorita intergrado, Haloisita (Glasmann \& Simonson, 1985); Clorita $\rightarrow$ CloritaVermiculita e Esmectita, Hornblenda $\rightarrow$ Esmectita e gohetita; Feldspato (Pg-Ca) $\rightarrow$ Caulinita (Rice et al., 1985); Muscovita $\rightarrow$ Esmectita, Biotita $\rightarrow$ Montmorilonita (Aoudjit et al.,1995); Mica (muscovita) $\rightarrow$ Vermiculita-hidroxi-intercamada (Wesemael, et al., 1995); Vermiculita $\rightarrow$ Esmectita, Serpentina $\rightarrow$ Esmectita (Bonifacio et al.,1997); Esmectita (ilitização) $\rightarrow$ Ilita (Clauer et al.,1997); Ilita $\rightarrow$ Vermiculita-Ilita interestratificados (Fichter, et al.,1998).

Na Carolina do Norte, Weed \& Nelson (1962), encontraram cloritaintergrado e com caulinita, sendo que a mica foi o precursor dos intergrades. Os argilominerais 2:2, são formados pelo acúmulo de hidróxidos de aluminio nas entrecamadas dos filossilicatos expansivos (Kämpf \& Klamt, 1978). Jungerius \& Levelt (1963), estudaram os solos do leste da Nigeria e verificaram que a montmorilonita e ilita foram encontradas em condições de drenagem pobre.

Lima et al. (1977), estudaram a mineralogia das argilas dos Rubrozem (Palehumult) da Bacia de Curitiba-Paraná, revelaram que a caulinita era dominante (40\%), seguida da montmorilonita (21\%), mica (20\%), vermiculita (10\%), alofana (6\%) e gibbsita (3\%). Os estudos de Volkoff et al. (1989), na região do Alto Purus (Estado do Acre), ao comparar Cambissolos e um PV, demostraram que os solos são desenvolvidos a partir de um material argiloso rico em esmectita de alta carga, associados à ilitas e poucas caulinitas. Para Moniz et al. (1995), o material de origem dos solos da região de Piracicaba-SP, são produto da alteração de arenitos, folhelhos, siltitos, rochas básicas e 
sedimentos pleistocênicos das planícies aluviais. Esses sedimentos pertencem aos grupos Tubarão, Passa Dois e São Bento. Borchardt (1989), reporta que a maioria das esmectitas são estáveis em solos de pH neutros, ambientes pobremente drenados, e de lixiviação restrita da sílica e das bases.

Quanto à gênese das esmectitas, Jongmans et al. (1998), indicaram que pode se distinguir dois caminhos de formação das esmectitas: seria a formação da esmectita pela perda de íons das estruturas silicatadas existentes, tal como a mica e a clorita e, segundo, a esmectita neogênica formada pelos ions precipitados diretamente da solução. A gênese dos argilominerais 2:1, está associada à condições de elevada relação Si/Al, abundância de bases e, baixa concentração de ions $\mathrm{H}^{+}$(Lima et al.,1977); ou pode ser formada como uma fase intermediária e não estável em condições de elevado intemperismo na zona do saprólito (Schölten et al.,1997).

Em condições de $\mathrm{pH}$ neutro à alcalino, alto nivel de bases e drenagem restrita nos Aquolls, foi formado um ambiente ideal para à neoformação das espécies esmectíticas (Borchardt, 1989). Jongmans et al. (1994), determinaram a herança dos filossilicatos 2:1 em Hapludands (Andissolos de regime udic) holocenicos e arenitos andesíticos da Costa Rica. Tais autores observaram que a alteração hidrotermal de minerais primários em filossilicatos 2:1, foi o processo responsável pela formação dos solos derivados das rochas vulcânicas. Clauer et al .(1997), fizeram na França estudos mineralógicos, geoquímicos e isotópicos $\left(\mathrm{K}-\mathrm{Ar}, \mathrm{Rb}-\mathrm{Sr}\right.$, e $\left.\delta{ }^{18}\right)$ de argila e encontraram que os minerais tipo ilita estão incluídos numa mistura ilita/esmectita no topo da seqüência e, a mica (ilita) no sopé.

Krasi'lnikov (1997), notou que a transformação de filossilicatos nos solos adjacentes, está condicionada pela degradação e ruptura das grades, onde as micas e cloritas perdem $\mathrm{Fe}, \mathrm{Mg}$ e algumas vezes $\mathrm{Al}$, dando camadas minerais pobremente ordenadas. $\mathrm{O} F e$ na fase líquida pode participar das reações de troca com o $\mathrm{Mg}$ na posição octaedral da saponita. Esta suposição tem sido baseada no fato de que o $\mathrm{Fe}$ participa na formação da pirita durante a sedimentação ou transformação da rocha sedimentar. 


\section{MATERIAL E MÉTODOS}

\subsection{Caracterização do meio físico}

\subsubsection{Localização}

A área estudada fica localizada nas proximidades do Arraial de São Bento, no município de Saltinho, próximo a Piracicaba, Estado de São Paulo, entre as coordenadas $22^{\circ} 55^{\prime}$ de latitude Sul e $47^{\circ} 43^{\prime}$ de longitude Oeste (W Gr.). Na rodovia entre Piracicaba- Tietê, aproximadamente no km 60, há uma estrada vicinal a direita em direção ao distrito de Bairrinho (Figura 3.1). Nos arredores deste distrito há ocorrência de diversas exposições de calcário. Após varias excursões a esta região selecionou-se para a realização deste trabalho, a sucessão de perfis localizados na "caieira" designada como "Teixeira".

O local escolhido é constituido por ter relevo ondulado a forte ondulado, associado à depressões normalmente circulares. Num transecto de $180 \mathrm{~m}$ foram abertas 4 trincheiras indo da trincheira de melhor drenagem, designado como $\mathrm{T} 1$, até a trincheira de menor drenagem, designado como T4, no centro da depressão. As trincheiras T2 e T3 são intermediárias (Figura 3.2). 


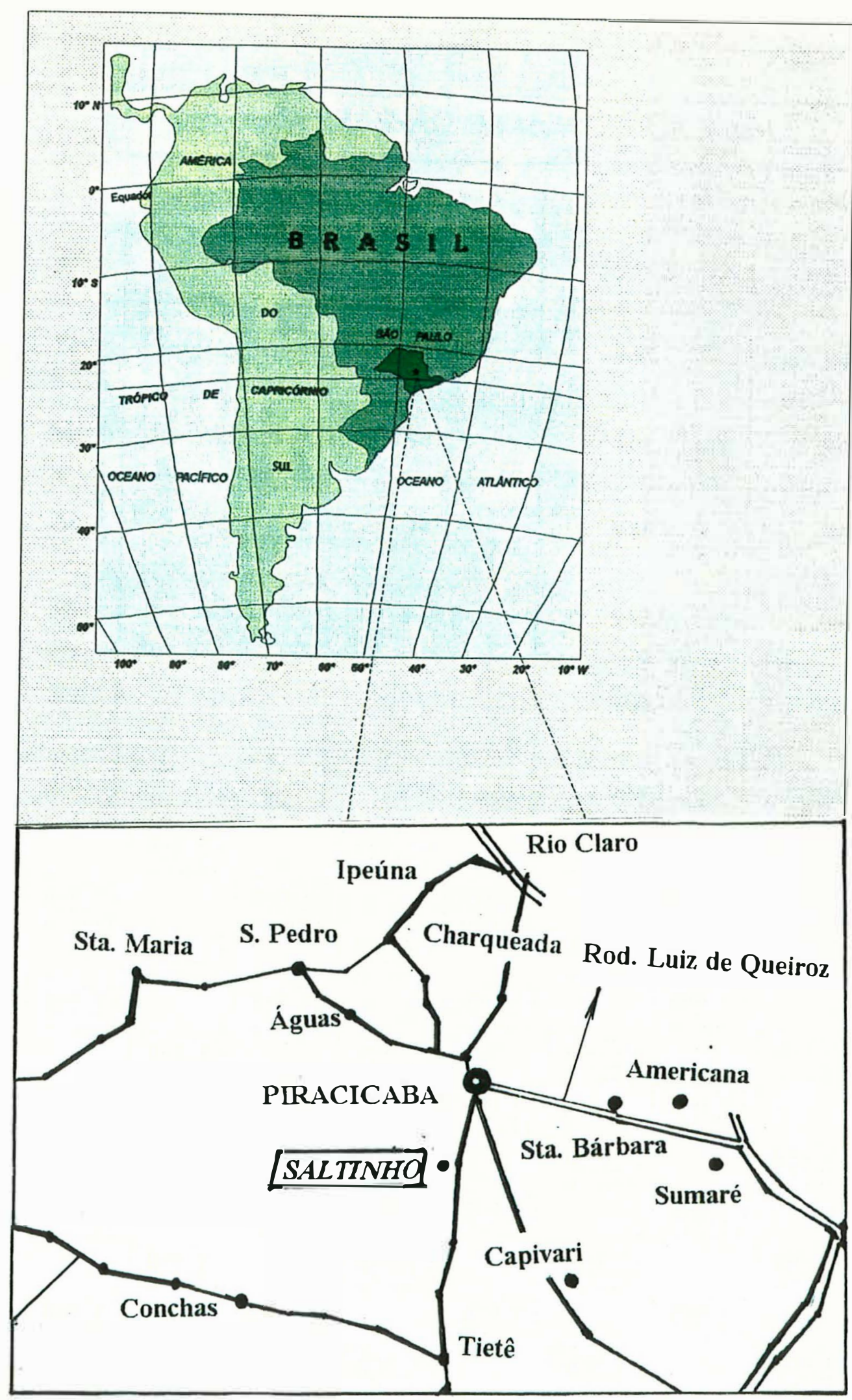

Figura 3.1. Localização da área de estudo no município de Saltinho no Estado de São Paulo 


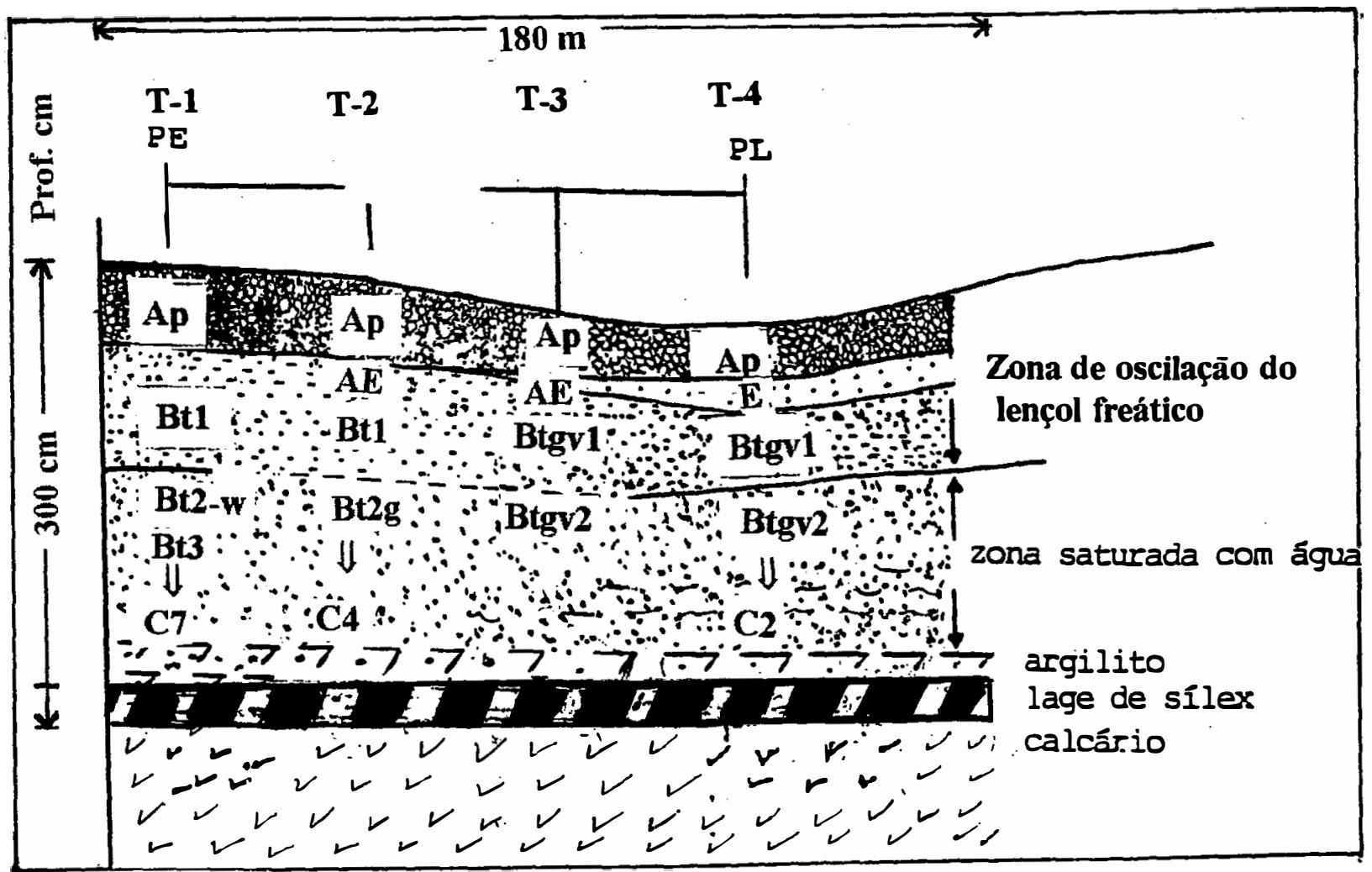

Figura 3.2. Esquema (sem escala) ilustrando a posição dos perfis $T-1$ ao $T+$ este na depressão assim como a sequência dos horizontes. A oscilação do lençol freático não atinge o T-1. 


\subsubsection{Geologia}

As principais unidades litoestratigráficas da área formaram-se durante o período do Permiano Superior da Era Paleozóica, entre 251 e 230 milhões de anos atrás, correspondentes ao Grupo Passa Dois, Formação Irati, Membro Assistência (IPT, 1981). A Formação Irati, está composta por siltitos, argilitos e folhelhos silticos de cor cinza clara a escura, folhelhos pirobetuminosos. Localmente tais rochas foram uma alternância rítmica com calcários creme silicificados e restritos níveis conglomeráticos. A Figura 3.3. indica esta sequência no local de estudo na "Caieira Teixeira" e a Figura 3.4. ilustra as formações geológicas da região estudada. As análises do calcário da região indicaram ser dolomítico.

\subsubsection{Geomorfologia}

De acordo com IPT (1981) a área de estudo está localizada na Depressão Periférica Paulista, pertencente a depressão do Médio Tietê, Esta zona compreende a área que é drenada para o rio Tietê, segundo os divisores de águas dos rios Mogi-Guaçu e Paranapanema. É constituída por sedimentos com superficie expressiva de intrusões de rochas básicas. A inclinação das camadas sedimentares fez com que se destacassem, sob formas de cuestas, as rochas sedimentares da Formação Irati, de variada granulometria. $\mathrm{O}$ relevo é ondulado a forte ondulado com micro depressões similares às dolinas e estruturas silicificadas da Formação Corumbataí (Penteado, 1976; IPT, 1981; Ross \& Moroz, 1997).

\subsubsection{Clima}

O clima da região de Piracicaba, é classificado no sistema Köppen Cwa, mesotérmico úmido subtropical de inverno seco. A tabela 3.1 resume os dados do balanço hídrico no período 1917-1996. Segundo os dados da Tabela 3.2, a média da temperatura dos meses mais frios (Maio- Ago) é de $18,3^{\circ} \mathrm{C}$ e a dos meses mais quentes 

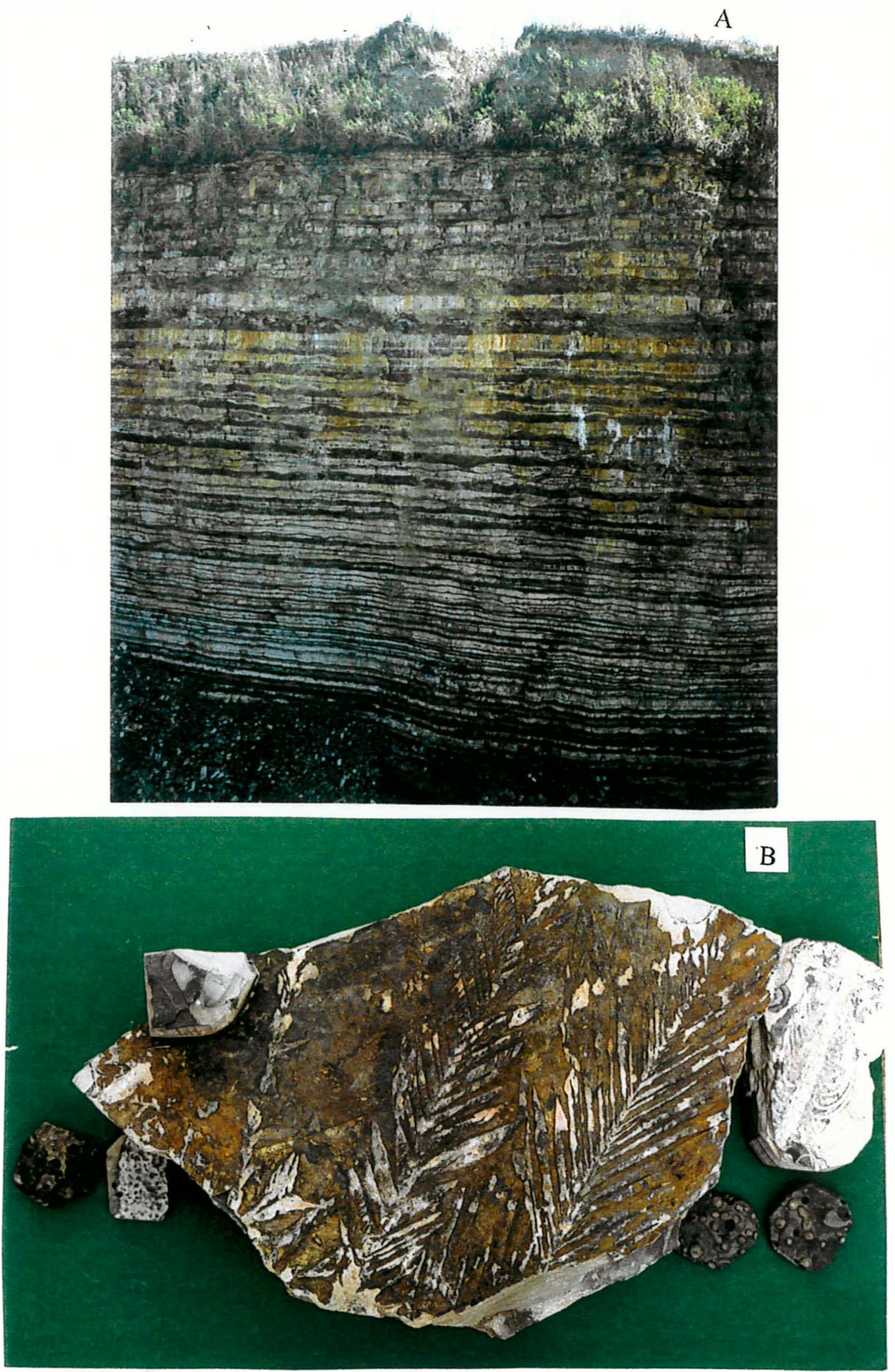

Figura 3.3. Sequência estratigráfica da Formação Irati-Membro Assistência. (A) Exposição de ritmitos nos estratos na Pedreira do calcário "Teixeira" a $5 \mathrm{~m}$ da catena Saltinho (SP). (B) Fósseis de Pteridofitas e Mesossaurídeos Permianos (Kazaniano). 


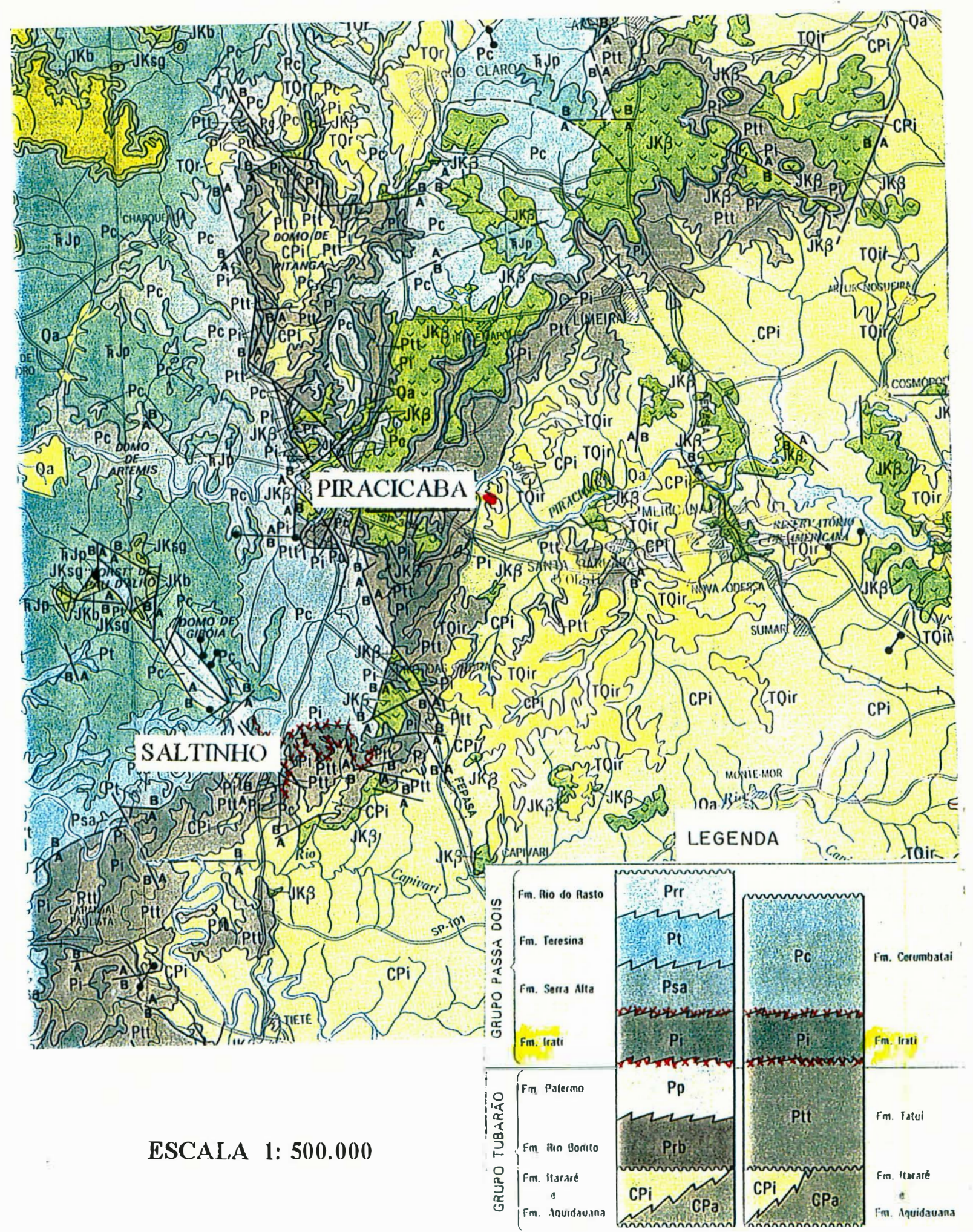

Figura 3.4. Mapa Geológico da cuadrícula indicando o municipio de Saltinho que foi a área estudada. Fonte: IPT (1981). 
Tabela 3.1. Balanço hídrico Thornthwaite-Mather (1955)

Local: Piracicaba

Latitude $=22,7$ C.A. $D .=100 \mathrm{~mm} \quad \mathrm{~A}=2.353839 \quad \mathrm{I}=106,9928$

\begin{tabular}{crrrrrrrrr}
\hline Mês & \multicolumn{1}{c}{ T } & \multicolumn{1}{c}{ EP } & \multicolumn{1}{c}{ P } & P-EP & ARM & ALT & ER & DEF & EXC \\
\hline 1 & 24 & 122 & 220 & 97 & 100 & 0 & 122 & 0 & 97 \\
2 & 24,7 & 113 & 184 & 70 & 100 & 0 & 113 & 0 & 70 \\
3 & 23,9 & 110 & 137 & 26 & 100 & 0 & 110 & 0 & 26 \\
4 & 21,1 & 75 & 65 & -11 & 90 & -10 & 74 & 0 & 0 \\
5 & 17,6 & 48 & 52 & 3 & 93 & 3 & 48 & 0 & 0 \\
6 & 16,8 & 40 & 46 & 5 & 98 & 5 & 40 & 0 & 0 \\
7 & 17,2 & 45 & 28 & -18 & 83 & -16 & 43 & 1 & 0 \\
8 & 18,9 & 58 & 29 & -30 & 61 & -22 & 50 & 8 & 0 \\
9 & 20,3 & 71 & 60 & -12 & 55 & -7 & 66 & 4 & 0 \\
10 & 22,2 & 95 & 107 & 11 & 66 & 11 & 95 & 0 & 0 \\
11 & 22,9 & 104 & 131 & 26 & 92 & 26 & 104 & 0 & 0 \\
12 & 23,8 & 121 & 198 & 76 & 100 & 7 & 121 & 0 & 69 \\
\hline & 21 & 1007 & 1257 & 249 & & 0 & 992 & 15 & 284 \\
\hline
\end{tabular}

Tabela 3.2. Normais Climatológicas 1917-1996.

Local: Piracicaba, SP

Lat.: $22^{\circ} 42^{\prime} 30^{\circ} \mathrm{S}$ Long.: $47^{\circ} 38^{\prime} 00^{\circ} \mathrm{W}$ Alt.: $546 \mathrm{~m}$.

\begin{tabular}{|c|c|c|c|c|c|c|c|}
\hline Mês & $\mathrm{T}$ do $\operatorname{Ar}\left({ }^{\circ} \mathrm{C}\right)$ & $P(m m)$ & UR do $\operatorname{Ar}(\%)$ & E Classe A & ET Thomth. & & IRS \\
\hline & Média & Tot.Média & Média & \multicolumn{2}{|c|}{$-\mathrm{mm} / \mathrm{dia}=$} & Horas & Ccal $/ \mathrm{cm}^{2} . \mathrm{dia}$ \\
\hline Jan. & 24,4 & 220,8 & 75,7 & 4,4 & 4,1 & 6,4 & 453,36 \\
\hline Fev. & 24,6 & 183,8 & 75,0 & 4,0 & 4,0 & 6,6 & 442,84 \\
\hline Mar. & 24,0 & 142,6 & 75,5 & 3,8 & 3,6 & 6,8 & 397,54 \\
\hline Abr. & 21,8 & 65,7 & 73,9 & 3,7 & 2,7 & 7,5 & 366,79 \\
\hline Mai. & 19,1 & 52,3 & 74,8 & 3,1 & 1,8 & 7,3 & 297,60 \\
\hline Jun. & 17,6 & 43,6 & 74,4 & 2,9 & 1,5 & 7,1 & 281,44 \\
\hline Jul. & 17,3 & 27,7 & 69,3 & 3,6 & 1,4 & 7,9 & 307,09 \\
\hline Ago. & 19,1 & 29,7 & 63,8 & 4,7 & 1,9 & 8,2 & 353,93 \\
\hline Set. & 20,7 & 61,6 & 64,2 & 5,4 & 2,4 & 6,9 & 378,83 \\
\hline Out. & 22,2 & 109,3 & 69,0 & 5,2 & 3,0 & 6,9 & 438,07 \\
\hline Nov. & 23,1 & 128,5 & 69,1 & 5,4 & 3,5 & 7,5 & 480,49 \\
\hline Dez. & 23,8 & 199,3 & 73,8 & 4,8 & 3,9 & 6,6 & 448,63 \\
\hline ANO & 21,5 & 1264,9 & 71,5 & 4,2 & 2,8 & 7,1 & 387,20 \\
\hline
\end{tabular}

FONTE: Departamento de Física e Meteorologia-ESALQ/USP (1997) e Ometto (1991) Adaptação.

$\mathrm{T}=$ Temperatura: $\mathrm{P}=$ Precipitação: $\mathrm{UR}=$ Umidade Relativa: $\mathrm{E}=$ Evaporação: $\mathbb{I R S}=$ =Isolador 
(Dez- Mar) é de $24,2^{\circ} \mathrm{C}$. De acordo com as informações do Soil Txonomy (Soil Survey Staff, 1975) e os dados de temperatura do solo da região de Piracicaba o ambiente térmico é designado como sendo Hypertérmico. Tal designação é devido ser a diferença entre a média do verão e a média da temperatura do inverno superior a $5^{\circ} \mathrm{C}$ vindo o prefixo Hyper. No caso a designação "Térmico" se deve ao fato de temperatura média anual do solo estar entre 16 e $22^{\circ} \mathrm{C}$. Como o total de precipitação média anual durante os 79 anos de registros meteorológicos é de $1.264,9 \mathrm{~mm}$ e com uma média para os meses de inverno de $153 \mathrm{~mm}$ e os meses de verão de $745 \mathrm{~mm}$ (sendo Janeiro o mês mais úmido com 220,8 mm em média), em conseqüência, o regime de umidade dos solos de Piracicaba pode-se considerar como sendo "Udic" (Soil Survey Staff, 1975; Ometto, 1991)- Figura 3.5.

Especificamente no perfil T4 a classificação do regime de umidade é "Aquic" devido a características de encharcamento na maior parte do ano. A cobertura vegetal natural da área pertence ao subtipo Floresta Latifoliada Tropical. Destacam-se: a peroba (Aspidisperma sp.) figueira branca (Ficus doliara, Mart.), pau de alho (Gallezia dorazema) (Ranzani et al., 1966).

\subsection{Trabalhos de campo}

Foram abertas ao todo quatro trincheiras, no transecto calcário e depressão. Nas trincheiras da seqüência T1 a T4, foi possivel examiná-las até a rocha de origem. Em cada trincheira foi feito a descrição morfológica seguindo as orientações contidas nas normas da Sociedade Brasileira de Ciência do solo (Lemos \& Santos, 1984) e completada com os critérios do Soil Survey Manual (Soil Survey Staff, 1951). Após a descrição morfológica foram coletadas amostras compostas deformadas, de cada horizonte e/ou camada, para as análises usuais. Amostras especiais indeformadas e da própria rocha também foram coletadas para a determinação da densidade do solo assim como para estudos micromorfológicos. Tais amostras foram retiradas dos principais horizontes 


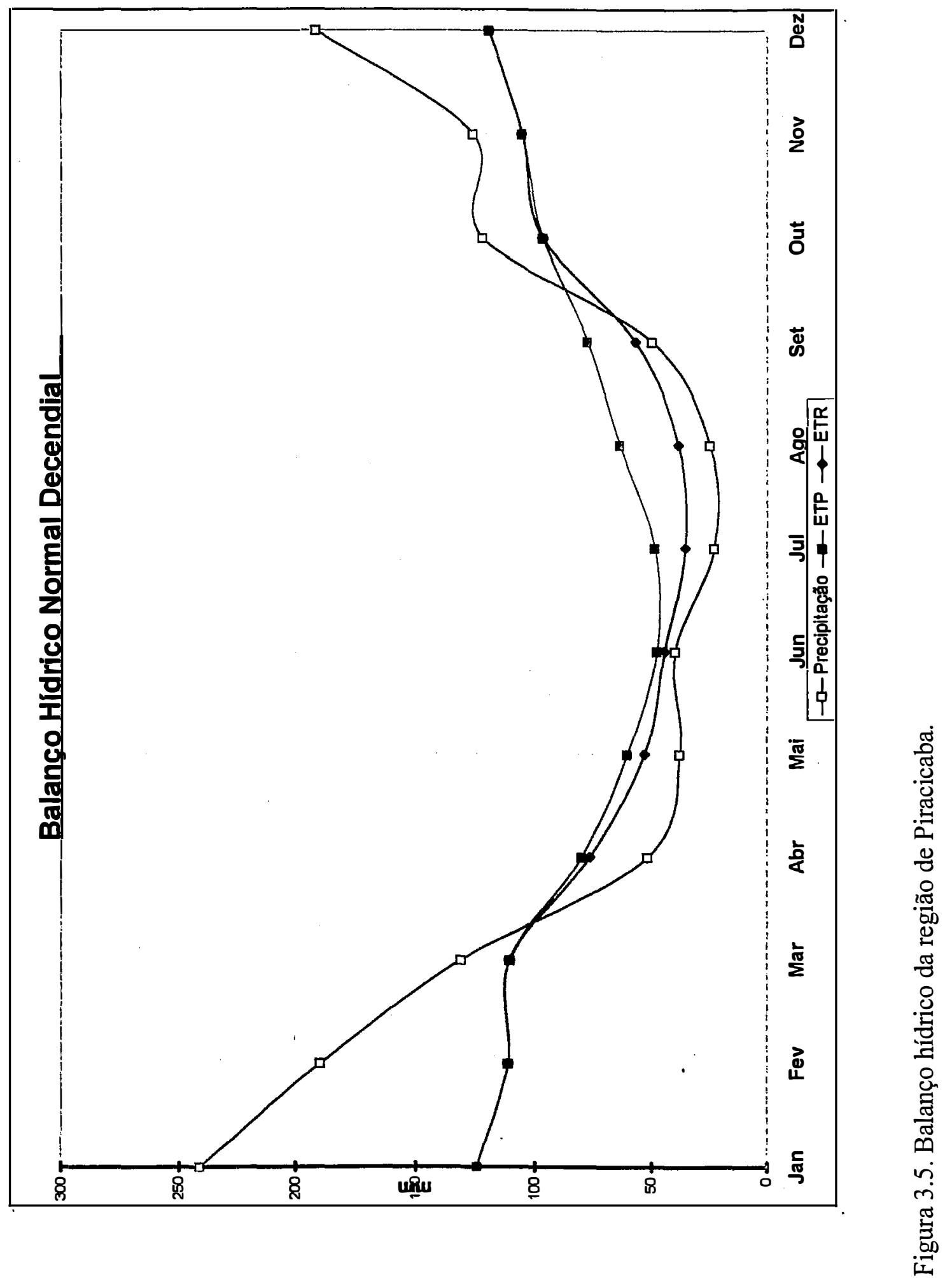


Por ocasião das amostragens, agosto de 1995 (período seco), o perfil T4 se encontrava com encharcamento na altura do horizonte Bt. Houve necessidade de bombeamento do excesso de água para possibilitar as amostragens. Durante o período chuvoso, novembro a abril (ver tabela 3.2.) a depressão onde se localiza o T4 permaneceu alagada. Portanto indo do T1 em direção a trincheira T4 o alagamento temporário tende a aumentar de espessura. Enquanto que no T2 a evidência de encharcamento, se observa apenas na base do perfil, no T4 e dependendo da época do ano, o encharcamento é total, cuja presença é superior a 60 dias. As descrições morfológicas se encontram no apêndice 1 .

\subsection{Análises de Laboratório}

Preparo das amostras- Os trabalhos de laboratório foram conduzidos no Departamento de Ciência do Solo da ESALQ, exceto os que se referem à analise com espectrografia de raios- $x$, que foram realizadas no laboratório de GeoquímicaDepartamento de Petrologia e Metalogênia da UNESP- Rio Claro. As análises de microscopia eletrônica de varredura (MEV) foram feitas no Laboratório de Microscopia da ESALQ, e microsonda feito no IAG - (NUPUGEL) em São Paulo. A Figura 3.6. resume um fluxograma de trabalho de laboratório.

As amostras após secas ao ar, foram destorroadas e peneiradas, obtendose a fração TFSA (terra fina seca ao ar), que constitui a fração $<2 \mathrm{~mm}$ de diâmetro e a fração de calhaus (esqueleto) superior a $2 \mathrm{~mm}$ de diâmetro. Tais amostras foram devidamente armazenadas e identificadas.

\subsubsection{Análises Físicas}

As determinações a seguir foram feitas de acordo com a metodologia indicado pela EMRAPA $(1979,1997)$. 


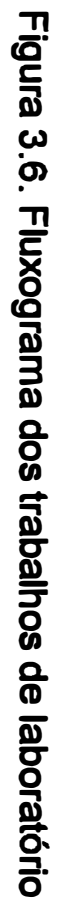
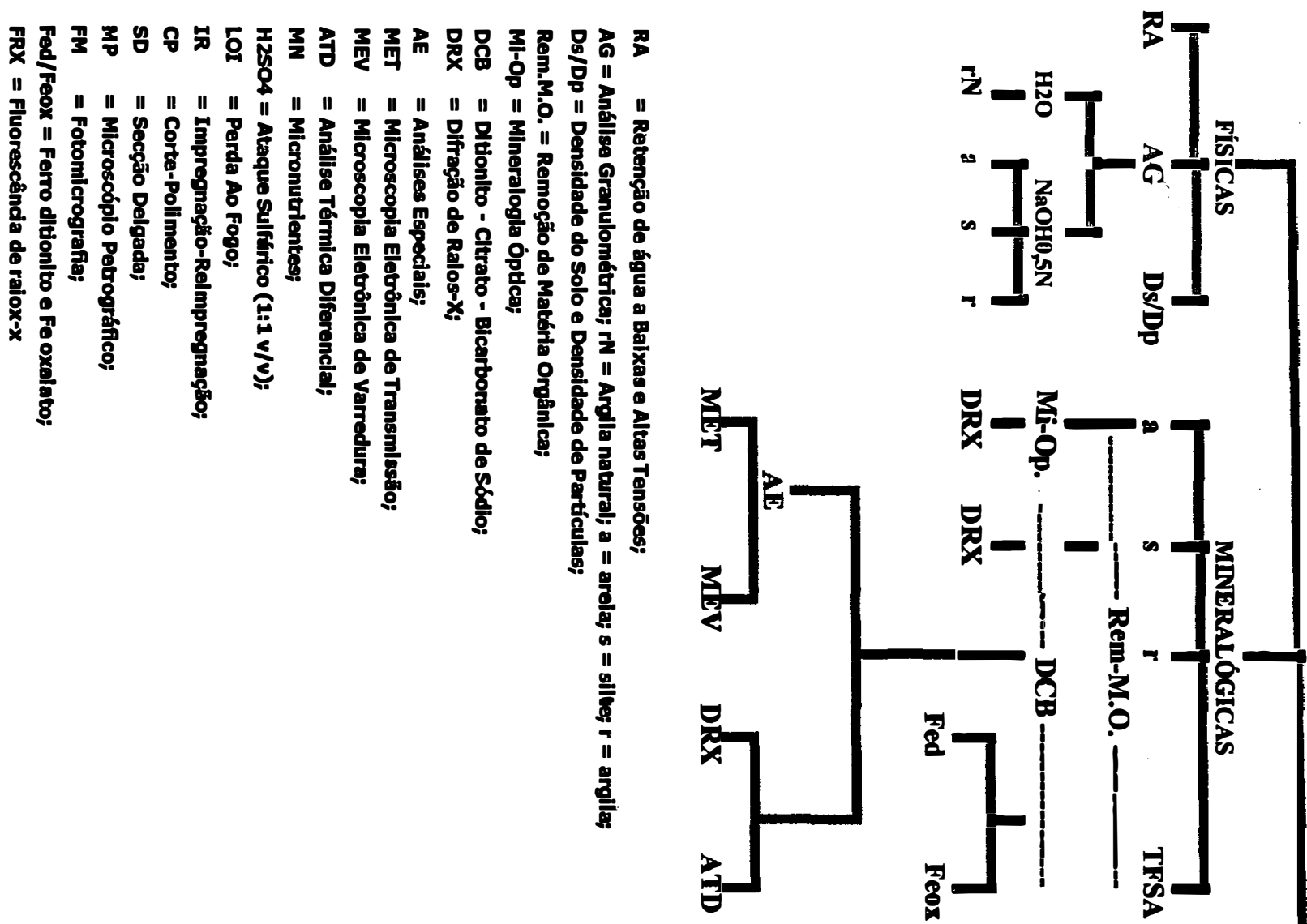

I
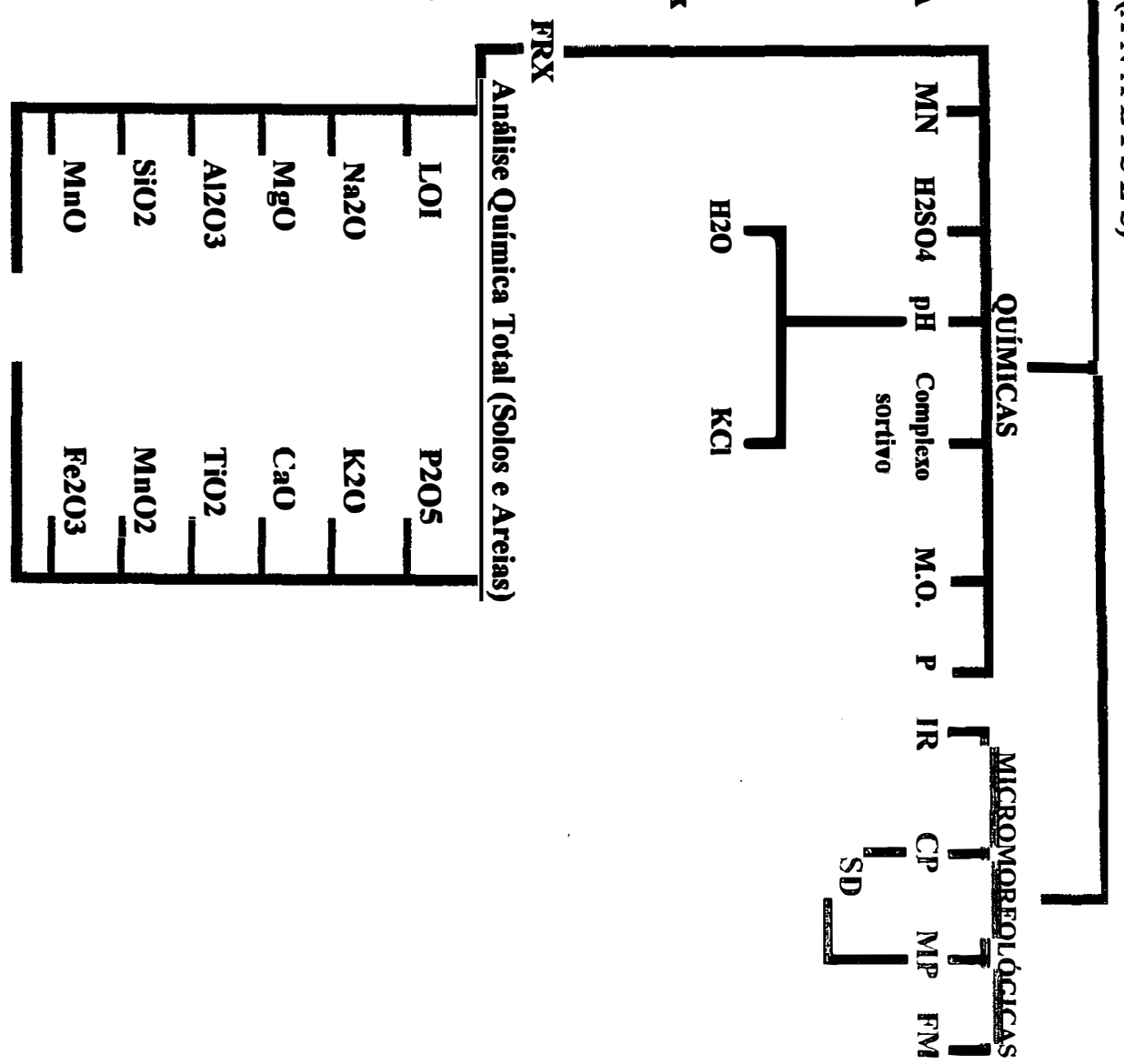
Análises granulométrica- Após a dispersão do solo usando-se uma solução de hidróxido de sódio e agitação horizontal durante 16 horas, a fração areia foi separada das demais frações por tamizagem via úmida (tamiz 270 de $0,05 \mathrm{~mm}$ de malha). As frações silte e argila foram transferidas em provetas de 1 litro, agitadas e após tempo determinado utilizou-se o densímetro para determinação da fração argila. A fração silte foi determinada por diferença de $100 \%$. Nesta mesma amostra e após a leitura a suspensão foi novamente agitada e deixada em repouso. Por sifonação foi separada a fração argila e deixada armazenada em balão de $5 \mathrm{~L}$. O volume foi completado com água destilada, e a suspensão novamente agitada e deixada em repouso (16 h.). Após este tempo foi novamente sifonado a fração argila. Tal processo foi repetido até a completa remoção da argila e completado o volume de $5 \mathrm{~L}$. Alícotas da suspensão foram tiradas para estimativa da quantidade de argila. Através de uma super centrifuga foi separado as frações argila grossa e fina a $30.000 \mathrm{rpm}$ secadas e pesadas (Jackson, 1969).

A fração areia, após secagem e pesagem foi subdividida por tamizagem via seca, em cinco subfrações a saber: areia muito grossa, areia grossa, areia média, areia fina e areia muito fina, com tamizes de números $16,32,60,150$ e 270 correspondente ao intervalo da fração a saber: $2-1 \mathrm{~mm} ; 1-0,5 \mathrm{~mm} ; 0,5-0,25 \mathrm{~mm} ; 0,25-0,10 \mathrm{~mm} ; 0,10$ $0,05 \mathrm{~mm}$.

Argila dispersa em água- é a argila obtida pelo método anterior porém sem usar o dispersante, e sim água desmineralizada.

Grau de floculacão- (GF)- Calculado a partir da argila dispersa em água (ADA) e de argila total (AT). segundo a relação: GF $(\%)=100($ AT-ADA $) / A T$

Densidade do solo (Ds)- Determinado pelo método do torrão impermeabilizado com parafina fundida $\left(60-65^{\circ} \mathrm{C}\right)$.

Densidade das partículas (Dp)- Determinado pelo método do balão volumétrico usando álcool etilico como liquido penetrante.

Porosidade total (PT)-Calculado pela expressão: PT (\%) $=(1-D s / D p) \times 100$ 
Retenção de água a baixas e altas tensões (RA)- Para as determinações de diversos pontos utilizou-se o extrator de placas de pressão ( CAT- 1200). Nas amostras após saturadas com água durante 72 horas foi determinada a umidade de equilíbrio com os potenciais matriciais de $-0,01,-0,05,-0,1,-0,5,-1,-5,-15$ atmosferas e utilizou-se o sofware de Van Genuchten (1980).

\subsubsection{Análises Químicas}

As análises químicas de rotina de solo foram realizadas no Departamento de Solos segundo a metodologia de análises presente nas indicações de Raij et al. (1983). $\mathrm{O} \mathrm{pH}$ foi determinado em água e $\mathrm{KCl} 1 \mathrm{~N} 1 \mathrm{~mol} / \mathrm{L}$, na relação 1:2,5. O carbono orgânico pelo método titulométrico com sulfato ferroso amoniacal (Allison, 1965). As bases trocáveis foram extraídas com $\mathrm{KCl} \mathrm{N}$; a acidez potencial determinado pelo método do acetato de cálcio $1 \mathrm{~N}$ a pH 7,0 e titulação alcalinométrica do extrato com $\mathrm{NaOH}$ a 0,25 N. A Capacidade de Troca de Cátions (CTC)- obtida por meio da soma de bases (SB) e da acidez potencial (H+Al) -(Raij et al. 1983).

O fósforo disponível foi determinado pelo método da resina trocadora de ânions. Os micronutrientes determinados usando-se o extrator DTPA- TEA-0,1M (dietileno-triamino-pentacético e trietanolamina) e a leitura no espectrofotómetro de absorção atômica para o $\mathrm{Zn}, \mathrm{Cu}, \mathrm{Fe}$ e $\mathrm{Mn}$. No caso do boro foi determinado pelo método modificado por Abreu (1996), usando $\mathrm{BaCl} .2 \mathrm{H}_{2} \mathrm{O}_{2} \mathrm{O}, 125 \% \mathrm{em}$ microondas (10 g de TFSA/20 ml de $\mathrm{BaCl}_{2}$ 0,125\%). O sulfato extraído por solução ácida de acetato de amônio $\mathrm{NH}_{4} \mathrm{OAc}$ 0,25 $\mathrm{N}$ e com leitura no espectrofotometro (Camargo et al.,1986).

Ataque sulfúrico- Consistiu no tratamento da $1 \mathrm{~g}$ de TFSA com $20 \mathrm{ml}$ de $\mathrm{H}_{2} \mathrm{SO}_{4} 1+1$ pela ação da fervura sobre refluxo com posterior resfriamento, diluições e filtrações, segundo indicações de EMBRAPA $(1979,1997)$. No extrato deste ataque foi determinado os óxidos de $\mathrm{Al}, \mathrm{Ti}, \mathrm{Fe}$ e $\mathrm{Mn}$. $\mathrm{O}$ índice $\mathrm{Ki}$ foi calculado pela relação molecular entre o \% de $\mathrm{SiO}_{2}$ e $\mathrm{Al}_{2} \mathrm{O}_{3}$.

Ferro amorfo- Extraído com oxalato ácido de amônio, segundo Mckeague (1978). 
Ferro livre_- Extraido com ditionito-citrato-bicarbonato (DCB), segundo Mehra \& Jackson (1969).

\subsubsection{Preparo das amostras para Análise Mineralógica}

O preparo das amostras de solos para a identificação dos minerais presentes nas diversas frações, foi feito com base nas indicações contidas em Jackson (1969). Inicialmente a TFSA foi tratada com $\mathrm{H}_{2} \mathrm{O}_{2}$ a $30 \%$ a quente para oxidação do material orgânico. Após diversos tratamentos com $\mathrm{H}_{2} \mathrm{O}_{2}$, até redução da reação de oxidação, a amostra foi lavada com acetato de sódio $1 \mathrm{~N}$ a pH 5,0, para remoção dos cátions liberados.

A seguir as amostras foram tratadas para remoção dos óxidos de ferro com uma solução de citrato e bicarbonato de sódio, a quente, sendo adicionado o ditionito de sódio para reduzir o ferro. Tal tratamento foi repetido até a amostra de solo apresentar cor acinzentada, indicando assim completa remoção dos óxidos de ferro. Após tal remoção as amostras foram saturadas com $\mathrm{NaCl} \mathrm{N}$, para facilitar a dispersão. A fração areia foi separada das demais frações por tamizamento via úmida. Após secagem tal fração foi dividida em cinco subfrações por tamizamento a seco, pesadas e acondicionadas adequadamente. A fração silte e argila foram separadas por centrifugação e acondicionadas em frascos. A fração silte foi secada.

Subfrações em suspensão da fração argila foram tomadas e colocadas em tubos de centrifuga. Uma subfração de argila foi saturada com $\mathrm{KCl} \mathrm{N}$ e a outra com $\mathrm{MgCl}_{2} \mathrm{~N}$.

A saturação com $\mathrm{K}$ foi feito através de cinco lavagens com $\mathrm{KCl} \mathrm{N}$. Na argila em suspensão e no frasco de centrífuga foi adicionado o $\mathrm{KCl}$ ao mesmo tempo que sofria agitação mecânica. Posteriormente a suspensão sofreu centrifugação a 1.500 rpm. O sobrenadante foi removido e novo processo de saturação foi efetuado, até atingir as 5 lavagens.

Após as lavagens foi feito a eliminação dos cloretos, da seguinte maneira: 2 lavagens com $100 \%$ de etanol; 2 lavagens com $50 \%$ de etanol e $50 \%$ de água; e 1 
lavagem com $100 \%$ de água destilada. Posteriormente foi feito o teste da presença ou não de cloretos usando o $\mathrm{AgNO}_{3}$. Se eventualmente houvesse cloretos novo lavagem com água seria necessário.

A saturação da outra subfração de argila com $\mathrm{MgCl}_{2} \mathrm{~N}$ foi feita nos mesmos moldes que a saturação com $\mathrm{KCl}$. As amostras de areia (fração modal) e do silte foram montadas em porta amostras especiais e prontas para serem irradiadas no raios- $\mathrm{X}$.

Preparo das amostras orientadas de argila- $\mathrm{Na}$ suspensão de argila saturada com $\mathrm{K}$ e armazenada num frasco foi retirado por pipetagem, uma alíquota de 10 $\mathrm{ml}$ sob contínua agitação. Posteriormente tal alíquota foi transferida a superficies de uma lâmina de vidro e deixado secar em superfície plana. $\mathbf{O}$ mesmo procedimento foi feito com argila saturada com Mg. Após a transferência da suspensão para á lâmina de vidro, foram adicionadas gotas de etileno glicol e deixado secar em superficie plana.

Preparo de amostras para identificação dos óxidos de ferro

Amostras de $1,0 \mathrm{~g}$ de argila foi tratada com $\mathrm{NaOH} \mathrm{Mol} \mathrm{L}^{-1}$ a quente por $1 / 2$ hora (Kämpf Schwertmann, 1982) e posteriormente transferida para lâmina de vidro e irradiada no aparelho de raios-X.

\subsubsection{Difração de Raios - X}

O aparelho utilizado foi um Rigaku com tubo de Cobre (Kœ de 0,15418 $\mathrm{nm})$ e filtro de níquel. As condições do aparelho foram de $40 \mathrm{kw}$ e $20 \mathrm{~mA}^{\circ}$, com sistema de fendas $\mathrm{DS}, 1^{\circ} \mathrm{RD}, 1^{\circ} \mathrm{RD} 0,15 \mathrm{~mm}, \mathrm{SS} 1^{\circ}$. As amostras foram irradiadas entre $3-60^{\circ}$ $2 \theta$ para as frações silte e areia e, de $3-30^{\circ} 2 \theta$ para a fração argila. A velocidade de varredura foi de $2^{\circ} 2 \theta$ durante minuto. As amostras de argila saturadas com $\mathrm{K}$, sofreram diversos tratamentos, a saber: amostra natural; aquecida a $350^{\circ} \mathrm{C}$ e $550^{\circ} \mathrm{C}$. As amostras de argila saturadas com $\mathrm{Mg}$ sofreram tratamentos com etileno glicol. Todas elas foram irradiadas de acordo com as especificações já descritas anteriormente.

A identificação dos minerais foi feita utilizando-se diversas chaves existentes na literatura entre elas Brown (1961); Jackson (1969). A tabela 3,3 indica os principais espaçamentos utilizados na identificação dos minerais da fração argila. 
Tabela 3.3. Principais espaçamentos interplanares utilizados no reconhecimento de minerais da fração argila.

\begin{tabular}{lcl}
\hline Mineral & Espaçamento d (nm) & \multicolumn{1}{c}{ Características } \\
\hline Caulinita & 0,72 e 0,35 & eliminado com aquecimento a $550^{\circ} \mathrm{C}$ \\
Gibbsita & 0,485 & eliminado com aquecimento a $350^{\circ} \mathrm{C}$ \\
Vermiculita & 1,4 & colapsa para 1,0 nm com aquecimento a $550^{\circ} \mathrm{C}$ \\
Montmorilonita & 1,4 & expande para $1,6-1,8$ com etileno glicol \\
Micas & 1,0 & permanece com aquecimento a $550^{\circ} \mathrm{C}$ \\
Quartzo & 0,33 & não altera com os tratamentos \\
Feldspatos & 0,32 & não altera com os tratamentos \\
\hline
\end{tabular}

\subsubsection{Fluorescência de Raios- $X$}

A estimativa dos óxidos totais a partir da análise de Fluorescência de raios- $\mathrm{X}$ foi efetuada segundo Jones (1986). No caso especifico deste trabalho, esta técnica foi utilizada na determinação do $\mathrm{Ti}, \mathrm{Mn}, \mathrm{Fe}^{3+}, \mathrm{Al}^{3+}, \mathrm{Si}, \mathrm{P}, \mathrm{Ca}, \mathrm{Mg}, \mathrm{Na}$ e $\mathrm{K}$ tanto na fração areia como no solo total.

Preparo da amostra - Amostras de solo ou da fração areia (5 g) foram trituradas em almofariz de tungstênio. Sobre o molde de uma prensa especifica foram depositados 4,0 g de ácido bórico (30\%) e, sobre este, foi espalhado 1,0000 g (areia ou solo total). O material foi então prensado a $240 \mathrm{MPa}$ obtendo pastilhas de $2,5 \mathrm{~cm}$ de diâmetro (Jackson, 1969). Tais pastilhas foram levadas para o porta amostra do aparelho de espectrografia (modelo Philips, 2510, da UNESP em Rio Claro). Curvas padrões de regressão linear foram determinadas para cada um dos elementos analisados. Os resultados são apresentados em forma de óxidos. 


\subsubsection{Análise Térmica Diferencial}

O método utilizado foi elaborado por Dixon (1966). A amostra argila $\mathrm{Mg}$ saturada, após secagem, foi colocada em porta amostras especiais tendo como material inerte o óxido de $\mathrm{Al}$ previamente calcinado a $900^{\circ} \mathrm{C}$. Curvas padrões foram obtidas tanto para caulinita como para gibbsita, usando-se o método do pesagem das áreas dos picos para estimar os teores destes minerais. Os gráficos foram obtidos num aparelho Rigaku até $650^{\circ} \mathrm{C}$, numa faixa de $8^{\circ} \mathrm{C}$ a cada minuto. $\mathrm{O}$ pico da caulinita foi identificado a $550^{\circ} \mathrm{C}$, o da montmorilonita e/ou vermiculita a $250^{\circ} \mathrm{C}$.

As análises semi-quantitativas dos minerais da fração argila foram estimadas pela determinação das áreas dos picos como indicado por John et al. (1954). Para a caulinita foi utilizado a medição da área do pico a $550^{\circ} \mathrm{C}$ como descreveu Dixon (1966) na análise térmica diferencial.

\subsubsection{Preparo das amostras para microscopia ótica.}

A fração areia, isenta de óxidos de ferro e matéria orgânica, foi utilizada na montagem de lâminas para estudo de minerais leves e pesados. Duas gramas da fração areia foi adicionada a tubos de centrífuga contendo bromofồrmio (densidade 2,9). Após centrifugação a 2.500 rpm (Jackson, 1969), os minerais pesados ficaram no fundo do tubo e os leves na parte superior. A parte inferior do tubo foi colocado em um compartimento contendo gelo seco. Após o congelamento da parte inferior do tubo, o sobrenadante contendo os minerais leves foi filtrado, ficando os minerais leves aderido ao filtro, o qual foi pesado e acondicionado.

Após o descongelamento da parte inferior do tubo de centrífuga, o líquido foi filtrado, ficando os minerais pesados aderidos ao papel filtro. Após secagem o material foi pesado e acondicionado. As lâminas dos minerais leves e pesados foram 
montadas com bálsamo de Canadá, de índice de refração conhecido e examinadas em microscópio polarizante.

\subsubsection{Preparo de amostras para micromorfologia}

Foi utilizado blocos indeformados de solos devidamente orientados e secos, colocados em recipientes de alumínio; dentro de desecadores adaptados para receber as resinas. A impregnação foi baseada na metodologia originalmente descrito por Brewer (1964) com ligeiras modificações de Mendes et al., (1973).

A resina utilizada foi a ortoftálica T-208, diluída com monômero de estireno na proporção 1:1 e como catalizador o Luperox DDM. Após impregnar sob vácuo, as amostras foram secas ao ar durante 4 dias, e posteriormente levadas a estufa a $60^{\circ} \mathrm{C}$, para acelerar o endurecimento. Após o corte, tanto de amostras horizontais como verticais, procedeu-se o polimento de uma das fases e montagem em lâminas de vidro com Araldite. Feito isso, procedeu-se ao corte na outra fase seguindo-se diversos polimentos usando carburundum de granulometria decrescente, até aproximadamente 30 $\mu \mathrm{m}$ de espessura.

\subsubsection{Microscopia Eletrônica de Transmissão (MET)}

A preparação do material consistiu em dispersar $1 \mathrm{~g}$ de solo em $50 \mathrm{ml}$ de água destilada num tubo de centrífuga, agitando mecanicamente durante 15 minutos, passando por peneira $(53 \mu \mathrm{m})$. O sobrenadante foi centrifugado a $300 \mathrm{rpm}$ por 5 minutos, ficando a amostra pronta para preparar as telinhas que foram irradiadas através do MET- Zeiss- EM 900 da ESALQ (Jackson, 1969; Kitajima, 1997).

\subsubsection{Microscopia Eletrônica de Varredura (MEV)}


Amostras de solo e/ou camadas de silex foram cortadas em pequenos pedaços e recobertas com ouro, com o uso do Evaporador Balzers-Sputtering e estudadas no MEV- Zeiss- DSM 940, na ESALQ; seguindo os protocolos es instruções para o seu uso (Kitajima, 1997).

\subsubsection{Microsonda}

A microanálise de raios-X ou Microsonda é um procedimento de análise quantitativa para determinar que elementos estão presentes em um ponto da microestrutura do mineral particularmente, obtendo-se os resultados através do espectro que permite sugerir a composição do mineral examinado, sendo confirmado através da sua morfologia (Bozzola \& Russell, 1992).

Amostras de solo e/ou fragmentos das camadas examinadas de aproximadamente $1 \mathrm{~cm}$ de diâmetro foram preparadas sob vácuo $\left(\mathrm{P}=2 \times 10^{-2} \mathrm{mb}\right)$, durante cinco minutos no “ Sputter coater S150B da Edwards". As amostras foram analizadas no microscópio eletrônico de varredura (GEOL-JSM-T330) acoplado ao "EDS Noram do "Baker Hughes Micro-Z"'.

\subsubsection{Cálculos granulométricos}

Com a utilização dos dados da distribuição de freqüencia das areias (via seca) de todos os horizontes e camadas estudadas, foram determinados os seguintes parâmetros sedimentológicos: média gráfica, desvio padrão, assimetria e curtose gráfica. Para a realização desses cálculos utilizou-se o sofware "PHI" "Programa de Microcomputador para Análise Estatística da Granulometria de Sedimentos”, desenvolvido por Lier \& Torrado (1992) e baseado nos estudos de métodos gráficos de Folk \& Ward (1957). De acordo com esses autores, os cálculos dos parâmetros sedimentológicos são extraidos de curvas cumulativas das distribuições percentuais das frações das partículas, com escala normal na ordenada e, na abscissa, a escala $\Phi($ phi), 
que é função logaritmica do diâmetro de partícula. Para tanto, os valores dos diâmetros médios (D) das frações das partículas, em milimetros, são transformados para a escala proposta, de forma que $\Phi$ seja o logaritmo na base 2 do inverso do diâmetro: $\Phi=-\log _{2} \mathrm{D}$. 


\section{RESULTADOS E DISCUSSÃO}

\subsection{Morfologia dos solos na catena}

O exame morfológico de todos os perfis estudados (Tabela 4.1) indicam, em profundidade, as variações devidas ao próprio material originário assim como à ação dos processos de formação influenciado principalmente pela oscilação do lençol freático. Neste aspecto a Figura 4.1 resume as principais tendências das evoluções dos horizontes diagnósticos, base de apoio da hipótese traçada.

Note que nesta seqüência diversas camadas são comuns para os perfis 1 a 4, entre elas as camadas de concentração de material rico em manganês e da lage de silex. No caso de lage de silex ela se inicia a $286 \mathrm{~cm}$ no $\mathrm{T} 1,215 \mathrm{~cm}$ no T3 e 214 no T4, enquanto a camada mais visivel morfologicamente de concentração de manganês se encontra no $\mathrm{T} 1$ nos horizontes $\mathrm{C} 3$, $\mathrm{C} 5$ e $\mathrm{C} 7$; no $\mathrm{T} 2$ nos horizontes $\mathrm{Clg}$ e $\mathrm{C} 4$ e no $\mathrm{T} 4$ no Clg.

Por outro lado as camadas de argilito foram identificadas principalmente no perfil 1, 2 e 4 nas camadas $\mathrm{C}$, no caso $\mathrm{C} 2, \mathrm{C} 3$ e C4 no T1 e C3 no T2 e C2 no T4. As "bonecas de silex" de tamanho e formas as mais variadas, ocorrem praticamente em todo os perfis, porém, decrescendo do $\mathrm{T} 1$ em direção ao $\mathrm{T} 4$ onde a presença é rara.

Nódulos ferromanganiferos, muito pequenos a pequenos, com forte reação com água oxigenada estão disseminados em todo o perfil não havendo camada especifica de concentração. A presença das bonecas de silex e nódulos ferromanganiferos e do argilito, este nos horizontes inferiores, permite um machetado de 


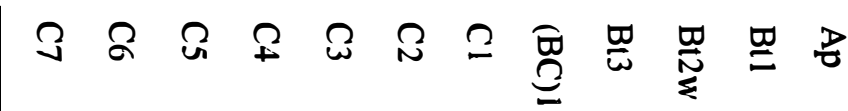

$$
\begin{aligned}
& \text { mmm!n: }
\end{aligned}
$$

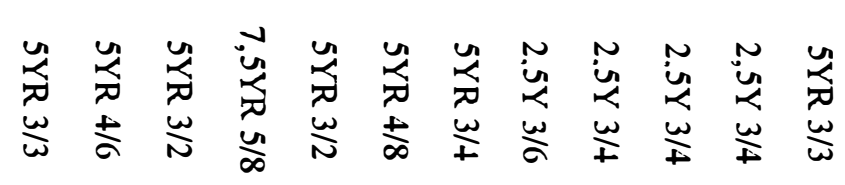

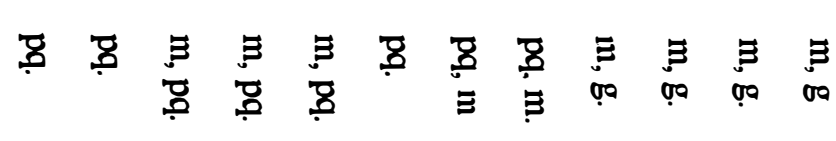

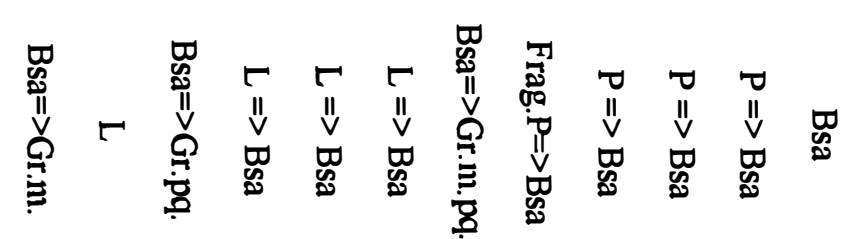

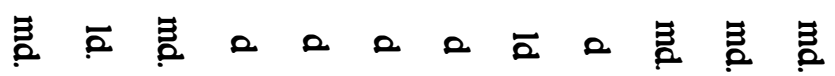

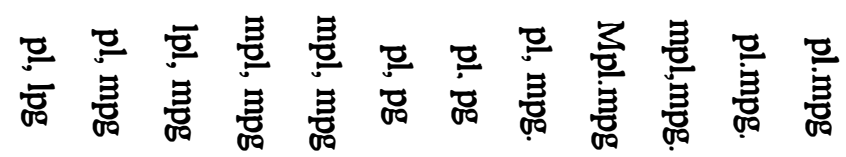

$$
\begin{aligned}
& \text { | }
\end{aligned}
$$

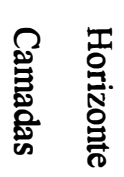

$$
\begin{aligned}
& \text { 合 }
\end{aligned}
$$

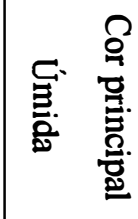

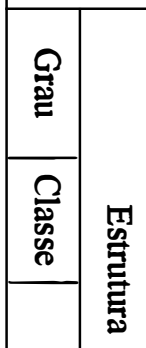

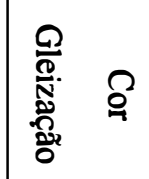

$$
\begin{aligned}
& \text { 붕 }
\end{aligned}
$$

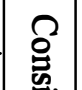

$$
\begin{aligned}
& \text { 产 } \\
& \text { 종 }
\end{aligned}
$$

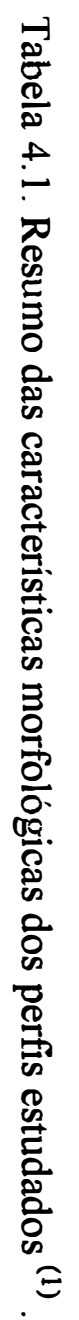




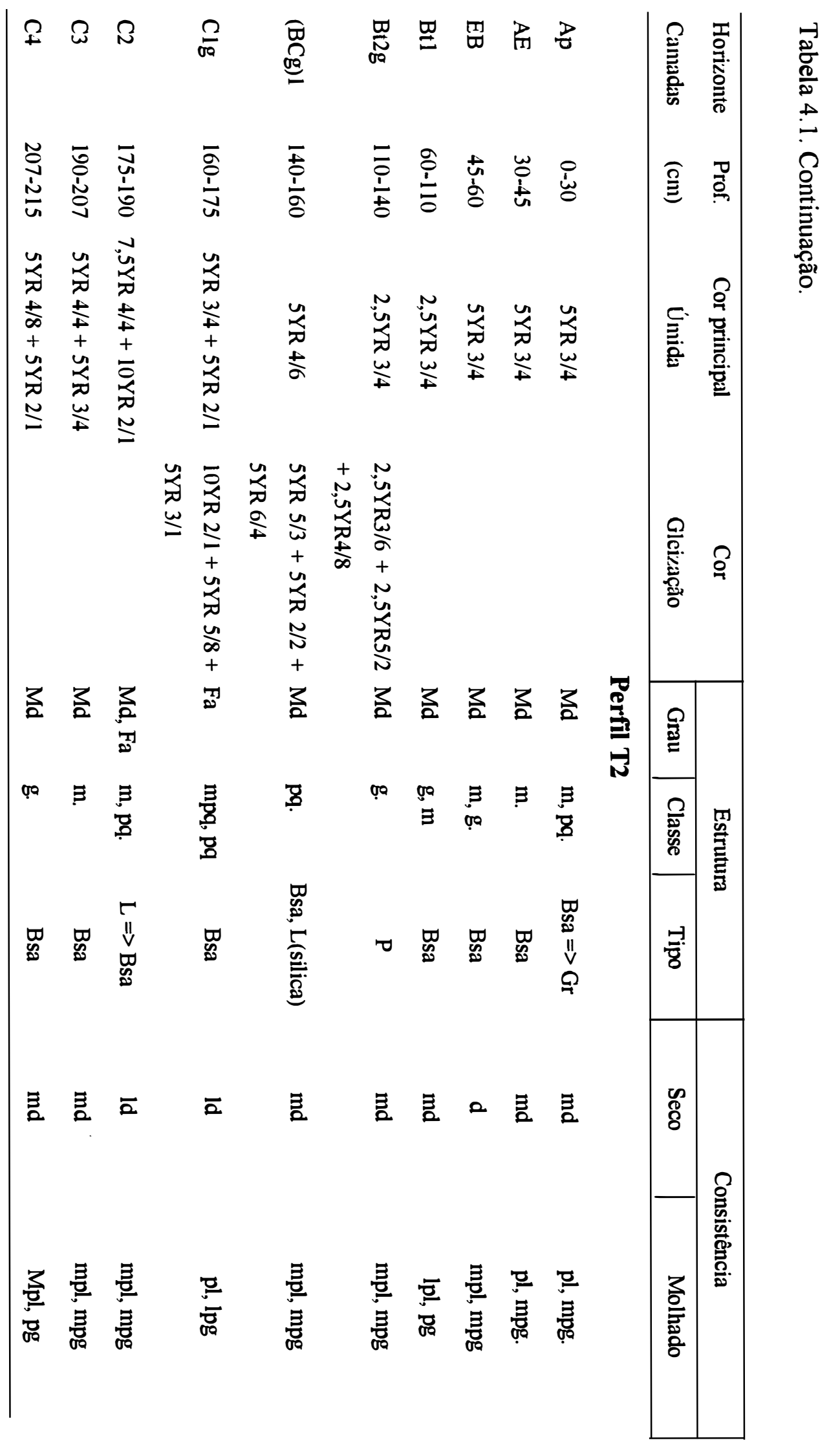




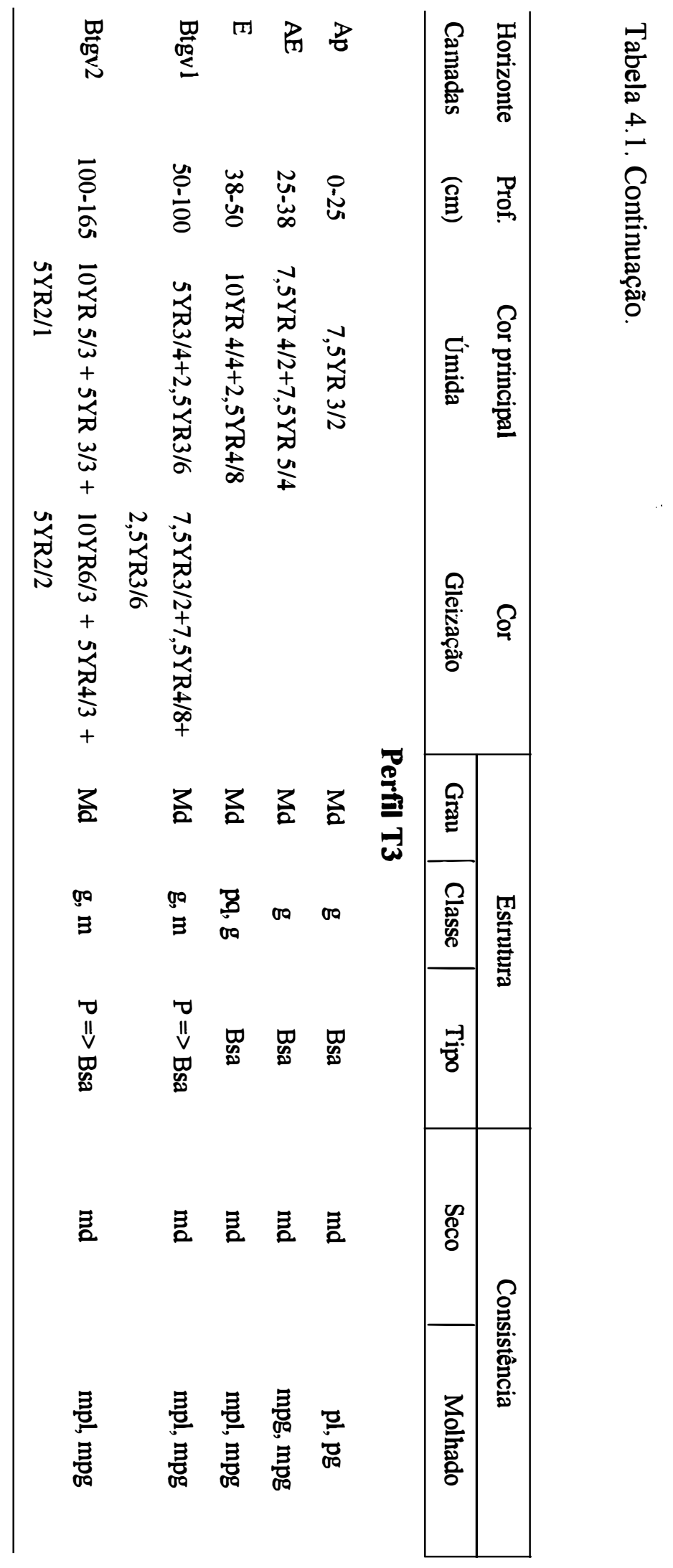




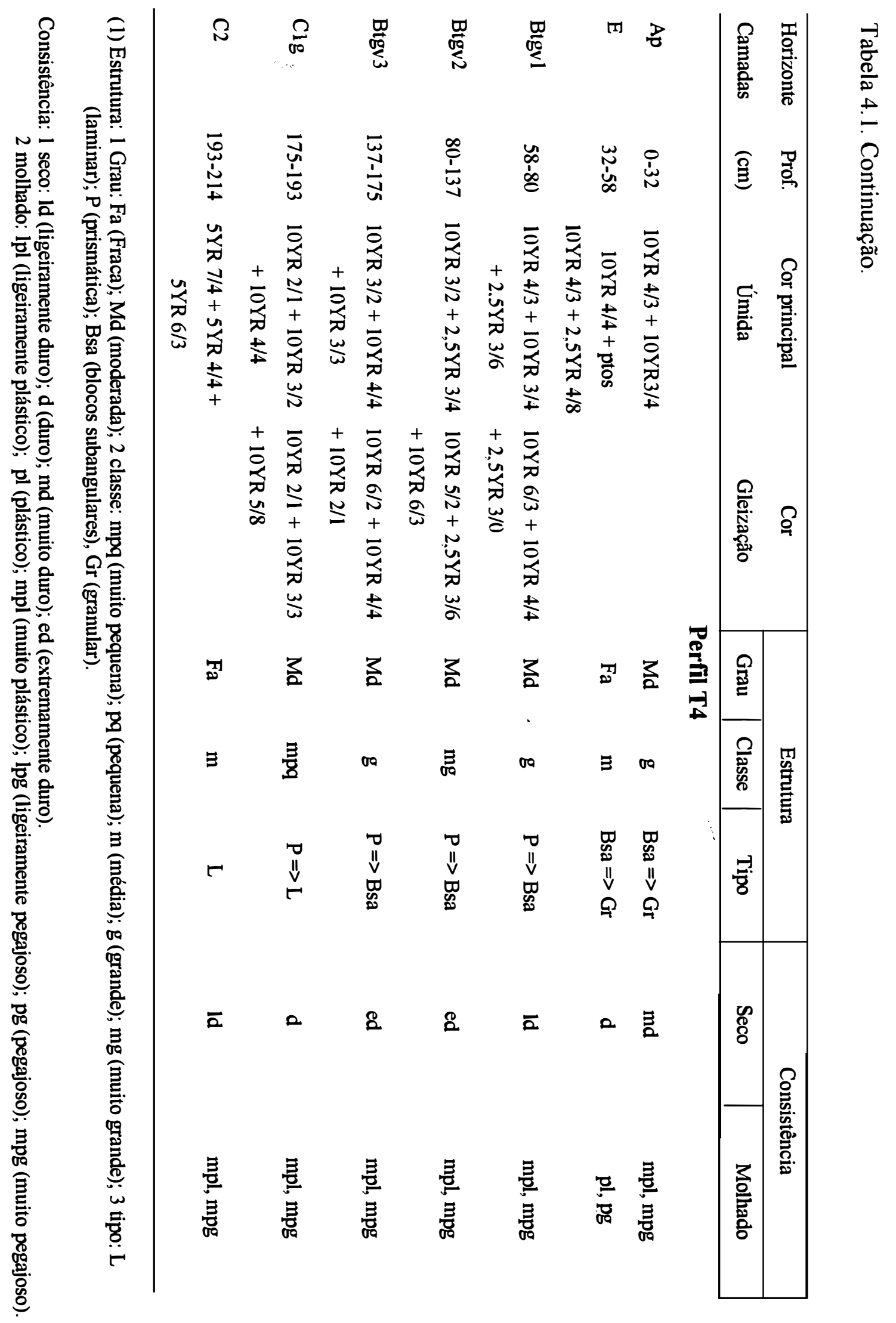




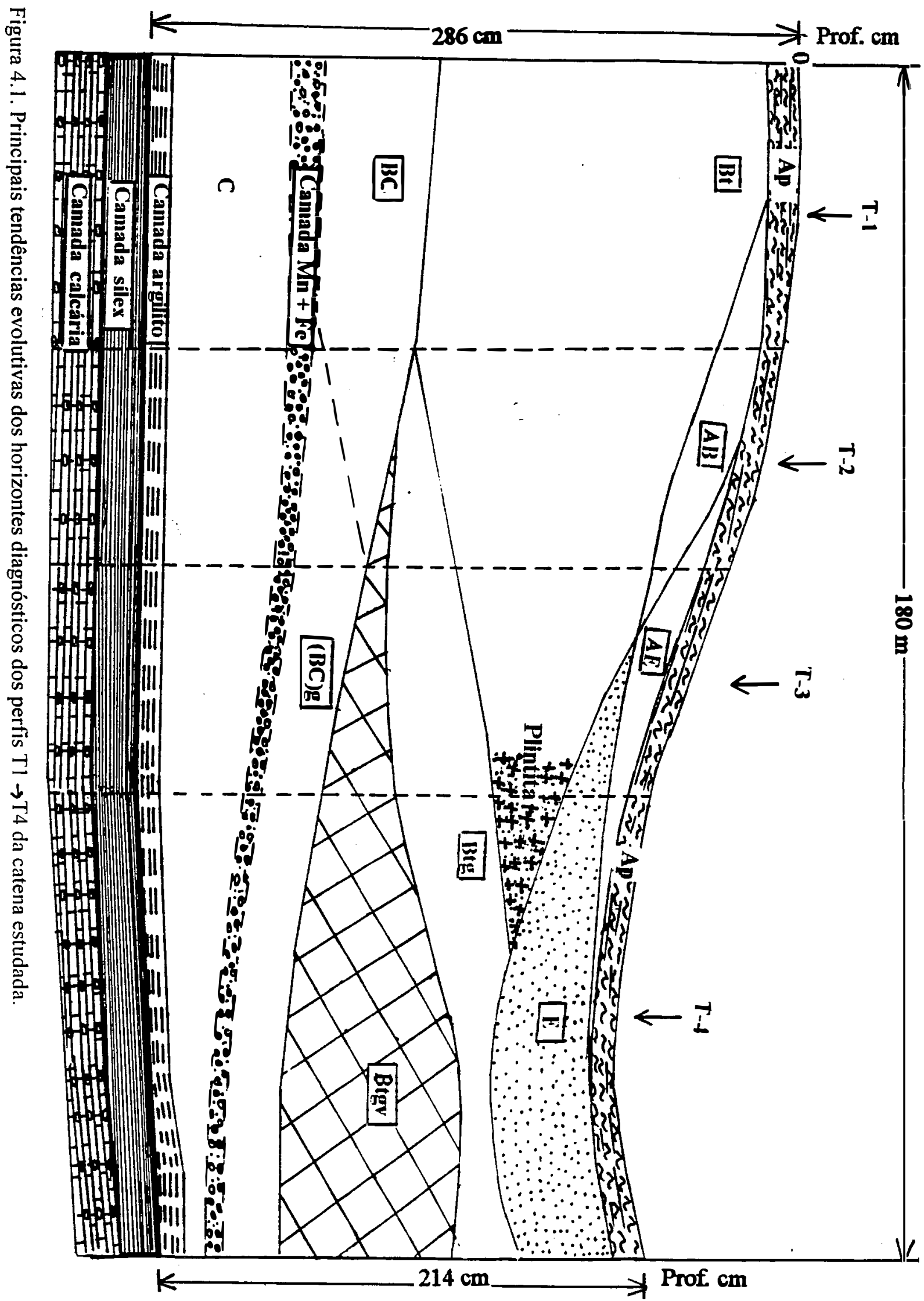


cores em toda a massa do solo. Tal machetado confunde-se com as cores de gleização principalmente nos horizontes mais inferiores dos perfis 2 e 3 e em todo o perfil T4.

As cores principais dos horizontes $\mathrm{Bt}$ do $\mathrm{T} 1$, no caso matizes 2,5YR 3/4 a $3 / 6$ vão sendo gradativamente passando para matizes $5 \mathrm{YR}$ no $\mathrm{Bt}$ do $\mathrm{T} 3$ passando a $10 \mathrm{YR}$ no $\mathrm{Bt}$ do T4. Tais transformações são devidas unicamente à ação do alagamento temporário, que permite a presença de hematita no caso de $\mathrm{T} 1$ e da goethita nos solos com matizes 5YR e 10YR (Resende, 1976; Karmanova, 1981; Schwertmann et al., 1982; Duchaufour, 1982; Kämpf \& Schwertmann, 1983).

Em termos de estrutura dos horizontes $\mathrm{Bt}$, há uma tendência de evolução indo do $\mathrm{T} 1$ ao $\mathrm{T} 4$. No $\mathrm{T} 1$ a estrutura é prismática de tamanho médio e grau moderado a forte passando a tamanho grande no T3 e T4 e grau muito forte. Particularmente neste último perfil há sensivel fendilhamento com inclinação de 40 a $45^{\circ}$ formando estruturas em forma de cunha, como a descreve Buol et al. (1983) isto no Bt3, com grau forte. No Btl a estrutura é prismática, grande e de grau forte tendendo para uma colunar.

Em relação a drenagem interna destes perfis, o $\mathrm{T} 1$ é caracterizado por apresentar boa drenagem até a altura do (BC)1 onde a cor principal tem matiz 2,5YR. A partir desta profundidade ocorre a presença de pontuações de gleização indicando uma redução em drenagem motivado principalmente pelas camadas de argilito e da lage de sílex. No T2 a drenagem até os $100 \mathrm{~cm}$ é considerada boa para se transformar em moderada a partir desta camada. No T3 a ação do lençol freático já se manifesta a partir do horizonte AE com drenagem moderada e impedida. No T4 a drenagem já é totalmente impedida.

Em relação a seqüência de horizonte e de camadas especiais a figura 4.1 ilustra as possiveis formações observadas durante os exames morfológicos. Vindo do T1 em direção ao T4, o horizonte Bt do T1 de cor na faixa de 2,5YR 3/4 deixa espaço para a formação dos horizontes de transição $\mathrm{AE}$ e $\mathrm{EB}$ no $\mathrm{T} 2$. Neste perfil já ocorre a manifestação da oscilação do lençol freático com a presença de gleização a partir do Bt2. A medida que se dirige para o T3 e devido a maior ação do alagamento, praticamente a partir do horizonte $\mathrm{AE}$, há completa descoloração do horizonte $\mathrm{E}$ com cores passando para os matizes 10YR 4/4. Os horizontes Bt apresentam características gleizadas e 
vérticas. No caso do T4, com encharcamento acentuado e com maior tempo de residência da água no local, há aumento na descoloração do horizonte $\mathrm{E}$ e maior manifestação das características vérticas no Bt. Neste caso e em particular no Btgv o fendilhamento das estruturas já é em forma inclinada com cores tendendo para a neutralidade, intimamente gleizada.

Na parte inferior do horizonte E do T4 e na superior do horizonte Btgvl, há ocorrência de pontuações de material com matizes mais avermelhada, faixa de 2,5YR e 5YR com aspecto de material plíntico. Outra evidência que será útil no esclarecimento da gênese deste perfil se refere a pequenas concentrações mais argilosas, de forma irregular no horizonte E. Tais concentrações apresentam as mesmas características dos horizontes Btl.

Quanto a cerosidade ela foi identificada em toda a catena estudada principalmente no $\mathrm{Bt}$. Em relação ao $\mathrm{T} 4$ a presença das superficies de pressão (slickensides), se confunde com a cerosidade. Apesar da cerosidade ter sido identificada, inclusive com lupa de 20x de aumento, e em torrão seco, existe a possibilidade de tal característica não ser argila translocada.

Como se observa (Figura 4.1) os atributos morfológicos dos horizontes dos perfis T1 ao T4 são influenciados pelas oscilações e posição do lençol freático. Os dados observados de campo sugerem que a formação dos horizontes $E$ nos perfis 3 e $4 \mathrm{e}$ dos horizontes de transição $\mathrm{AE}$ e EB do $\mathrm{T} 2$ se devem à ação do encharcamento.

De maneira geral a distribuição de base dos horizontes e/ou camadas do perfil T1 é aleatória e a distribuição relativa porfiroesquélica. A estrutura plásmica é isótica para os horizontes superficiais ou ligeiramente undúlica (Figuras 4.2 A e 4.2 B). O plasma, em torno de $45 \%$ com cores vermelho escuro acinzentado (7,5YR $3 / 2)$ a vermelho escuro (7,5YR 3/6) é caracterizado pelos oxi-hidróxidos de ferro, caulinita e micas.

Quanto as feições pedológicas há dominância de glébulas seguido por nódulos e concreções (Figuras 4.2 C, 4.2 D, 4.2 E, 4.2 F, 4.2 G, 4.2 H, 4.2 I e $4.2 \mathrm{~J}$ ). Os nódulos se apresentam ovóides até arredondados, fracamente aderentes e fortemente 
individualizados, e na maioria das vezes separado pela dessecação com abundância de porosidade fissural, de cor preta (5YR 2/1).

Os poros são dominantes em relação às fissuras, câmaras e cavidades subangulares. Estas formam uma rede poliédrica com preenchimento total ou parcial de ferrans (Figuras $4.2 \mathrm{~K}, 4.2 \mathrm{~L}, 4.2 \mathrm{M}, 4.2 \mathrm{~N}, 4.2 \mathrm{O}$ ).

Em relação ao esqueleto, em torno de $97 \%$ é constituído de quartzo ocorrendo ainda rutilo, zircônio, turmalina e óxidos de ferro.

As concentrações plásmicas dos horizontes $\mathrm{B}$ do $\mathrm{Tl}$ são representadas pelas glébulas e cutans de segregação e/ou iluviação (argilans). Estes estão associados a canais, com preenchimento parcial (Figuras $4.2 \mathrm{P}$ e $4.2 \mathrm{Q}$ ). A Figura $4.2 \mathrm{R}$ indica a fotomicrografia do horizonte álbico do T4. Observe a descoloração do horizonte com perda de material plásmico (cor mais amarelada) e ainda algumas concentrações mais argilosas (cor mais avermelhada) como testemunhos do Bt que está sendo destruído. No caso da Figura 4.2.S indica justamente o contato (transição) entre o álbico, parte mais amarelada da foto (lado esquerdo), com o $\mathrm{Bt}$, com maior concentração plásmica, lado direito da foto.

No caso da Figura 4.2.T, também indicando a transição $\mathrm{E} / \mathrm{Bt}$, observa-se o álbico com fundo matricial mais amarelada (tornando quase toda a foto) e o argílico com fundo matricial mais avermelhado. Observe a maior concentração de nódulos ferruginosos na porção do $\mathrm{Bt}$ ainda não destruídos enquanto que no álbico ficaram apenas alguns testemunhos destes nódulo. Por sua vez a Figura 4.2.U indica o Bt num fundo matricial massépico. Note a ausência de argilans tanto nos canais como nos fendilhamentos.

A destruição parcial do quartzo no horizonte E pode ser observado na Figura 4.2.V assim como a destruição parcial do nódulo de ferro na transição E/Bt (Figura 4.2.X). 
Figuras 4.2.

Fotomicrografias de seção delgada dos horizontes dos perfis T1 e T4 

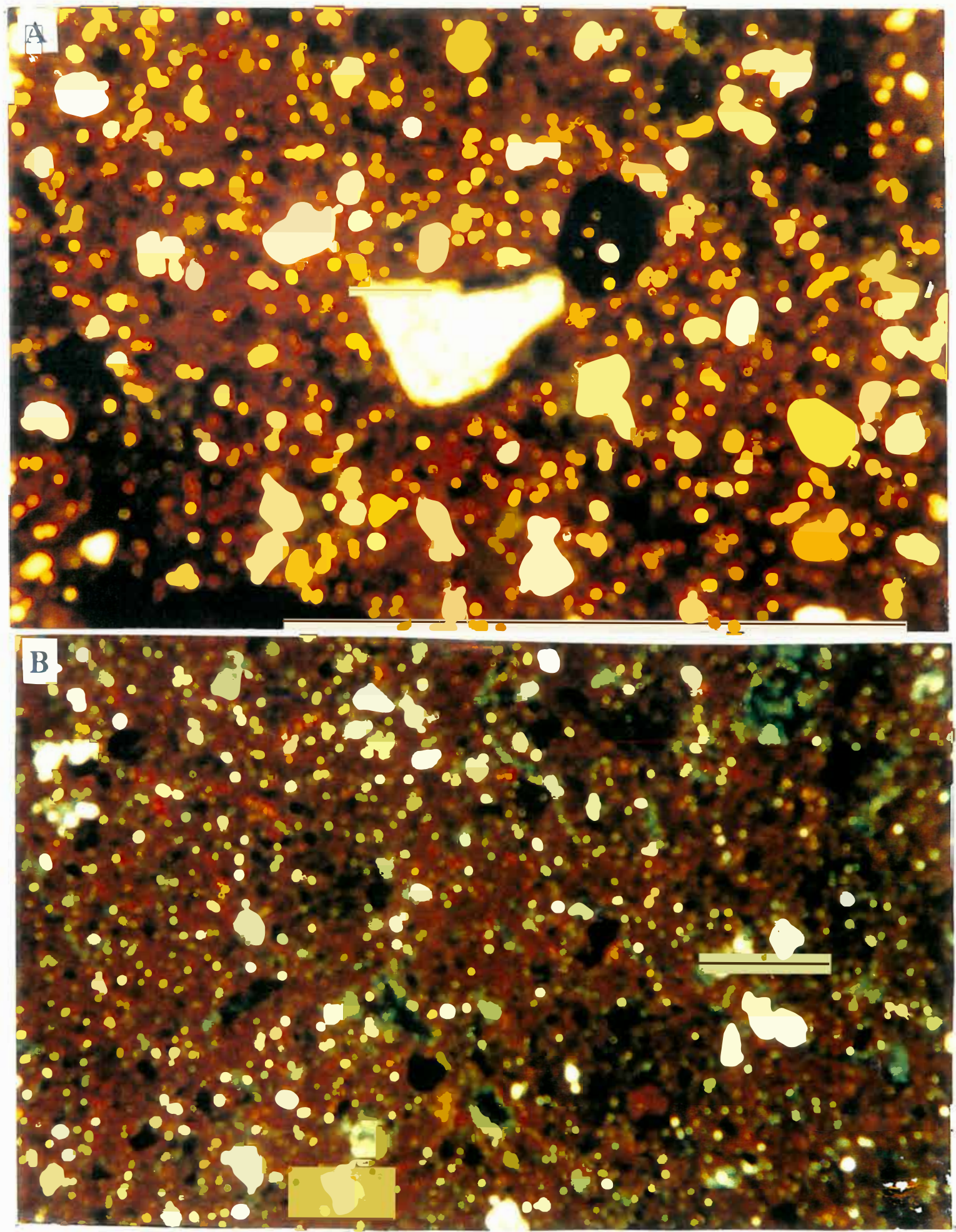

Figuras 4.2. (A) Estrutura plásmica isótica do $\mathrm{Tl}$ com litorrelíquias de bonecas de sílex no Ap: (B) Estrutura isótica ou ligeiramente undúlica no Btl, distribuição de base aleatória associada a concèntrica. 

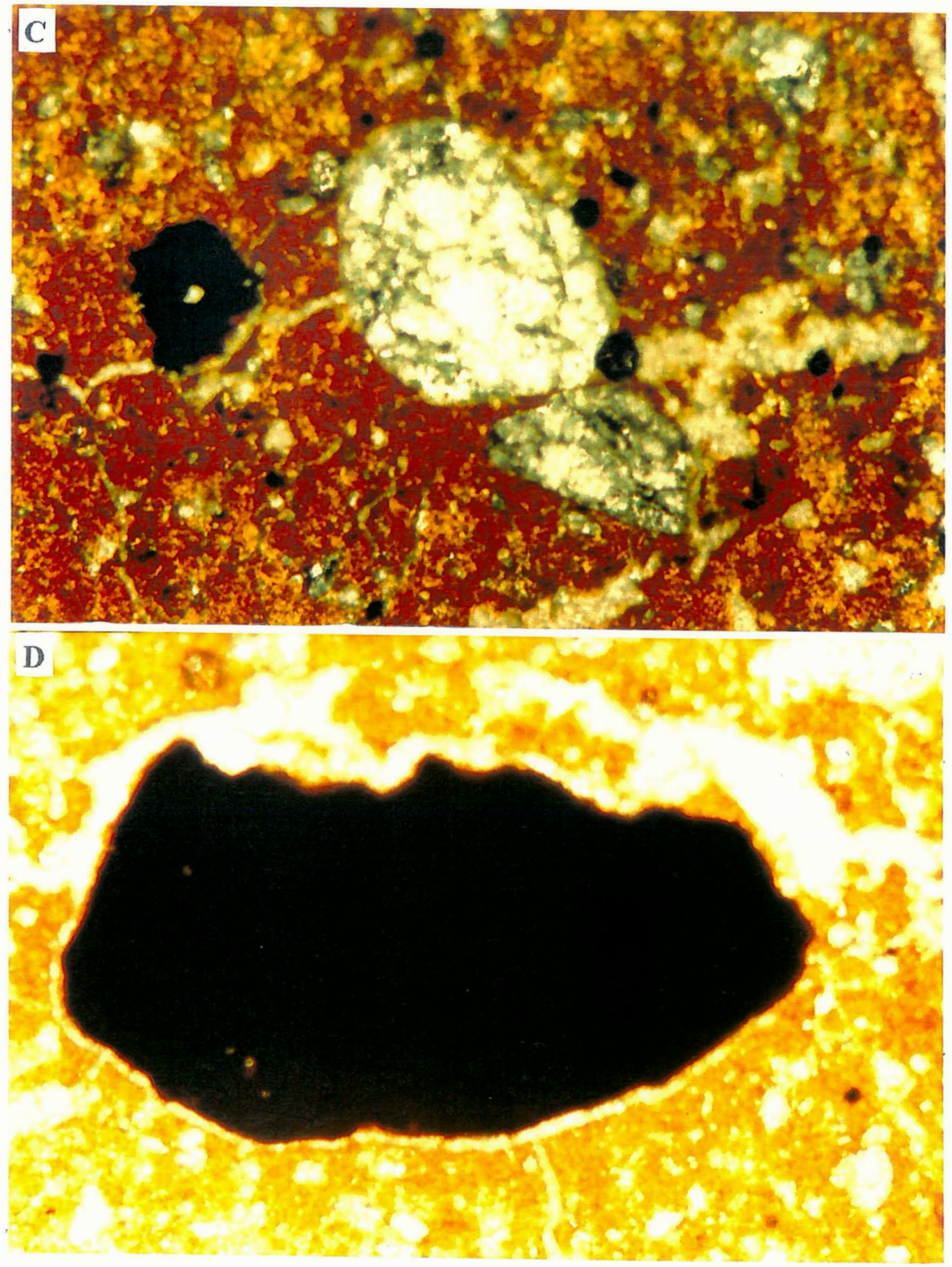

Figuras 4.2. (C) Fracionamento do quartzo e nódulo concêntrico de Fe com microquartzo no centro no Btl do TI: (D) Nódulo de Fe-Mn cujos contomos estão se desmanchando pelo hidromorfismo. 

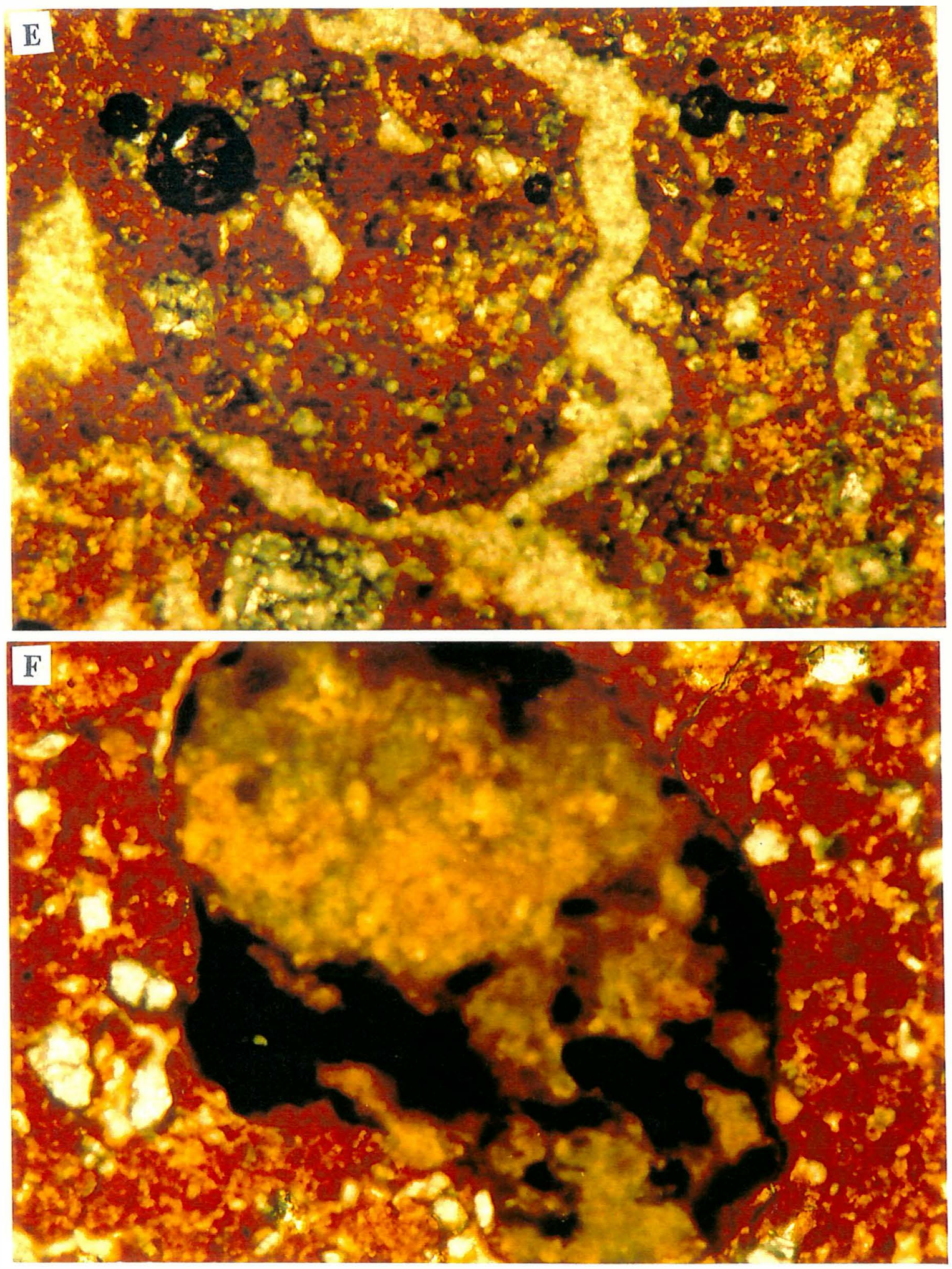

Figuras 4.2. (E) Microagregados coalescentes, nódulos "in situ", fissuras e rachaduras por dessecação, no Btl-T1; (F) Nódulo isotrópico preto (5R2/1, deferrificando-se por hidromorfismo no Bt2-w no TI. 

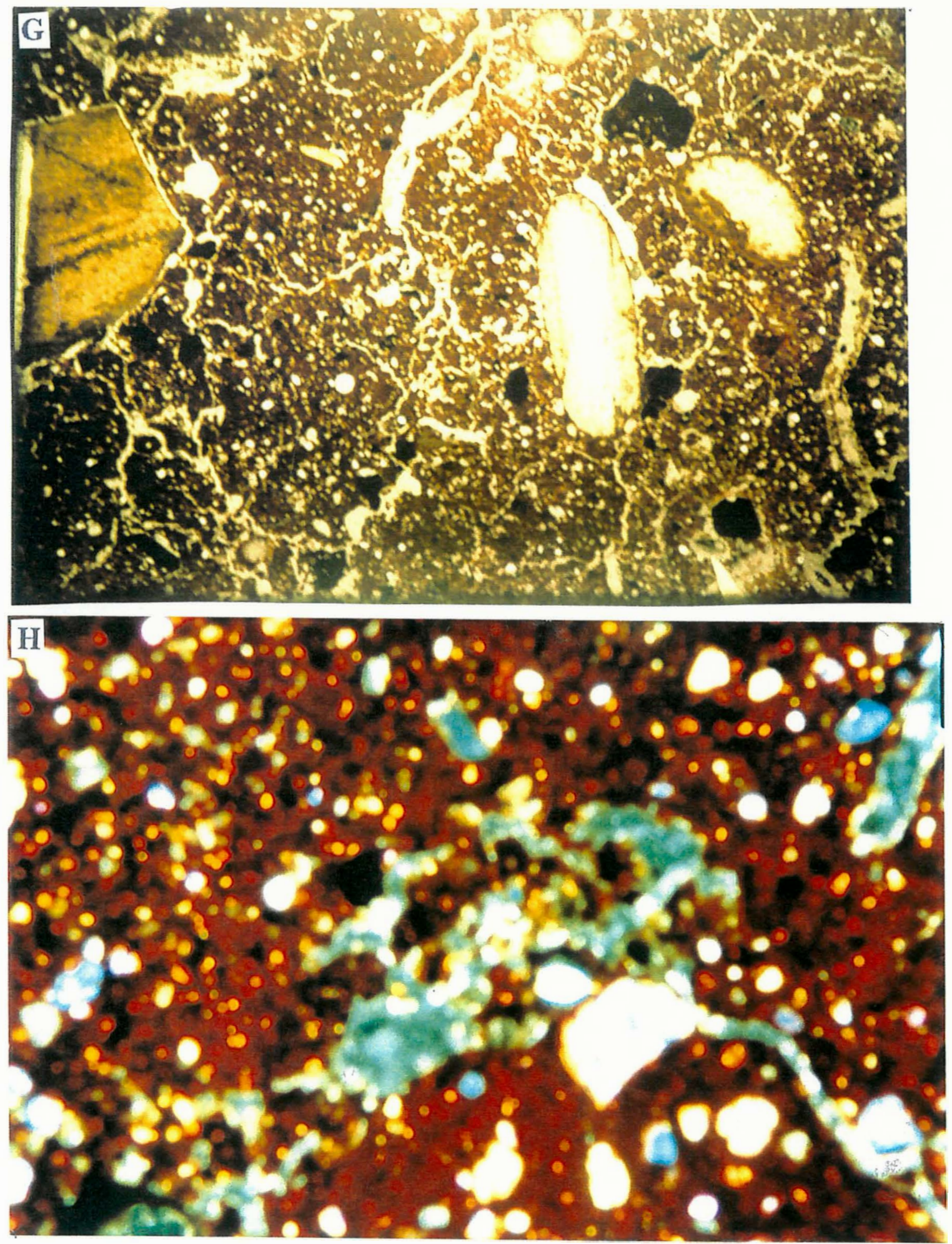

Figuras 4.2. (G) Projeção de lâmina delgada do Bt3 do T1. Nota-se aumento de bonecas de sílex e porosidade fissural: (H) Fissuração irregular. devido à dessecação. Abundância em microquartzo e nódulos. 

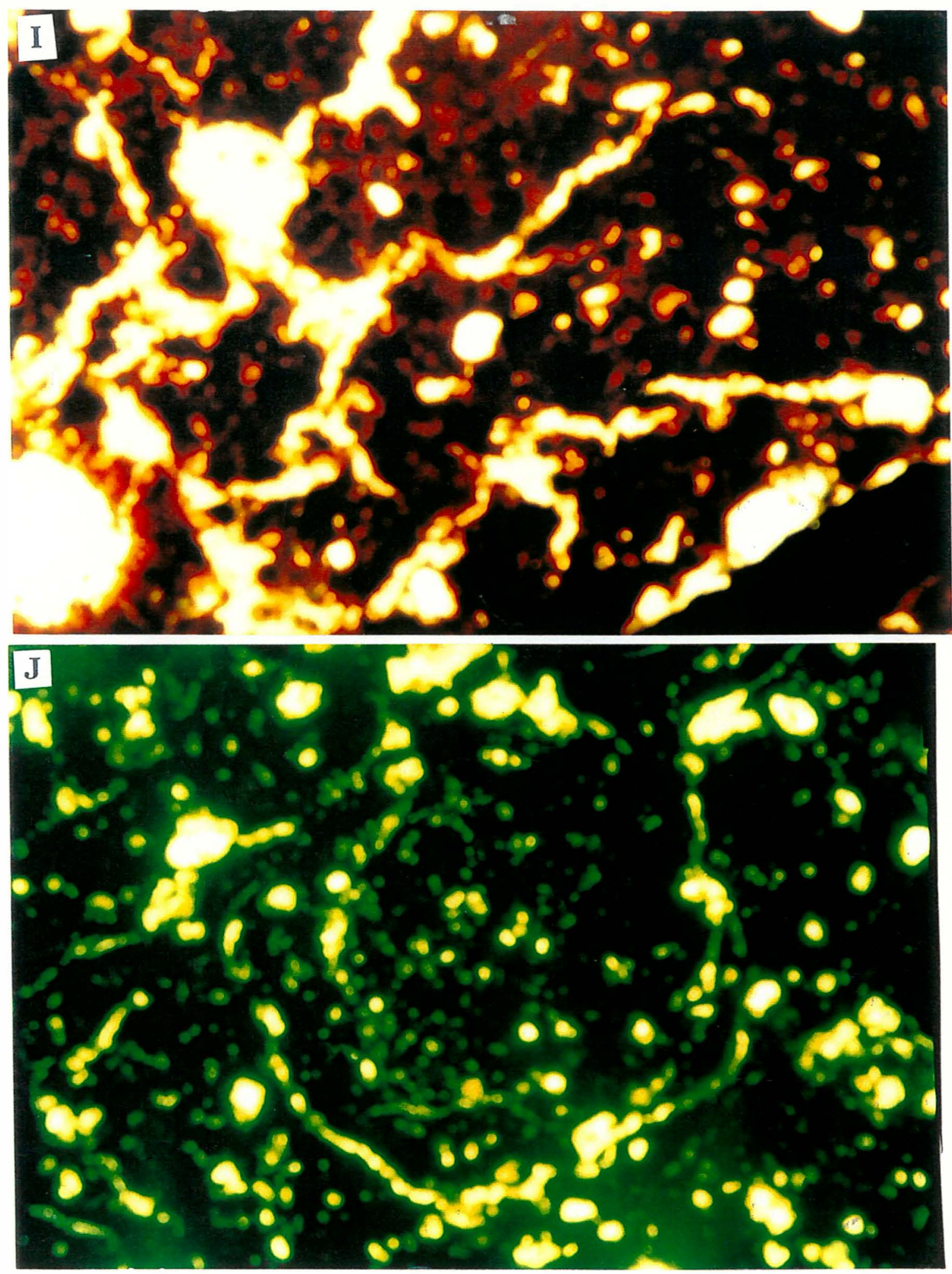

Figuras 4.2. (I) Associação de fïssuras obliquas "skew planes" e rachaduras "craze planes" evidência de dessecação; (J) Pedotúbulo preenchido com microquartzo (filtro verde, 50x) no Bt3 do T1. 


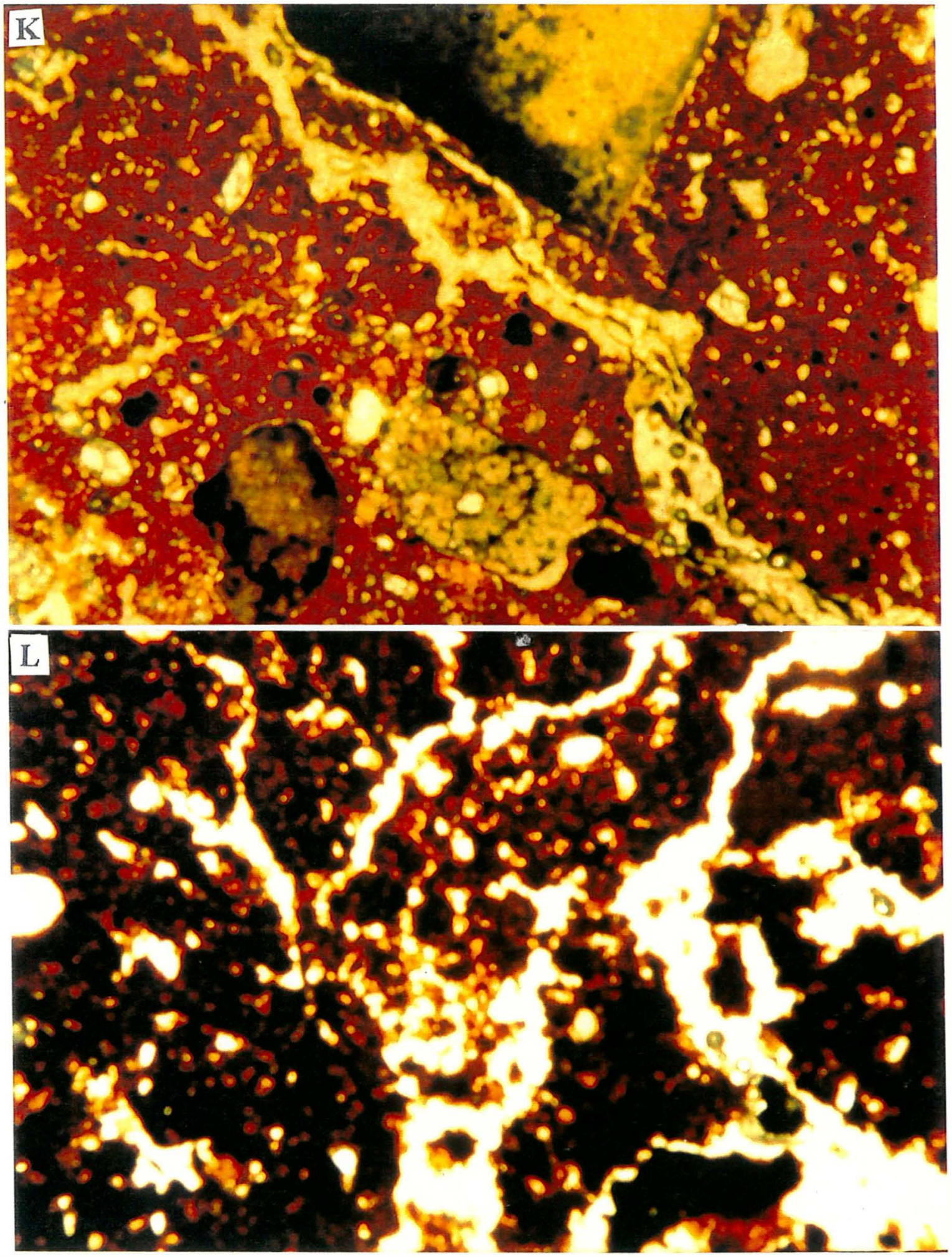

Figuras 4.2. (K) Fissuras irregulares resultantes de contração de cor vermelho-escuro do Bt2-w do T1; (L) microagregação incipiente com microfissuras de cavidades policôncavas em processo de latossolização no Bt2-w. 

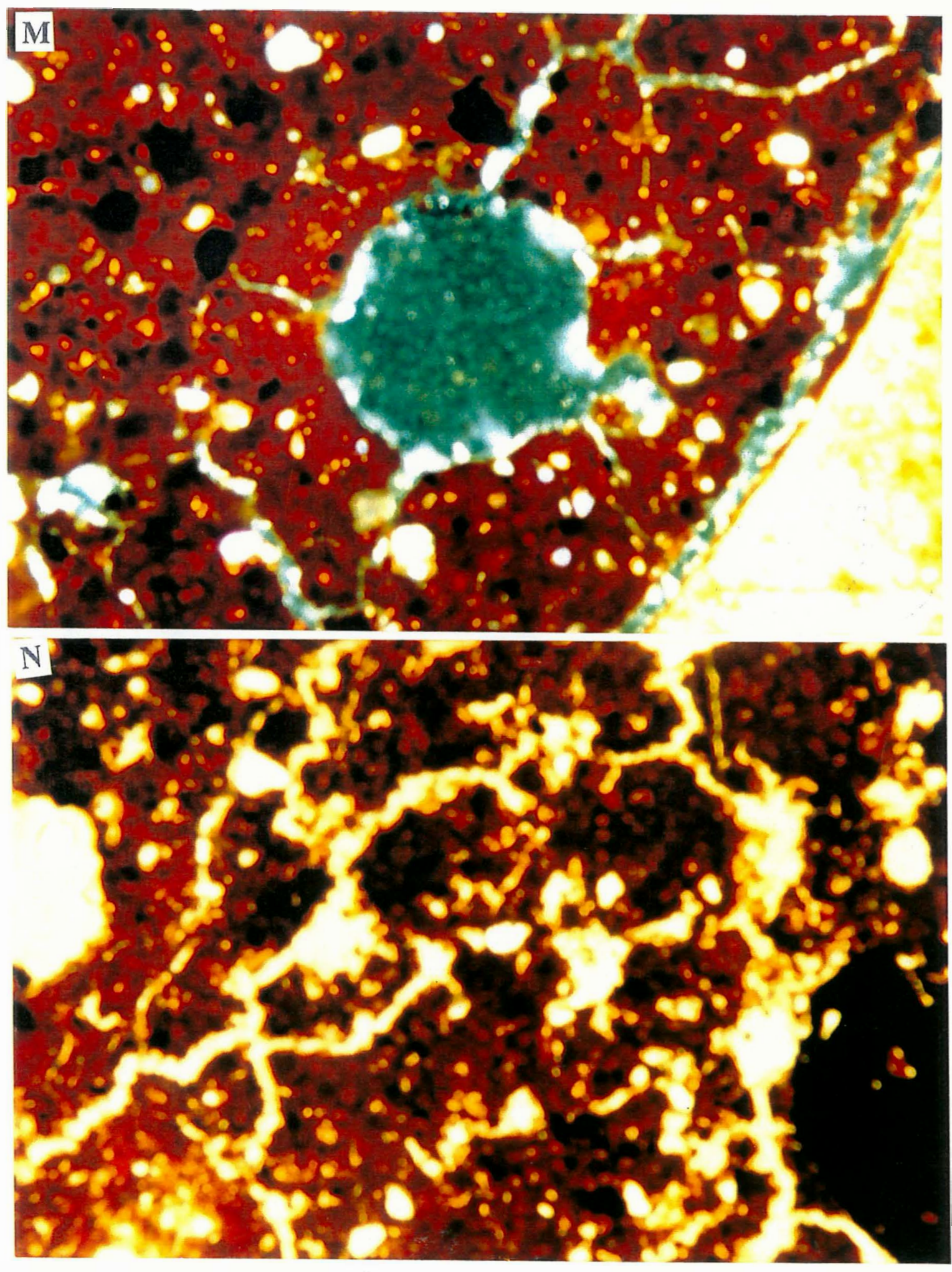

Figuras 4.2. (M) Bioporo associado a ortofissuras oblíquas resultante da atividade biológica no Bt3; (N) Fissuração oblíqua, contornando um microagregado, com fundo matricial apresentando cavidades policớncavas. 


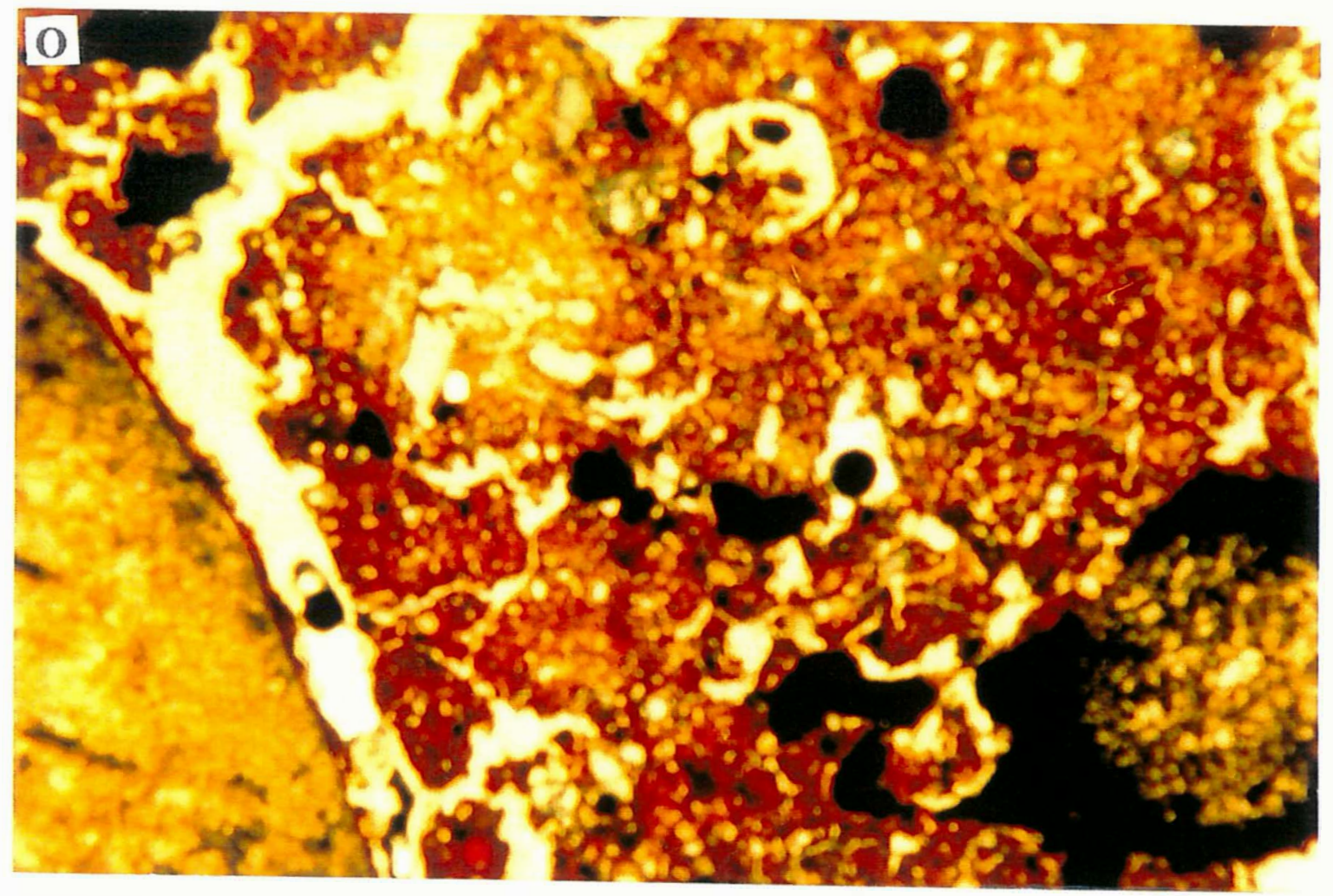

Figuras 4.2. (O) Rachaduras "craze planes", processo de ferruginação e maior porosidade fissural no Bt3 do Tl. 


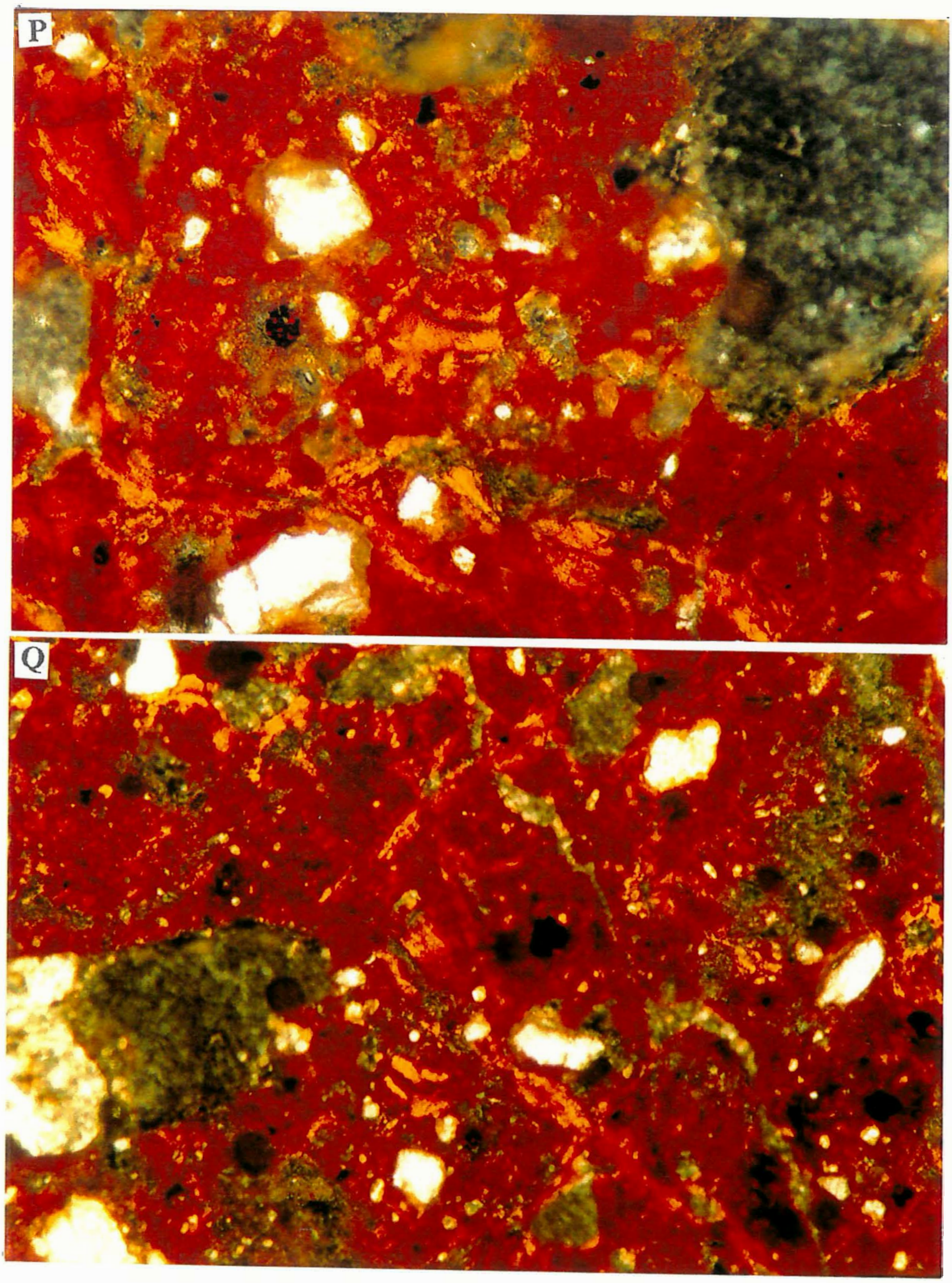

Figuras 4.2. Fotomicrografia de seção delgada com nicois cruzados do horizonte Bt2-w do T1. (P) Argilans associados a canais e pápulas; (Q) Concentração plásmica e argilans (aumento 200:) 


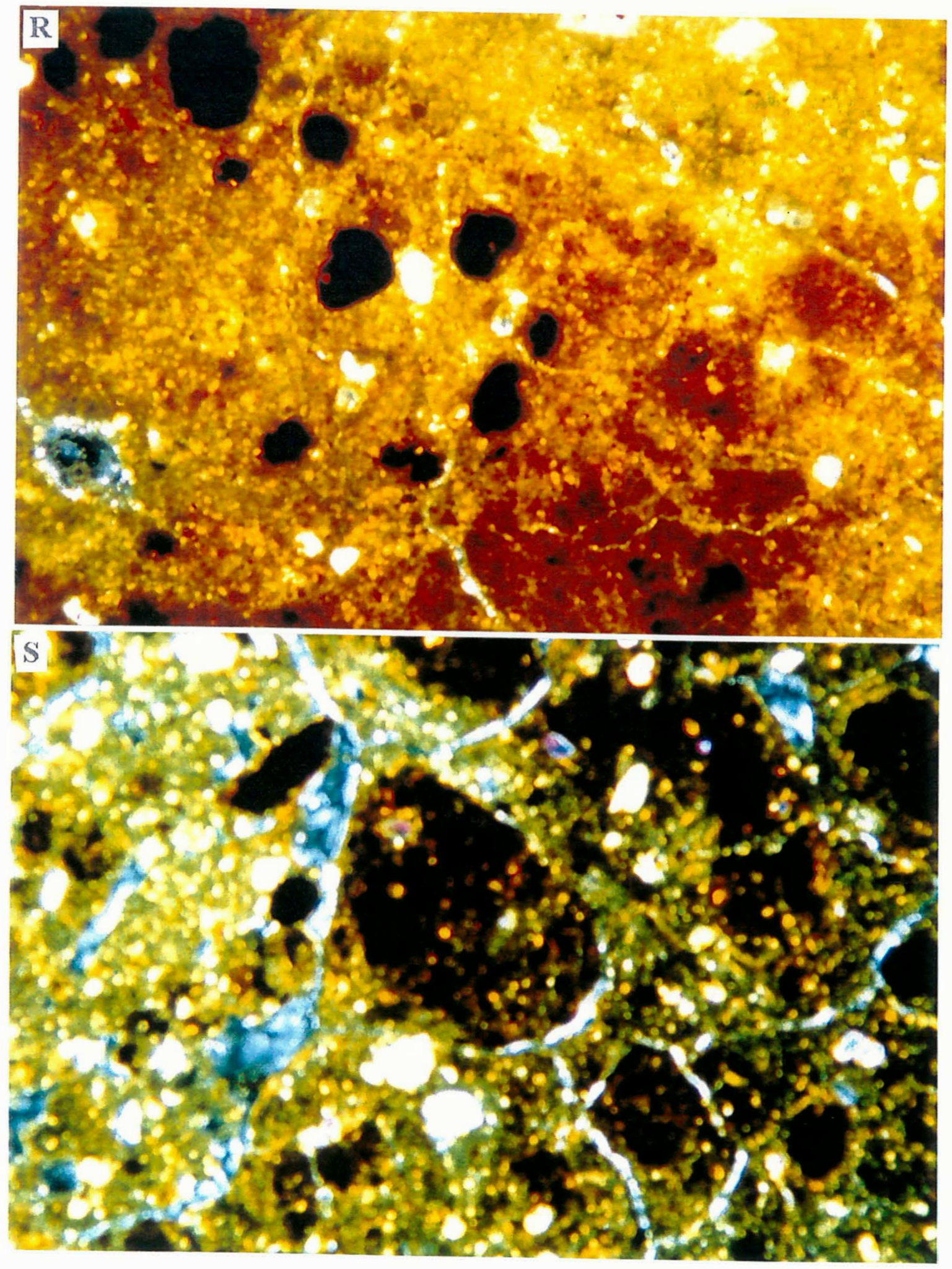

Figuras 4.2. R. Horizonte álbico do $\mathrm{T} 4$ com fundo matricial mais amarelado e concentrações mais argilosas (cor mais avermelhada), testemunho do Bt.; 4.2.S. Contato E/Bt do T4, o álbico ocupa parte esquerda da foto. 

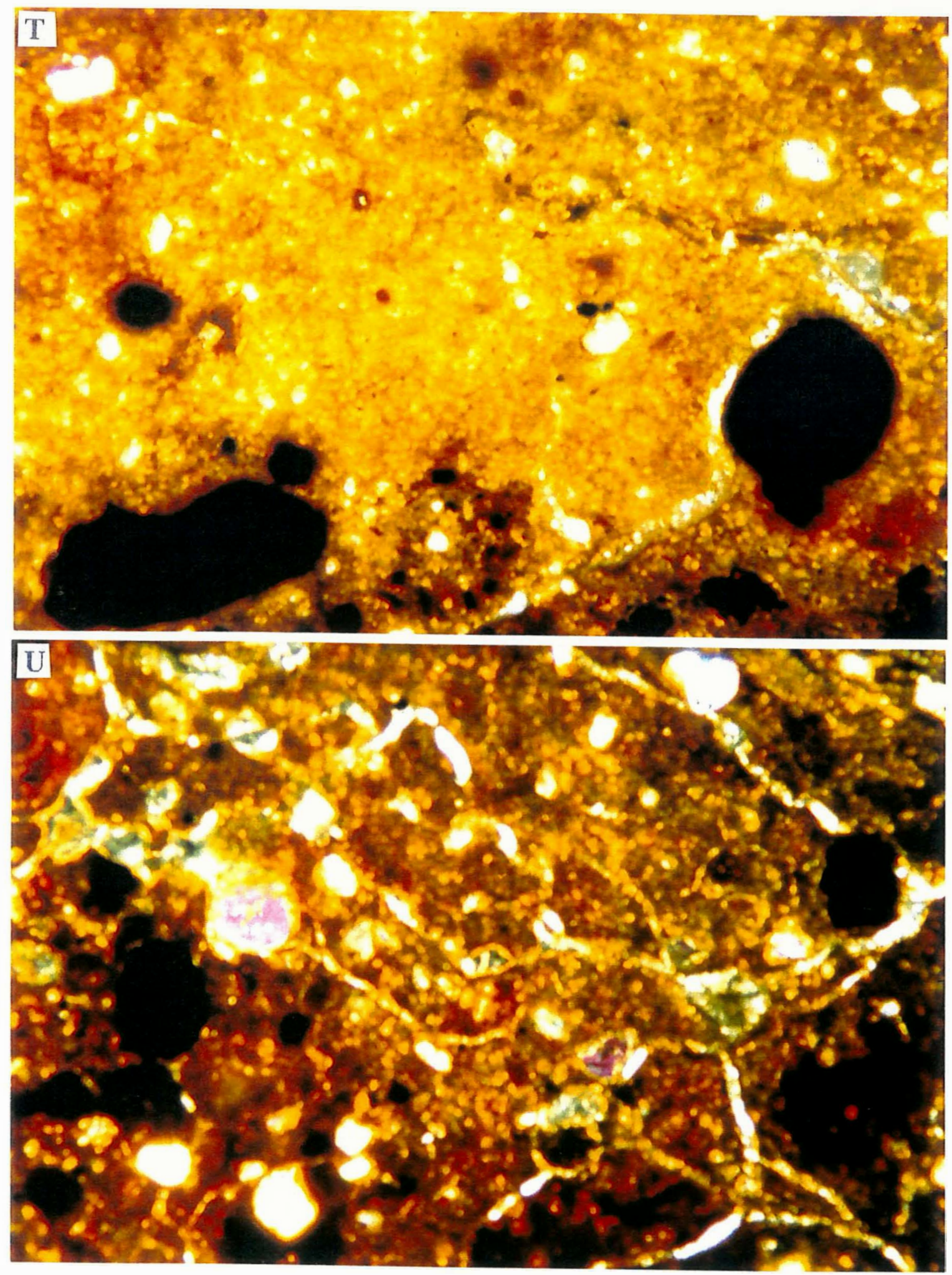

Figura 4.2 T. Contato $\mathrm{E}$ (cor mais amarelado) e o $\mathrm{Bt}$ (cor mais avermelhada) do $\mathrm{T} 4$. Note maior concentração dos nódulos ferruginosos no Bt. Os pequenos nódulos no $\mathrm{E}$ são testemunhos do Bt: 4.2.U. Horizonte $\mathrm{Bt}$ do $\mathrm{T}$ t. Ausência de argilans nos canais e fissuras. 

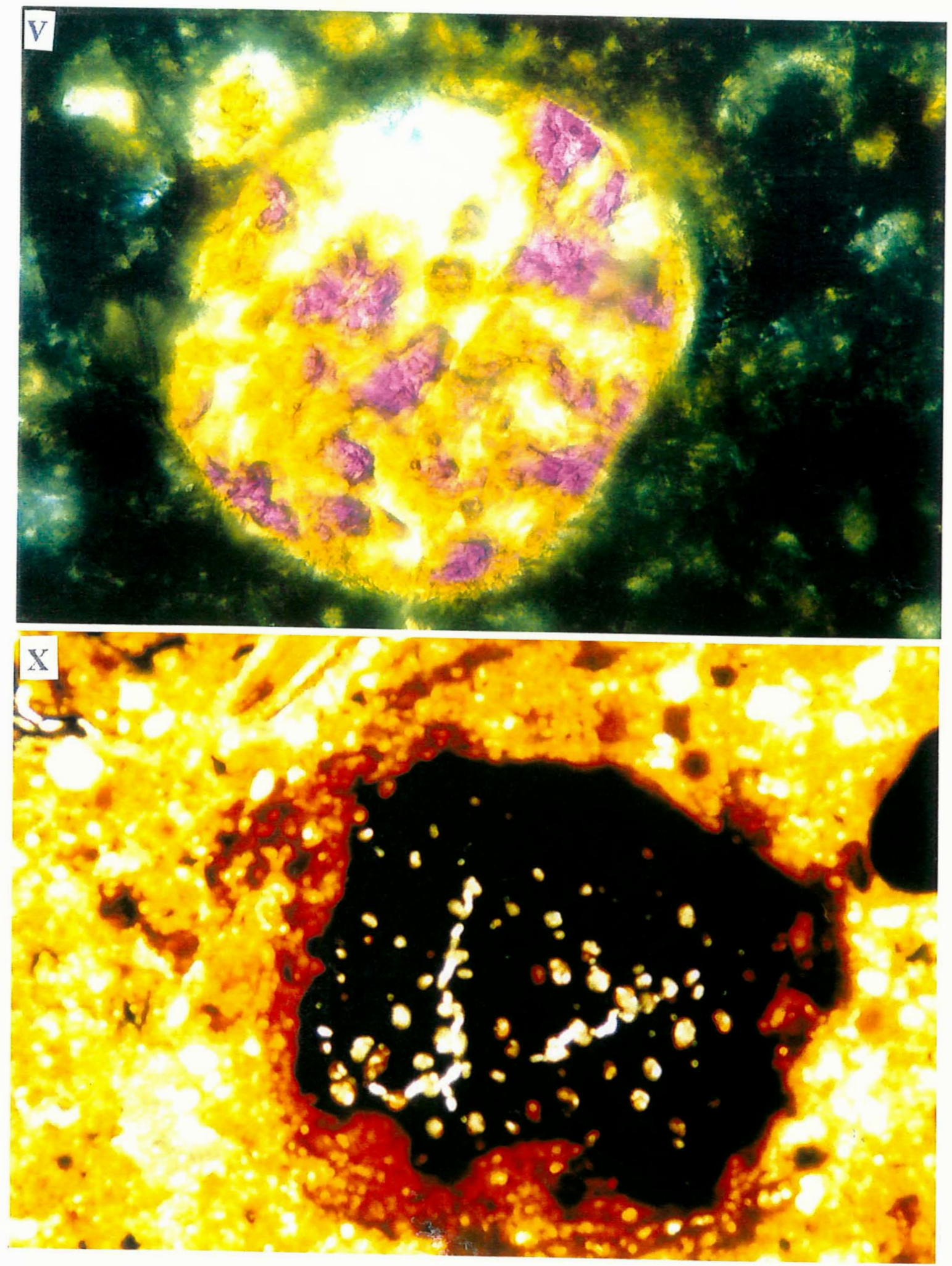

Figura +.2.V. Destruição parcial de gránulos de quartzo no álbico do $T+$ assim como destruição parcial do nódulo de ferro também no álbico $(\mathrm{X})$. 


\subsection{Propriedades físicas}

As variações de umidade do solo e porosidade ao longo da seqüência T1 a T4, evidência uma alta anisotropia vertical entre os horizontes superficiais e subsuperficiais (Tabela 4.2). De maneira geral os horizontes transicionais dos perfis 2 ao 4 representam as zonas de máximo incremento da densidade do solo e máxima redução na porosidade. Para o T2 a densidade no AE e EB é de 1,82 e 1,77 respectivamente, baixando para 1,62 no Bt1. No caso do T3 os valores são de 1,52 e 1,55 nos horizontes $\mathrm{AE}$ e E passando para 1,53 no Bt; e no $\mathrm{T} 4$ de 1,30 no horizonte $\mathrm{E}$ passa para 1,45 no $\mathrm{Bt}$. Tais variações são também evidenciadas pelas curvas de retenção indicadas na Figura 4.3 , que vem refletir o teor de argila de tais camadas, inclusive com menor quantidade nos horizontes $\mathrm{E}$.

Os resultados das maiores densidades nos horizontes transicionais, associado à presença de pontuações de gleização, são compatíveis, portanto, com a saturação temporária de água nestes horizontes o que pode causar maior permanência da água em tais posições ou "lençol de água em suspensão" (Bouma, 1983).

Os dados das análises granulométricas dos perfis 1 a 4 indicam uma dominância da fração argila, principalmente nos horizontes $\mathrm{Bt}$ e nas camadas mais profundas. Os teores deste separado nos horizontes Bt do T1 estão na faixa de 73 e $79 \%$, no T2 de 66 a 74 no T3 de 67 a 71 e no T4 de 67 a $73 \%$ (Tabela 4.3).

Neste caso nota-se uma grande similaridade entre os perfis estudados. Em maior profundidade também as variações não são grandes neste separado do solo, cujos teores ficam na faixa de 60 a 79\%. A relação textural B/A destes perfis é suficiente para caracterizar o horizonte B como textural (EMBRAPA, 1981) ou horizonte argílico no Soil Taxonomy (Soil Survey Staff, 1990).

Os teores de silte destes perfis, contrariamente a maioria dos solos tropicais, são relativamente elevados principalmente para os horizontes $\mathrm{Bt}$ dos perfis 2 , 3 e 4 (faixa de 14 a 23\%). O teor de areia total tende a decrescer em profundidade principalmente entre os horizontes $\mathrm{A}$, com maior teor de areia, e os horizontes $\mathrm{B}$, com 


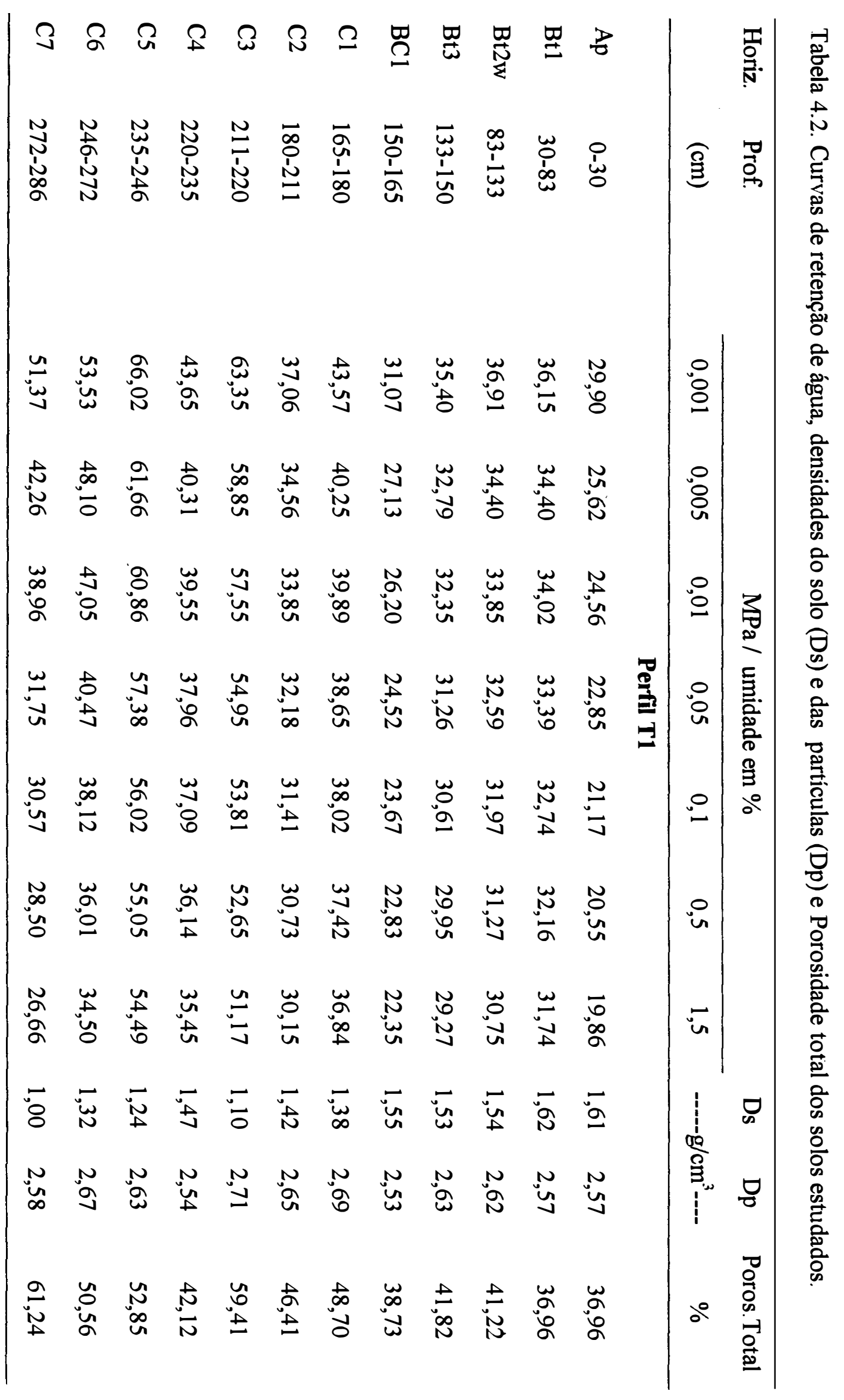




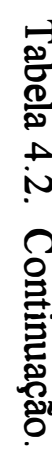

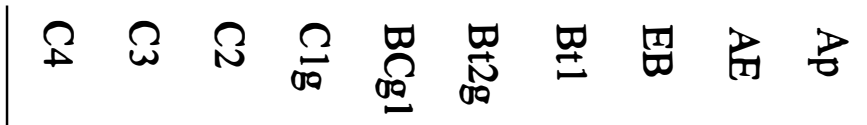

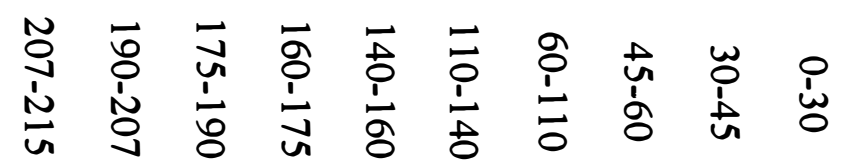

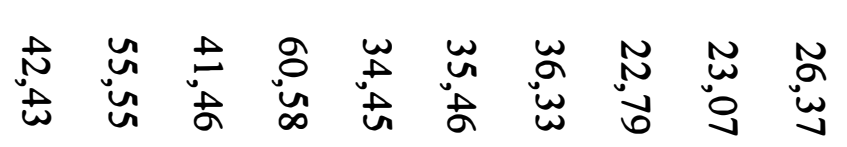

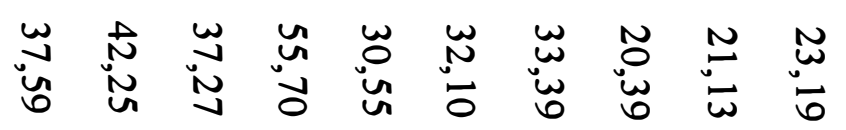

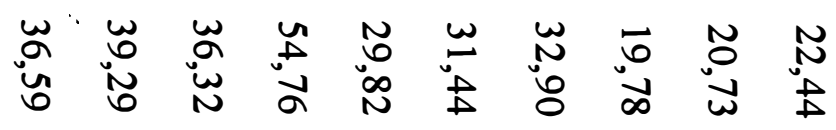

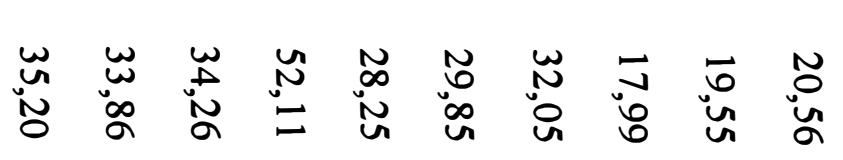

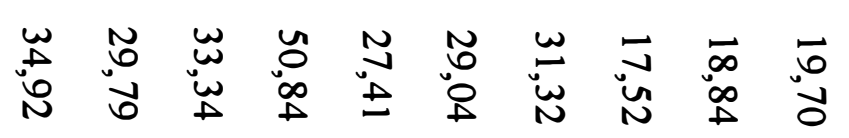

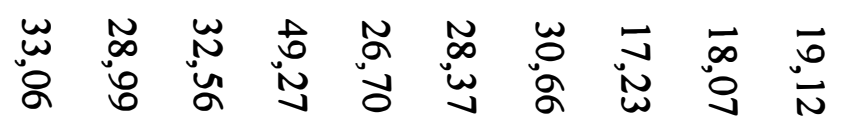

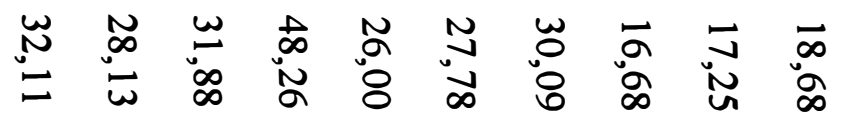

$$
\begin{aligned}
& \text { 秥 }
\end{aligned}
$$

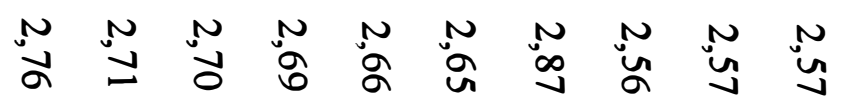

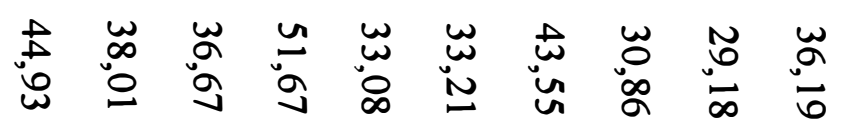

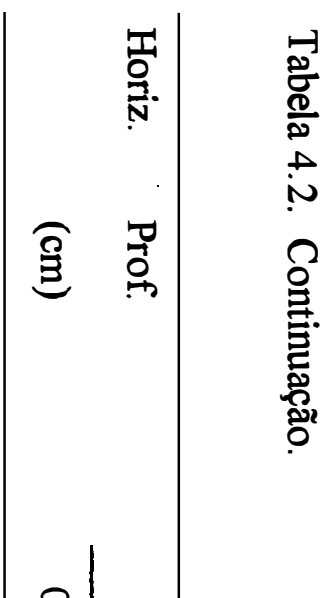




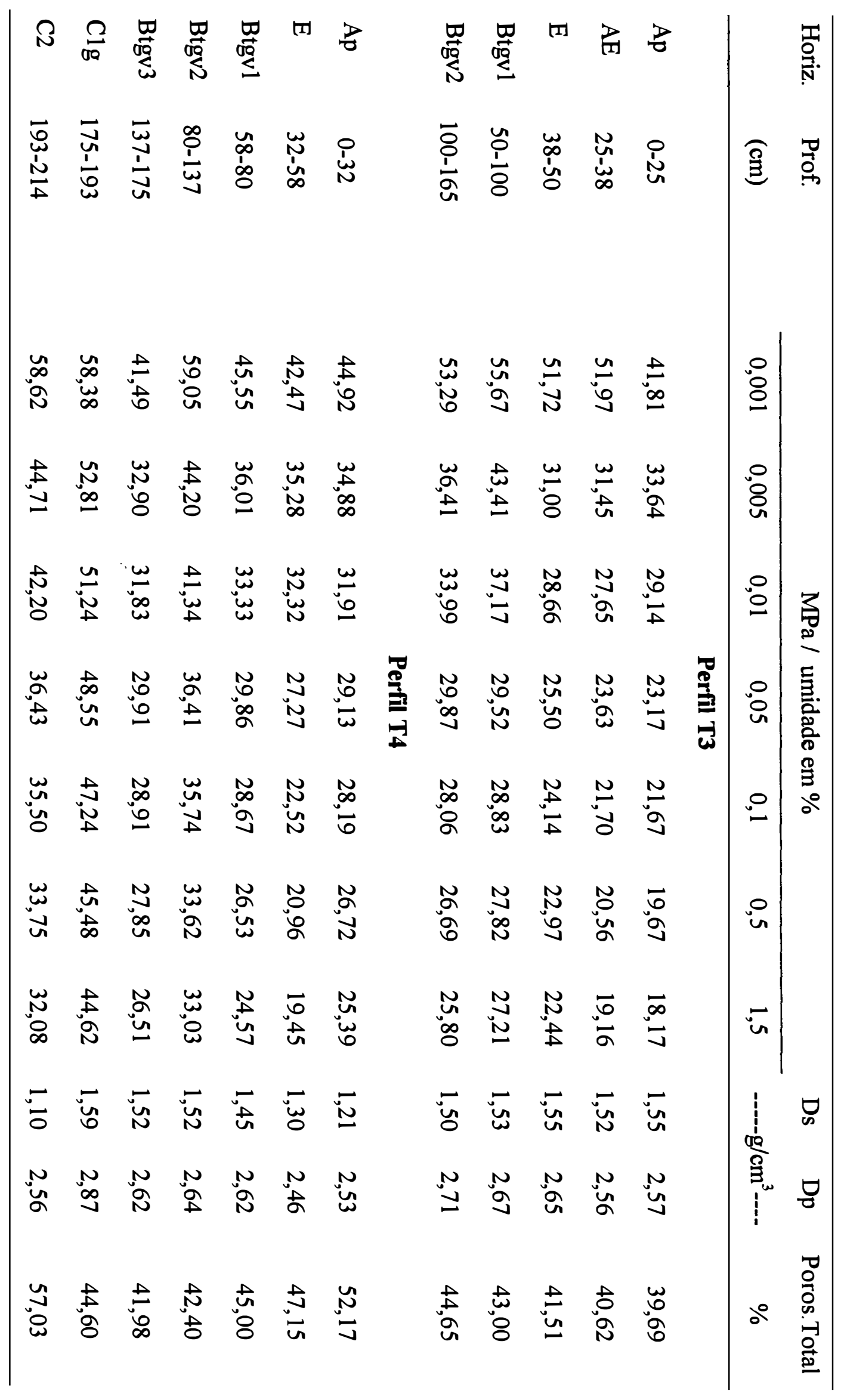



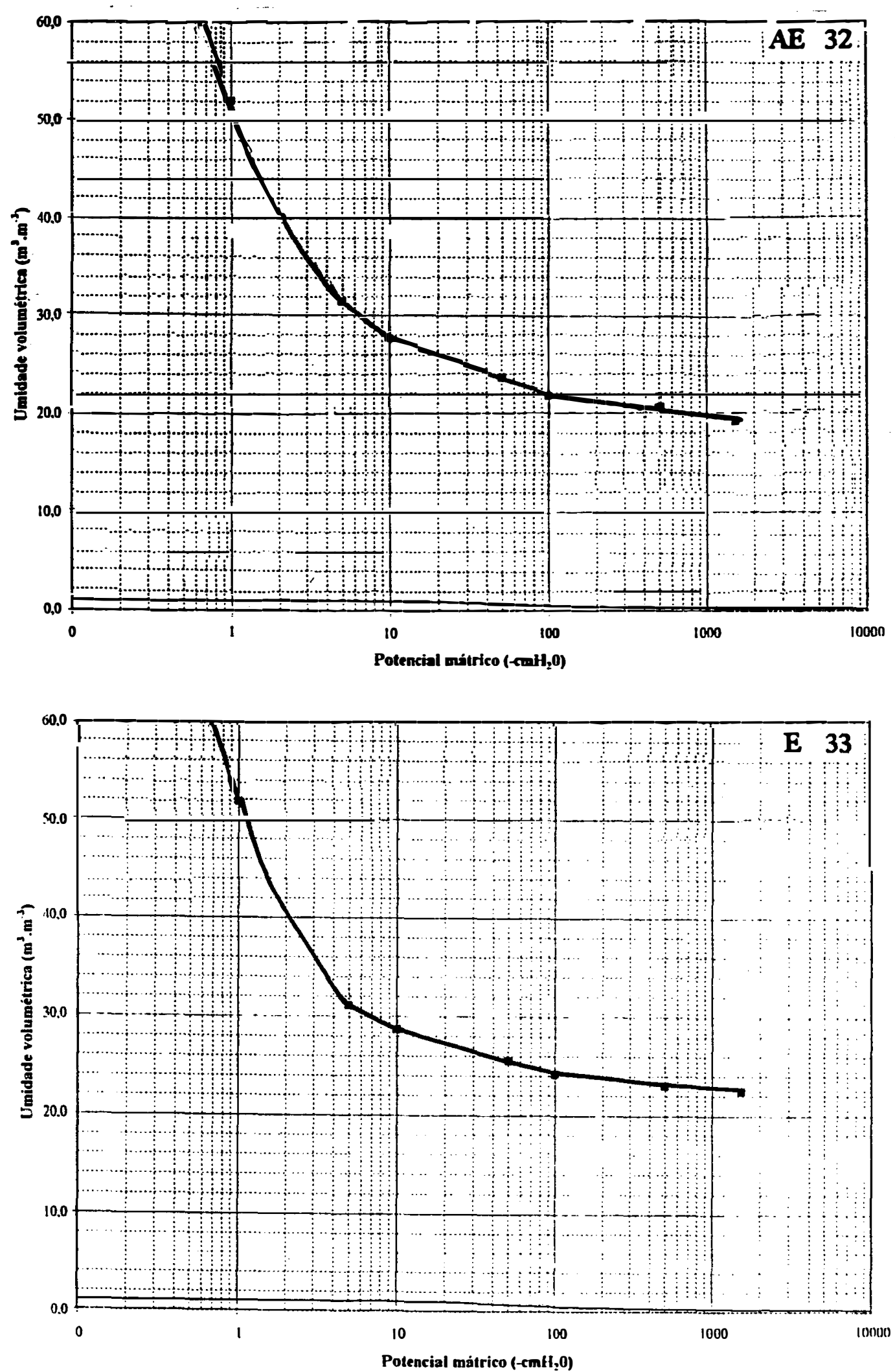

Figura 4.3. Curvas de retenção de água dos perfis T3 e T4. 

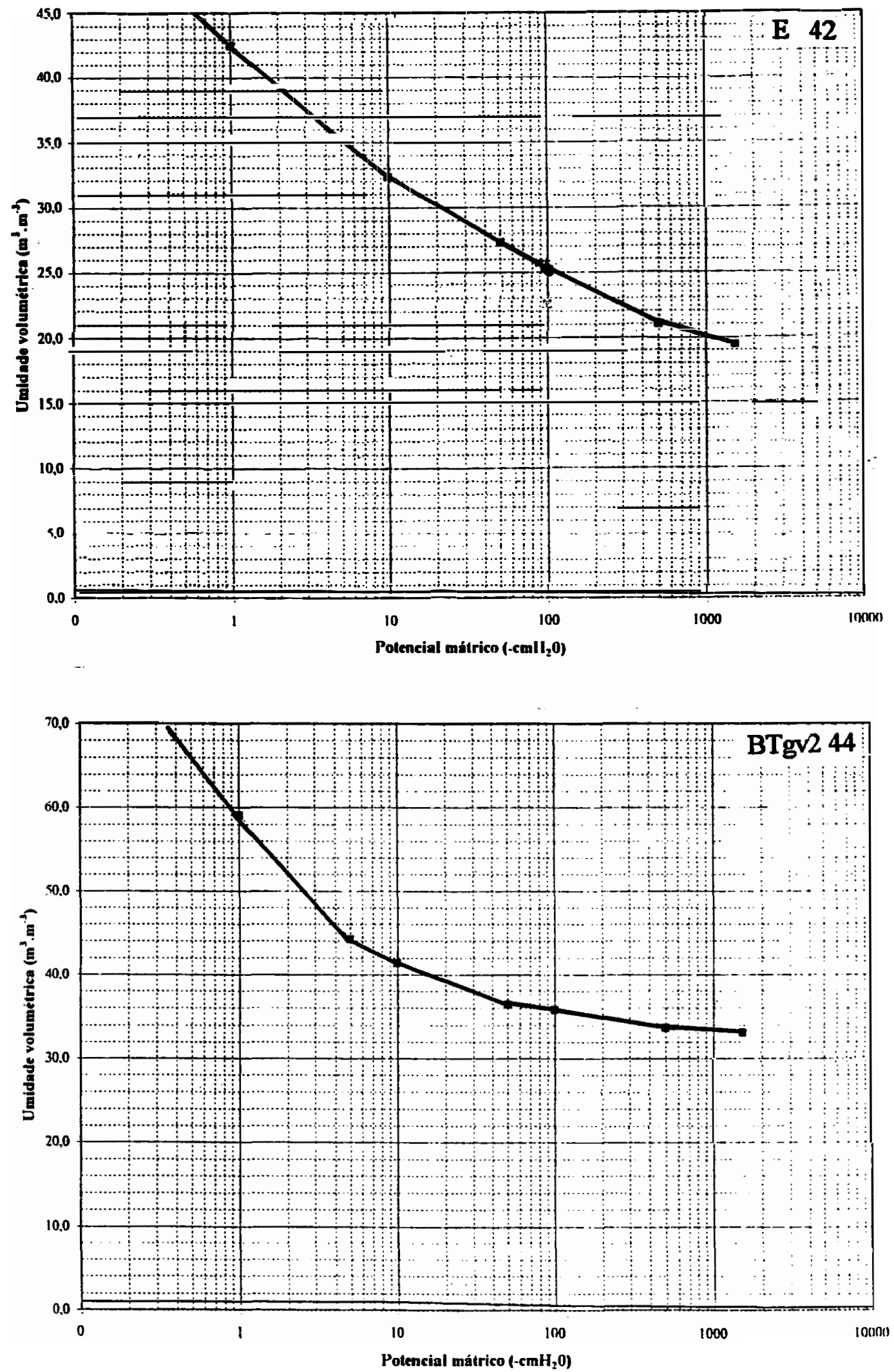

Figura 4.3. Continuação. 


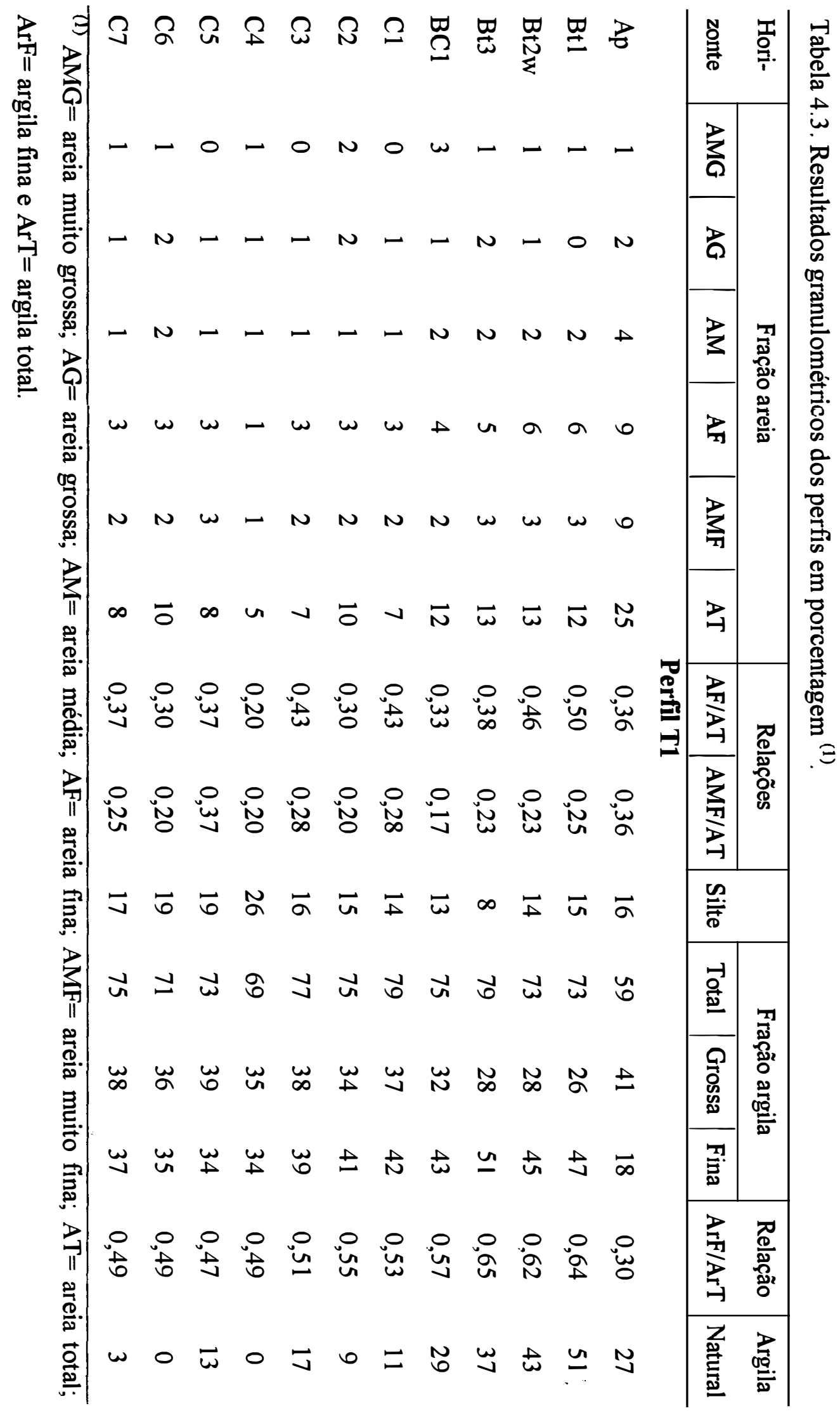




\begin{tabular}{|c|c|c|c|c|c|c|c|c|c|c|c|c|}
\hline$\AA$ & $\tilde{\omega}$ & N & $\frac{\Omega}{10}$ & $\begin{array}{l}\mathscr{O} \\
\mathbb{Q}^{\circ}\end{array}$ & $\underset{\infty 0}{\underset{N}{W}}$ & $\stackrel{\mathscr{W}}{\Xi}$ & $\mathbb{H}$ & $\vec{H}_{\mathrm{H}}$ & $\frac{B}{0}$ & & $\stackrel{N}{\frac{N}{6}}$ & $\begin{array}{l}\text { T. } \\
\text { ㄱ. }\end{array}$ \\
\hline$N$ & - & - & - & $N$ & 0 & - & - & • & 0 & & $\frac{2}{a}$ & \\
\hline$N$ & $\omega$ & $\omega$ & u & $\omega$ & $N$ & - & $N$ & $N$ & $N$ & & 足 & \\
\hline$\omega$ & $N$ & $\omega$ & $\omega$ & $N$ & $N$ & $N$ & $\triangle$ & un & $\Delta$ & & $\frac{2}{3}$ & 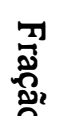 \\
\hline$a$ & $\Delta$ & $\omega$ & $\Delta$ & $\omega$ & u & u & 6 & $\vec{\omega}$ & $\vec{N}$ & & $B_{1}$ & $\frac{\rho}{\partial}$. \\
\hline$\omega$ & $N$ & $\Delta$ & $\omega$ & $N$ & $\omega$ & $\omega$ & $a$ & $\infty$ & $\checkmark$ & & $\frac{2}{3}$ & \\
\hline a & $\vec{N}$ & $\vec{\Delta}$ & $\vec{a}$ & $\vec{N}$ & $\vec{N}$ & $\vec{N}$ & $N$ & No & $\tilde{N}$ & & $\frac{2}{4}$ & \\
\hline$\stackrel{0}{w}$ & 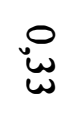 & $\stackrel{0}{N}$ & 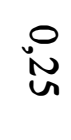 & 只 & $\stackrel{0}{\stackrel{0}{N}}$ & $\begin{array}{c}\circ \\
\stackrel{N}{N}\end{array}$ & $\stackrel{0}{ \pm}$ & $\begin{array}{l}0 \\
\stackrel{\perp}{*}\end{array}$ & $\begin{array}{l}\circ \\
\stackrel{\infty}{\infty}\end{array}$ & $\stackrel{9}{3}$ & $\frac{2}{3}$ & 邓 \\
\hline ๑。 & $\stackrel{0}{v}$ & N & $\frac{0}{6}$ & $\stackrel{0}{\beth}$ & $\begin{array}{l}0 \\
\text { N }\end{array}$ & $\stackrel{0}{N}$ & 冷 & 品 & 恼 & & $\frac{2}{3}$ & ర్లై \\
\hline N & 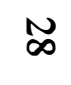 & w & $\vec{a}$ & $\vec{A}$ & $N$ & $\vec{A}$ & $\sqrt{0}$ & N & $\tilde{\alpha}$ & & 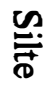 & \\
\hline$\stackrel{\nexists}{\perp}$ & g & ů & ஓ & $\stackrel{D}{ }$ & ฉ & $\vec{D}$ & ů & $\frac{1}{\infty}$ & $\vec{b}$ & & 엄 & \\
\hline$\underset{\perp}{\omega}$ & $\underset{N}{\omega}$ & $\stackrel{N}{A}$ & $\stackrel{\omega}{N}$ & $\tilde{N}$ & $\tilde{\alpha}$ & No & $N$ & $\stackrel{N}{\omega}$ & $\stackrel{\sim}{\omega}$ & & 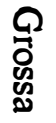 & 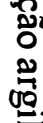 \\
\hline$\tilde{o}$ & $N_{\infty}$ & $\tilde{\alpha}$ & w & $\stackrel{A}{N}$ & 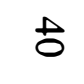 & 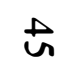 & w & N & N & & ד্: & \\
\hline $\begin{array}{l}\circ \\
\stackrel{0}{ \pm}\end{array}$ & $\begin{array}{l}\circ \\
\stackrel{ \pm}{*}\end{array}$ & in & 을 & in & $\begin{array}{l}\circ \\
\stackrel{2}{9}\end{array}$ & $\begin{array}{l}0 \\
\text { 임 }\end{array}$ & 足 & in & 号 & & 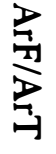 & 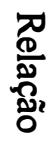 \\
\hline$\vec{N}$ & $\infty$ & 0 & న & N & $\vec{A}$ & w & No & $\vec{a}$ & $\vec{A}$ & & 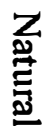 & 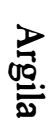 \\
\hline
\end{tabular}




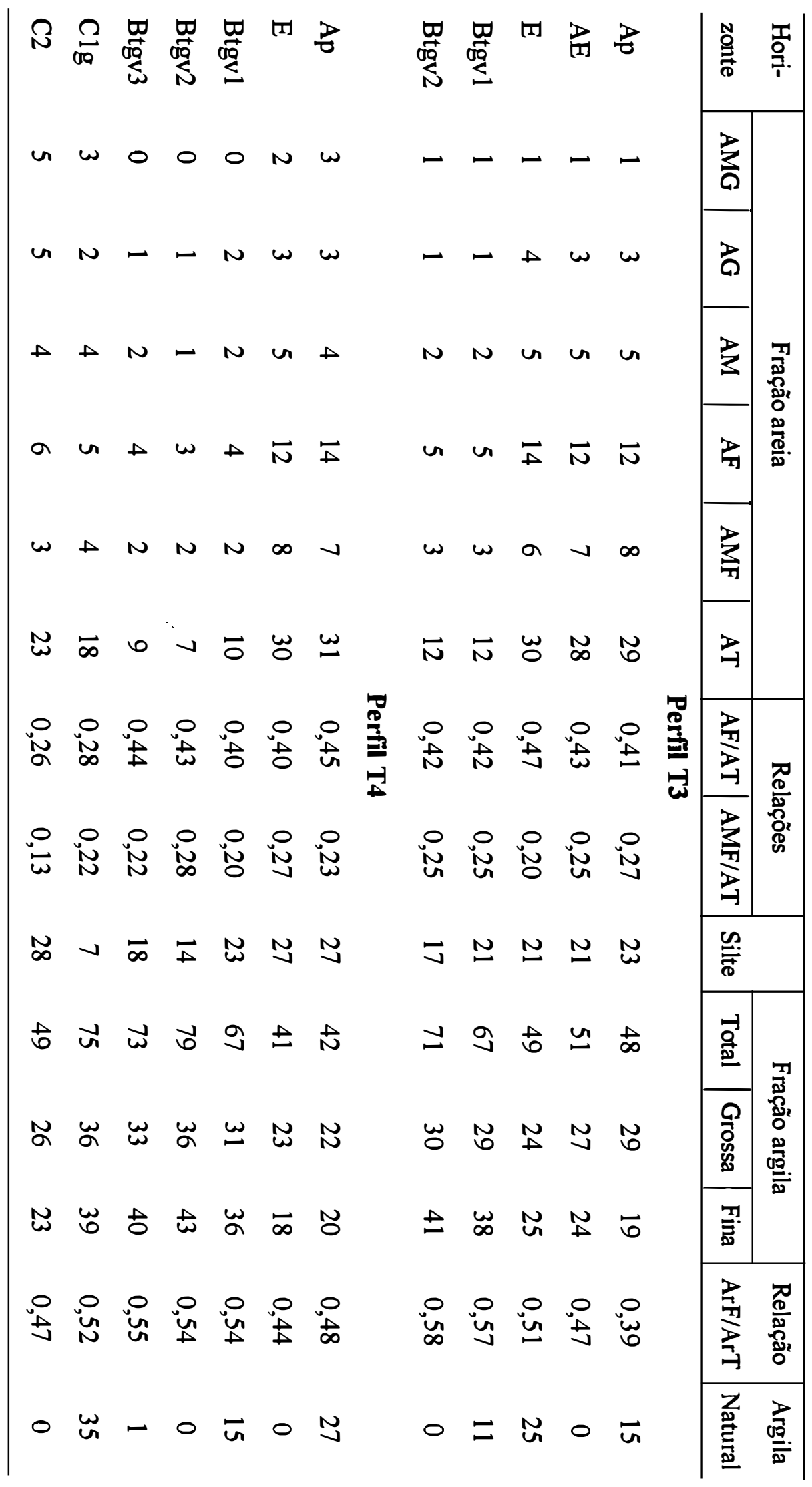

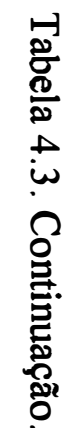


menor. Tais teores são heranças do próprio argilito, constituinte do material de origem destes solos.

O fracionamento da areia revelou um predomínio da fração areia fina principalmente nos horizontes A e B sendo seguido pela fração areia muito fina. As relações areia fina / areia total e areia muito fina / areia total são muito similares nos horizontes A e B. (Figura 4.4) para todos os perfis estudados.

Quebras acentuadas dessas razões (normalmente acima de 100\%) ao longo do perfil, tem sido utilizados como critério para identificação de discontinuidades litológicas ou efeitos deposicionais (Brinkman, 1979; Birkeland, 1984; CabreraMartínez et al., 1989). Os resultados destas relações, para todos os perfis analisados, sugerem que o material de origem destes solos é uniforme, não havendo camadas deposicionais superficiais; o que seriam indicadas por eventuais quebras de seqüência.

Os cálculos estatísticos da distribuição das areias permitem diferenciar as litologias no campo. Segundo esta metodologia, materiais diferentes possuem uma distribuição distinta da fração areia (Peres Filho et al., 1980; Tremocoldi \& Steihardt, 1987; Vidal -Torrado, 1994). Em nosso caso o uso do programa "Phi" de Lier \& VidalTorrado (1992) permitiu observar que o desvio padrão dos quatro perfis estudados, são "pobremente selecionados", exceto no Ap do perfil T1 que é "bem selecionado". A simetria varia de negativa à muito negativa em todo os perfis, exceto nos horizontes $\mathrm{C} 4$ do perfil T1, (BCg)1 e C2 do perfil T2, que é "aproximadamente simétrica" e, sendo "positiva" no único horizonte $\mathrm{Clg}$ do perfil T2.

A curtose varia de "muito leptocúrtico" no horizonte Ap do perfil T1 ao "mesocúrtico" nos horizontes Ap dos perfis T2, T3 e T4. Os horizontes Bt1 dos perfis T1 a T4, variam de platicúrtico a muito platicúrtico em função da profundidade, mesmo assim, o perfil T2 apresenta-se como "mesocúrtico" nos primeiros $110 \mathrm{~cm}$ superficiais. Essas distribuições podem ser vistas na Figura 4.5 e no Apêndice 2.

É interessante observar que estes resultados são indicativos de que a gênese destes solos é mais influenciado pela ação dos processos pedogenéticos internos 

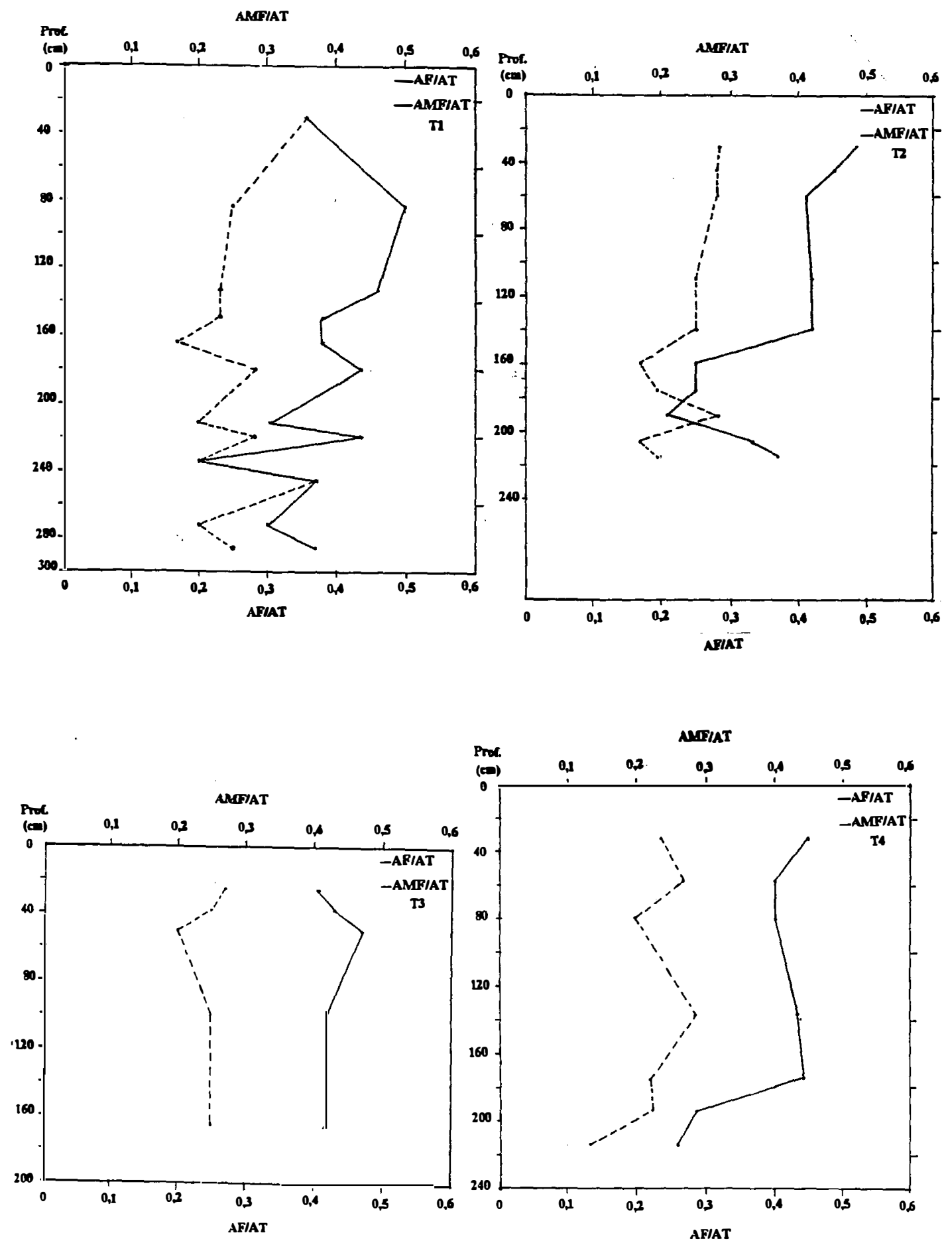

Figura 4.4. Relações da AF/AT e AMF/AT dos solos. 


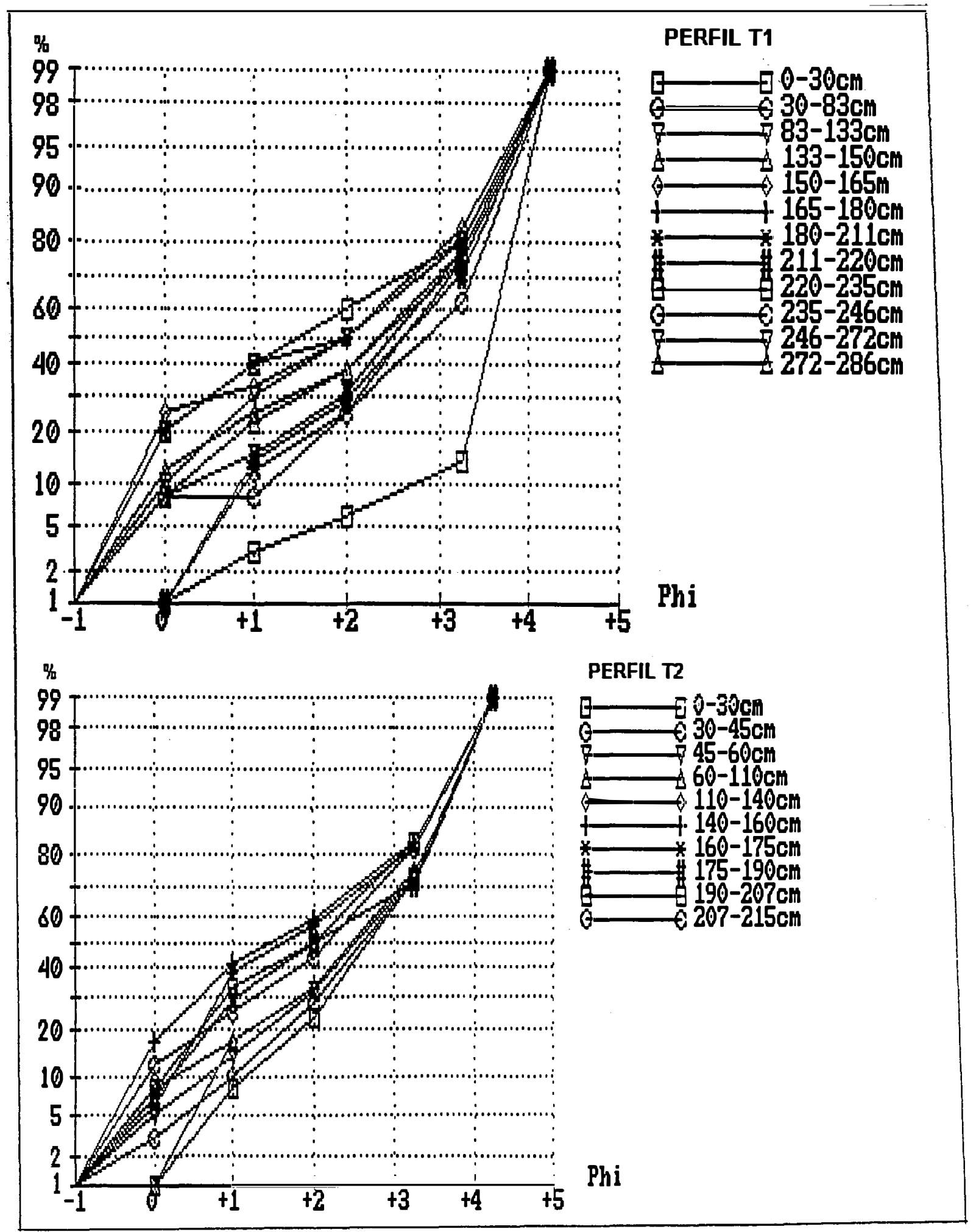

Figura 4.5. Distribuição estatística das 5 frações de areia referentes aos solos da catena. 


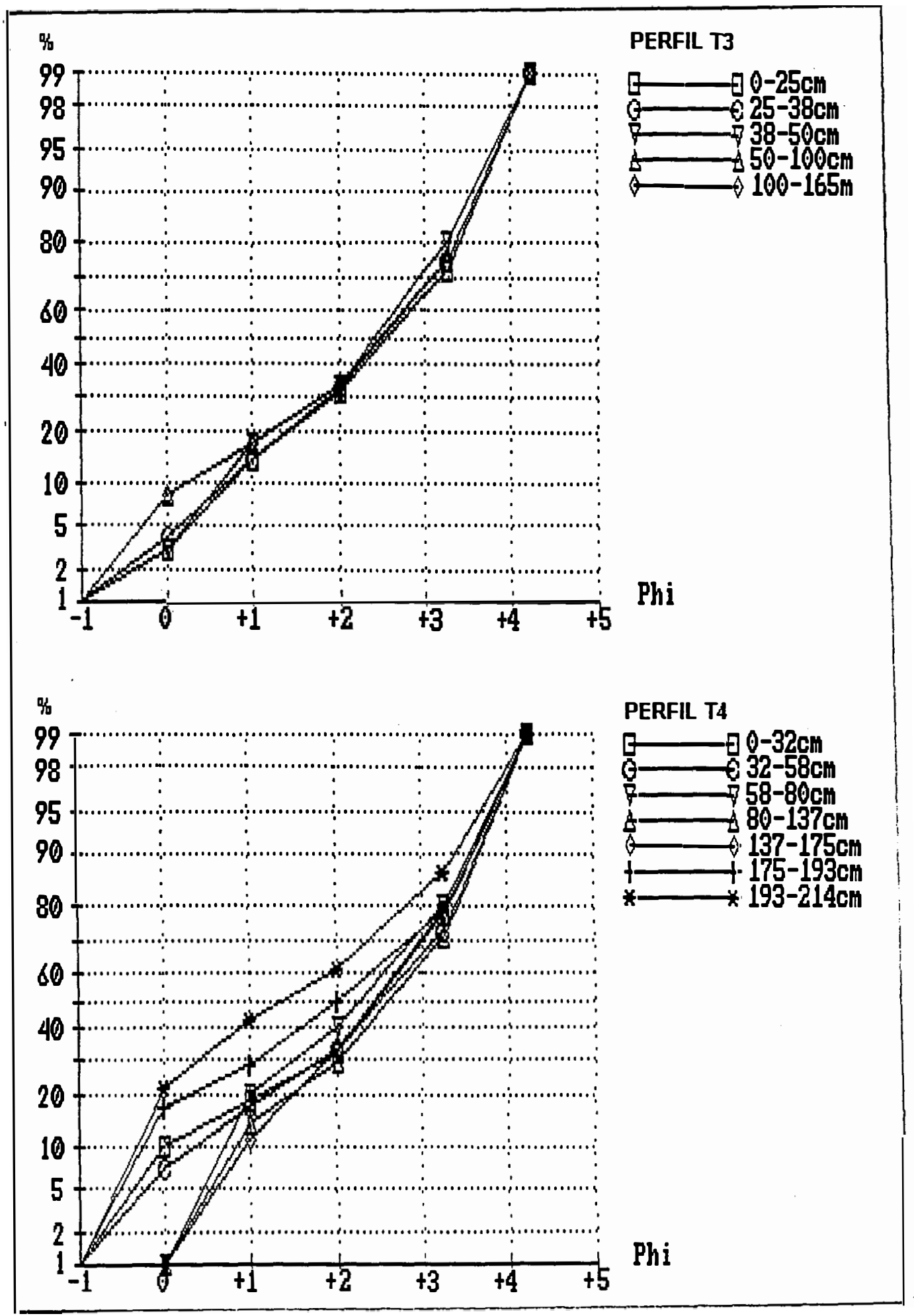

Figura 4.5. Continuação. 
do que pelos deposicionais. Tais resultados se semelham aos obtidos por Jimenez-Rueda \& Demattê. (1988), Gamble et al. (1970) e Cabrera-Martínez et al. (1989) em solos com gradientes texturais acentuado. Divergem entretanto da interpretação dada por Queiroz Neto et al. (1981)., segundo a qual o horizonte E (e EB) dos solos estudados representaria o testemunho de deposição de material arenoso.

A medida que se desloca do T1 para o T4 o teor de argila dos horizontes superficiais tende a decrescer, de $59 \%$ no $\mathrm{T} 1$ para $42 \%$ no $\mathrm{T} 4$, enquanto que cresce o gradiente textural nesta seqüência. As diferenças nos teores de argila de A para o Bt é de $14 \%$ para o $\mathrm{T} 1$ e de $25 \%$ para o $\mathrm{T} 4$. De outro lado, e devido a natureza do material originário, com grande contribuição de argilito e calcário, os teores de argila dos horizontes C, para todos os perfis, é elevado, regra geral na faixa entre 50 e $79 \%$ de argila.

$\mathrm{O}$ fracionamento de argila revelou um aumento de argila fina $(0.2 \mu \mathrm{m}) \mathrm{em}$ profundidade, apresentando valor máximo no $\mathrm{Bt}$ (Tabela 4.3). $\mathrm{O}$ aumento de argila fina em profundidade, ou da relação argila fina / argila total, indica a ocorrência de processos de translocação vertical de argila ao longo do perfil (Soil Survey Staff, 1962, 1975; Floate, 1966); o que é confirmado morfologicamente pela presença de cerosidade nos horizontes iluviais em todos os perfis estudados. Entretanto, o incremento da argila fina nos horizontes $\mathrm{Bt}$, indicado pela relação argila fina/argila total não é grande, principalmente para os perfis T2, T3 e T4. No caso do T2 a relação no horizonte EB é de 0.54 e passa para 0.61 no $\mathrm{Bt}$, decrescendo para 0.57 no $(\mathrm{BCg}) 1$; no $\mathrm{T} 3$ passa de 0.51 no horizonte E para 0.57 no Bt e no T4 de 0,44 no E para 0.54 no Bt. Tais resultados indicam portanto, que outros processos além da lessivagem devem ter contribuído para a gênese destes solos.

\subsection{Propriedades químicas}

Os dados referentes as propriedades químicas (Tabela 4.4) também refletem a influência do material de origem e dos processos genéticos. Os valores da CTC a pH 7,0 normalmente estão acima dos $10 \mathrm{cmo}_{\mathrm{c}} \cdot \mathrm{Kg}^{-1} \mathrm{e}$ atinge valores de 20 ou até 


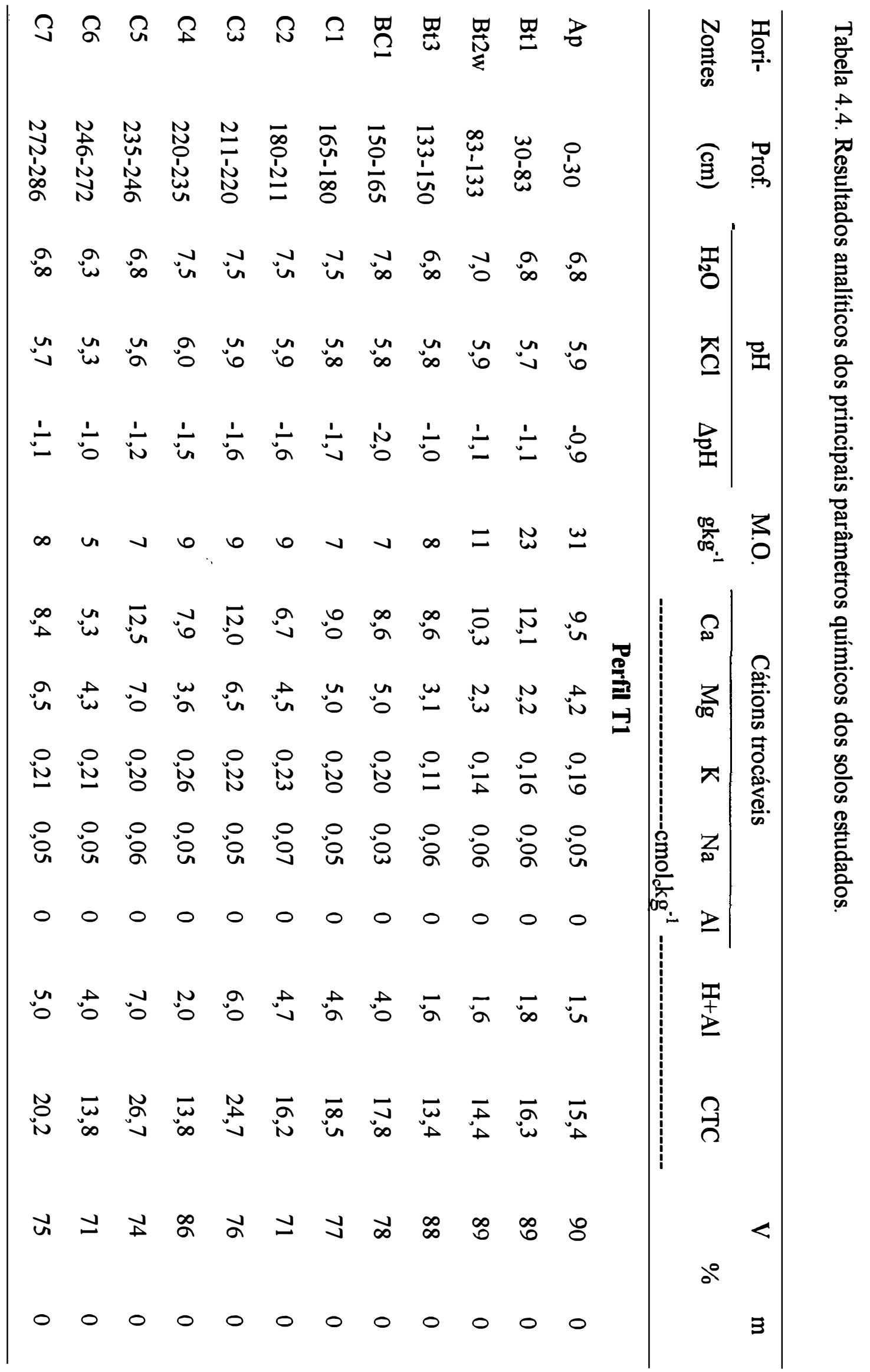




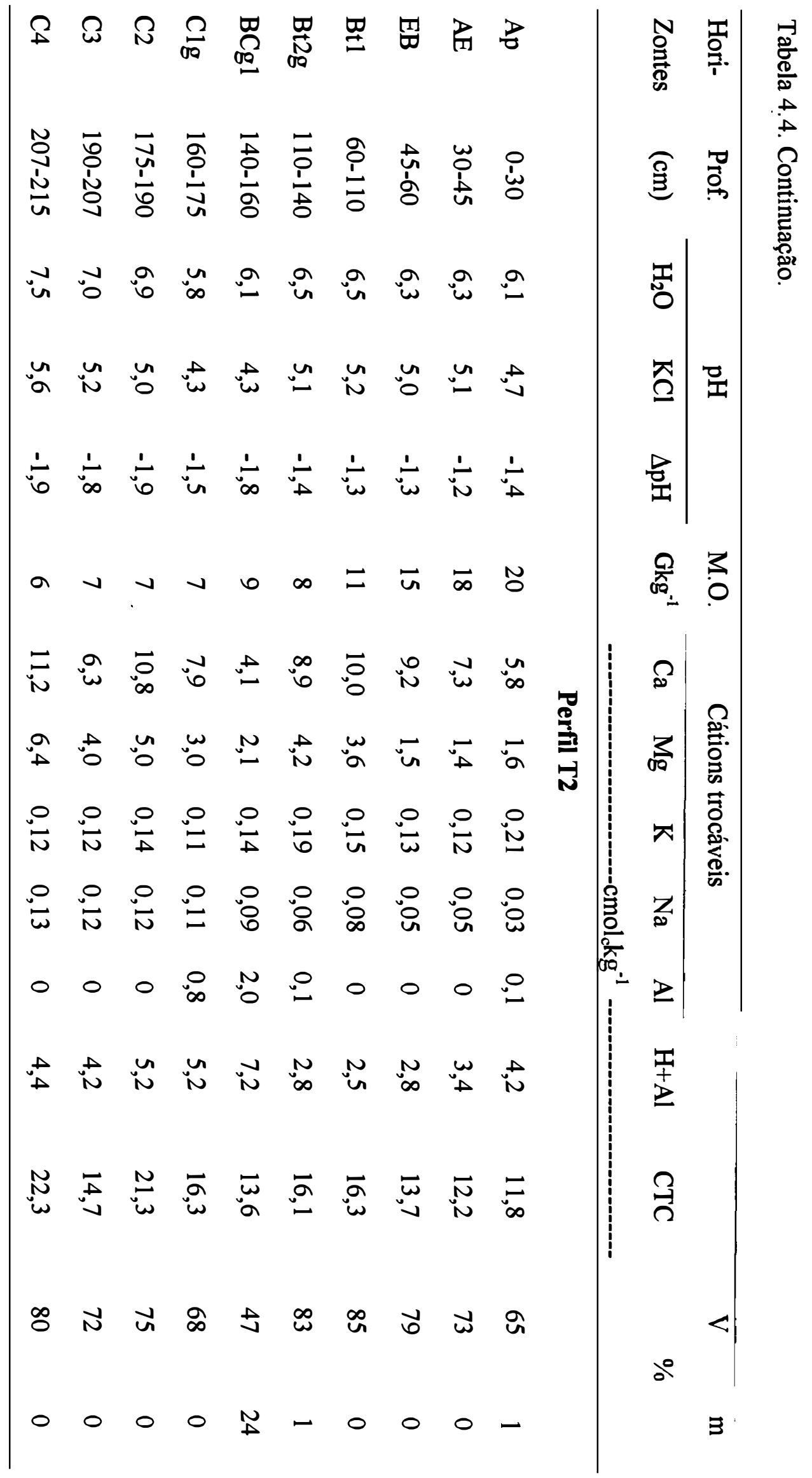




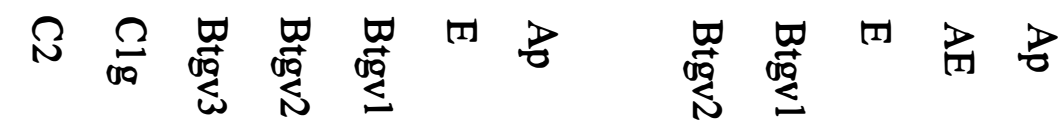

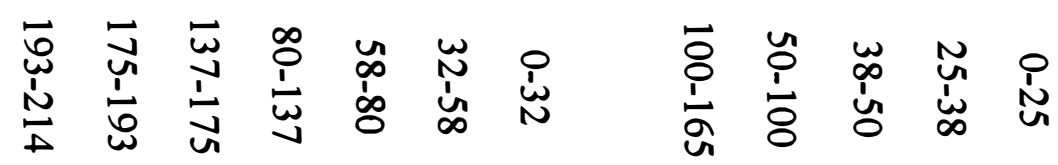

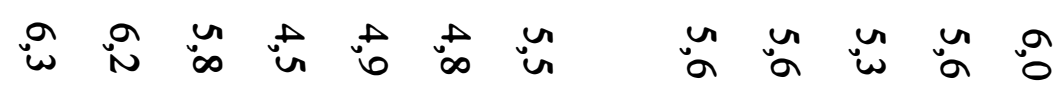

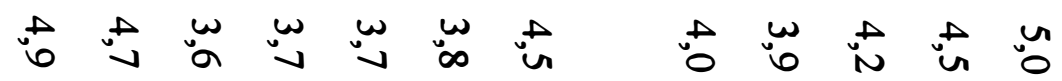

$\therefore$ 虫 N

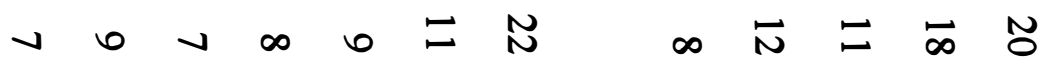

№

$\frac{\overrightarrow{0}}{\stackrel{2}{0}}$

(2)

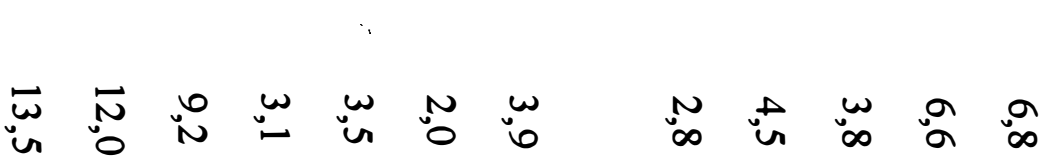

$\infty{ }_{0}^{\infty}$ 虫

:유

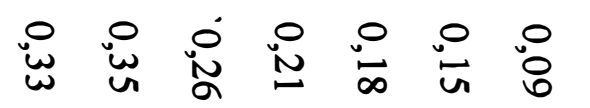

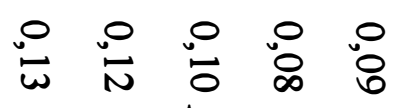

00 n in in 5ू

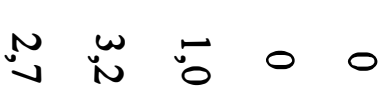

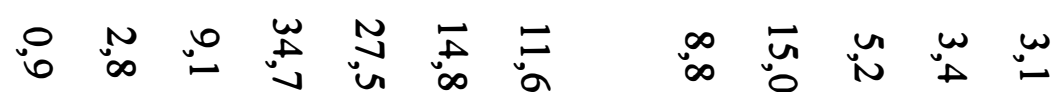

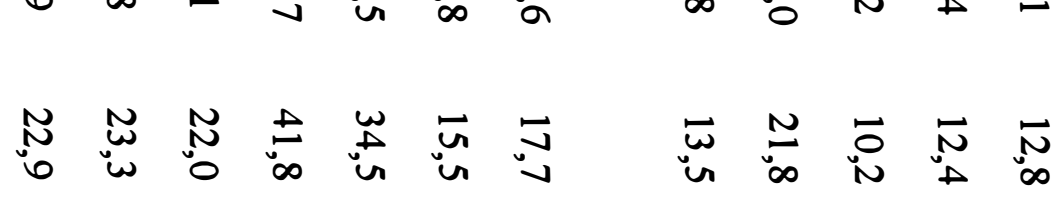

空 茥

点

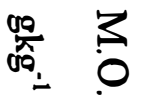

ح|

Z

๑ $\infty$ Uึ

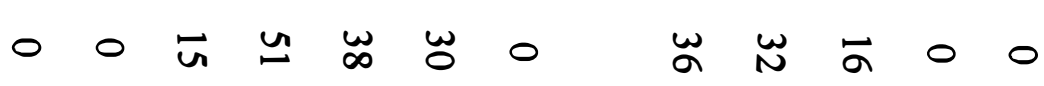


41,8 cmol $_{\mathrm{c}} \cdot \mathrm{kg}^{-1}$ no Btgv2 do T4 inclusive com valores elevados nos horizontes $\mathrm{C}$, como é o caso dos perfis 1 e 4 . $O$ teor da matéria orgânica decresce em profundidade com teores máximo no Ap do $\mathrm{Tl}$ como 31 e $23 \mathrm{~g}^{\mathrm{kg}} \mathrm{kg}^{-1}$ no Btl e mantendo-se na faixa de $20 \mathrm{~g} \mathrm{~kg}^{-1}$ nos horizontes superficiais dos demais perfis. Como o teor de matéria orgânica tende a decrescer em profundidade, tais valores não se correlacionam com a CTC que na maioria dos casos aumenta nos horizontes Bt ou nas camadas de alteração.

No caso específico do perfil T1 a CTC decresce de $15,4 \mathrm{cmol}_{\mathrm{c}} \cdot \mathrm{kg}-1$ no Ap para $14,4 \mathrm{cmol}_{\mathrm{c} . \mathrm{kg}^{-1}}$ no Bt2-w para aumentar a seguir atingindo valores de 24,7 e até 26,7 cmolc.kg-1 nas camadas C3 e C5 respectivamente. Tal resultado decrescente para este perfil em particular, reflete a ação da matéria orgânica pelo menos até a posição do Bt. A partir daí há aumento da CTC e decréscimo de matéria orgânica evidenciando a influência do material de origem e consequentemente da mineralogia. A medida que se dirige do T2 para o T4 nota-se que os valores da CTC acompanham os processos genéticos, no caso da formação dos horizontes de transição $\mathrm{AE}, \mathrm{EB}$ e do $\mathrm{E}$, este nos perfis T3 e T4. Neste caso os valores da CTC decrescem do Ap até o E e, a partir dai aumenta sensivelmente nos horizontes Bt para decrescer a seguir porém mantendo-se valores elevados, normalmente acima de $10 \mathrm{cmol}_{\mathrm{c} . \mathrm{kg}^{-1}}$.

Os valores mais elevados da CTC são encontrados no horizonte $\mathrm{Bt}$ do perfil T4, com 34,5 e 41,8 $\mathrm{cmol}_{\mathrm{c}} \cdot \mathrm{kg}^{-1}$ respectivamente para o Btgvl e Btgv2. Comparando-se os perfis extremos, 1 e 4 no que se refere a CTC nota-se o seguinte:

(a) Os valores da CTC do horizonte superficial dos 2 perfis são de 17,7 e 15,4 cmolc.kg- $^{-}$ ${ }^{1}$ respectivamente para o $\mathrm{T} 4 \mathrm{e} \mathrm{T} 1$ apesar da matéria orgânica e da argila serem mais elevados no $\mathrm{T} 1$.

(b) Os valores da CTC do horizonte $\mathrm{E}$, de máxima perda do $\mathrm{T} 4$ com $41 \%$ de argila e de 11 g. $\mathrm{kg}^{-1}$ de matéria orgânica é praticamente o mesmo do horizonte subsuperficial Btl do $\mathrm{T} 1$ com $73 \%$ de argila e 23 g.kg-1 de matéria orgânica, indicando ser a mineralogia da fração argila do T4 mais ativa do que a do T1.

Esta mineralogia da fração argila mais ativa é ilustrado pelos valores do Ki (Tabela 4.5). No caso do $\mathrm{T} l$ tais valores estão na faixa de 2,0 e 2,13 para os horizontes superfi- 
Tabela 4.5. Resultados do índice Ki dos solos estudados.

\begin{tabular}{|c|c|c|c|c|}
\hline \multirow[t]{2}{*}{ Horizontes } & \multirow{2}{*}{$\begin{array}{l}\text { Prof. } \\
(\mathrm{cm})\end{array}$} & \multicolumn{2}{|c|}{ Ataque sulfúrico (\%) } & \multirow{2}{*}{$\begin{array}{c}\text { İndice } \\
\mathbf{K i}\end{array}$} \\
\hline & & $\mathrm{SiO}_{2}$ & $\mathrm{Al}_{2} \mathrm{O}_{3}$ & \\
\hline \multicolumn{5}{|c|}{ Perfil T1 } \\
\hline Ap & $0-30$ & 9,1 & 7,7 & 2,02 \\
\hline Btl & $30-83$ & 18,9 & 15,2 & 2,12 \\
\hline Bt2-w & 83-133 & 19,2 & 15,3 & 2,13 \\
\hline $\mathrm{Bt} 3$ & $133-150$ & 23,4 & 14,9 & 2,67 \\
\hline$(\mathrm{BC}) 1$ & $150-165$ & 21 , & 13,0 & 2,80 \\
\hline $\mathrm{Cl}$ & $165-180$ & 23,9 & 14,6 & 2,79 \\
\hline $\mathrm{C} 2$ & $180-211$ & 17,4 & 11,2 & 2,65 \\
\hline $\mathrm{C} 3$ & $211-220$ & 25,0 & 13,8 & 3,09 \\
\hline $\mathrm{C} 4$ & $220-235$ & 19,9 & 11,7 & 2,93 \\
\hline C5 & $235-246$ & 30,2 & 14,6 & 3,56 \\
\hline C6 & $246-272$ & 21,4 & 12,1 & 3,05 \\
\hline $\mathrm{C7}$ & $272-286$ & 22,2 & 12,2 & 3,10 \\
\hline \multicolumn{5}{|c|}{ Perfil T2 } \\
\hline Ap & $0-30$ & 6,2 & 4,8 & 2,18 \\
\hline $\mathrm{AE}$ & $30-45$ & 6,5 & 4,6 & 2,41 \\
\hline EB & $45-60$ & 8,8 & 6,4 & 2,33 \\
\hline Btl & $60-110$ & 24,4 & 15,6 & 2,70 \\
\hline Bt2g & $110-140$ & 21,7 & 12,8 & 2,88 \\
\hline$(\mathrm{BCg}) 1$ & $140-160$ & 20,7 & 13,8 & 2,55 \\
\hline $\mathrm{Clg}$ & $160-175$ & 22,5 & 13,6 & 2,82 \\
\hline $\mathrm{C} 2$ & $175-190$ & 15,4 & 9,5 & 2,76 \\
\hline $\mathrm{C} 3$ & $190-207$ & 17,1 & 10,7 & 2,71 \\
\hline $\mathrm{C} 4$ & $207-215$ & 10,8 & 12,8 & 2,63 \\
\hline
\end{tabular}


Tabela 4.5. Continuação.

\begin{tabular}{lcccc}
\hline Horizontes & $\begin{array}{c}\text { Prof. } \\
\text { (cm) }\end{array}$ & \multicolumn{2}{c}{ Ataque sulfúrico (\%) } & Índice \\
\cline { 3 - 4 } & & $\mathrm{SiO}_{2}$ & $\mathrm{Al}_{2} \mathrm{O}_{3}$ & $\mathrm{Ki}$ \\
\hline Ap & $0-25$ & 6,2 & 4,6 & 2,3 \\
$\mathrm{AE}$ & $25-38$ & 6,5 & 4,8 & 2,3 \\
E & $38-50$ & 12,2 & 8,7 & 2,4 \\
Btgvl & $50-100$ & 22,4 & 13,3 & 2,9 \\
Btgv2 & $100-165$ & 16,1 & 10,5 & 2,6 \\
& & Perfil T3 & \\
Ap & $0-32$ & 7,5 & 5,0 & 2,6 \\
E & $32-58$ & 7,6 & 5,5 & 2,4 \\
Btgv1 & $58-80$ & 14,3 & 8,5 & 2,9 \\
Btgv2 & $80-137$ & 22,5 & 12,5 & 3,1 \\
Btgv3 & $137-175$ & 21,5 & 12,8 & 2,8 \\
Clg & $175-193$ & 23,8 & 13,3 & 3,1 \\
C2 & $193-214$ & 17,0 & 6,9 & 4,1 \\
\hline
\end{tabular}

ciais Ap e Bt2 enquanto que no T4 os valores vão de 2,4 a 2,6 no horizonte E e Ap respectivamente e de 2,9 a 3,1 nos horizontes Bt. De acordo com as informações contidas em Tolentino de C. (1956); e Camargo et al. (1986), valores de ki entre 2,0 e 2,5 indicam dominância de mineralogia caulinitica com contribuição de minerais 2:1 enquanto que os valores $\mathrm{Ki}$ entre 2,5 e 3,0 indicam dominância de minerais 2:1 com contribuição de caulinita. Valores de Ki na faixa de 0.6 a 1,5 (Cerrados), indicam solos de mineralogia oxídica (Demattê, J.L \& Demattê, J. A., 1993).

Se consideramos o material de origem sendo homogêneo ao longo da seqüência T1 a T4 como mostram os dados morfológicos e os granulométricos, nas 
relações já discutidas, a influência do alagamento, que aumenta do T1 para o T4, contribui para uma maior relação $\mathrm{Si} / \mathrm{Al}$ neste sentido dando condições para uma evolução mineralógica mais ativa como já indicado por Brinkman (1970), Lindsay (1979) ; Kittrick (1969); Gerasinova (1981); Vodyanitskii et al. (1997).

A saturação de bases também tende a refletir a influência do material originário e os processos genéticos. Assim é que para o caso do T1 os valores do V\% são extremadamente elevados, entre $90 \%$ no horizonte superficial e $88 \%$ no $\mathrm{Bt} 3$, com sensíveis reflexos no $\mathrm{pH}$ na faixa de 6,8 a 7,5. Tais valores se devem seguramente à ação do calcário. Entretanto, a medida que a ação do encharcamento temporário (principalmente nos horizontes superficiais dos perfis 3 e 4) se manifesta, ocorre redução da saturação das bases, com valores mais baixos no T4 atingindo faixas de 20 e $17 \%$ nos horizontes Bt1 e Bt2 respectivamente deste perfil. A redução na saturação das bases tem um reflexo direto no $\mathrm{pH}$, caindo para 4,9 e 4,5 respectivamente nestes horizontes e aumento no teor de alumínio, com $38 \%$ no horizonte Btl e $51 \%$ no Bt2 (carácter álico). Em relação ao teor de sódio trocável, o elemento mais solúvel no complexo de troca do solo, tende a se concentrar no ambiente de menor drenagem. Assim é que no T1, perfil de boa drenagem o teor deste elemento é neglegível . A medida que se dirige para o T2 já ocorre uma maior concentração a partir do horizonte $\mathrm{Clg}$, a $160 \mathrm{~cm}$ de profundidade. No caso do T4 valores de $0.15 \mathrm{cmol}_{\mathrm{c}} \cdot \mathrm{kg}^{-1}$ já se encontram no horizonte $\mathrm{E}$ a $32 \mathrm{~cm}$ de profundidade. A presença deste sódio indica o seguinte:

(a). Migração lateral de íons em solução em direção ao T4.

(b).Favorece a formação de estruturas maiores e com tendências a colunar no T4 (Birkeland, 1984; Buol et al., 1997).

Em relação ao potássio alguns aspectos devem ser ressaltados a saber:

(a). A acumulação nos horizontes superficiais de todos os perfis estudados, se deve aos efeitos de reciclagem e das adubações; como se sabe freqüentes na cultura de cana.

(b). O próprio material de origem, argilitos e folhelhos são ricos em micas e consequentemente em K (Demattê et al., 1977; Moniz et al., 1995). 
(c) A maior concentração nos perfis de drenagem mais restrita se deve também a migração, em solução, para tais perfis. $O$ teor de óxido de ferro total determinado pelo ataque sulfúrico não é elevado (Tabela 4.6) ficando na faixa dos 8,8 \% para o horizonte (BC) 1 do $\mathrm{T} 1$ a 4,4\% no Ap deste mesmo perfil. Camadas mais inferiores, tais como a $\mathrm{C} 1, \mathrm{C} 3$ apresentam teores mais elevados. Tais valores destas camadas de alteração se devem a influência do próprio material de origem constituído pelas camadas alternadas de argilitos e pela presença da pirita no calcário (Figura 4.19 $\mathrm{V}$, na página 158).

A medida que ocorre a ação do encharcamento nos demais solos o teor de ferro total dos horizontes pedogenéticos tende a decrescer. Note nos horizontes $\mathrm{E}$ dos perfis T3 e T4 que o teor de ferro total é menor do que nos demais horizontes A razão ferro oxalato (Fe-Ox) / ferro ditionito (Fe-DCB) é menor do que 0.1 na maior parte dos horizontes de todos o perfis estudados (Tabela 4.6) indicando o predomínio de formas cristalinas de óxido de ferro, inclusive nos horizontes de máxima perda $(\mathrm{E})$ onde os processos de oxidação e redução são mais freqüentes. Quando a relação $\mathrm{Fe}$ (o) / Fe (d) é menor que 0.1 há presença de goethita, hematita e lepidocrosita (Schwertmann et al., 1982). O teor de Fe- DCB para todos os perfis estudados tende a aumentar em profundidade, e decresce em direção ao T4. Nos horizontes transicionais, como o $\mathrm{AE}$ no T2, E nos perfis T3 e T4, os valores do Fe- DCB são os menores observados.

A quantidade de ferro oxalato (Fe- Ox) que indica ferro amorfo (Schwertmann, 1989) é bem inferior ao Fe-DCB. A tendência nos valores do Fe- Ox nos perfis 2 a 4 é o de decrescer do Ap em direção aos horizontes B onde tornam a aumentar, justamente onde há maior teor de argila, bem como numa redução no sentido T1 ao T4, resultante dos processos de solubilização e remoção deste elemento motivado pelo encharcamento.

Os ciclos alternados de redução e oxidação estão implicados na gênese das alterações das camadas do solo onde promovem a dissolução dos óxidos de ferro favorecendo assim os processos de destruição dos argilominerais pela ferrólise (Brinkman, 1970; Gerasinova, 1981; Jimenez-Rueda \& Demattê, 1988; Demattê et al., 1995; Vodyanitskii et al., 1997). De acordo com os autores citados, o aumento nos teores de 
Tabela 4.6. Ferro total determinado pelo ataque sulfúrico, ferro extraído pelo DCB e ferro extraído pelo oxalato.

\begin{tabular}{|c|c|c|c|c|c|}
\hline \multirow[t]{2}{*}{ Horizonte } & \multirow{2}{*}{$\begin{array}{l}\text { Prof. } \\
\text { (cm) }\end{array}$} & \multicolumn{3}{|c|}{$\mathrm{Fe}(\%)$} & \multirow{2}{*}{$\begin{array}{c}\text { Relação } \\
\mathrm{Fe}(\mathrm{o}) / \mathrm{Fe}(\mathrm{d})\end{array}$} \\
\hline & & Total & $\mathrm{DCB}(\mathrm{d})$ & Ox(o) & \\
\hline \multicolumn{6}{|c|}{ Perfil T1 } \\
\hline Ap & $0-30$ & 4,4 & 3,8 & 0,60 & 0,16 \\
\hline Bt1 & $30-83$ & 5,3 & 4,6 & 0,69 & 0,15 \\
\hline Bt2-w & $83-133$ & 5,6 & 4,9 & 0,49 & 0,10 \\
\hline Bt3 & $133-150$ & 7,6 & 6,6 & 0,80 & 0,12 \\
\hline (BC)1 & $150-165$ & 8,8 & 7,9 & 0,63 & 0,08 \\
\hline $\mathrm{Cl}$ & $165-180$ & 13,7 & 11,2 & 0,34 & 0,03 \\
\hline $\mathrm{C} 2$ & $180-211$ & 9,5 & 7,6 & 0,23 & 0,03 \\
\hline $\mathrm{C} 3$ & $211-220$ & 17,5 & 14,3 & 1,57 & 0,11 \\
\hline $\mathrm{C} 4$ & $220-235$ & 9,5 & 5,7 & 0,56 & 0,09 \\
\hline C5 & $235-246$ & 16,9 & 13,1 & 1,04 & 0,08 \\
\hline C6 & $246-272$ & 10,5 & 8,4 & 0,42 & 0,05 \\
\hline C7 & $272-286$ & 12,5 & 9,8 & 0,68 & 0,07 \\
\hline \multicolumn{6}{|c|}{ Perfil T2 } \\
\hline Ap & $0-30$ & 3,1 & 2,8 & 0,33 & 0,12 \\
\hline $\mathrm{AE}$ & $30-45$ & 1,6 & 1,4 & 0,18 & 0,13 \\
\hline EB & $45-60$ & 2,6 & 2,3 & 0,23 & 0,09 \\
\hline Btl & $60-110$ & 4,5 & 4,1 & 0,32 & 0,08 \\
\hline $\mathrm{Bt} 2 \mathrm{~g}$ & $110-140$ & 2,9 & 2,1 & 0,30 & 0,14 \\
\hline BCg1 & $140-160$ & 4,2 & 3,6 & 0,26 & 0,06 \\
\hline $\mathrm{Clg}$ & $160-175$ & 11,2 & 8,2 & 0,73 & 0,08 \\
\hline $\mathrm{C} 2$ & $175-190$ & 5,2 & 4,2 & 0,29 & 0,06 \\
\hline $\mathrm{C} 3$ & $190-207$ & 4,5 & 3,2 & 0,25 & 0,07 \\
\hline C4 & $207-215$ & 11,8 & 10,0 & 0,50 & 0,05 \\
\hline \multicolumn{6}{|c|}{ Perfil T3 } \\
\hline Ap & $0-25$ & 2,9 & 2,6 & 0,42 & 0,16 \\
\hline $\mathrm{AE}$ & $25-38$ & 3,2 & 2,9 & 0,37 & 0,13 \\
\hline E & $38-50$ & 1,3 & 1,1 & 0,11 & 0,10 \\
\hline Btgvl & $50-100$ & 2,7 & 2,3 & 0,18 & 0,08 \\
\hline Btgv2 & $100-165$ & 4,1 & 3,7 & 0,22 & 0,05 \\
\hline
\end{tabular}


Tabela 4.6. Continuação.

\begin{tabular}{lccccc}
\hline Horizonte & $\begin{array}{c}\text { Prof. } \\
(\mathrm{cm})\end{array}$ & Total & DCB(d) & Ox(o) & $\begin{array}{c}\text { Relação } \\
\text { Fe(o)/Fe(d) }\end{array}$ \\
\cline { 3 - 5 } & & \multicolumn{3}{c}{ Perfil T4 } \\
Ap & $0-32$ & 2,3 & 2,1 & 0,32 & 0,15 \\
E & $32-58$ & 1,4 & 1,1 & 0,06 & 0,05 \\
Btgv1 & $58-80$ & 3,2 & 2,9 & 0,34 & 0,11 \\
Btgv2 & $80-137$ & 3,4 & 3,1 & 0,31 & 0,10 \\
Btgv3 & $137-175$ & 3,1 & 2,7 & 0,19 & 0,07 \\
Clg & $175-193$ & 9,5 & 6,7 & 0,33 & 0,04 \\
C2 & $193-214$ & 2,9 & 2,0 & 0,10 & 0,05 \\
\hline
\end{tabular}

$\mathrm{Fe}^{2+}$ motivado pela redução no solo, induz maior lixiviação dos demais cátions, devido à presença do ferro no complexo de troca. Nestas reações e principalmente na transformação $\mathrm{Fe}^{2+}$ para $\mathrm{Fe}^{3+}$ (oxidação), há aumento na concentração de íons $\mathrm{H}^{+}$que pode induzir a protólise das lâminas octaedrais e tetraedrais tornando os argilominerais instáveis e possíveis de se inteemperizarem. Parte do alumínio liberado nestas reações pode ser intercalado nas camadas de vermiculita, na forma de polímero e parte fica na solução do solo (Almeida et al., 1997). O solo tende a ficar mais ácido e com maior teor de $\mathrm{Al}$ em solução, como aliás se verifica no perfil T4. Grande parte do silício do T4 permanece concentrado na parte de menor drenagem da seqüência devido ao enriquecimento vertical ou lateral.

Devido ao baixo teor de Fe-DCB encontrado nos perfis, principalmente no T4 (Tabela 4.6) é pouco provável que o enriquecimento em sílica se dê unicamente as expensas da remoção do ferro mas sim por destruição parcial ou total de argila, favorecida pelos processos de oxi-redução.

Nos horizonte AE e E dos perfis T3 e T4 as características de intensa alteração química induzida pelo encharcamento, indicam que esta última hipótese seja mais provável. Levando-e em consideração a correlação entre a cor do solo e natureza dos óxidos de ferro constatado por inúmeros autores (Resende, 1976; Karmanova, 1981; Duchaufour, 
1982; Schwertmann et al., 1982; Torrent et al., 1983; Kämp \& Schwertmann, 1983; Sokolov, 1997; Buol et al., 1997), salienta-se que no caso do T1, nos horizontes Bt a predominância de cores avermelhadas (matiz 2,5YR 3/4 e 3/6), indica dominância de hematita. De outro lado a medida que se dirige do $\mathrm{T} 1$ ao $\mathrm{T} 4$ as cores do solo passam para o matiz 5YR, 7,5YR e 10YR este no perfil T4 indicando com isso dominância de goethita. $\mathrm{O}$ amarelecimento do solo principalmente nos horizontes $\mathrm{Ap}$ e $\mathrm{AE}$, e na porção superior do Bt no T4 pode ser atribuído à goethita (Almeida et al., 1997).

De acordo com tais autores a hipótese mais plausivel é de que esse amarelecimento se deva a um processo de dissolução de hematita em profundidade, pelo efeito da saturação temporária no horizontes transicionais. Esta dissolução dos óxidos de ferro é favorecida pela saturação temporária de água, nos horizontes transicionais e pela disponibilidade de fontes de energia pela ação dos microorganismos advinda do transporte de carbono solúvel dos horizontes superficiais.

$\mathrm{Na}$ tabela 4.7. se apresenta os resultados das análises do enxofre $\mathrm{S}_{-} \mathrm{SO}_{4}$, e dos micronutrientes $\mathrm{Cu}, \mathrm{Fe}, \mathrm{Mn}, \mathrm{Zn}$ e o elemento $\mathrm{Na}$. Nos primeiros $150 \mathrm{~cm}$ de profundidade do $\mathrm{T} 1$, os valores do enxofre estão na faixa de 6 a $9,1 \mathrm{mg}^{-\mathrm{dm}^{-3}}$ do Ap até o $\mathrm{Bt} 2$, aumentando no $\mathrm{Cl}$ e o no (BC) 1 com 106 e $113,1 \mathrm{mg}^{-\mathrm{dm}^{-3}}$ respectivamente.

Nos horizontes inferiores os valores se alternam entre valores altos e baixos, sendo influenciado pela presença de material pirobetuminoso das camadas de folhelhos, próprio dos materiais da FI. As rachaduras e os canais devida à bioturbação propiciam- 
Tabela 4.7. Análise química do $\mathrm{P}$, enxofre, micronutrientes e o elemento $\mathrm{Na}$

\begin{tabular}{|c|c|c|c|c|c|c|c|c|c|}
\hline \multirow[t]{2}{*}{ Horiz. } & Prof. & $\mathrm{P}$ & $\mathrm{S}_{-\mathrm{SO}_{4}}$ & B & $\mathrm{Cu}$ & $\mathrm{Fe}$ & Mn & $\mathrm{Zn}$ & $\mathrm{Na}$ \\
\hline & (cm) & \multicolumn{8}{|c|}{$\mathrm{mg} / \mathrm{dm}^{3}$} \\
\hline \multicolumn{10}{|c|}{ Perfil T1 } \\
\hline Ap & $0-30$ & 54 & 6,0 & 0,4 & 3,8 & 12,0 & 110,3 & 90,0 & 11,5 \\
\hline Btl & $30-83$ & 9 & 9,1 & 0,4 & 3,2 & 10,0 & 97,8 & 24,6 & 11,5 \\
\hline Bt2-w & $83-133$ & 9 & 9,1 & 0,4 & 1,6 & 6,0 & 53,2 & 13,8 & 20,7 \\
\hline $\mathrm{Bt} 3$ & $133-150$ & 12 & 7,0 & 0,3 & 1,0 & 5,0 & 19,9 & 4,7 & 13,8 \\
\hline $\mathrm{BCl}$ & $150-165$ & 7 & 113,1 & 0,5 & 0,6 & 3,3 & 9,8 & 1,2 & 9,2 \\
\hline $\mathrm{Cl}$ & $165-180$ & 10 & 106,0 & 0,4 & 0,4 & 5,5 & 27,5 & 1,9 & 11,5 \\
\hline $\mathrm{C} 2$ & $180-211$ & 4 & 25,5 & 0,4 & 0,6 & 3,1 & 16,2 & 5,0 & 11,5 \\
\hline $\mathrm{C} 3$ & $211-220$ & 20 & 113,1 & 0,3 & 0,3 & 15,2 & 65,0 & 5,3 & 9,2 \\
\hline C4 & $220-235$ & 4 & 24,1 & 0,4 & 0,4 & 3,2 & 16,5 & 11,5 & 13,8 \\
\hline C5 & $235-246$ & 17 & 113,1 & 0,3 & 0,3 & 14,3 & 54,4 & 0,7 & 11,5 \\
\hline C6 & $246-272$ & 4 & 14,9 & 0,4 & 0,7 & 5,3 & 18,5 & 1,3 & 13,8 \\
\hline C7 & $272-286$ & 11 & 29,8 & 0,4 & 0,5 & 13,5 & 57,4 & 2,6 & 16,1 \\
\hline \multicolumn{10}{|c|}{ Perfil T2 } \\
\hline Ap & $0-30$ & 7 & 10,0 & 0,5 & 3,8 & 83 & 281,0 & 8,9 & 9,2 \\
\hline $\mathrm{AE}$ & $30-45$ & 3 & 7,5 & 0,4 & 3,9 & 84 & 240,0 & 8,7 & 13,8 \\
\hline EB & $45-60$ & 2 & 3,6 & 0,3 & 4,2 & 62 & 104,8 & 16,8 & 16,1 \\
\hline Btl & $60-110$ & 2 & 3,6 & 0,4 & 2,2 & 19 & 11,4 & 9,4 & 18,4 \\
\hline Bt2g & $110-140$ & 2 & 21,2 & 0,1 & 1,0 & 19 & 15,3 & 0,8 & 18,4 \\
\hline BCgl & $140-160$ & 2 & 24,5 & 0,1 & 0,7 & 2 & 26,2 & 1,1 & 18,4 \\
\hline $\mathrm{Clg}$ & $160-175$ & 3 & 39,6 & 0,1 & 0,7 & 6 & 121,0 & 1,5 & 23,0 \\
\hline $\mathrm{C} 2$ & $175-190$ & 2 & 24,9 & 0,1 & 1,3 & 46 & 70,4 & 23,0 & 34,5 \\
\hline C3 & $190-207$ & 4 & 29,0 & 0,1 & 1,4 & 41 & 57,8 & 9,7 & 41,4 \\
\hline C4 & $207-215$ & 9 & 55,3 & 0,1 & 0,6 & 45 & 97,6 & 3,4 & 34,5 \\
\hline \multicolumn{10}{|c|}{ Perfil T3 } \\
\hline Ap & $0-25$ & 13 & 7,8 & 0,3 & 2,7 & 97 & 161 & 4,1 & 20,7 \\
\hline $\mathrm{AE}$ & $25-38$ & 6 & 10,9 & 0,2 & 2,6 & 93 & 94 & 1,4 & 18,4 \\
\hline E & $38-50$ & 8 & 13,7 & 0,3 & 3,2 & 98 & 11,5 & 1,4 & 34,5 \\
\hline Btgvl & $50-100$ & 3 & 28,8 & 0,3 & 1,3 & 40 & 3,5 & 0,9 & 43,7 \\
\hline Btgv2 & $100-165$ & 4 & 44,7 & 0,4 & 1,0 & 16 & 11,6 & 2,4 & 34,5 \\
\hline \multicolumn{10}{|c|}{ Perfil T4 } \\
\hline Ap & $0-32$ & 14 & 24,8 & 0,5 & 2,5 & 140 & 136,2 & 5,3 & 23,0 \\
\hline E & $32-58$ & 5 & 18,5 & 0,5 & 2,8 & 94 & 5,3 & 1,9 & 39,1 \\
\hline Btgvl & $58-80$ & 4 & 11,1 & 0,3 & 1,7 & 77 & 2,9 & 0,7 & 55,2 \\
\hline Btgv2 & $80-137$ & 2 & 21,5 & 0,3 & 0,2 & 22 & 1,5 & 0,1 & 66,7 \\
\hline Btgv3 & $137-175$ & 4 & 19,7 & 0,2 & 1,1 & 39 & 29,8 & 0,7 & 69,0 \\
\hline $\mathrm{Clg}$ & $175-193$ & 11 & 7,5 & 0,1 & 0,6 & 40 & 229,0 & 0,3 & 78,2 \\
\hline $\mathrm{C} 2$ & $193-214$ & 3 & 2,6 & 0,1 & 1,8 & 10 & 16,7 & 0,8 & 75,9 \\
\hline
\end{tabular}


condições aeróbicas neste perfil de boa drenagem, e o enxofre é convertido em $\mathrm{SO}_{4}{ }^{-}$. Em condições anaeróbicas no caso dos horizontes T3 e T4, o sulfato pode ser reduzido pelos microorganismos em $\mathrm{SO}_{3}{ }^{2-}$ (Tan, 1996 p. 183).

Quanto ao boro, seu valores em geral são baixos e quase constante nos perfis, na faixa de 0.1 a $0.5 \mathrm{~g} \cdot \mathrm{dm}^{-3}$.

A concentração do $\mathbf{C u}$ é baixa, ligeiramente maior nos horizontes superficiais, variando na faixa de 3,2 a $3,8 \mathrm{mg}^{-\mathrm{dm}^{-3}}$ no Btl e Ap do perfil T1 respectivamente, mantendo o mesmo valor do Ap no T2, para logo diminuir de 2,7 a 2,5 mg. $\mathrm{dm}^{-3}$ nos horizontes Ap dos perfis T3 e T4. Esta tendência se deve ao fato dos ions cuprosos serem instáveis em soluções aquosas e, afetados automaticamente por processos de oxi-redução (Tan, 1996).

O Fe nos horizontes Ap de boa drenagem, aumenta de $12 \mathrm{mg} \cdot \mathrm{dm}^{-3}$ no T1 para 83 no T2, 97 no T3 até $140 \mathrm{mg}$. $\mathrm{dm}^{-3}$ no Ap do T4 drenagem restrita. Observe-se no perfil T4 que o Fe diminui de $140 \mathrm{mg}$. $\mathrm{dm}^{-3}$ no Ap até 10 no horizonte $\mathrm{C} 2$, zona de máxima oscilação do lençol freático. Este comportamento do Fe é uma evidência de que em condições gleizadas o $\mathrm{Fe}$ é móvel e na presença de $\mathrm{S}_{-} \mathrm{SO}_{4}$ o $\mathrm{Fe}$ pode formar compostos cristalinos como a pirita (Chestworth, 1991). A pirita foi encontrada nestes solo e nas camadas plano-paralelas do material geológico na zona de estudo.

O Mn, é um elemento que se encontra em maior quantidade em relação aos demais micronutrientes, com maior concentração nos horizontes superficiais mas apresentando tendências de aumento e redução ao longo do perfil. No caso do T1 o teor do Ap é $110,3 \mathrm{mg} \cdot \mathrm{dm}^{-3}$. A maior concentração do Mn é notada no AE e no Ap do perfil $\mathrm{T} 2$ com 240 e $281 \mathrm{mg} \cdot \mathrm{dm}^{-3}$. No $\mathrm{T} 3$ e no $\mathrm{T} 4$ os valores diminuem em profundidade, exceto no $\mathrm{Clg}$ do $\mathrm{T} 4$ que atinge valores de $229 \mathrm{mg}^{-\mathrm{dm}^{-3}}$, mesmo assim no $\mathrm{Clg}$ do $\mathrm{T} 2$ atinge valor elevado $\left(121 \mathrm{mg} \cdot \mathrm{dm}^{-3}\right)$.

Quanto ao Zn mostra uma relativa acumulação nos horizontes superficiais diminuindo ligeiramente com a profundidade, atingindo um valor no T1 de $90 \mathrm{mg} \cdot \mathrm{dm}^{-3}$ no Ap e um mínimo de 0.1 no Btgv2 do perfil T4. Isso pode indicar que o $\mathrm{Zn}$ é alterado pelas condições de redução (Chesworth, 1991, p.26). O elemento Na tem 
um papel importante na geoquímica dos micronutrientes e sua dissolução é atribuída à hidrólise da albita. A distribuição dos microelementos e o elemento $\mathrm{Na}$ é visualizada na Figura 4.6.

\subsection{Espectrografia de Raios- $X$}

A utilização de espectrografia de Raios- $X$ tem diversas finalidades no estudo da gênese de solos entre elas as seguintes: (a) permite um estudo completo dos diversos componentes dos minerais e nas diversas frações do solo; (b) possibilita a determinação de elementos traços e elementos mais estáveis importantes para estudos de homogeneidade de material e de ganhos e perdas.

Os dados aqui apresentados, resumidos nas Tabelas 4.8 e 4.9, indicam os teores, em óxidos, de $\mathrm{Na}, \mathrm{Mg}, \mathrm{Al}, \mathrm{Si}, \mathrm{P}, \mathrm{K}, \mathrm{Ca}$, Ti e $\mathrm{Fe}$; tanto para a fração areia como para o solo total. 

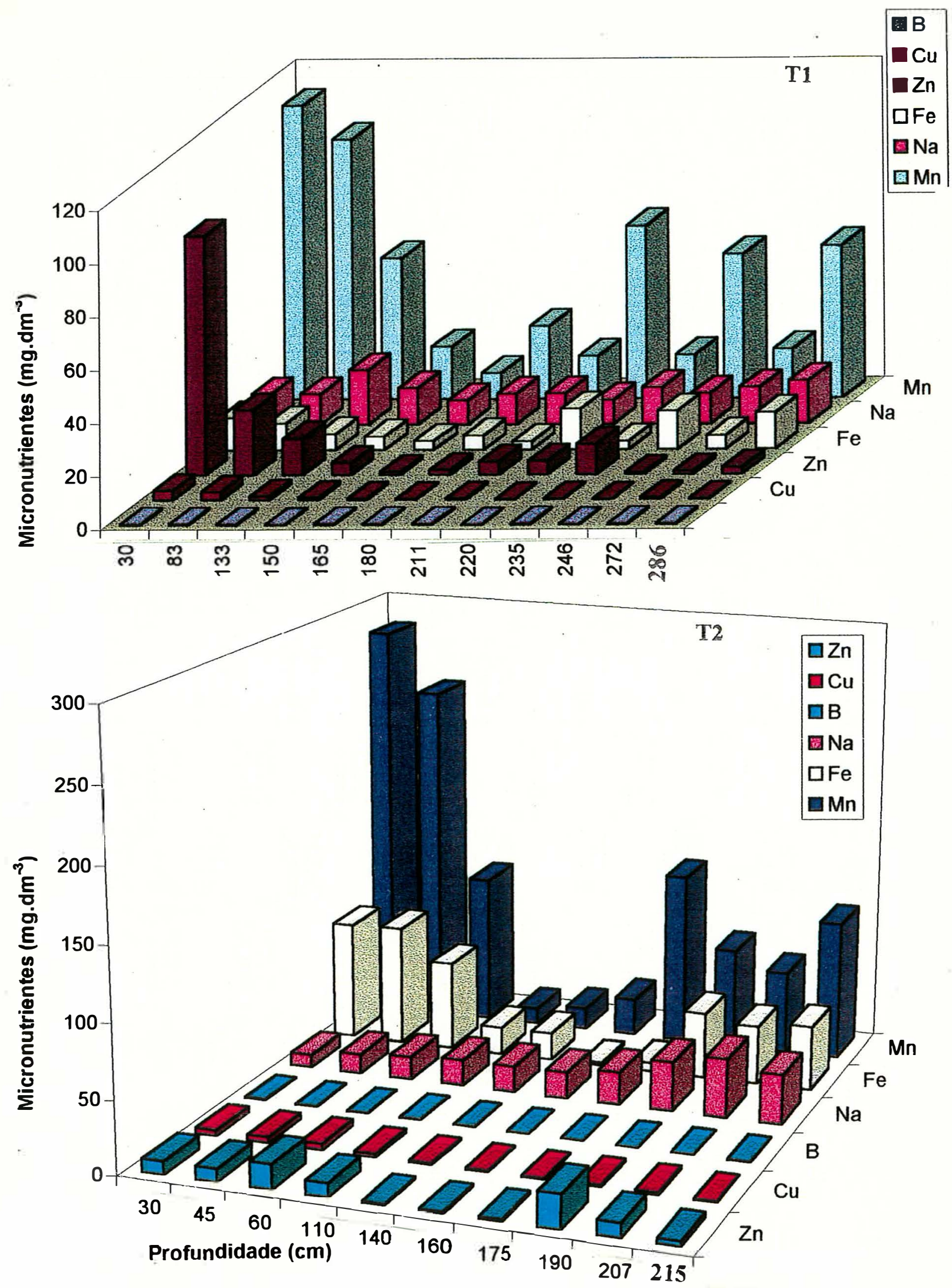

Figura 4.6. Distribuição dos micronutrientes e o elemento Na nos perfis. 

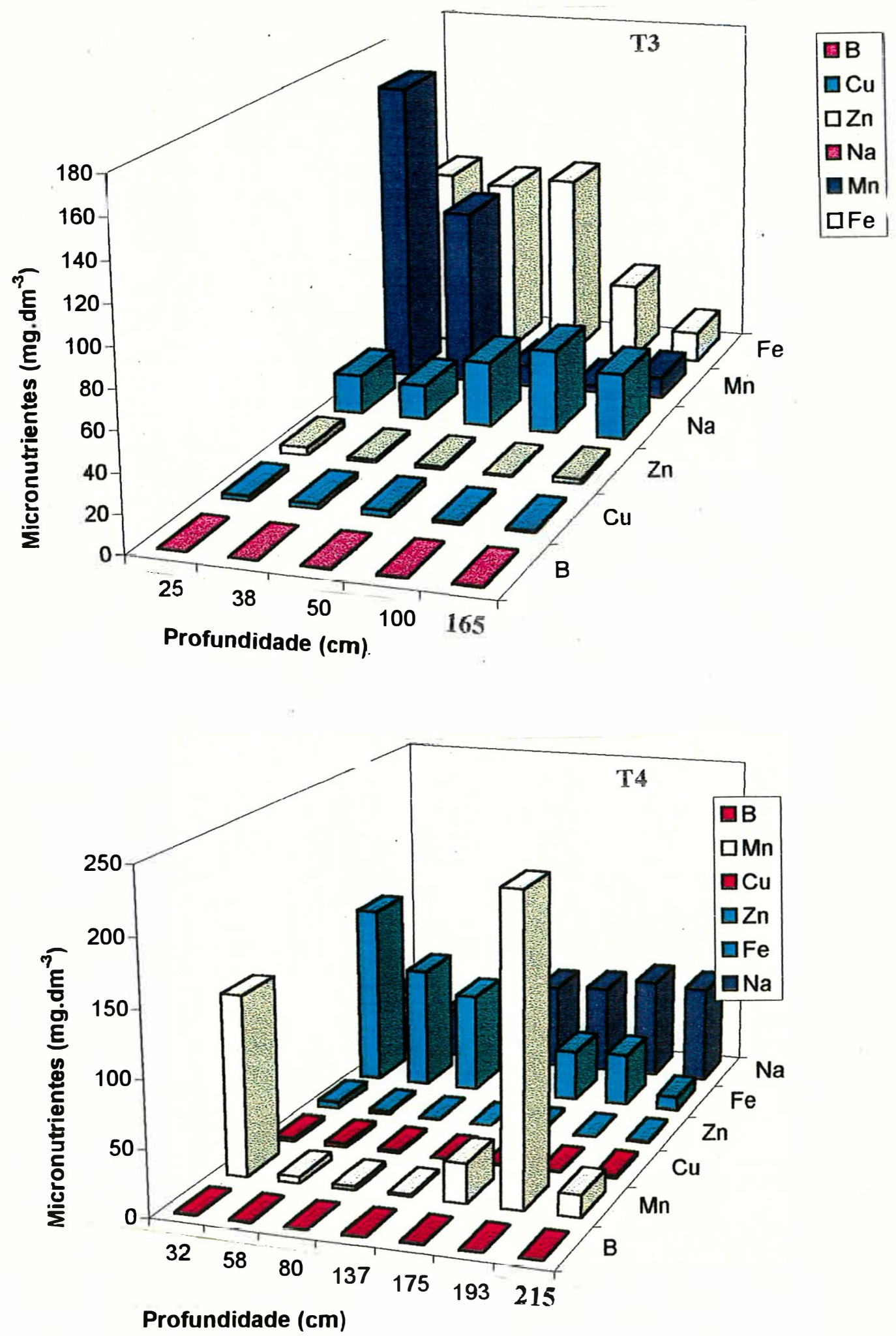

Figura 4.6. Continuação. 
Para o estudo de homogeneidade de material de origem e cálculos de ganhos e perdas diversos autores entre eles Brewer (1964); Demattê, (1978); Wilding et al. (1983); Demattê et al. (1991), se utilizam de elementos mais estáveis ou relações entre tais elementos. No caso específico deste trabalho foi utilizado o titânio como elemento mais estável. De acordo com Sherman \& Kaneshiro (1965), o titânio ocorre menos de $1 \%$ na crosta terrestre, mas em zonas tropicais é maior que $1 \%$ devido a acumulação dos óxidos.

Levando-se em consideração os resultados da fração areia (Tabela 4,8), observa-se baixos teores de Ti porém constantes em profundidade e teores semelhantes entre os perfis. A maior estabilidade deste elemento nos ambientes aqui estudados pode ser observado quando se compara com os demais elementos. Levando-se em consideração que os horizontes mais agredidos pelo intemperismo são os de transição e o $\mathrm{E}$, dos perfis T3 e T4, mesmo assim os teores de Ti não se alteram enquanto houve alteração nos demais elementos.

Por outro lado quando se observa os teores de Ti no solo total, eles tendem a decrescer ligeiramente em profundidade porém de uma forma muito homogênea, não havendo nenhuma quebra na seqüência. Tal fato se deve ao caracter mais arenoso dos horizontes superficiais onde se concentra mais titânio quando comparado com os horizontes subsuperficiais .

Além disso o teor deste elemento no solo é ligeiramente maior do que na fração areia. Isto se deve ao fato deste elemento poder estar presente também nas frações mais finas, como o silte (Wilding et al., 1983). Tais resultados vem confirmar que o material de origem dos perfis aqui estudados é homogêneo.

Camadas mais ricas em Mn podem ser observadas ao longo dos perfis $\mathrm{T} 1, \mathrm{~T} 2$ e $\mathrm{T} 4$. No caso do $\mathrm{T} 1$ há camadas de concentração deste elemento na 


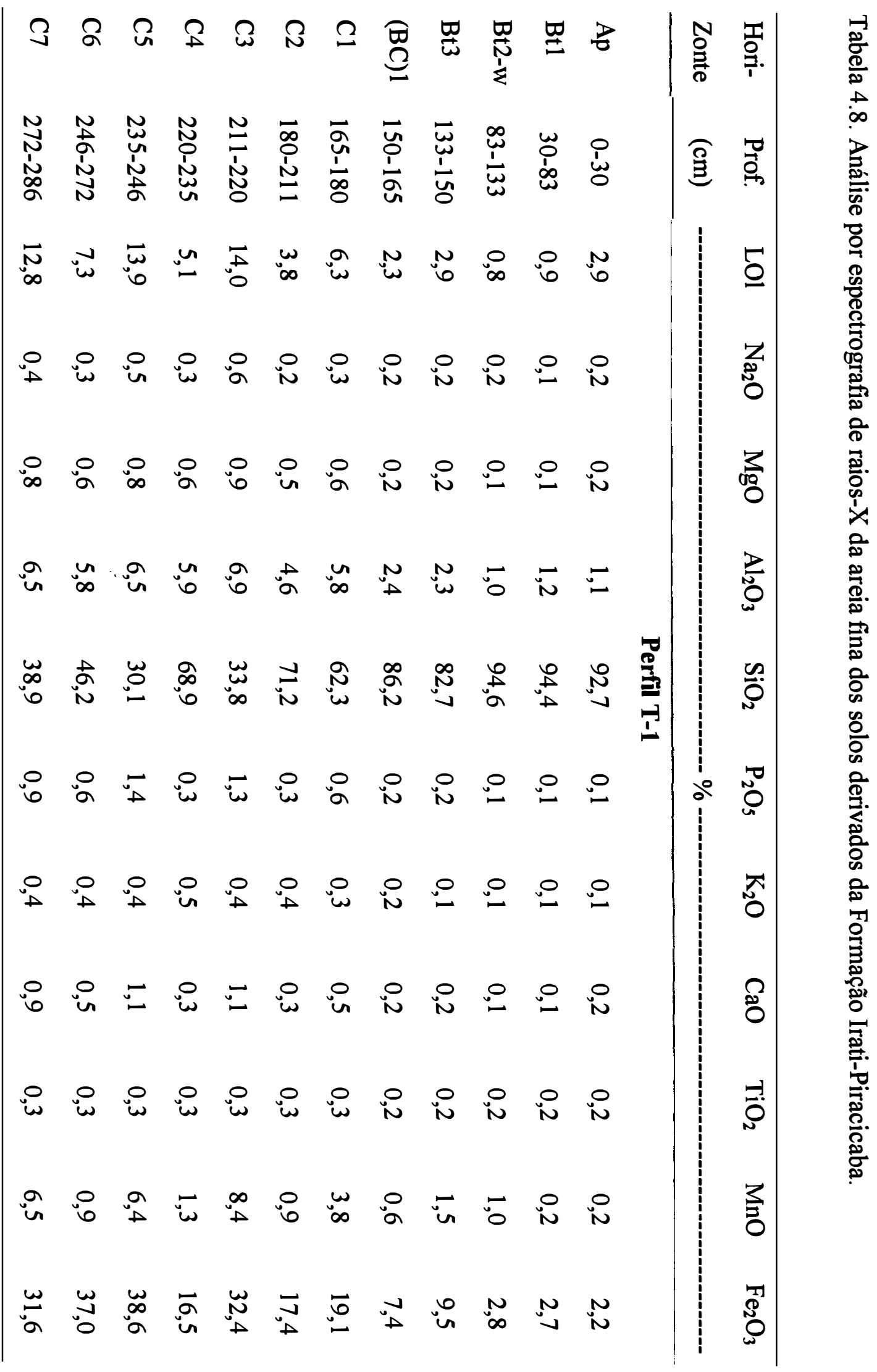




\begin{tabular}{|c|c|c|c|c|c|c|c|c|c|c|c|c|}
\hline$\AA$ & $\widetilde{\omega}$ & N & 2 & $\underbrace{\stackrel{\mathscr{P}}{0}}_{\mathscr{0}}$ & $\underset{\sim 0}{\mathbb{N}}$ & $\stackrel{\mathscr{W}}{\underline{\Xi}}$ & $\mathbb{W}$ & $\mathbb{n}_{\mathrm{n}}$ & D & & 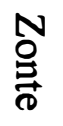 & 공 \\
\hline $\begin{array}{l}\text { O } \\
\stackrel{+}{N} \\
\stackrel{\sim}{U}\end{array}$ & $\begin{array}{l}\overline{8} \\
\text { ㅇ } \\
\text { ஸे }\end{array}$ & $\frac{\bar{v}}{\frac{1}{0}}$ & $\begin{array}{l}\vec{g} \\
\frac{1}{u} \\
\vec{v}\end{array}$ & $\begin{array}{l}\overrightarrow{0} \\
\frac{1}{2} \\
\end{array}$ & $\frac{\overline{\vec{D}}}{\frac{1}{\Delta}}$ & $\begin{array}{l}\stackrel{9}{0} \\
\stackrel{1}{0}\end{array}$ & $\begin{array}{l}\hat{n} \\
\grave{g}\end{array}$ & $\begin{array}{l}w \\
0 \\
\dot{b} \\
\dot{\omega}\end{array}$ & $\stackrel{P}{\dot{\omega}}$ & & $\overparen{\mathfrak{g}}$ & $\underset{0}{\overrightarrow{0}}$ \\
\hline $\bar{\omega}_{\Delta}^{\omega}$ & 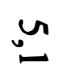 & un & w & w & $\bar{\omega}$ & ن & ○ & $\stackrel{\infty}{\infty}$ & 战 & & & 5 \\
\hline ن & 足 & 足 & $\stackrel{\infty}{\infty}$ & $\stackrel{0}{\omega}$ & N & 只 & No & 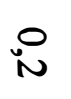 & $\stackrel{\circ}{N}$ & & & Z゙ \\
\hline 5 & ○ & 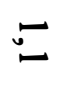 & $\underset{\infty}{\infty}$ & 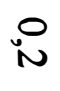 & $\circ$ & ○ & ○0 & ○ & $\because$ & & & 3 \\
\hline$\stackrel{\infty}{N}$ & in & w & जू & w & $\overline{\mathrm{in}}$ & 5 & 5 & 5 & in & & & D \\
\hline$\underset{\perp}{\infty}$ & $\underset{0}{N}$ & i & 㟧 & $\stackrel{\infty}{\infty}$ & $\begin{array}{l}\text { N } \\
\text { an }\end{array}$ & $\underset{\omega}{\stackrel{\phi}{\omega}}$ & u v & 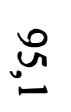 & $\begin{array}{l}\text { N } \\
\text { Na }\end{array}$ & $\stackrel{0}{3}$ & & مึ \\
\hline مै & O & 次 & ○ & 只 & $\stackrel{0}{-1}$ & $\stackrel{0}{ }$ & $\stackrel{0}{\circ}$ & $\stackrel{0}{-0}$ & $\stackrel{0}{0}$ & & de & ָָ \\
\hline in & in & ○。 & 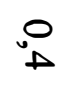 & $\stackrel{O}{N}$ & $\stackrel{\circ}{N}$ & $\circ$ & $\circ$ & $\stackrel{0}{0}$ & N & & & 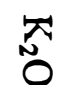 \\
\hline مٌ & N & N & in & 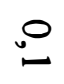 & $\because$ & $\circ$ & $\stackrel{\circ}{ }$ & $\stackrel{0}{0}$ & $\stackrel{0}{0}$ & & & مి \\
\hline ơ & o & $\overbrace{\triangle}^{\circ}$ & 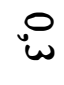 & $\stackrel{O}{N}$ & O̊ & 只 & $\stackrel{0}{N}$ & $\stackrel{0}{N}$ & O & & & $\overrightarrow{0}$ \\
\hline$\stackrel{\infty}{N}$ & 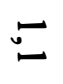 & $\stackrel{0}{\circ}$ & م0 & ○ & $\stackrel{0}{-1}$ & $\stackrel{0}{-0}$ & $\stackrel{\circ}{\circ}$ & $\stackrel{\circ}{N}$ & $\stackrel{0}{\circ}$ & & & 3 \\
\hline$\omega$ & $\bar{I}$ & $\bar{\omega}$ & No & 三 & $\omega$ & $\omega$ & 0 & $N$ & $\omega$ & & & $\pi$ \\
\hline N & 0 & $\infty$ & $\stackrel{\Delta}{+}$ & - & $v$ & $\checkmark$ & w"w & N & & & & 0 \\
\hline
\end{tabular}




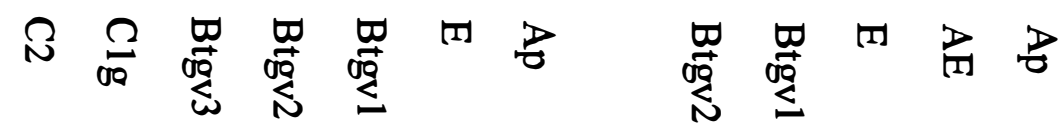

№

궁.

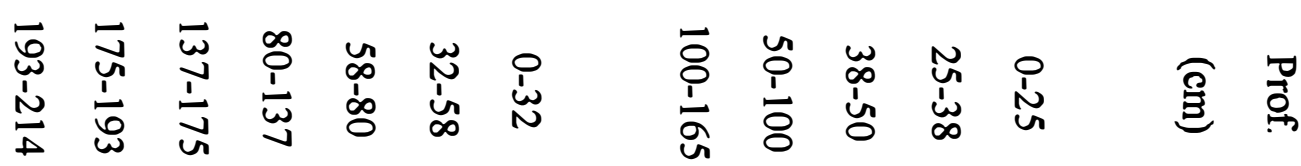

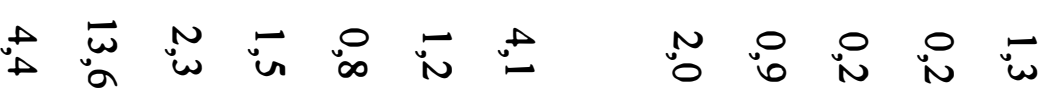

뭉
0
0

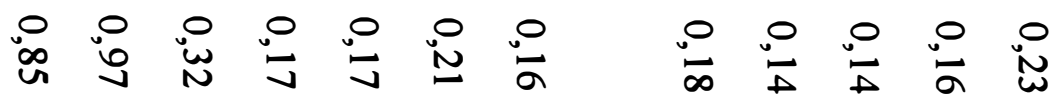

茫

3

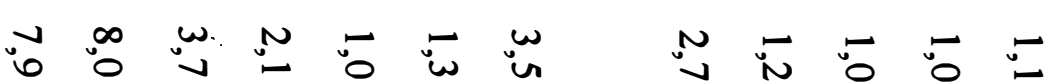

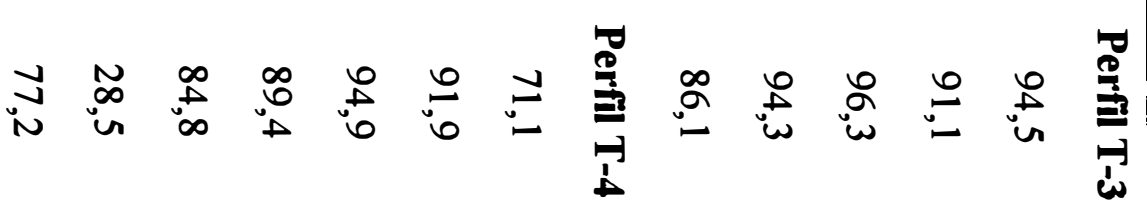

嵒

范怘

జัญ

.

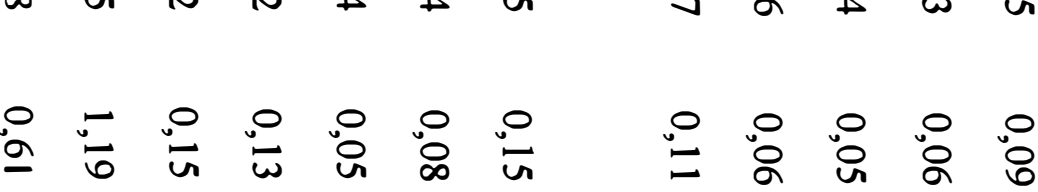

○

일

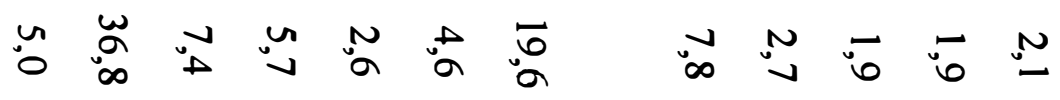

ڤี

จำ

3

@ొ 


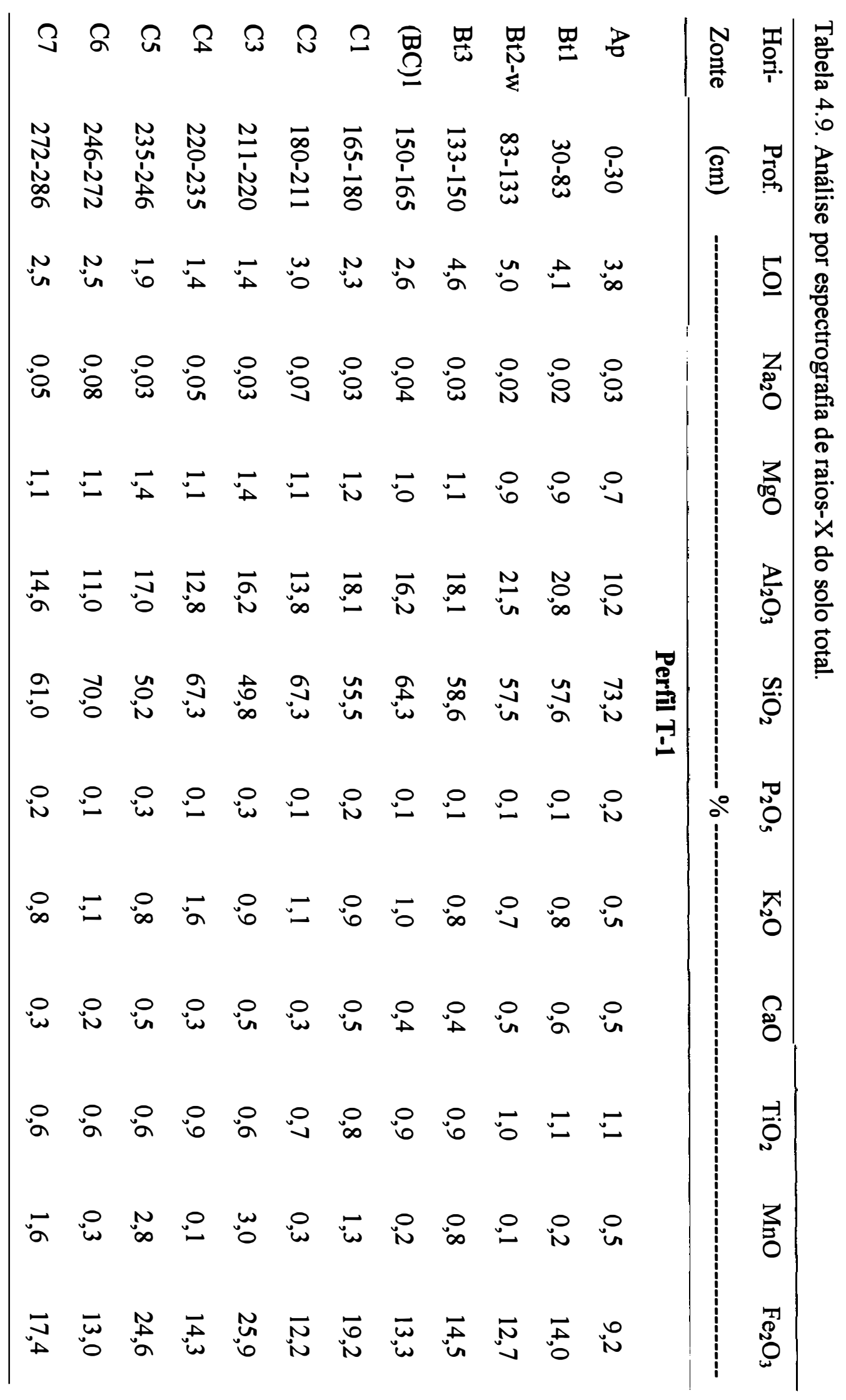


预

\begin{tabular}{|c|c|c|c|c|c|c|c|c|c|c|c|c|}
\hline$\Omega$ & $\widehat{\omega}$ & N & $\Omega_{00}$ & 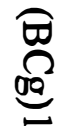 & $\underset{\infty}{\mathbb{N}}$ & $\stackrel{\mathscr{I}}{=}$ & $\underset{\omega}{\pi}$ & 尚 & $\frac{D}{D}$ & & $\begin{array}{l}\text { N } \\
\stackrel{0}{*}\end{array}$ & 产 \\
\hline $\begin{array}{l}\text { O } \\
\stackrel{N}{N} \\
\stackrel{N}{\sim}\end{array}$ & $\begin{array}{l}\text { б̊ } \\
\stackrel{1}{0} \\
\text { ஸे }\end{array}$ & $\frac{\vec{v}}{\frac{1}{0}}$ & $\begin{array}{l}\bar{g} \\
\dot{1} \\
\dot{v}\end{array}$ & $\begin{array}{l}\vec{B} \\
\frac{1}{8} \\
\frac{1}{8}\end{array}$ & $\begin{array}{l}\overrightarrow{0} \\
\frac{\dot{1}}{0}\end{array}$ & $\frac{9}{\stackrel{1}{0}}$ & $\begin{array}{l}\text { ث) } \\
\grave{1} \\
\text { 。 }\end{array}$ & $\begin{array}{l}\stackrel{w}{o} \\
\dot{1} \\
\stackrel{1}{u}\end{array}$ & 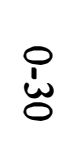 & & $\stackrel{\Im}{\Xi}$ & $\overrightarrow{0}$ \\
\hline & w & $\underset{v}{w}$ & $\underset{\Delta}{\sim}$ & $\underset{\omega}{\omega}$ & $\stackrel{+}{N}$ & ò & $\underset{0}{+\infty}$ & טه & w & & & $\stackrel{5}{0}$ \\
\hline $\begin{array}{l}\circ \\
\stackrel{0}{1}\end{array}$ & $\begin{array}{l}0 \\
0 \\
0\end{array}$ & $\begin{array}{l}0 \\
0 \\
0\end{array}$ & $\begin{array}{l}0 \\
0 \\
\circ\end{array}$ & \begin{tabular}{l}
0 \\
0 \\
0 \\
\hdashline
\end{tabular} & ○ & $\begin{array}{l}\circ \\
\text { 옹 }\end{array}$ & $\begin{array}{l}0 \\
\text { No }\end{array}$ & $\begin{array}{l}0 \\
0 \\
0\end{array}$ & $\begin{array}{l}0 \\
\text { 옹 }\end{array}$ & & & జై \\
\hline in & 岀 & w & N & "w & ñ & 5 & $\stackrel{0}{\circ}$ & ${ }_{1}^{0}$ & $\stackrel{0}{\circ}$ & & & $\frac{3}{00}$ \\
\hline $\bar{u}$ & $\bar{\omega}_{\Delta}$ & $\stackrel{N}{\Delta}$ & 芯 & $\vec{a}$ & $\vec{D}$ & $\begin{array}{l}\text { No } \\
\stackrel{D}{*}\end{array}$ & م0 & in & N & & & 莕 \\
\hline$\underset{\infty}{\infty}$ & à & $\stackrel{\infty}{\infty}$ & $\underset{\infty}{\mathscr{D}}$ & 岀 & ù & $\stackrel{\infty}{\infty}$ & ๙̃ & $\begin{array}{l}\text { ఎ } \\
\text { a }\end{array}$ & $\stackrel{\infty}{\circ}$ & $\stackrel{0}{3}$ & & $\stackrel{n}{0}$ \\
\hline No & $\stackrel{0}{-0}$ & $\because$ & $\because$ & 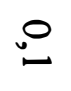 & $\stackrel{0}{-}$ & $\because$ & $\stackrel{0}{-}$ & $\stackrel{0}{\square}$ & $\therefore$ & & di & م్ర \\
\hline 5 & 5 & $5^{-}$ & $\begin{array}{l}0 \\
\infty \\
\infty\end{array}$ & 。 & ○o & $\stackrel{\infty}{\infty}$ & in & $\stackrel{0}{\circ}$ & $\underset{D}{0}$ & & & 좀 \\
\hline o & No & No & o & o & 足 & in & 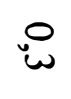 & No & No & & & ̊ి \\
\hline $\begin{array}{l}0 \\
\text { a } \\
\text { an }\end{array}$ & $\stackrel{0}{v}$ & $\stackrel{0}{v}$ & in & $\stackrel{0}{N}$ & ○ & - & $=$ & 5 & 5 & & & تجم \\
\hline & in & O & $\stackrel{ \pm}{ \pm}$ & $\stackrel{0}{1}$ & $\stackrel{0}{0}$ & $\stackrel{0}{-}$ & O & 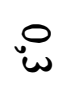 & 怘 & & & 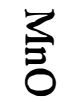 \\
\hline & ప & E & $\stackrel{N}{\sigma}$ & $\overline{0}$ & $\begin{array}{l}0 \\
a\end{array}$ & $\overline{0}$ & $\stackrel{\infty}{-\infty}$ & $\underset{D}{\top}$ & N & & & فై \\
\hline
\end{tabular}




\begin{tabular}{|c|c|c|c|c|c|c|c|c|c|c|c|c|c|c|c|}
\hline N & $\underset{\infty}{\Omega}$ & 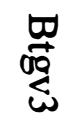 & 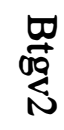 & 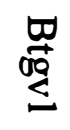 & $(\pi)$ & b & & 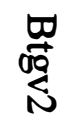 & 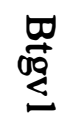 & $(\pi)$ & 尚 & $\frac{D}{D}$ & & $\begin{array}{l}\text { No } \\
\stackrel{\overbrace{}}{\overparen{D}}\end{array}$ & 禎 \\
\hline $\begin{array}{l}\overrightarrow{0} \\
\stackrel{\omega}{\sim} \\
\vec{\Delta}\end{array}$ & $\frac{\vec{v}}{\underline{u}}$ & $\begin{array}{l}\vec{w} \\
\dot{v} \\
\vec{v}\end{array}$ & $\begin{array}{l}\stackrel{\infty}{0} \\
\stackrel{1}{\omega}\end{array}$ & $\begin{array}{l}n \\
\infty \\
1 \\
\infty \\
0\end{array}$ & $\underset{\infty}{\omega}$ & 寍 & & $\begin{array}{l}\overrightarrow{8} \\
\stackrel{1}{\mathbf{n}} \\
\text { n }\end{array}$ & $\begin{array}{l}\text { ñ } \\
\frac{1}{8}\end{array}$ & $\begin{array}{l}\omega \\
\infty \\
\dot{d}\end{array}$ & $\begin{array}{l}\text { N } \\
\dot{\infty}\end{array}$ & 虽 & & $\stackrel{\overbrace{}}{3}$ & 营 \\
\hline & & w & w & $\sqrt[5]{ }$ & $\stackrel{N}{\infty}$ & $\begin{array}{l}\omega \\
\infty\end{array}$ & & un & $\stackrel{+}{0}$ & 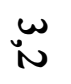 & w & $\stackrel{\Delta}{N}$ & & & $\stackrel{5}{0}$ \\
\hline 怘 & $\begin{array}{l}0 \\
\circ \\
0\end{array}$ & $\begin{array}{l}\circ \\
\circ \\
\circ\end{array}$ & $\begin{array}{l}\circ \\
\circ \\
\circ\end{array}$ & $\begin{array}{l}\circ \\
\text { ○̊ } \\
\text { W̊ }\end{array}$ & $\begin{array}{l}0 \\
0 \\
10\end{array}$ & $\begin{array}{l}0 \\
\stackrel{0}{0} \\
\stackrel{9}{1}\end{array}$ & & 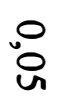 & 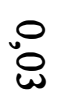 & $\begin{array}{l}0 \\
\text { No } \\
\text { No }\end{array}$ & $\begin{array}{l}0 \\
\text { ○ }\end{array}$ & 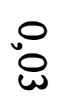 & & & $\begin{array}{l}Z \\
\text { जै } \\
0\end{array}$ \\
\hline$\stackrel{N}{N}$ & $\varpi_{\infty}$ & 5 & $\underset{\sim}{\sigma}$ & مै & ○ & in & & $\bar{n}$ & ○ & $\begin{array}{l}\circ \\
\text { ○ }\end{array}$ & 唄 & $\stackrel{0}{+}$ & & & 3 \\
\hline$\underset{\infty}{\circ}$ & $\underset{\infty}{\vec{a}}$ & un & $\underset{N}{\vec{A}}$ & 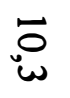 & N & $\stackrel{9}{ }$ & & $\vec{\Delta}$ & $\underset{\infty}{\vec{\infty}}$ & $\stackrel{\omega}{\omega}$ & $\stackrel{v}{v}$ & י人 & & & D. \\
\hline un & 哭 & $\underset{0}{N}$ & $\stackrel{8}{+}$ & $\underset{\infty}{O}$ & $\stackrel{\infty}{v}$ & $\underset{\perp}{\infty}$ & $\begin{array}{l}\stackrel{0}{3} \\
\stackrel{9}{9} \\
\overrightarrow{8}\end{array}$ & $\begin{array}{l}\text { ○े } \\
0\end{array}$ & $\stackrel{\text { जे }}{\sim}$ & $\underset{\Delta}{\omega}$ & $\begin{array}{l}\infty \\
0 \\
0\end{array}$ & $\stackrel{\infty}{\infty}$ & 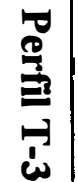 & & "ִ \\
\hline $\begin{array}{l}\circ \\
\infty \\
\infty\end{array}$ & $\stackrel{0}{D}$ & $\begin{array}{l}\circ \\
\circ \\
\$ \\
\perp\end{array}$ & $\begin{array}{l}\circ \\
\text { 용 }\end{array}$ & $\begin{array}{l}0 \\
\stackrel{0}{0} \\
\stackrel{9}{0}\end{array}$ & $\begin{array}{l}0 \\
0 \\
0\end{array}$ & $\stackrel{0}{\infty}$ & & ○ & $\stackrel{0}{D}$ & $\begin{array}{l}0 \\
\text { un }\end{array}$ & $\stackrel{0}{\omega}$ & $\frac{0}{\text { un }}$ & & $\begin{array}{l}1 \\
\text { å } \\
1\end{array}$ & סִ \\
\hline " & 。o & 5 & $\stackrel{\infty}{\circ}$ & $\stackrel{\circ}{\sim}$ & $\stackrel{\circ}{v}$ & $\stackrel{0}{v}$ & & ○0 & $\stackrel{\infty}{\infty}$ & $\begin{array}{l}0 \\
0 \\
0\end{array}$ & $\begin{array}{l}0 \\
\perp\end{array}$ & $\sim_{\perp}^{0}$ & & & $\underset{0}{\pi}$ \\
\hline $\begin{array}{l}0 \\
\infty \\
0 \\
0\end{array}$ & $\stackrel{0}{\infty}$ & $\stackrel{\infty}{N}^{\circ}$ & $\stackrel{\circ}{N}$ & $\begin{array}{l}0 \\
0 \\
0 \\
0\end{array}$ & $\frac{0}{0}$ & $\underset{0}{0}$ & & ○ & ○̊ & 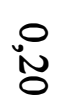 & $\stackrel{0}{N}$ & 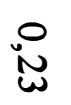 & & & مُ \\
\hline in & in & 。 & $\stackrel{\infty}{\circ}$ & 5 & 虫 & $\vec{N}$ & & 5 & 5 & 5 & 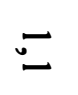 & 5 & & & تُ \\
\hline $\begin{array}{l}\circ \\
\stackrel{0}{\circ}\end{array}$ & $\begin{array}{l}\omega \\
\text { sి }\end{array}$ & $\begin{array}{l}0 \\
0 \\
0\end{array}$ & 只 & ○ & $\begin{array}{l}0 \\
\text { N } \\
0\end{array}$ & $\begin{array}{l}0 \\
0 \\
0\end{array}$ & & $\begin{array}{l}0 \\
0 \\
0\end{array}$ & 옹 & $\begin{array}{l}\text { O } \\
\text { "o }\end{array}$ & $\stackrel{\infty}{\infty}$ & $\stackrel{0}{N}$ & & & 疍 \\
\hline${ }^{u}$ & $\stackrel{N}{\omega}$ & $u_{\infty}^{n}$ & $\because n$ & un & un & $\therefore$ & & \begin{tabular}{l}
$\infty$ \\
\hdashline$a$
\end{tabular} & $\begin{array}{l}0 \\
\infty\end{array}$ & in & ñ & $\stackrel{9}{0}$ & & & $\begin{array}{l}\text { T1 } \\
\mathbb{N} \\
0 \\
0\end{array}$ \\
\hline
\end{tabular}


altura do $\mathrm{C} 1$, o que coincide também com o $\mathrm{C} 1$ do $\mathrm{T} 2$ e o $\mathrm{C} 1$ do $\mathrm{T} 4$. Outras camadas de concentração deste elemento no T1 ocorrem nos horizontes C3, C5 e C7, correspondentes aos $\mathrm{C} 3$ e $\mathrm{C} 4$ do $\mathrm{T} 2$, e com reflexo no horizonte $\mathrm{C} 2$ do T4. A presença destas camadas de maior concentração de Mn nos 4 perfis estudados vem confirmar a consistência do material originário.

$\mathrm{O}$ teor de $\mathrm{Na}$, na fração areia, tende a aumentar em profundidade porém em camadas específicas. Assim é que no T2 há maior concentração no $\mathrm{C} 1$ e $\mathrm{C} 4$, enquanto que no T4 esta concentração se manifesta nos horizontes Btgv3, C1g e C2, horizontes estes de máximo encharcamento. A ocorrência deste cátion na fração areia se deve aos plagioclásios calco-sódicos observados pela ocasião dos estudos em seção delgada e microscopia eletrônica de Varredura (MEV).

Tal resultado vem confirmar que a posição do T4, principalmente dos horizontes inferiores, é de condição termodinâmica de maior estabilidade para tais minerais. Em relação à concentração deste elemento no solo total (Tabela 4.9), é neglegivel, regra geral abaixo de $0.02 \%$ do óxido. Quanto a distribuição do $\mathrm{Ca}$ e do $\mathrm{Mg}$ em profundidade, note-se a mesma tendência para o sódio, com maiores concentrações nos horizontes inferiores do T4. Entretanto, a concentração destes elementos quando se leva em consideração o solo total é ligeiramente maior do que na fração areia contrariamente ao sódio. Em relação ao potássio ocorre situações diferentes do que a do $\mathrm{Na}, \mathrm{Ca}$ e $\mathrm{Mg}$, ou seja com concentrações relativamente elevadas tanto na fração areia como no solo. Tais resultados vem demonstrar que as micas estão presentes nas diversas frações do solo e são são herdadas principalmente do material de origem, presentes nas camadas de argilitos da Formação Irati. Tal fato foi constatado pelos exames das seções delgadas da microanálise.

\subsection{Mineralogia}

A difração de raios- $X$ para a fração areia indicou uma mineralogia pouco variável para todos os perfis estudados. No caso do $\mathrm{T} 1$, além do quartzo de espaçamentos mais intensos como os de $0.33 \mathrm{~nm}, 0.24,0.22,0.21,0.20,0.18$, e $0.16 \mathrm{~nm}$, 
ocorre os plagiocásios calco-sódicos com espaçamentos ao redor de 0.36 a $0.40 \mathrm{~nm}$ e de 0.41 a $0.42 \mathrm{~nm}$ para o ortoclásio (Figura 4.7). Tal mineralogia, pouco variável, vem confirmar a homogeneidade de todo este material. A presença de minerais intemperizáveis, como os plagioclásios, tanto no $\mathrm{T} 1$ como no $\mathrm{T} 4$ se deve a herança do material originário. No caso da fração silte, a mineralogia também é bastante simples, onde se inclui, além dos minerais citados para a fração areia, os minerais de 1,0 nm provavelmente as micas com picos de $1.0,0.5$ e $0.33 \mathrm{~nm}$ (Figura 4.8).

Em relação à fração argila os difratogramas tem indicado (Figuras 4.9 até 4.15) alguns pontos que devem ser considerados, a saber:

(a). A composição mineralógica do T1 ao T4 é constituido por caulinita, micas, vermiculita e esmectitas, tanto na superficie como na subsuperficie.

(b). Este resultado vem indicar que esses minerais foram herdado do material de origem principalmente o folhelho/argilito, rico nestes minerais (Moniz et al., 1995; Demattê, 1968)

(c) No caso das esmectitas o mineral ai presente, possivelmente seja a nontronita devido à presença do ferro na camada octaedral indicado pela micro análise das figuras $4.18 \mathrm{E}$, página $134 \mathrm{e}$ da micrografia- Figura $4.17 \mathrm{E}$ (página 128).

(d) Os difratogramas de raios- $\mathrm{X}$ indicam picos mal formados, largos e associados com outros espaçamentos, principalmente na faixa de 1.0 a 1,4 nm. Tais características indicam minerais pouco cristalizados (Buol et al., 1983; Wilding et al., 1983), o que vem salientar as condições de intemperismo reduzido destes perfis, principalmente no T4. Quanto a presença de espaçamentos na faixa de 1,2 a 1,3 nm se devem a minerais interestratificados principalmente mica + vermiculita com espaçamentos de 2,4 nm e, mica + esmectita com 2,2 nm (Estrada, 1971; Sawhney, 1989).

(e) Há entretanto alterações entre tais minerais a medida que o sistema de intemperismo evolui. Assim é que vindo dos horizontes mais inferiores do T1 em direção a superficie há um aumento no teor de caulinita e decréscimo no de minerais 2:1 num processo típico de dessilicatização (Tabela 4.11). Tal resultado pode ser compro 


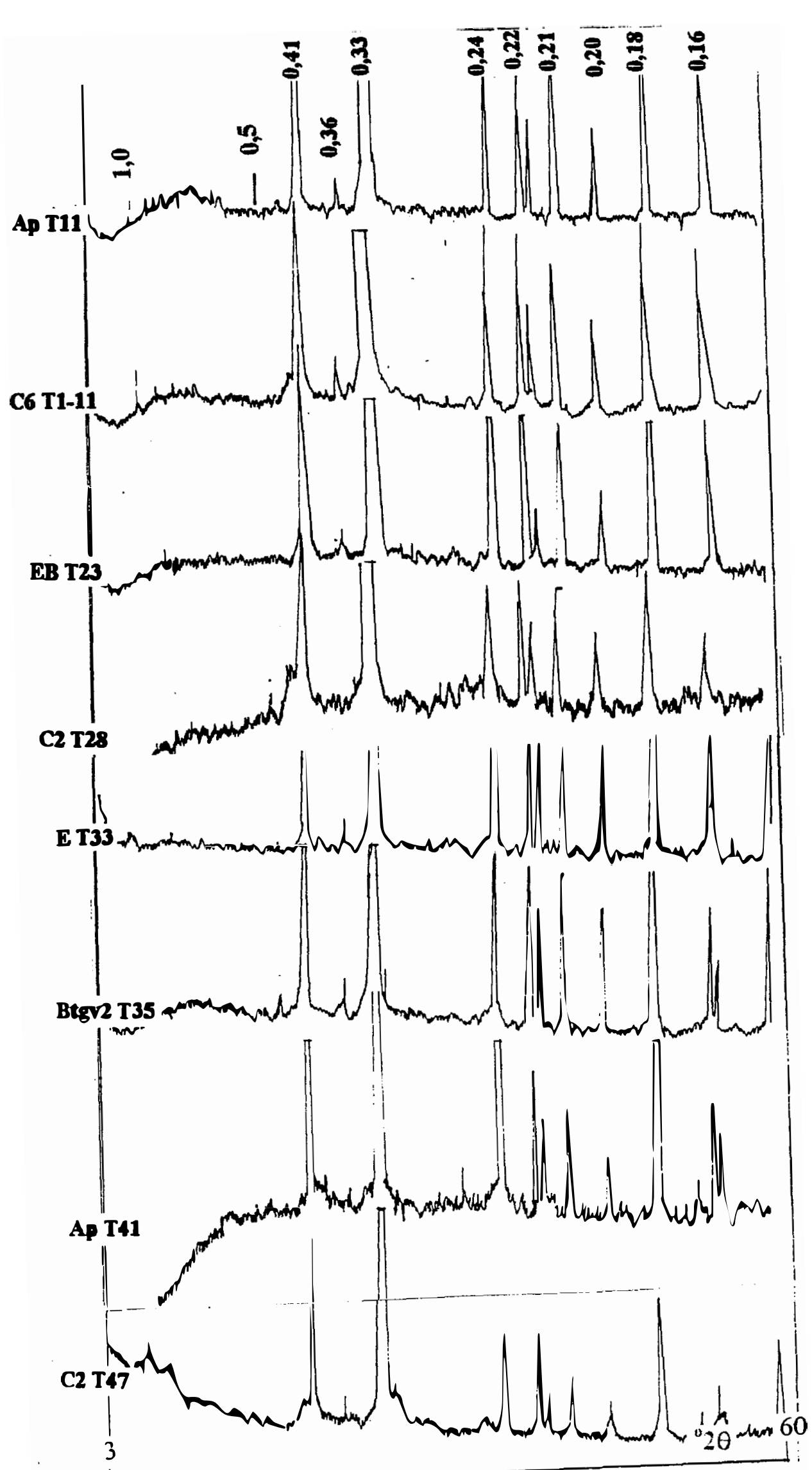

Figura 4.7. Difratogramas de raios- $X$ da fração areia em amostras deferradas dos perfis estudados. Espaçamentos em nanômetros. 


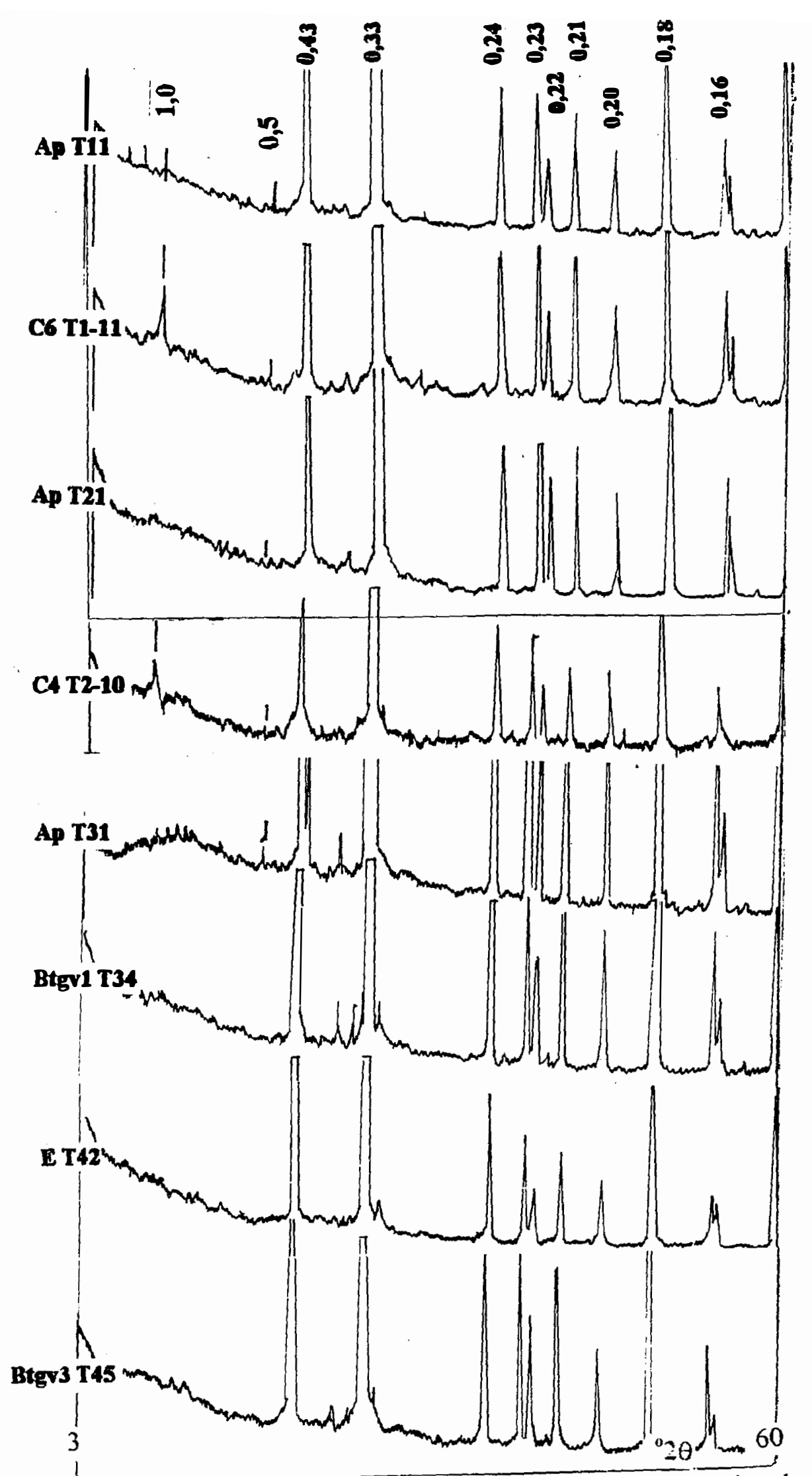

Figura 4.8. Difratogramas de raios- $\mathrm{X}$ da fração silte em amostras deferradas dos perfis estudados. Espaçamentos em nanômetros. 


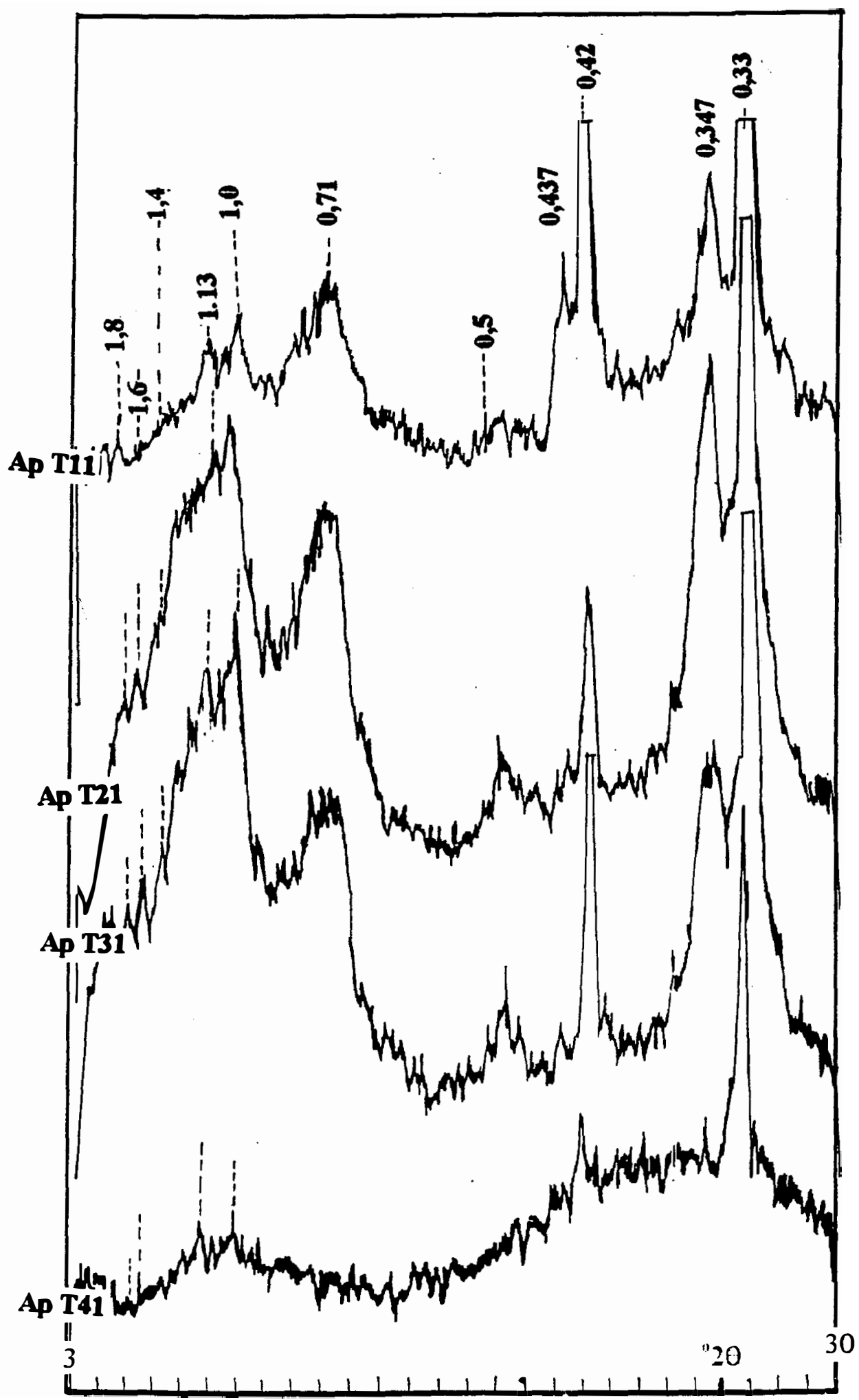

Figura 4.9. Difratogramas de raios- $\mathrm{X}$ da fração argila em amostras deferradas $\mathrm{K} 25^{\circ} \mathrm{C}$, dos horizontes Ap dos perfis T1, T2, T3 e T4. Espaçamentos em nanômetros. 


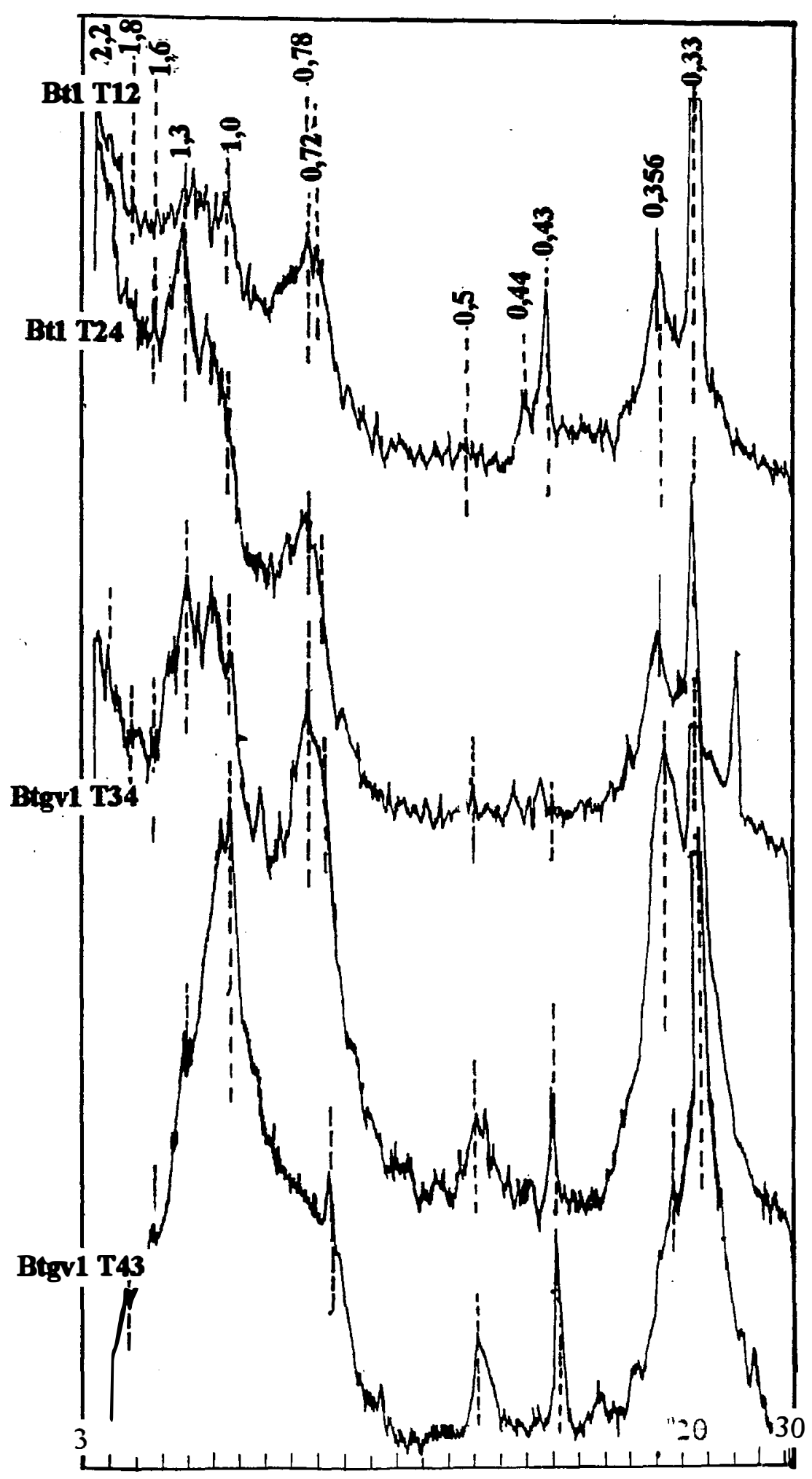

Figura 4.10. Difratogramas de raios- $X$ da fração argila em amostras deferradas $\mathrm{K} 25^{\circ} \mathrm{C}$, dos horizontes Btl(T1); Btl(T2); Btgvl(T3) e Btgvl(T4). Espaçamentos em nanômetros. 


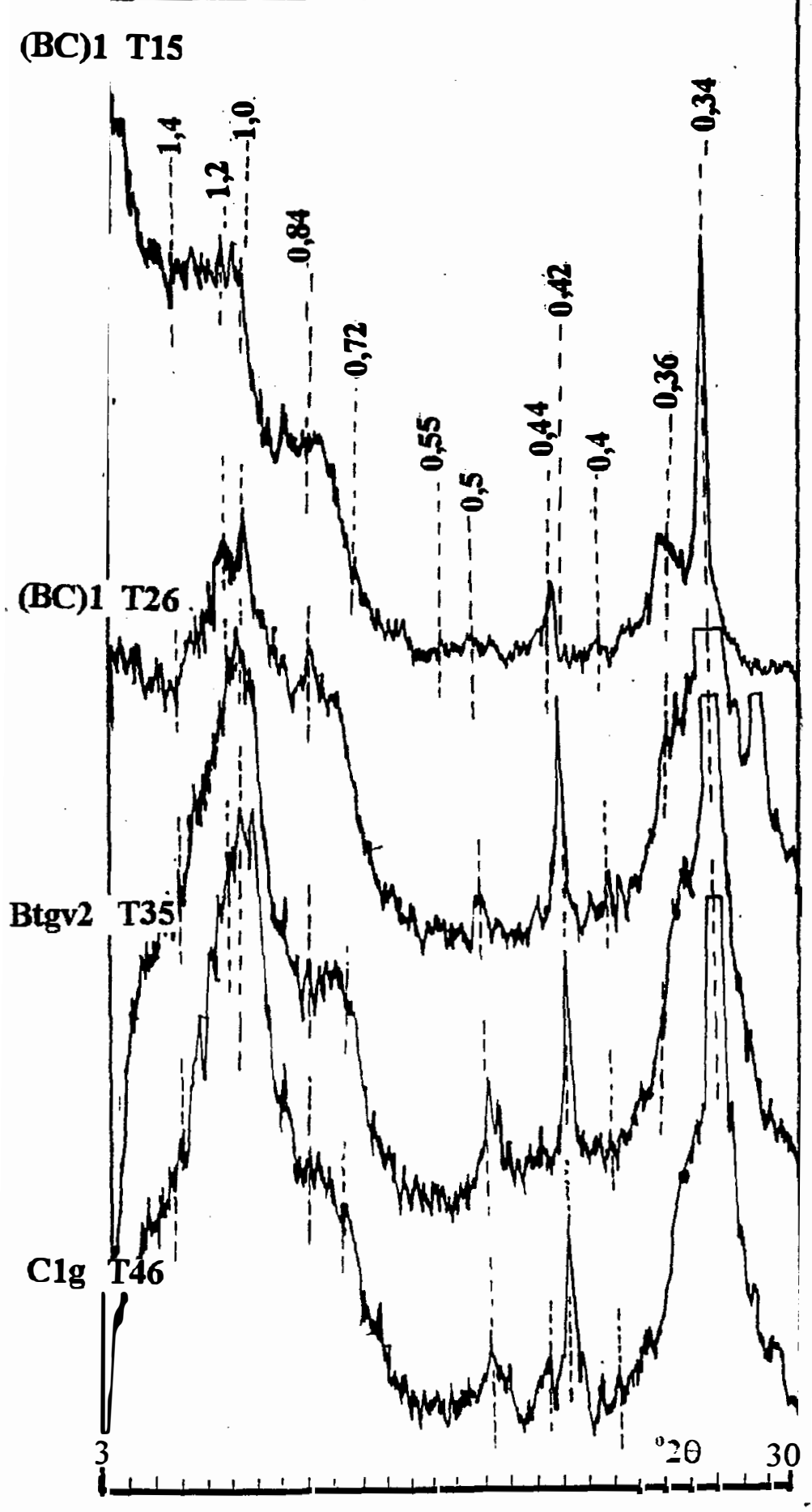

Figura 4.11. Difratogramas de raios- $X$ da fração argila em amostras deferradas $\mathrm{K} 25^{\circ} \mathrm{C}$, dos horizontes (BC)1-(T1); (BCg)l-(T2); Btgv2(T3) e $\quad$ Cll (T4).Espaçamentos em nanômetros 


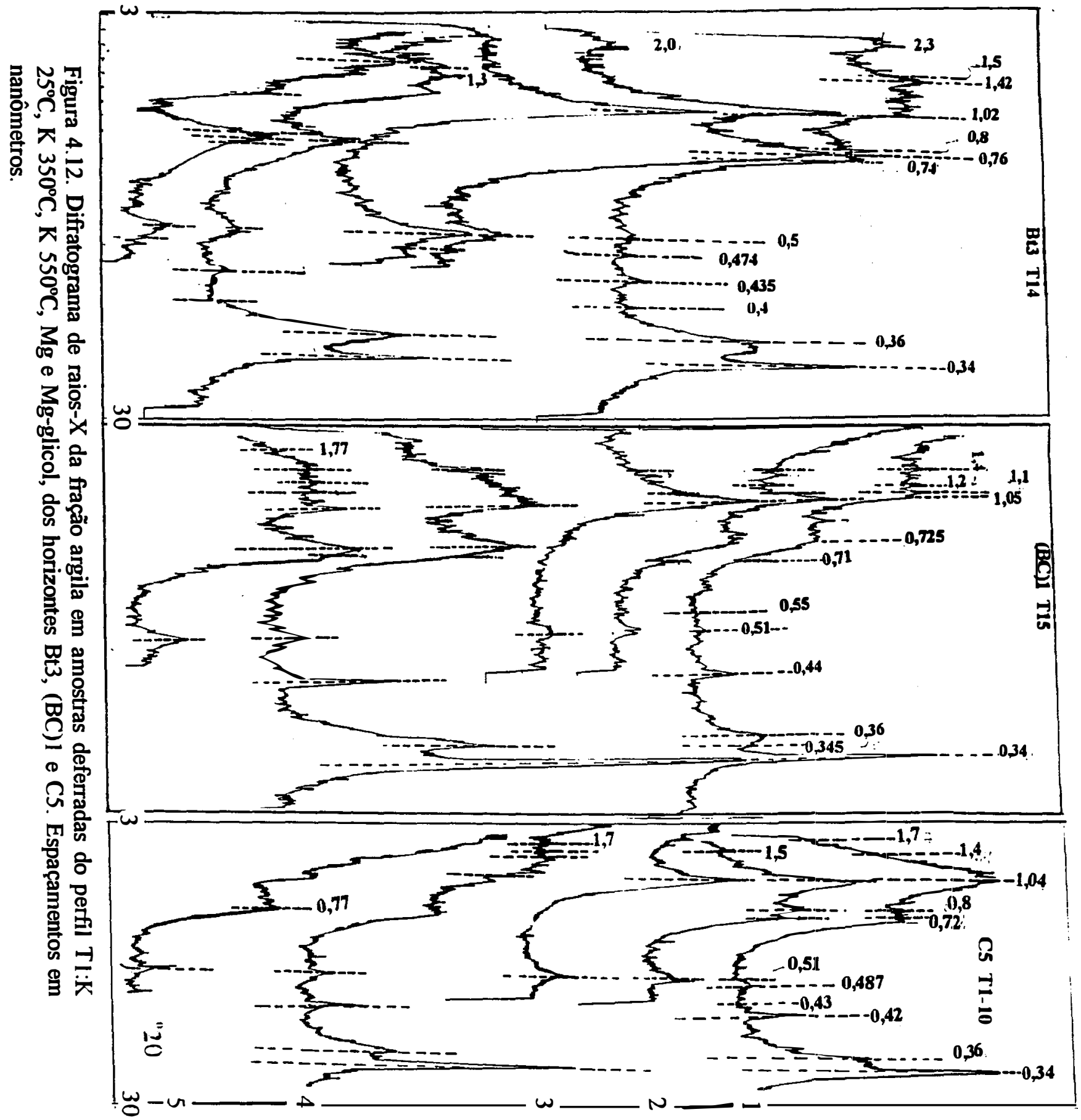




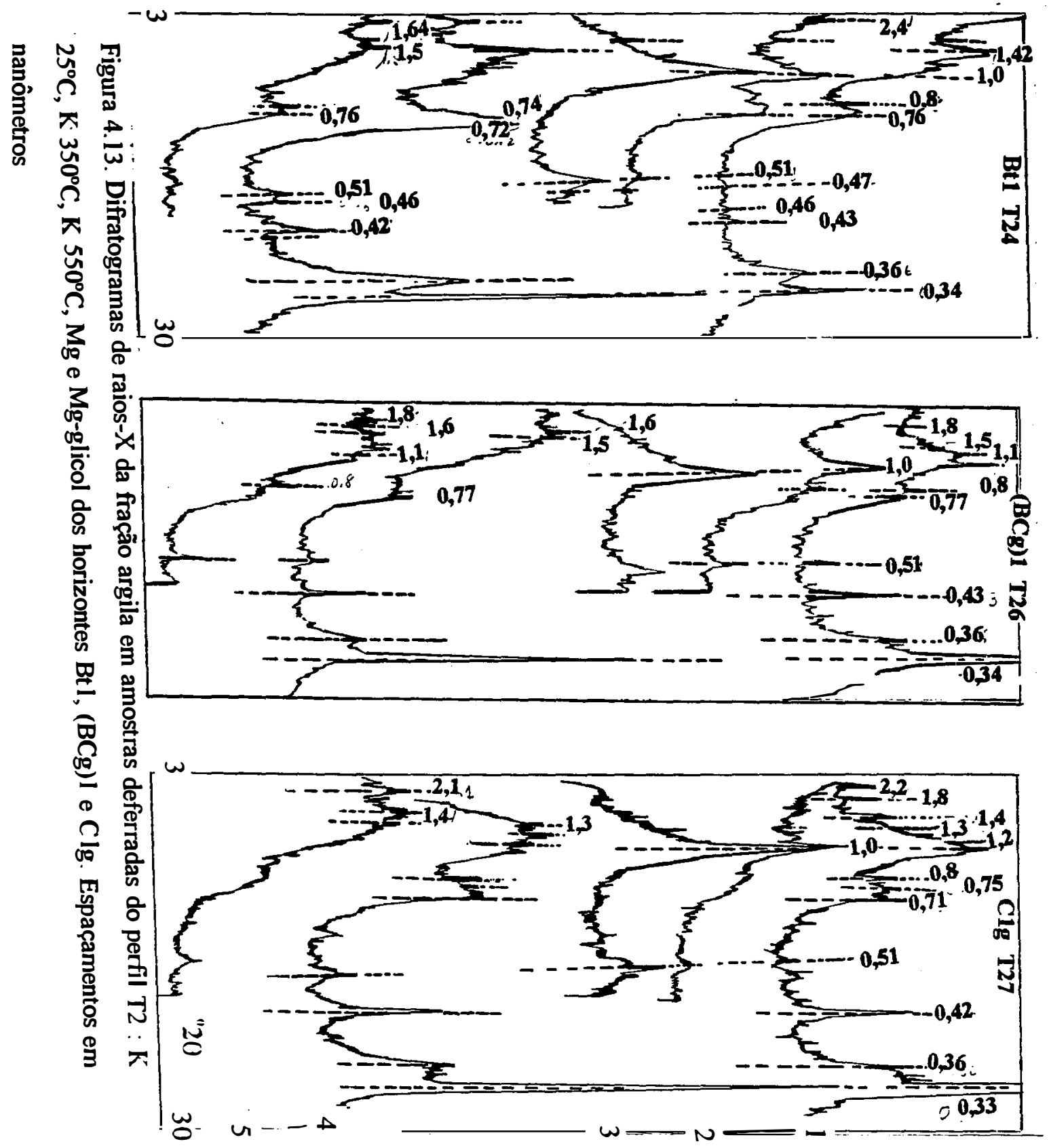




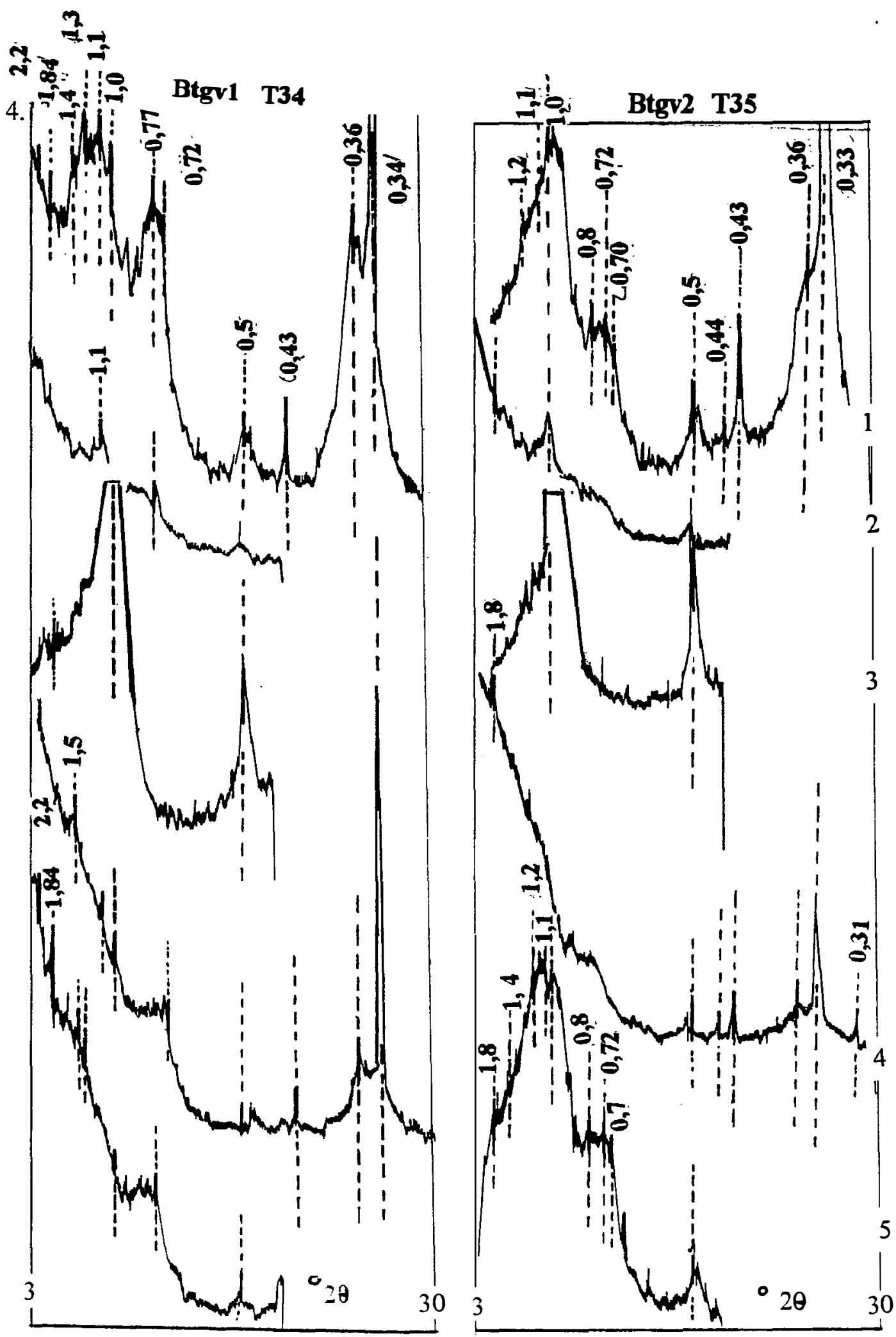

Figura 4.14. Difratogramas de raios- $X$ da fração argila em amostras deferradas do perfil T3: $\mathrm{K} 25^{\circ} \mathrm{C} ; 550^{\circ} \mathrm{C}$; Mg-Mg-glicol dos horizontes Btgvl e Btgv2. Espaçamentos em nanômetros. 

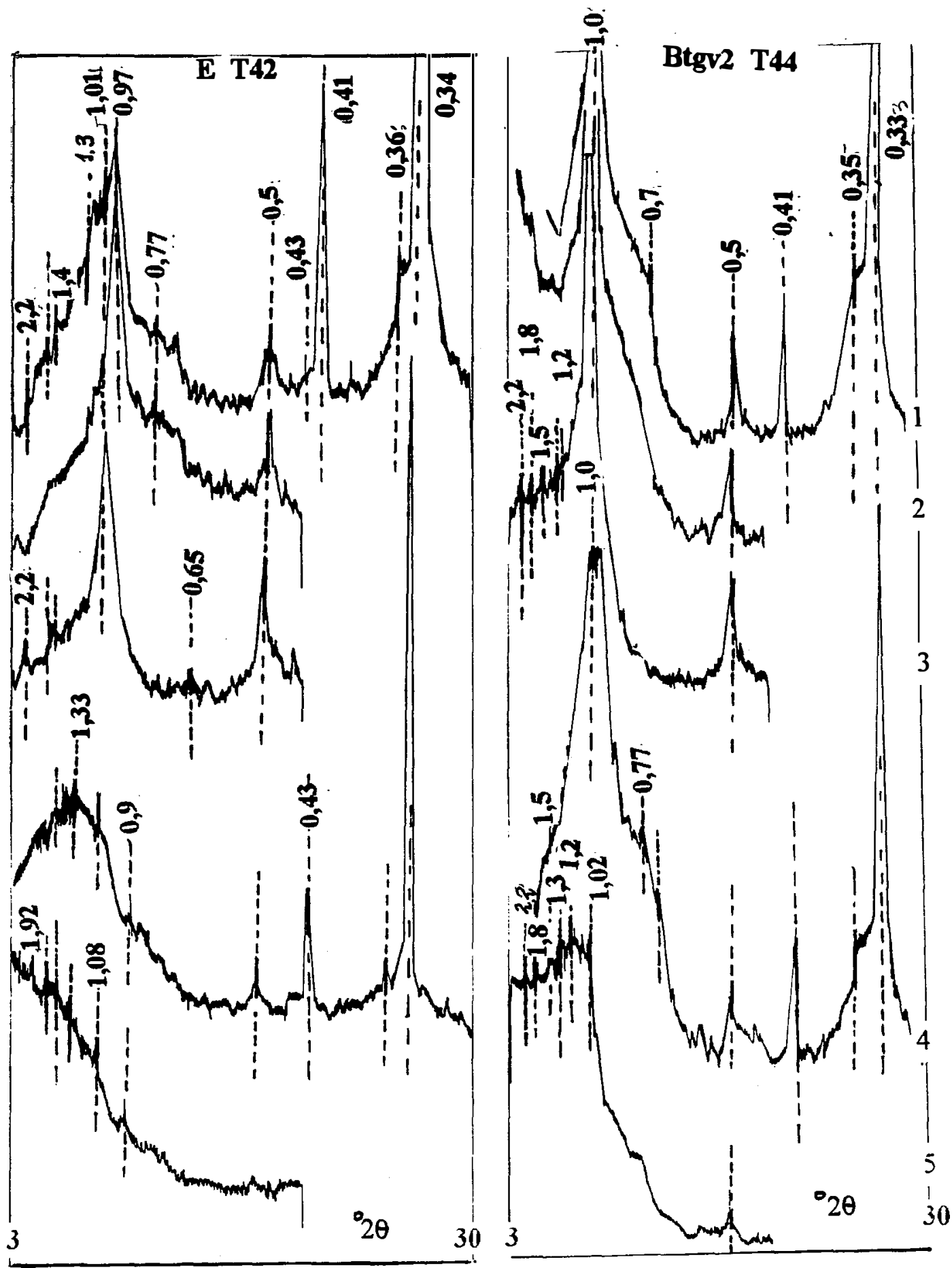

Figura 4.15. Difratogramas de raios- $X$ da fração em amostras deferradas argila do perfil T4: $\mathrm{K} 25^{\circ} \mathrm{C} ; \mathrm{K} 350^{\circ} \mathrm{C} ; \mathrm{K} 550^{\circ} \mathrm{C}$; $\mathrm{Mg}$ e $\mathrm{Mg}$-glicol dos horizontes $\mathrm{E}$, Btgvl. $\mathrm{C} 1 \mathrm{~g}$ e $\mathrm{C} 2$. Espaçamentos em nanôemetros. 

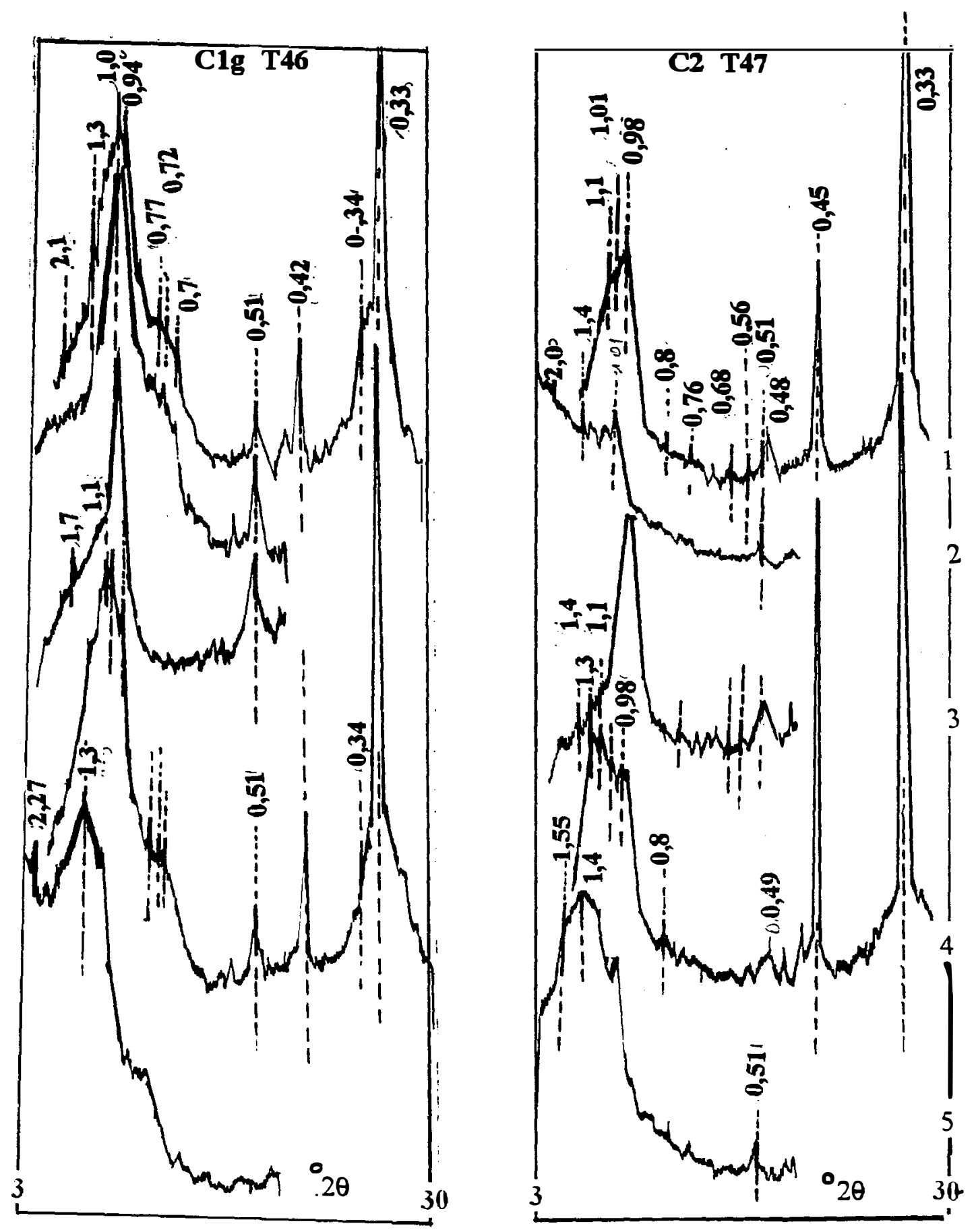

Figura 4.15. Continuação. 
vado pela redução da CTC (Tabela 4.4) onde os valores tendem a decrescer no sentido dos horizontes mais superficiais apesar do teor de argila não variar significativamente ou pelo aumento do teor de caulinita neste mesmo sentido Tal tendência se repete nos outros perfis. Na Tabela 4.10 pode-se observar outro resultado que pode auxiliar nesta visualização e que se refere as áreas dos picos da caulinita obtido nas análises térmica diferencial indicados na Figura 4.16. Assim é que as áreas dos picos da caulinta tendem a aumentar em direção a superficie, ou seja, aumentando o teor deste mineral.

(f) Por outro lado nos horizontes inferiores e na direção T1 ao T4 o processo do intemperismo se manifesta na direção da bissialitização. Observe que as áreas dos picos da caulinita dos horizontes inferiores do T1 decresce em direção ao T4 indicando uma maior estabilidade dos minerais 2:1 nesta direção.

Portanto, os dados indicam uma tendência de dessilicatização em direção à superfície dos solos para todos os perfis e uma tendência de bissialitização dos horizontes inferiores no sentido $\mathrm{T} 1$ ao $\mathrm{T} 4$, ou seja, do ambiente menos estável (do $\mathrm{T} 1$, bem drenado) ao mais estável (do T4 de drenagem impedida) (Lindsay, 1979).

As condições de bissialitização das áreas encharcadas, se deve ao maior valor da relação $\mathrm{Si} / \mathrm{Al}$ nesta região devido ao próprio processo de destruição parcial ou total dos minerais silicatados observados nos horizontes com encharcamento temporário. Entretanto o próprio quartzo, também por intemperismo, é fonte de silício como indica a micrografia da Figura $4.17 \mathrm{G}$ (pág. 128 ). Parte da origem das micas neste solos se deve a própria herança do material originário mas também pode ser formada por intemperismo do ortoclásio como indica a micrografia da Figura 4.17 I. (pág. 129). Nesta micrografia a mica é pseudomorfa do feldspato potássico. Como já foi salientado, o material de origem é rico em feldspato-K como indica a micrografia da Figura 4.17J.

A presença de material fossilizado é bastante comum nos horizontes destes solos numa clara evidência de material herdado das rochas de origem. As micrografias da figura 4.17F; 4.17K; 4.17L; 4.17M e 4.17N (pág. 126) indicam diversos materiais fossilizados. 
Tabela 4.10. Análise Térmica Diferencial de alguns horizontes diagnósticos da catena Saltinho.

\begin{tabular}{|c|c|c|c|c|}
\hline Horizonte & $\begin{array}{c}\text { Profundidade } \\
(\mathrm{cm})\end{array}$ & $\begin{array}{c}\text { Temperatura } \\
{ }^{\circ} \mathrm{C} \\
\end{array}$ & $\overline{\text { Mineral }}$ & $\%$ \\
\hline \multicolumn{5}{|c|}{ Perfil T-1 } \\
\hline Ap & $0-30$ & $\begin{array}{l}240 \\
500\end{array}$ & $\begin{array}{l}\text { Esmectita } \\
\text { Caulinita }\end{array}$ & - \\
\hline Bt2-w & $83-133$ & $\begin{array}{l}230 \\
520\end{array}$ & $\begin{array}{l}\text { Esmectita } \\
\text { Caulinita }\end{array}$ & $-\overline{61,0}$ \\
\hline \multicolumn{5}{|c|}{ Perfil T-2 } \\
\hline $\mathrm{Ap}$ & $0-30$ & $\begin{array}{l}240 \\
520\end{array}$ & $\begin{array}{l}\text { Esmectita } \\
\text { Caulinita }\end{array}$ & 63,5 \\
\hline EB & $45-60$ & 510 & Caulinita & 41,0 \\
\hline \multicolumn{5}{|c|}{ Perfil T-3 } \\
\hline Ap & $0-25$ & 510 & Caulinita & 30,7 \\
\hline $\mathrm{AE}$ & $25-38$ & $\begin{array}{l}230 \\
520\end{array}$ & $\begin{array}{l}\text { Esmectita } \\
\text { Caulinita }\end{array}$ & 29,1 \\
\hline E & $38-50$ & $\begin{array}{l}240 \\
520\end{array}$ & $\begin{array}{l}\text { Esmectita } \\
\text { Caulinita }\end{array}$ & 34,1 \\
\hline \multicolumn{5}{|c|}{ Perfil T-4 } \\
\hline Ap & $0-32$ & $\begin{array}{l}230 \\
510\end{array}$ & $\begin{array}{l}\text { Esmectita } \\
\text { Caulinita }\end{array}$ & 23,1 \\
\hline E & $32-58$ & $\begin{array}{l}230 \\
500\end{array}$ & $\begin{array}{l}\text { Esmectita } \\
\text { Caulinita }\end{array}$ & 23,6 \\
\hline Btgvl & $58-80$ & 550 & Caulinita & $\begin{array}{l}- \\
1,95\end{array}$ \\
\hline
\end{tabular}




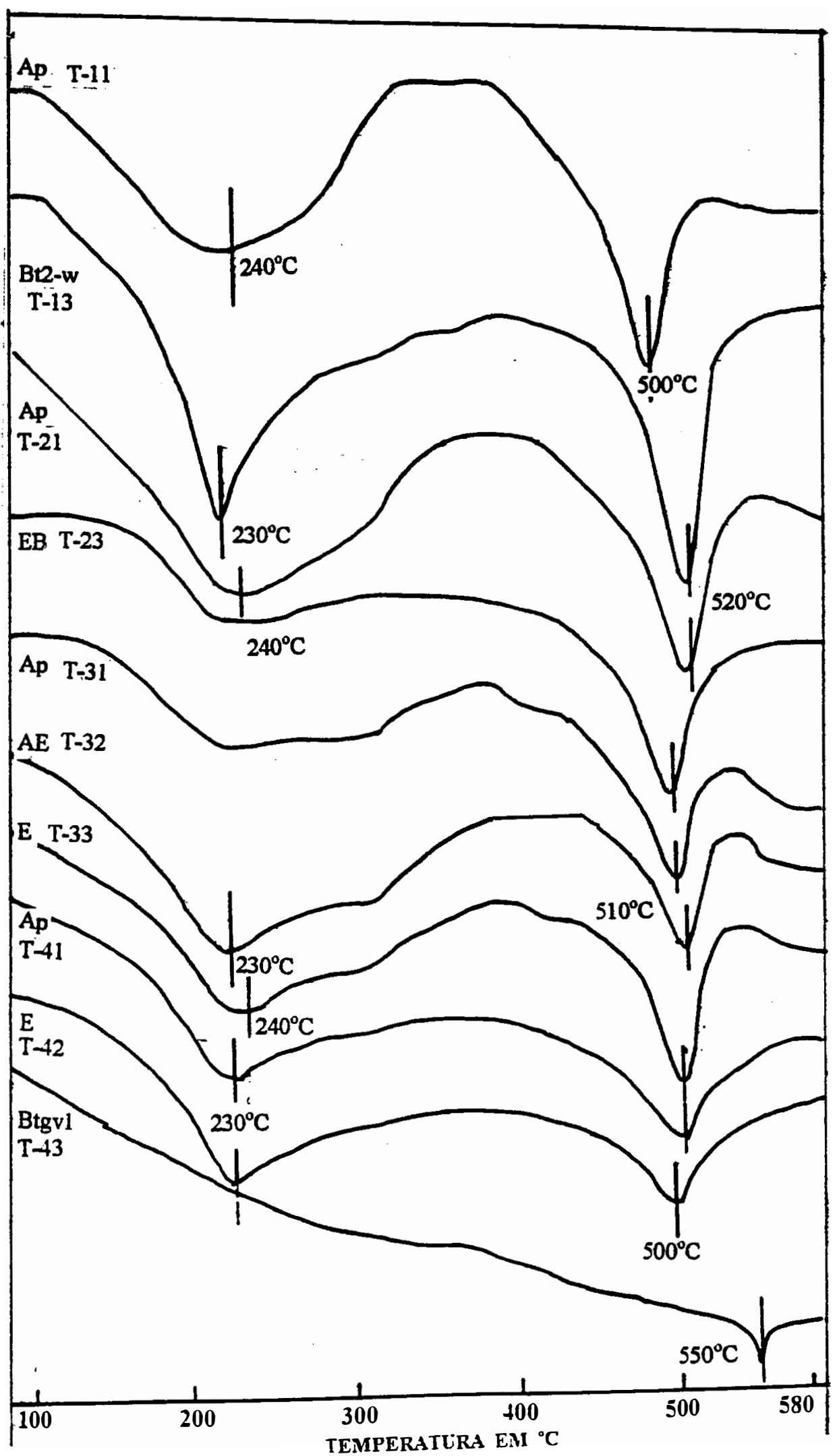

Figura 4.16. Termogramas em amostras deferradas da fração argila dos principais horizontes dos quatro perfis estudados mostrando os picos da caulinita e da esmectita e/ou vermiculita. 


\subsection{Processos genéticos envolvidos na seqüência estudada}

O material de origem da seqüência estudada é formado por camadas sucessivas de calcário associado com material sedimentar argiloso, no caso argilitos e material rico em manganês. Os dados granulométricos das relações areia fina/ areia total, areia muito fina/areia total e os teores de óxidos de titânio indicaram ser este material homogêneo. Nos trabalhos de campo não se observou entre o T1 e o T4 evidências de deposição superficial. A presença de lage de sílex, associada com as camadas de argilito de ocorrência na base dos perfis estudados, dificulta a drenagem vertical da água, e cria uma zona de oscilação da água na parte superior e uma zona de saturação permanente na parte inferior dos horizontes do T4 e T3.

A zona de oscilação do lençol freático e principalmente no período de novembro a abril tende a ficar saturada por mais de 60 dias, fato este comprovado pelas diversas idas ao campo, principalmente nas camadas superficiais do T3 e T4. Esta condição hidrodinâmica gera uma seqüência de ciclos de redução/oxidação responsáveis por grande parte dos processos genéticos envolvidos na seqüência. Como já foi salientado a área estudada corresponde a um modelo fechado segundo Ruhe (1969) sendo o $\mathrm{T} 1$ o membro correspondente ao perfil de boa drenagem e o T4 o membro da drenagem impedida e localizada na porção mais baixa da depressão fechada. Sendo assim todo o fluxo superficial e subsuperficial da água e solução do solo tende a se concentrar no T4. Apesar da área estudada ser considerada uma depressão fechada, principalmente no $\mathrm{T} 4$, há saída lenta da água no sentido vertical devido as fraturas existentes na lage de sílex, o que aliás é facilmente observado na jazida de calcário ao lado da área.

A alteração do argilito e /ou folhelho e os minerais primários ai presentes constitui inicialmente numa remoção do cimento, regra geral o ferro, liberando um material já por natureza argiloso (Demattê, 1970). Portanto os solos originados de tal material tendem a ser argilosos, aliás fato este observado em toda a região de Piracicaba onde ocorre tal material (Demattê, 1968; Moniz et al., 1995). Assim sendo a natureza dos perfis aqui estudados são argilosos. Observe os dados da fração argila do T1 (Tabela 
4.3) e note que em todo o perfil estudado, até no contato com a lage de sílex a classe textural é argilosa no Ap e muito argilosa no Bt, neste caso com teor de argila superior a $60 \%$, nos demais horizontes. As camadas $\mathrm{C} 1, \mathrm{C} 2, \mathrm{C} 3, \mathrm{C} 5$ e $\mathrm{C} 7$ têm teor de argila igual ou superior ao Bt1 e Bt2 deste perfil. A mineralogia de argila Tabela 4.11) tende a ser na região do material de origem rica em minerais 2:1 principalmente as micas e vermiculita e em alguns casos montmorilonita, confirmando as informações de Demattê (1970) e Moniz et al. (1995). Demais minerais primários além do quartzo foram identificados como os ortoclásios ricos em $\mathrm{K}$ e plagioclásios calco-sódicos.

Os resultados da CTC (Tabela 4.4) e da própria composição semiquantitativa da fração argila (Tabela 4.11) indicam tais tendências. Deduzindo-se a influência da matéria orgânica na CTC, note-se que principalmente para o T1 que o valor decresce em direção à superficie num nítido processo de dessilicatização (Jackson, 1969), com valores de Ki na faixa de 3.0 (Tabela 4,5) nos horizontes inferiores passando para a faixa de 2,0 no Ap. Tal processo, mais evidenciado no $\mathrm{T} 1$, se direciona unicamente por intemperismo vertical, sem ação dos processos de encharcamento, evideciando nos demais perfis, principalmente no T4. Os dados micromorfológicos dos horizontes $\mathrm{Bt}$ do $\mathrm{T} 1$ indicaram maior quantidade de cutans de iluviação do que nos demais perfis estudados, sugerindo que a formação do horizonte argilico deste perfil se procedeu principalmente por translocação vertical de argila.

A medida que se desloca do T1 para o T4 a ação das condições dos ambientes aeróbicos se manifestam e uma serie de reações se processam. Períodos de encharcamento do solo de 30 a 60 dias, já são suficientes para promover redução dos compostos de ferro (Van Breemen, 1988). A variação acentuada nos níveis de umidade é 
Tabela 4.11. Análise semi-quantitativa ${ }^{(*)}$ dos minerais da fração argila, em percentagem.

\begin{tabular}{lclllllll}
\hline \multicolumn{2}{l}{ Perfil T1 } & \multicolumn{2}{c}{ Perfil T2 } & \multicolumn{2}{c}{ Perfil T3 } & \multicolumn{2}{c}{ Perfil T4 } \\
\hline Horiz. & Minerais & Horiz. & \multicolumn{1}{l}{ Minerais } & Horiz. & Minerais & Horiz. & Minerais \\
\hline Ap & C4 M2 V1 E1 & Ap & C4 M2 V1 E1 & Ap & C3 M2 V1 E1 & Ap & C3 M3 V1 E1 \\
Bt2 & C4 M2 V1 E1 & Bt1 & C4 M2 V1 E1 & E & C3 M2 V1 E1 & E & C3 M3 V1 E2 \\
BC1 & C3 N3 V1 E2 & C2 & C3 M2 V1 E3 & Btgvl & C1 M4 V1 E2 & Btgvl & C1 M2 V1 E4 \\
C3 & C2 M4 V1 E2 & C4 & C2 M4 V1 E2 & & & Brgv2 & C1 M2 V1 E4 \\
C5 & C2 M4 V1 E2 & & & & C1g & C2 M4 V1 E2 \\
& & & & & C2 & C1 M4 V1 E2 \\
\hline
\end{tabular}

(*) $\mathrm{C}=$ Caulinita; $\mathrm{M}=$ Micas; $\mathrm{V}=$ Vermiculita; $\mathrm{E}=$ Esmectita.

1 : menor $10 \%$; 2 : $10-20 \%$; $3: 21-40 \% ; 4: 41-60 \%$.

constatada principalmente nos horizontes mais supeficiais do T3 e T4 associado com as evidências morfológicad de gleização é perefeitamente compatível, portanto, com a ocorrência de processos de oxi-redução principalmente dos compostos de ferro. Durante as oscilações do lençol freático, a oxidação ferro produz um aumento na concentração de ions $\mathrm{H}^{+}$, induzindo a protólise das lâminas dos minerais de argila tornando-os instáveis e possiveis de destruição total ou parcial. Aliás a redução expressiva dos teores de Fe-DCB nos horizontes E dos perfis T3 e T4 resulta dos processos de solubilização e remoção do ferro.

As conseqüências químicas e mineralógicas deste processo são as seguintes:

(a) Aumenta a concentração de $\mathrm{H}^{+}$na solução solo, abaixando o $\mathrm{pH}$ principalmente do T3 e T4 (Tabela 4.4).

(b) Desestabilização dos minerais da fração argila assim como das demais frações e posterior destruição parcial ou total de mineraais com aumento do teor de $\mathrm{Al}$ na solução do solo o que é comprovado pelos dados analíticos (Tabela 4.4).

(c) A redução na saturação das bases observado principalmente nos horizontes $\mathrm{Bt}$ dos perfis T3 e T4 se deve a ocupação pelo $\mathrm{Fe}^{2+}$ dos sítios de troca (Brinkman, 1970; Van Breemen, 1988) assim como pelo Al liberado na destruição dos argilominerais. 
Os cátions deslocados para a solução do solo são transportados para camadas mais profundas do perfil ou atravessando inclusive a lage de sílex (através das fendas).

Por outro lado as conseqüências morfológicas devidas a tais reações e mais particularmente relacionadas a cor do solo, tudo leva a crer numa transformação hematita para goethita uma vez que as cores se alteram do matiz 2,5YR 3/4 no T1 (típica da hematita) para matiz 10YR $3 / 4$ a 4/3 ou 6/2 (típica da goethita) como evidenciaram diversos autores (Schwertmann, 1971; Resende, 1976; Karmanova, 1981; Duchaufour, 1982; Schwertmann et al., 1982; Kämpf \& Schwertmann, 1982; Schwertmann \& Kämpf, 1985; Schwertmann \& Latham, 1986; Schwertmann, 1989) e constatado nas análises de raios $-\mathrm{X}$ (Figura Apêndice $3 \mathrm{~A}$ ).

O ambiente, na posição do $\mathrm{T} 4$, ao mesmo tempo favorecendo a instabilidade de alguns minerais, favorece a concentração de íons em solução tais como as bases, incluindo ai o $\mathrm{Na}$, a sílica e alúmina. Assim é que nas camadas superficiais, sujeitas as oscilações do lençol freático o ambiente é de instabilidade com destruição parcial ou total de minerais. Por outro lado nas áreas encharcadas, principalmente nos horizontes inferiores $\mathrm{Bt}$ do $\mathrm{T} 4$, o ambiente é mais estável e rico em íons, como foi visto. Com isso os minerais $2: 1$, herdados do material de origem não são destruídos, podendo até serem neoformados.

Com isso a CTC tende a ficar elevada (Tabela 4.4); atingindo valores extremos, superiores inclusive ao horizonte $\mathrm{C}$. Neste caso específico, observe que o teor de argila dos horizontes Bt do T4 é semelhantes ao do T1 enquanto a CTC passa da faixa dos 14,4 aos $17,8 \mathrm{cmol}_{c} \cdot \mathrm{kg}^{-1}$ no T1 para a faixa dos 34,5 a 41,8 $\mathrm{cmol}_{\mathrm{c}} \cdot \mathrm{kg}^{-1}$.

Tais resultados são indicativos de que o ambiente na região dos horizontes Bt do T4 favorece por um lado a estabilidade e por outro a formação de minerais 2:1 (Kämpf \& Klamt, 1978; Borchardt, 1989; Krasil'nikov, 1997). Esta elevada 
CTC, motivada principalmente pelos minerais $2: 1$, contribui para as formações de "slickensides" e da estrutura em cunha do Btgv. A ação de instabilidade provocada pelas condições de oxi-redução principalmente nas camadas superficiais do T3 e T4 provoca a destruição parcial dos argilominerais empobrecendo a camada superficial em argila assim como o clareamento na cor. As evidências para tal fato são as seguintes:

(a) Uniformidade no material de origem não indicando deposições superficiais.

(b) Teor de argila acima de $60 \%$ nos horizontes $\mathrm{B}$ do $\mathrm{T} 1$ ao $\mathrm{T} 4$.

(c) Redução no teor de argila dos horizontes superficiais do T1 ao T4. Passou de $59 \%$ no Ap do T1 a 42\% no T4 (Tabela 4.3). Aumento do gradiente textural neste sentido.

(d) Pouca evidência de translocação de argila nos perfis T2, T3 e T4. Os exames micromorfológicos indicaram a ocorrência de cutans de pressão no $\mathrm{Bt}$ e pouca quantidade de cutans de iluviação. A própria relação argila fina/argila total indica pouca translocação em profundidade, não suficiente para explicar a variação de $41 \%$ de argila do horizonte E do T4 para $67 \%$ no Btgvl. Aliás cuidados devem ser tomados na interpretação desta relação. Observe nos dados da Tabela 4.3, que os horizontes abaixo do $\mathrm{Bt}$ tanto no $\mathrm{T} 1$ como no $\mathrm{T} 4$, apresentam teores de argila fina ligeiramente superiores aos de argila grossa.

(e) Formação gradativa do horizonte E com máxima expressão no perfil T4.

(f) Evidências no horizonte $\mathrm{E}$ de material semelhante ao horizonte $\mathrm{B}$, como indicou nos exames morfológicos e micromorfológicos.

Sendo assim tudo leva a crer que a formação do elevado gradiente textural do T4 assim como do horizonte álbico se deu as custas da destruição do horizonte B. Seqüências semelhantes as aqui observadas têm sido publicadas na literatura tanto estrangeira como nacional (Bouma, 1983; Demattê et al., 1995; Almeida et al., 1997).

Estes foram os principais processos na diferenciação do horizonte $\mathrm{A}$ e $\mathrm{E}$ a partir do $\mathrm{Bt}$, causando muito provavelmente um rebaixamento no perfil ao longo da depressão em função da exportação do produto da destruição do ataque químico dos minerais do solo. 
Alguns aspectos sobre as características inerentes aos solos estudados relacionados a mineralogia podem ser observados nas micrografias e nas análises de miscrosondas. As principais são:

(a) Figuras 4.17 (A). Nesta figura a caulinita está revestindo os microcristais compostos de pirita framboidal no horizonte superficial do T1. Alias a pirita é um mineral comum no material de origem. O teor de ferro dos solos aqui estudados, principalmente no $\mathrm{T} 1$, se deve a decomposição da pirita. Na micrografia B desta mesma figura, observa-se hifas de fungos (forma de bastonetes) entremeando com cristais de caulinita. Os dados da microanálise indicados na Figura 4.18 A e B, ilustram uma possível análise da caulinita justamente nas micrografias da Figura 4.17 A e B. A micrografia (C) desta mesma figura indica a presença de opalas botroidais também no $\mathrm{T} 1$ disseminadas num meio rico em sílica. Os dados de microanálise indicam (Figura 4.18 C) dominância de sílica. Por sua vez na Figura 4.17 D há coexistência, numa mesma matriz de caulinita (cristais menores de forma pseudohexagonal) com a esmectita também no T1, horizonte BC. A microanálise pontual da Figura 4.18 E indica a presença do mineral 2:1 com Fe na camada octaedral.

(b) As micrografias contidas nas Figuras 4.17 correspondentes a horizontes selecionados do T1 indicam:

E- Mineral 2:1 possivelmente nontronita autigênica em crescimento e em forma de roseta. A microanalise apresentou além do $\mathrm{Al}$ e $\mathrm{Si}$ a presença do $\mathrm{Fe}$ caracterizando assim tal mineral 2:1 (Figura 4.18 E).

F - Algas diatomáceas fossilizadas circundando cristais de caulinita. A análise pontual indicou dominância de silício caracterizando assim o caráter de fóssil desta alga (Figura 4.18F).

G- Cristal de quartzo, corroído pelo intemperismo químico na camada C3 do perfil T1. Aliás a dissolução da sílica onde também se inclui o quartzo é comum em ambientes onde há presença de moléculas orgânicas particularmente ácido algimico e aminoácidos (Wilding et al., 1977). Também se atribui a dissolução do quartzo em solos 
ao material lixiviado rico em moléculas orgânicas. $O$ quartzo passa à solução como um complexo molecular Si orgânico. Tal fato vem corroborar a quase ausência das bonecas de sílex do T4 motivado pelo intenso intemperismo neste material.

H- Cristais de quartzo autigênico bem cristalizados com hábitos prismáticos e faces piramidais, no perfil T1 camada C3 (microanálise na Figura 4.18H). (c). As micrografias obtidas no microscópio eletrônico de Varredura do T1 da Figura 4.17 indica o seguinte:

I- A posição central é ocupada por cristal de mica pseudomórfico do feldspato- K circundado por camadas de sílica. Os picos espectrais da microanálise caracterizam a mica que contem pequena substituição pelo $\mathrm{Fe}$ na camada octaedral (Figura $4.18 \mathrm{I}$ ).

J- A posição central ilustra um cristal de ortoclásio, se intemperizando possivelmente para micas (microanálise na Figura 4.18J).

(d). As micrografias contidas na Figura 4.17 representando o perfil T4 indicam a presença de fitolitos de formas cilíndricas ( $\mathrm{K}$ e L) e laminares ( $\mathrm{M}$ e $\mathrm{N}$ ), devidamente identificado pelas microanálises contidas na Figura 4.18 K, L, M e N. Trabalhos em fitolitos indicam que a sílica é depositada em forma opalina ou opala biogênica, dentro dos tecidos das plantas, como reforçamento das estruturas celulares ou recheio das células epidérmicas (Jones \& Handreck, 1963; Elgawhary \& Lindsay, 1972; Mckeague \& Cline, 1963; Pease \& Anderson, 1969; Verma \& Rust, 1969; Jones, 1969; Yeck \& Gray, 1972).

(e) As Figuras 4.17e 4.18 resumem uma serie de micrografias e microanáilses do perfil T4, a saber:

O -Representa cristais de plagioclásio potássico (identificado pela microanálise da (Figura 4.18 O).

P - Concreções de manganês numa matriz rica em sílica (Figura 4.18 P).

Q - Folhas (semelhantes a um livro) de micas (Figura 4.18 Q).

R - Cristais de pirolusita associados à manganita (Figura 4.18 R). 
Figuras 4.17.

Micrografias (MEV) de diferentes horizontes e camadas dos solos estudados 


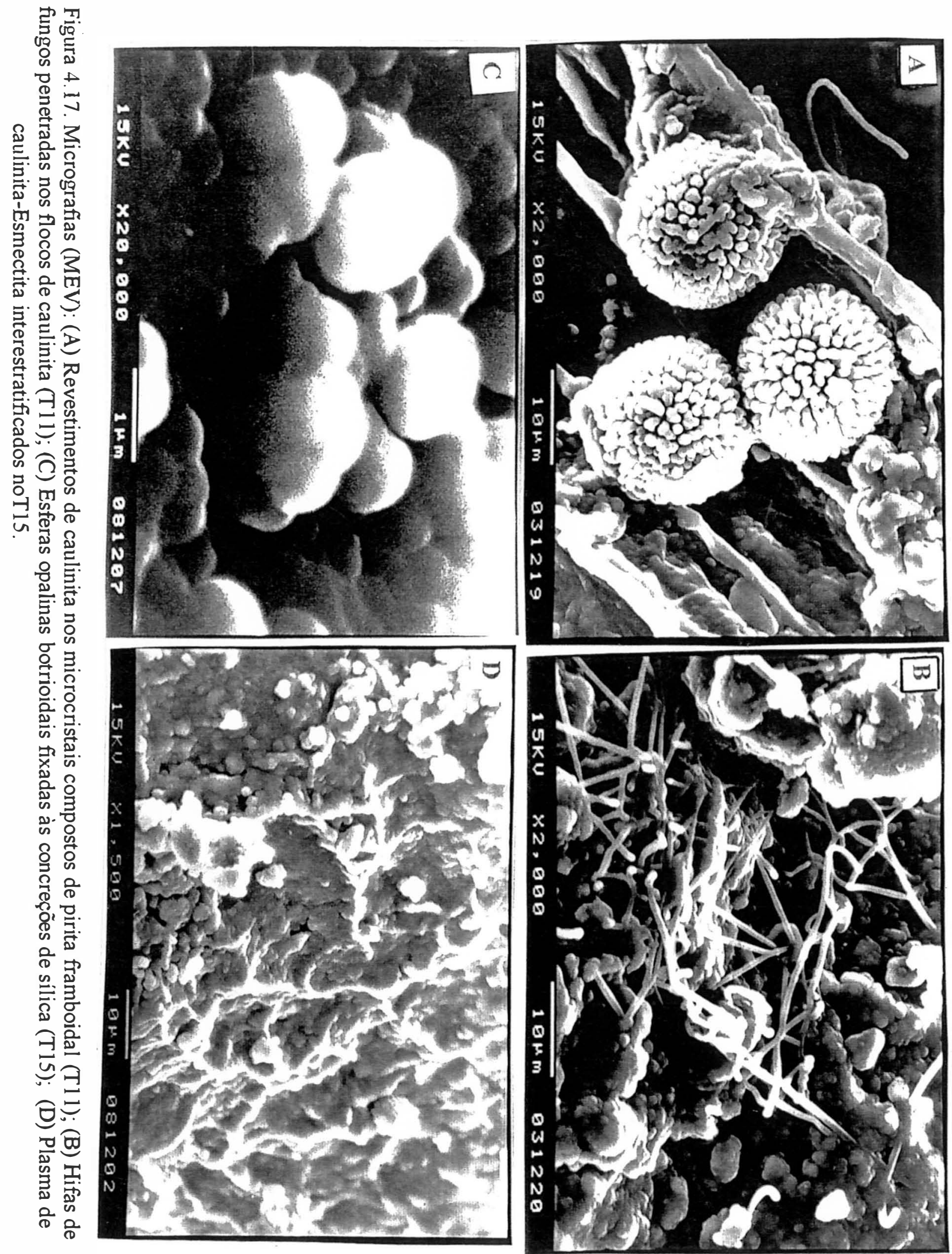



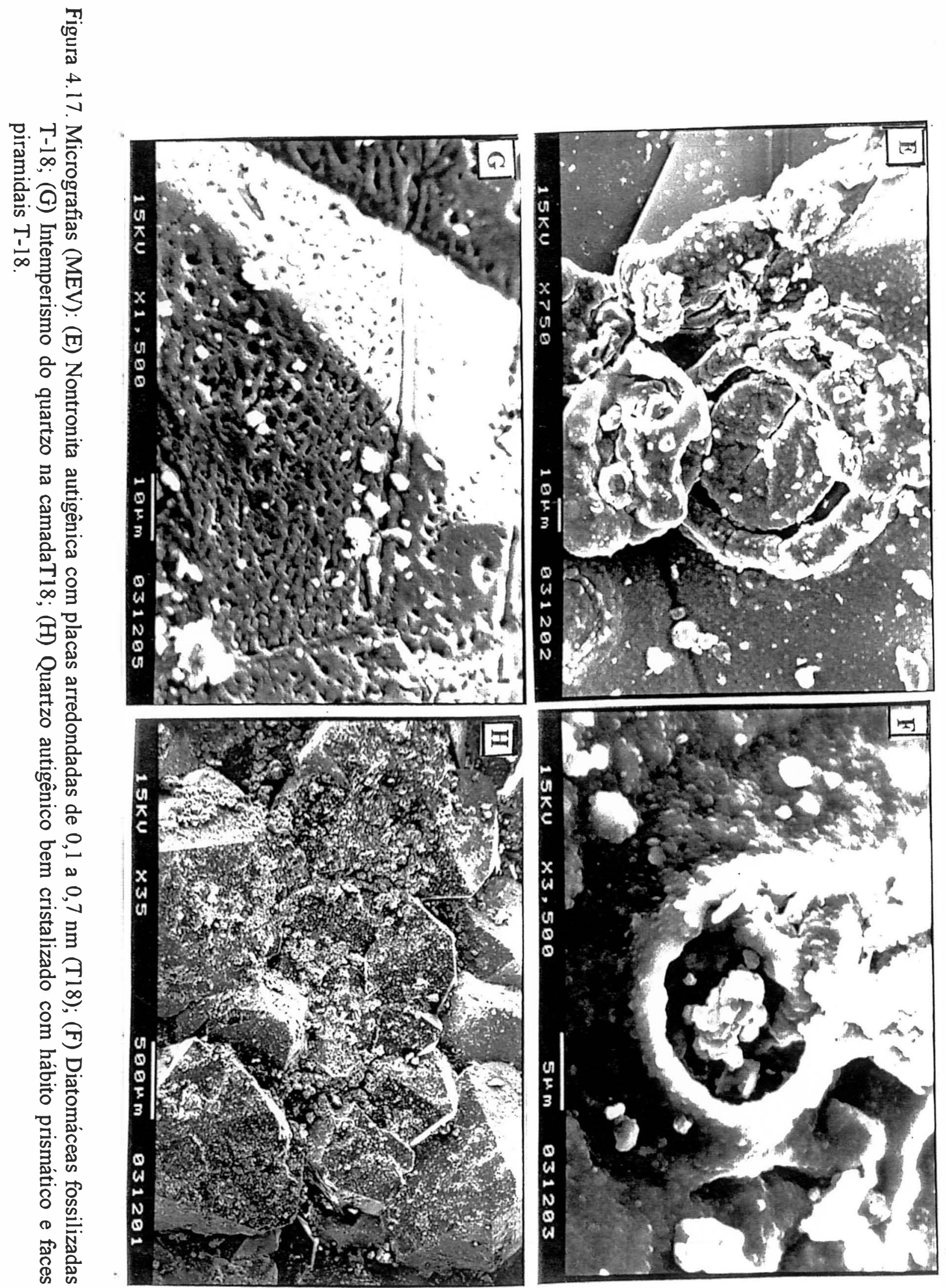


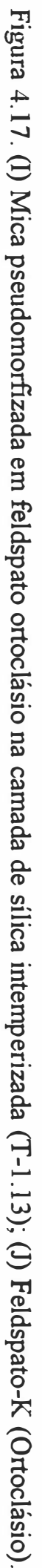
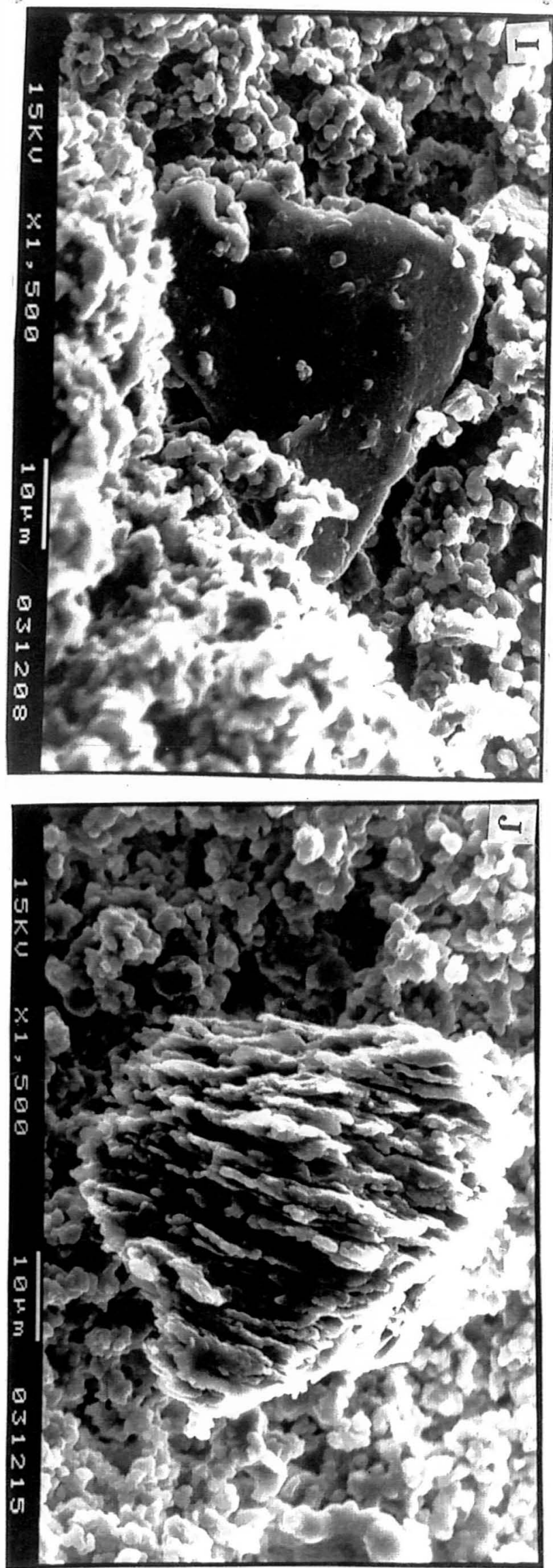


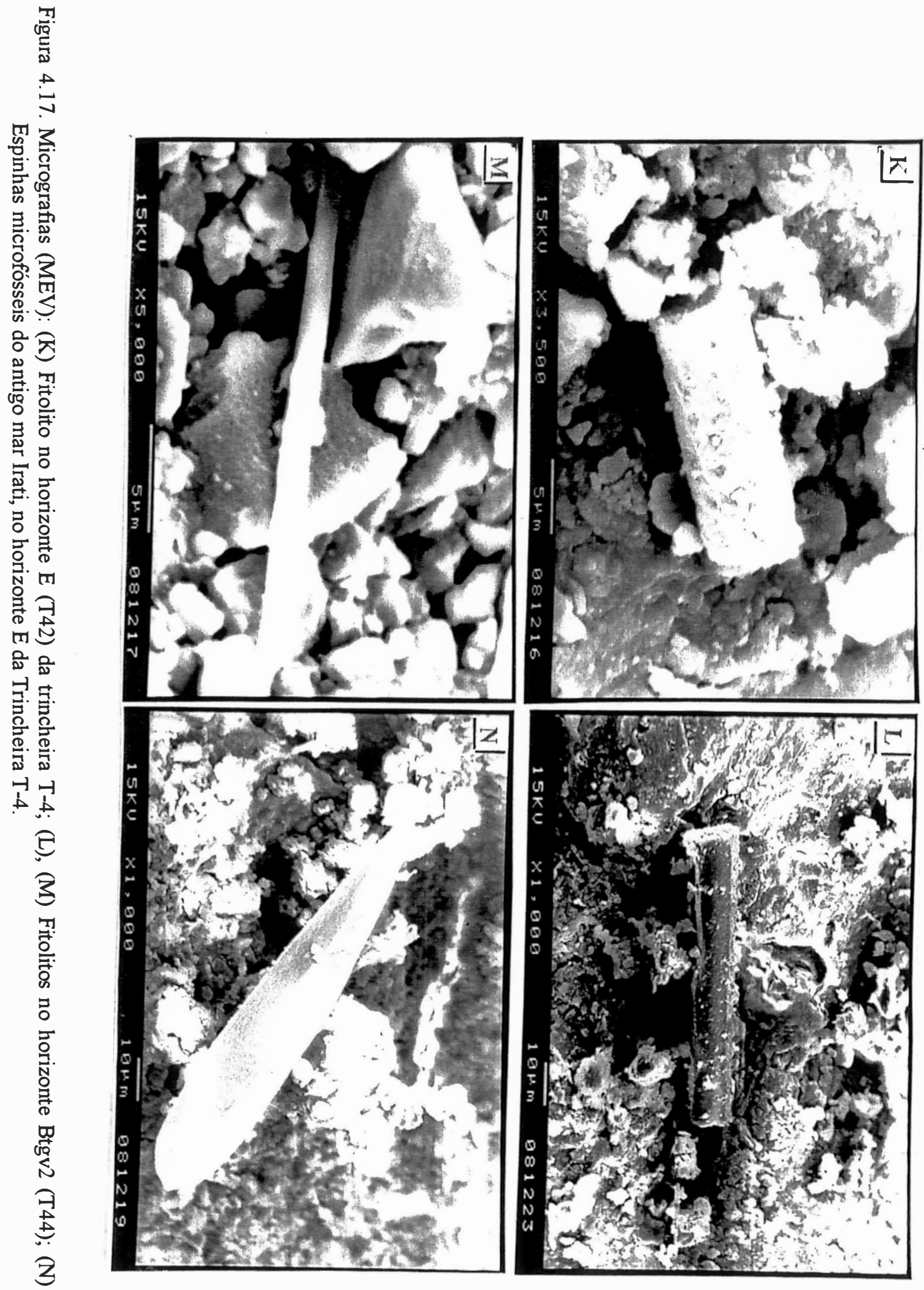




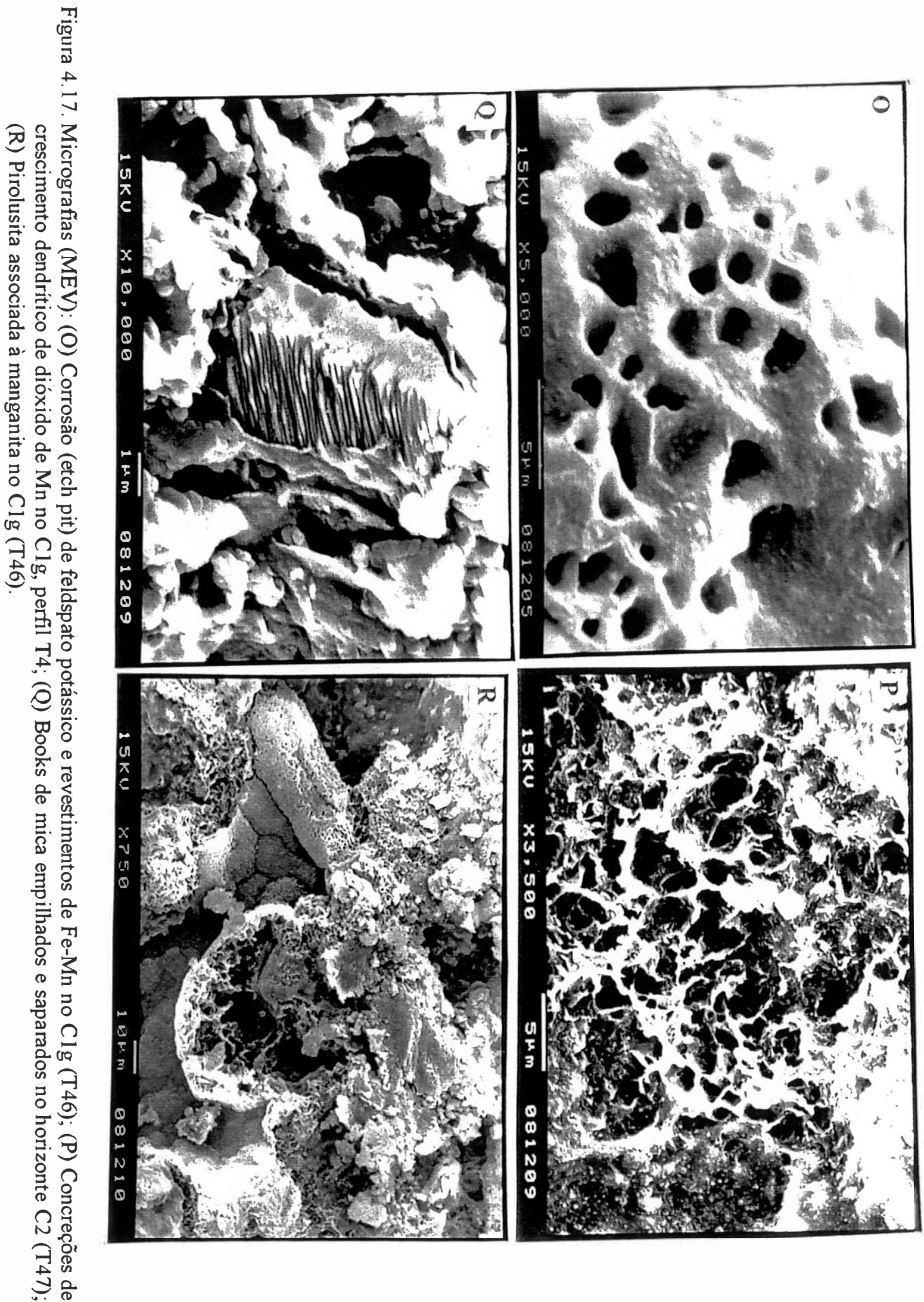


Figuras 4.18.

Picos espectrais da microanálise das micrografias (MEV) nos perfis estudados. 
QUALITATIVE ELEMENT IDENTIFICATIOH

SAMPLE ID:T-11- FOTO 18

POSSIBLE IDENTIFICATION

SI KA OR SR LA?

CA K KA

AL KA OR BR LA?

PEAK LISTINE

$\begin{array}{cccc} & \text { ENERGY } & \text { AREA EL. AND LINE } \\ 1 & 1.480 & 225 \text { AL KA OR BR LA? } \\ 2 & 1.750 & 807 \text { SI KA OR SR LA? } \\ 3 & 3.706 & 435 \text { CA KA }\end{array}$

$\pi t-500$

LED 03-DEC-97 17:03

Sursor: $0.000 \mathrm{keV}=0$
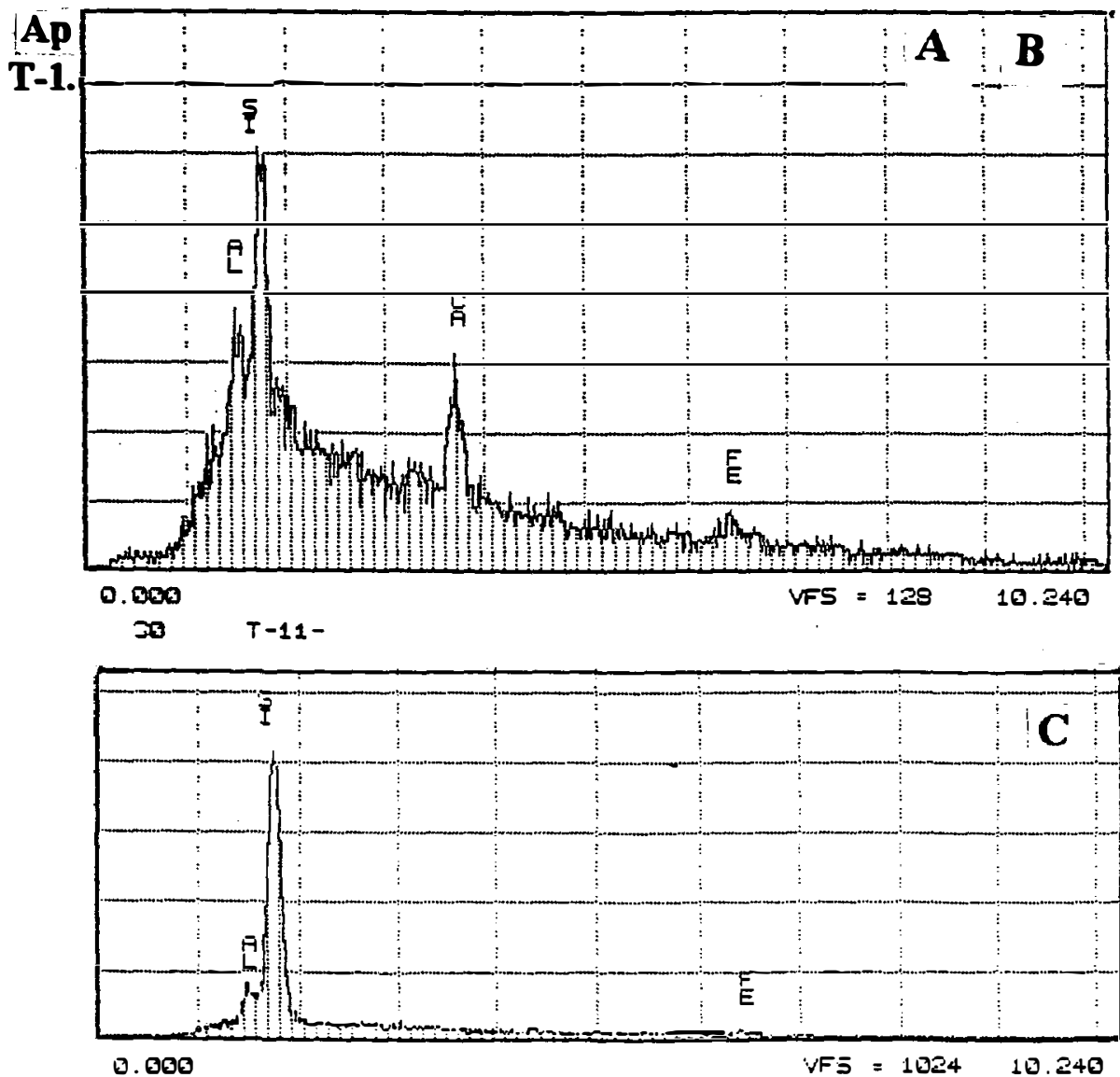

$$
20 \quad T-15
$$

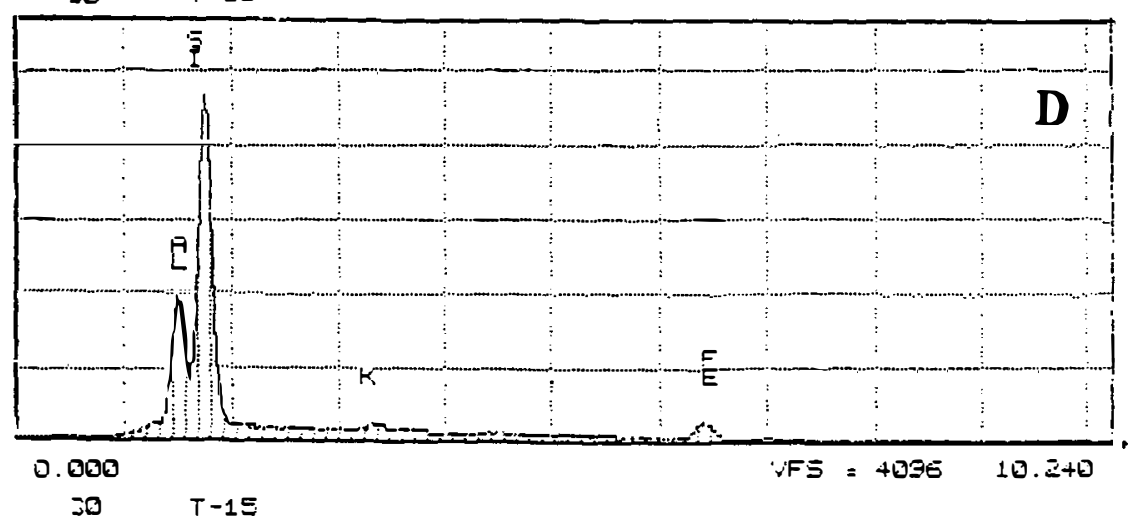

Figura 4.18. Picos espectrais da microanálise (MEV) das micrografias A, B, C e D. 


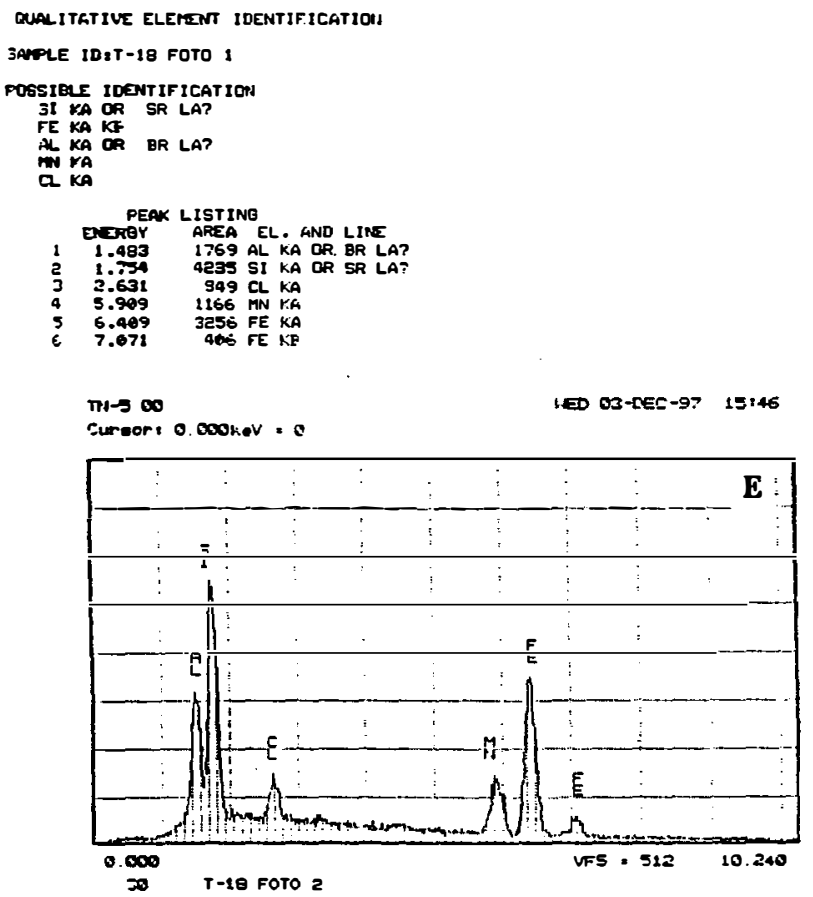

OUKLITATIVE ELEHENT IDENTIFICATICHA SAPLE 10:T-18 FOTO 3 FOSSIDUE IDENTIFICATICW
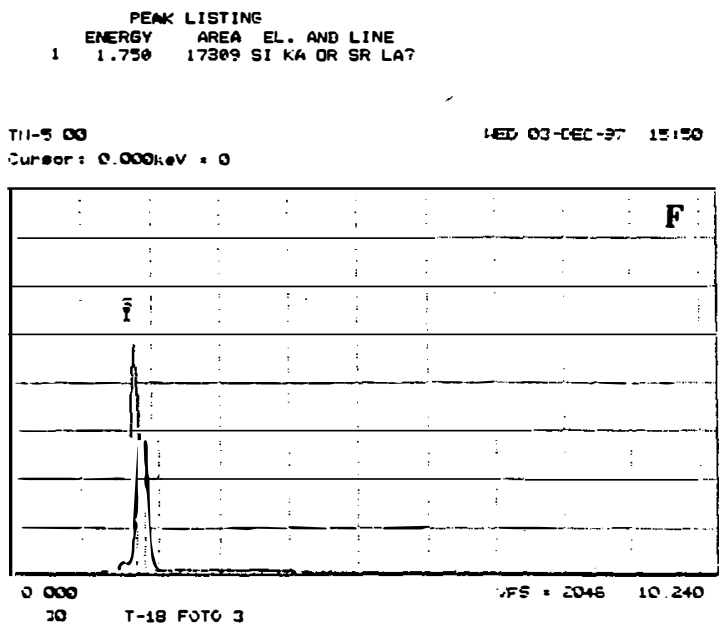

QUALITATIVE ELEMENT IDENTIFICATIOI

SAMPLE ID:T-12 FOTO 1

POSEIBLE IUENTIFICATION

SI K.A OR SR LA?

AL KA OR BR LA

QUALITATIVE ELEMENT
IAMPLE ID:T-1S FOTO 4

SOSEIQLE IDENTIFICATION

SI KA OR SR LA?

FEAK. LISTINE

ENERGY AREA EL. ANE LINE

1 1.75e 21141 SI KA ON SK LA?
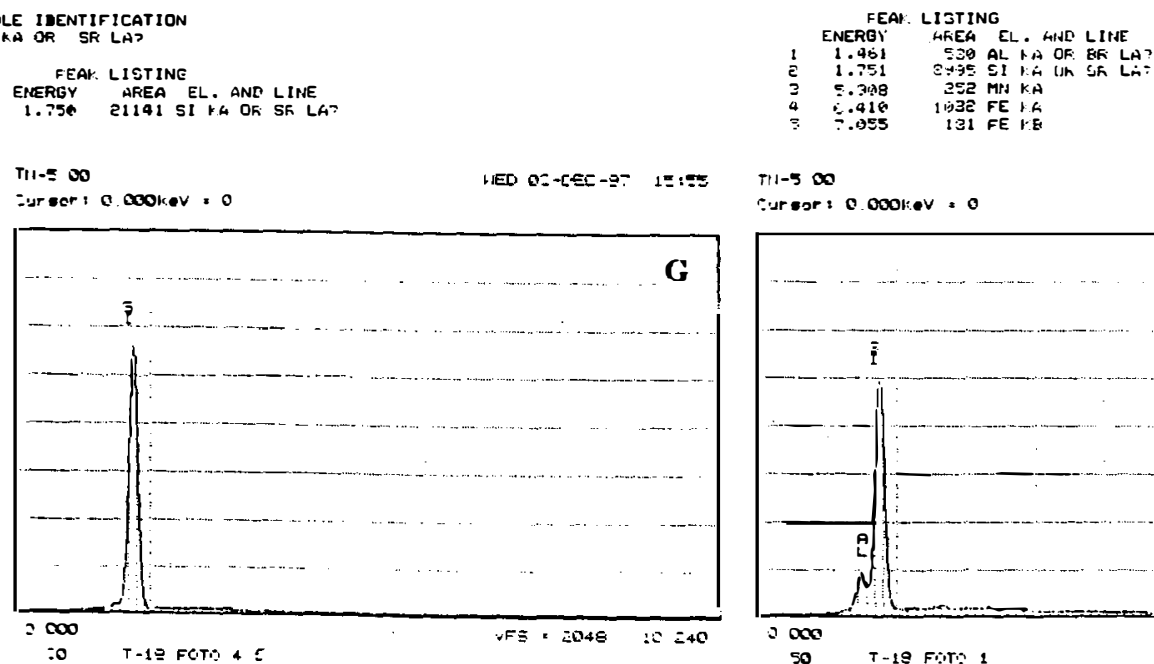

Thi-s 0

Cureor: $0.000 \mathrm{kev}=0$

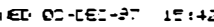

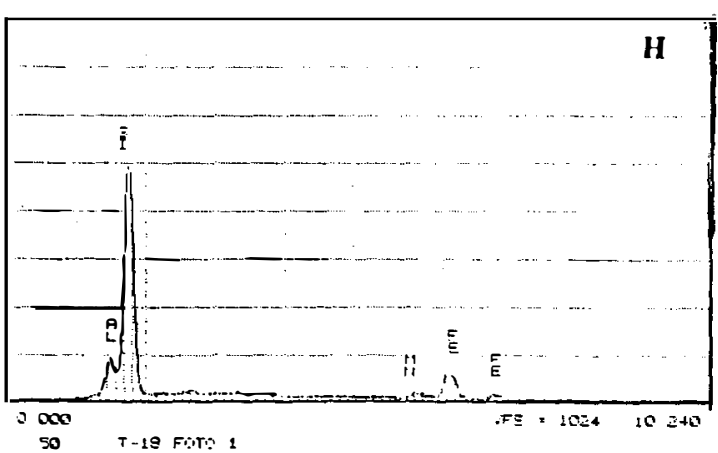

Figuras 4.18. Picos espectrais da microanálise das micrografias (MEV) E, F, G, H. 

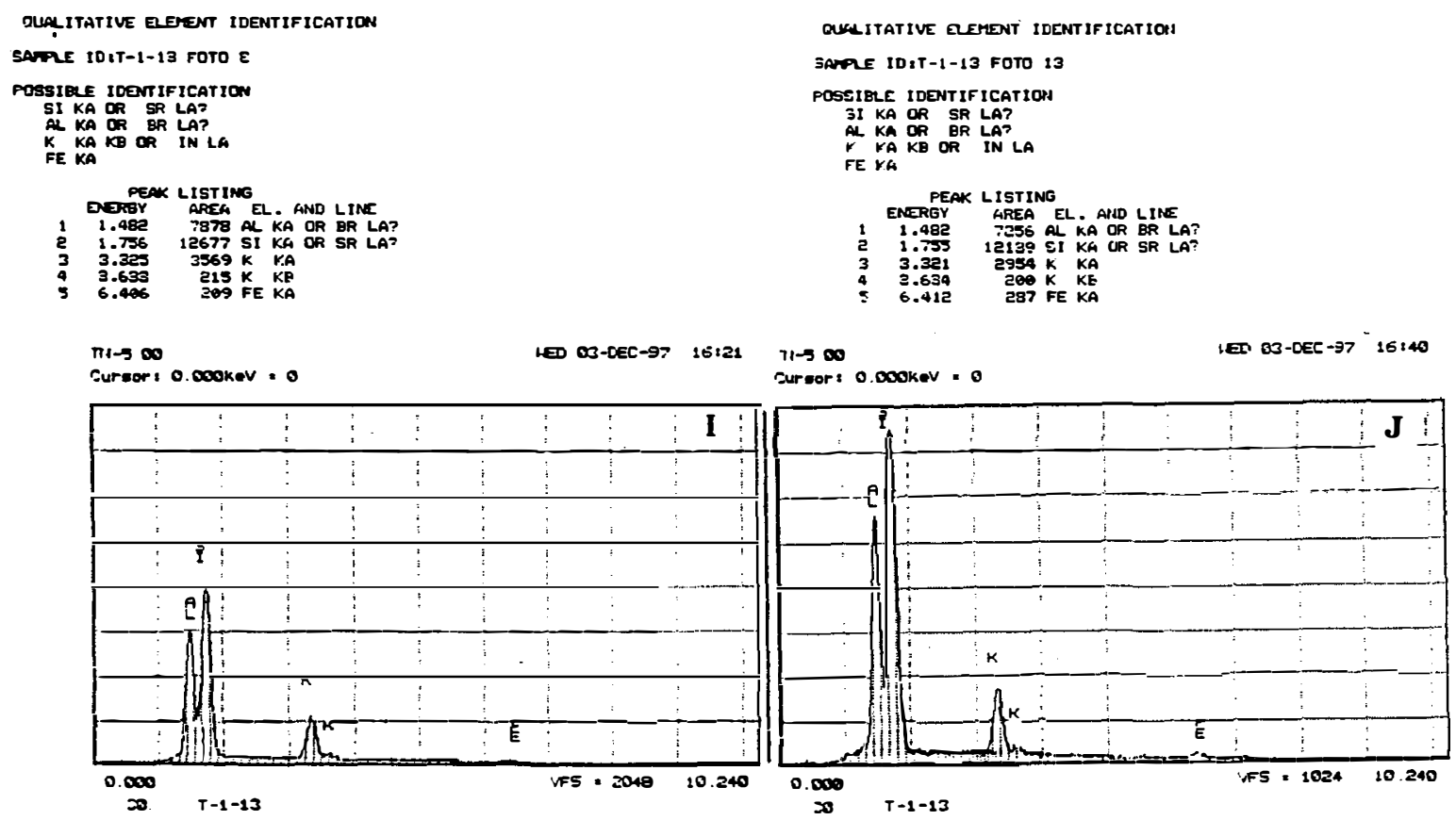

QUALITATIVE ELEMENT IDENTIFICGTICM,

SAMPLE IDIT-42

OOSEIBLE IDENTIFICATION

$31 \mathrm{KA}$

MB LA OR AU LA MA \& ESCAPE REAK

PEAK LISTINI

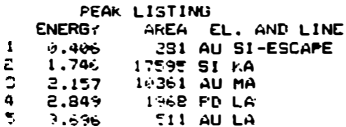

$T-1-13$

CUILITATIVE ELEMENT IDENTIF ICATIOA

SAMPLE ID IT-44

F.OSEIBLE IOENTIFICATIONA

We LA OK GU LA TAM

CL KE OR PD LA

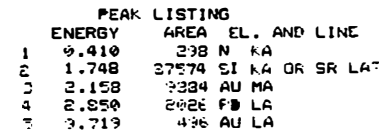

Ti-e $\infty$
sursor: c ceouer $=0$

$\because S E$ FO LA

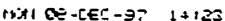

til-s $\infty$

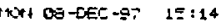

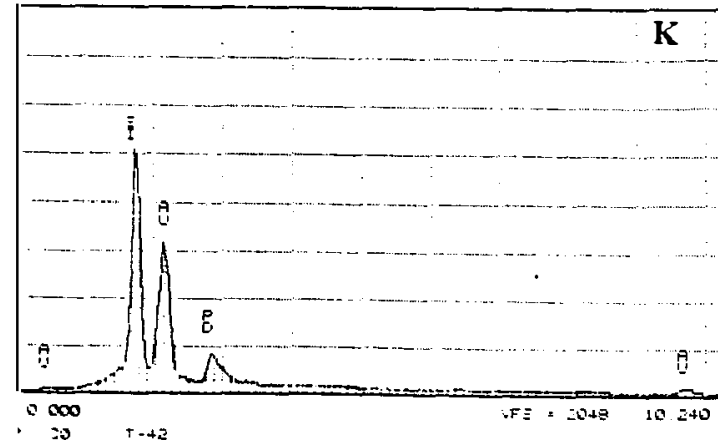

Tursor: 0 oookev $=0$

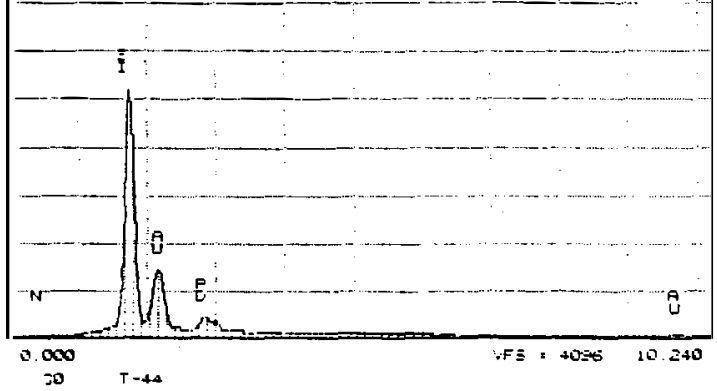

Figuras 4.18. Picos espectrais da microanálise das micrografias (MEV) I, J, K e L. 

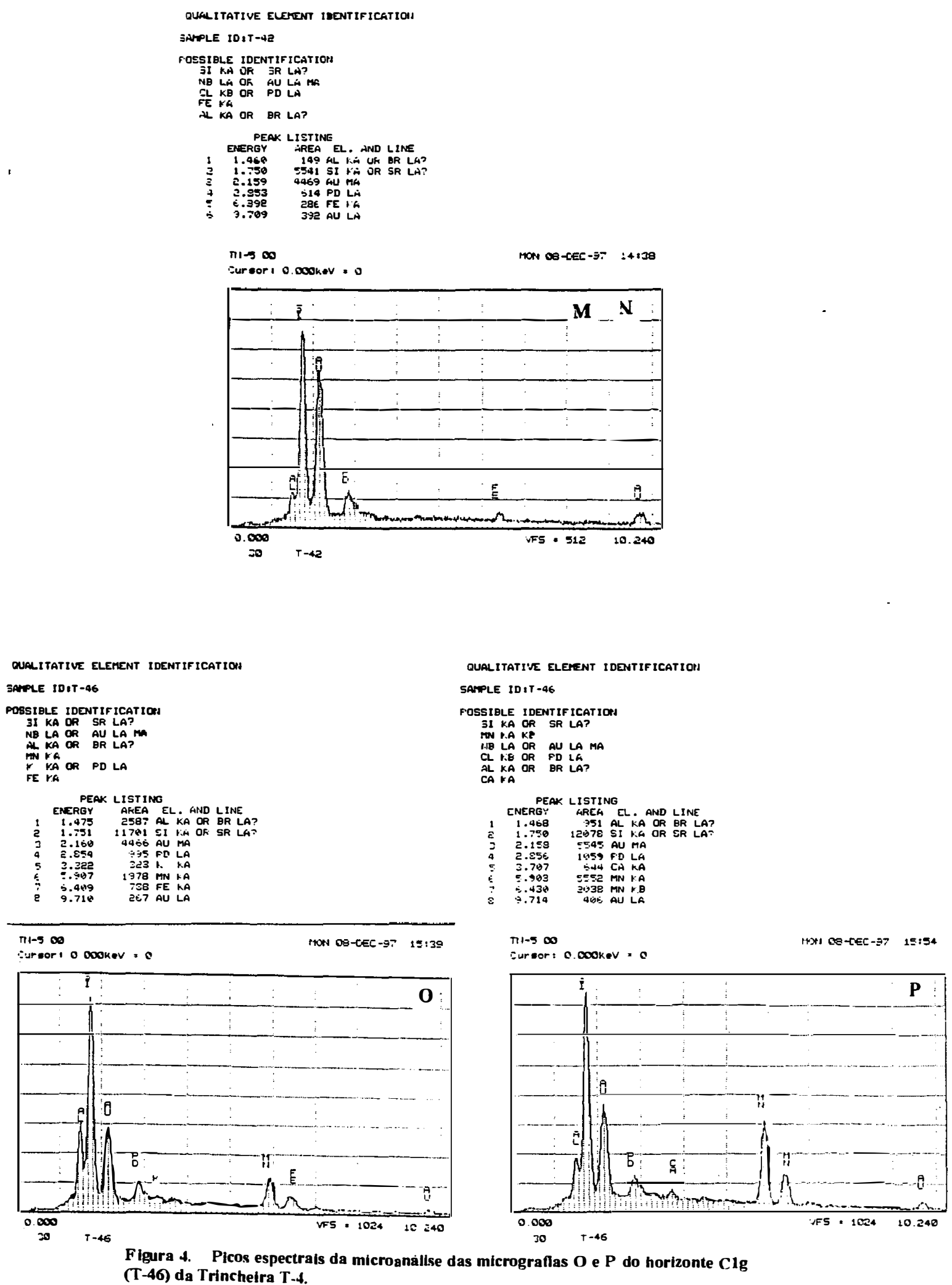

Figuras 4.18. Picos espectrais da microanálise (MEV) das micrografias $\mathrm{M}, \mathrm{N}, \mathrm{O}$ e $\mathrm{P}$. 
OULLITATIVE EDENT IUENTIFICATIOH

\section{SAMPLE IDITAS}

rOSSIBLE IDENTIFICATIOT

II $L A$ OR SR LA?

iL KA OR PD LA

PW VA

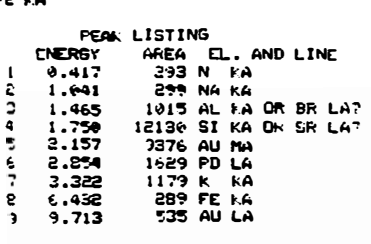

\section{$n 1-5 \infty$}

mi-5 $\infty$
Eureor: $0.000 \mathrm{hev}: 0$

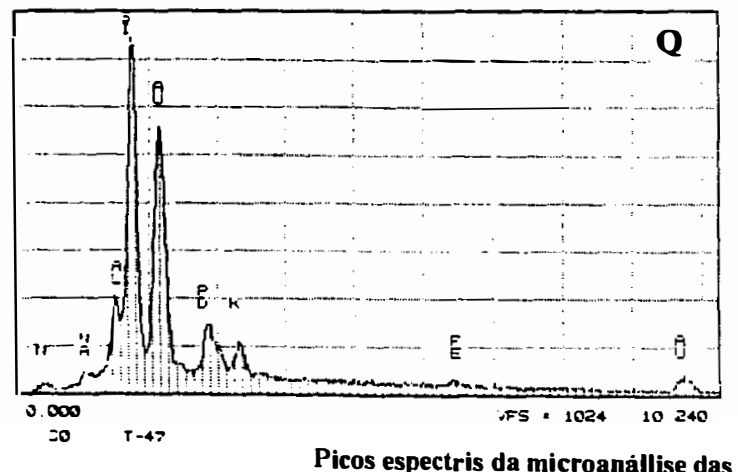

Picos espectris da microand 10240000 T-4., no límite C2 e lage de silex.
QUALITATIVE DEENT IDENTIFICATIOH

SAMPLE IDIT-46

POSE!GLE IDENTIFICATION

SIN KA KE KA OR SR LA:

PEAK LISTING ENEREY ARCA EL. AND LINE

$1.763 \quad 133 \mathrm{SI} \mathrm{KA}$ OA

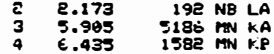

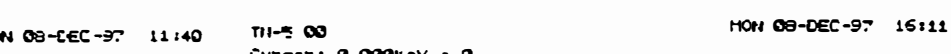

Surcor: 0.000kev : 0

$\mathbf{R}$

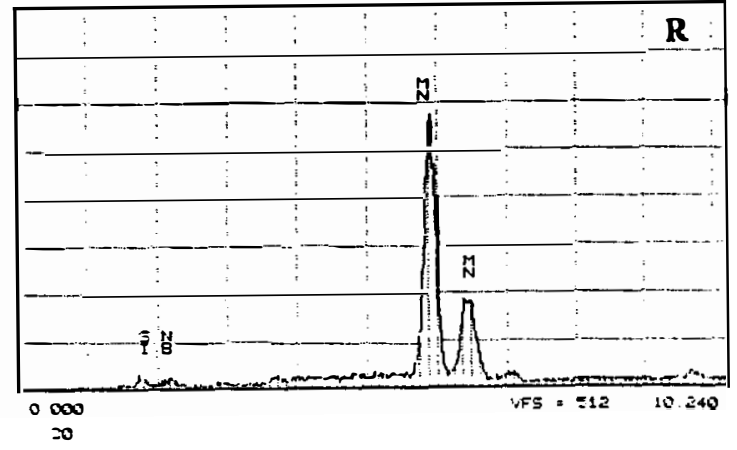

Figuras 4.18. Picos espectrais da microanálise (MEV) das micrografias Q e R. 


\subsection{ALTERAÇÃO DOS MINERAIS DA SEQÜÊNCIA ESTUDADA}

Um dos aspectos excepcionais dos solos tropicais é sua mineralogia. $\mathrm{O}$ intemperismo mineral é rápido e transforma os minerais primários, através de muitos estádios de reações, em muitas variedades de minerais secundários. $\mathrm{O}$ grau de alteração, de acordo com a fonte de material parental, neste caso argilitos e/ou folhelhos com matéria orgânica associados com calcário, tem grande influência na formação destes solos. Além disso, a posição topográfica que condiciona a drenagem e os fatores climáticos contribuem nos processos de intemperismo nesta região.

A presença do quartzo acelera grandemente os processos de podzolização nas zonas tropicais e temperadas (Tan \& Schuylenborgh, 1959; Estrada, 1971). Na zona de estudo foi constatado a abundância de bonecas de sílica que diminui em quantidade indo do perfil T1 ao T4, ou seja de drenagem boa à restrita. A figura 4.19 A mostra uma micro fotografia de boneca de sílica com fraturas transversais no início das quebraduras. Em outro estádio a Figura 4.19 B indica a presença de micro quartzo, muito abundante, ressaltando o seu papel nos processos de alteração.

Através da micro análise, observa-se nos horizontes (BC)1 e Rr do perfil T1 e na lage de silex entre 286 e $300 \mathrm{~cm}$ de profundidade, um arranjo submicroscópico composto de opala, que é uma forma de quartzo biogênico, constituido de grupos de esferas de sílica em empacotamentos tetraedrais. Cada pacote tem quatro esferas com um diâmetro de $2 \mu \mathrm{m}$ e cada esfera $1 \mu \mathrm{m}$ (Figuras $4.19 \mathrm{C}, \mathrm{D}$ ). Trabalhos similares indicam a presença das esferas empacotadas e sugerem a fórmula da opala como sendo $\mathrm{SiO}_{2} \mathrm{nH}_{2} \mathrm{O}$ utilizando o espectro infravermelho (Tan, 1996).

Há evidências de que a silica em solução formou-se em empacotamentos botrioidais variando de um tamanho de $58 \mu \mathrm{m}$ (Figura $4.19 \mathrm{E}$ ) a $80,5 \mu \mathrm{m}$, apresentando uma acentuada alteração para auxiliar na formação de um plasma cauliníticoesmectítico (Figuras 4.19 F). Outro fato é a formação de quartzo autigênico de forma piramidal- hexagonal e arranjados numa cristalização perfeita, em cristais de $1258 \mu \mathrm{m}$ de diâmetro, encontrados no horizonte C3 do perfil T1. Note o início da alteração iniciado pelas arestas (Figuras $4.19 \mathrm{G}, \mathrm{H}, \mathrm{I}$ ). 
Ao moer este quartzo e ser irradiado com raios $-\mathrm{x}$, as análises comprovaram a presença de $\alpha$ - quartzo, exibindo os picos de $0,33,0,24,0,22 \ldots 0,16 \mathrm{~nm}$, os mesmos que são visualizados na Figura 4.7.Tudo isso vem a confirmar o papel do quartzo na alteração dos materiais estudados.

A difração de raios- $\mathrm{X}$ das frações areia e silte assim como a microscopia eletrônica, indicaram que além do quartzo, outros minerais primários como os plagioclásios e ortoclásios, seriam as fontes de $\mathrm{Ca}, \mathrm{Na}$ e $\mathrm{K}$. Um feldspato calco- sódico do horizonte $\mathrm{C} 2$ do perfil T4, mostra uma formação de figuras de dissolução em um plasma esmectítico (Figura $4.19 \mathrm{~J}$ ). Pela sua vez, a mica encontrada neste mesmo horizonte está alterando-se em esmectita (Figura $4.19 \mathrm{~K}$ ). Micrografias similares atribuídas à biotita foram encotradas por muitos autores (Hill \& Sawhney, 1969; Shoba \& Sokolova, 1981; Robert \& Tessier, 1992; Modenesi- Gauttieri \& Toledo de M, 1996), mas Tan (1996, p.315), indica que este tipo de mica, com o primeiro pico de difração de $0.101 \mu \mathrm{m}$ pertence à ilita. Portanto, devido a essa premissa, além do espectro da microanálise (Figura $4.20 \mathrm{~K}$ ) destacar mica com um considerável valor de $\mathrm{K}$, pode-se tratar de ilita, mas não de biotita. Além disso, a micro análise da Figura $4.19 \mathrm{~L}$, detalha outras fontes primárias de $\mathrm{Ca}$ e de $\mathrm{Mg}$ que poderia ser devidas à presença de dolomitos e/ou folhelhos da FI. Note a presença destes cátions além do K, Ti e Fe numa matriz esmectítica evidente ao comparar as relações $\mathrm{Si} / \mathrm{Al}$ nesta micro análise(Figura $4.20 \mathrm{~L}$ ).

Os minerais secundários acessórios tais como a hematita, goethita estariam acompanhando as alterações termodinamicas nestas soluções. A Figura 4.19 M, cujo espectro é dominado pelo $\mathrm{Fe}$ (Figura $4.20 \mathrm{M}$ ), sugere a existência da goethita, como foi salientado pelos pesquisadores Robert \& Tessier (1992) e comprovado através de raios-X (Figura Apêndice $3 \mathrm{~A}$ ). A fração de tamanho argila é dominada pela caulinita com maior intensidade nos horizontes dos perfis de boa drenagem (T1) e os horizontes superficiais do T2. Tal mineral tende a diminuir com o aumento do hidromorfismo e se manifestar os argilominerais 2:1, tipo esmectita (nontronita) e outros minerais interestratificados (Figuras 4.9 até 4.15).

Nota-se que a medida que se dirige dos horizontes da superficie até a lage de sílex e em direção do T1 ao T4, a caulinita tende a alterar seus picos. Assim, na 
Figura 4.11, observa-se no horizonte (BC)1 do perfil T1 o pico da caulinita é de 0.72 e $0.36 \mathrm{~nm}$; no (BC) 1 do perfil T2 diminui para $0.70 \mathrm{~nm}$ e 0.35 ; no Btgv2 do perfil T3 e $\mathrm{Clg}$ do T4 fica em 0.68 e $0.34 \mathrm{~nm}$. Note-se que há uma evidência de de alteração na sua estrutura e os picos mal formados são também indicados na micrografia do MEV na Figura 4.19. $\mathrm{N}$ que mostra cristais ligeiramente hexagonais da caulinita com $0,1 \mu \mathrm{m}$ de comprimento e $0.08 \mu \mathrm{m}$ de largura. Ducloux et al.(1998) notaram através de micrografias de frações menores que $0.1 \mu \mathrm{m}$ a haloysita junto com partículas de beidelita em solos aluviais de Nigéria.

Em forma similar os picos de $0.74 \mu \mathrm{m}$, ligeiramente superiores ao de caulinita da Figura 4.12 e que desaparecem ao aquecer o material a $\mathrm{K}-500^{\circ} \mathrm{C}$, fazem suspeitar da presença de haloysita que é acompanhada pela caulinita na micrografia anterior. A haloysita ficou confirmada através da MEV exibindo tubos enrolados de 0.38 $\mu \mathrm{m}$ de comprimento e 0,08 de largura (Figura 4.19. N). FitzPatrick (1983) encontrou tubos de $1 \times 0.1 \mu \mathrm{m}$ de tamanho similares aos encontradas neste trabalho.

A presença de feldspatos e micas no material de origem podem gerar argilominerais 1:1, 2:1 e interestratificados como comprovados pelos raios- $X$ e microscopia eletrônica. As micrografias da Figura 4.19 mostram os argilominerais 2:1, tipo esmectita, nas seguintes condições:

a). No Btgv2 do perfil T4 as micrografias da Figura 4.19 O, P, ilustram partículas de esmectita de $2,75 \mu \mathrm{m}$ de diâmetro. Quando aumentado a 7,500 vezes permite observar sua estrutura que é composta por camadas concêntricas envoltas em uma matriz ferruginosa. Tal matriz possivelmente seja o local onde o ferro foi substituido pelo alumínio na camada octaedral.

Estes esferoides podem ser formados nos micro poros dos fragmentos da silica intemperizada. Esferoides de esmectita com um diâmetro na faixa de 2 a $3 \mu \mathrm{m}$ foram encontrados mediante análise pela MEV na bentonita de Wyoming (montmorilonita), desenvolvidos em micro poros de fragmentos de andesita intemperizada (Borchardt,1989 p.680). Recentemente Jongmans et al.(1998), 
salientaram que em condições de drenagem restrita os poros vesiculares, são locais de estagnação temporária de soluções rica em $\mathrm{Si}$ e consequentemente, favorecendo a formação da esmectita.

Tais autores encontraram nas superficies rugosas esferoides de esmectita neoformada. As microfotografias 4.19. Q, $\mathrm{R}$, indicam que o horizonte Btgv2 do T4 apresenta um plasma formado principalmente por esmectitas e que sofreu micro rachaduras formando um padrão típico designado de "honeycomb" ou "favo de mel", recobertos por óxidos de ferro. Trabalhos similares constataram o padrão de "honeycomb" como sendo material 2:1, expansivo (Mermut et al.,1985; Robert \& Tessier,1992; Jongmans et al.,1998).

b). No horizonte E do perfil T4 (Figura $4.19 \mathrm{~S}$ ), foram encontrados materiais reliquiais de plasma esmectítico com padrão de "honeycomb" em processo de alteração, sendo uma evidência da destruição das argilas devido à ferrólise (Brinkmann,1970). Nas microanálises sempre está presente o ferro e também o Mn. Tais constituintes contribuem para a formação de padrões de honeycomb. $\mathrm{O} \mathrm{Mn}$ é liberado no processo de alteração dos cristais de manganita como se observa na micrografia da Figura 4.19. T. Nesta micrografia nota-se o plasma de esmectita envolvendo os cristais de manganita com ramificações semelhantes ao formato da palma de uma mão. As micrografias da Figura 4.19. T, U, esclarecem tais microformas com a microanálise respectivo.

Em relação a pirita encontrada nas concreções de silica nos horizontes de transição permite as seguintes observações:

a). Presença de grãos simples e agrupados em forma de "clusters" principalmente no centro das concreções, (Figura 4.19.V) .

b). Tem sido notado a ocorrência d pirita framboidal no horizonte Ap do perfil Tl (Figuras $4.17 \mathrm{~A}$ ). Pirita com cristais cúbicos eudrais com seções retangulares em processo de alteração (Figuras $4.19 \mathrm{~V}$.), onde um "cluster" de pirita está se alterando (note-se a presença da hematita).

Portanto, é possível sugerir que parte do Fe destes solos é originário da pirita, que ao ser afetada pelo hidromorfismo o ferro é reduzido e pode-se transformar 
em ferrihidrita precursor da hematita em condições de oxigenação; ou em goethita quando a drenagem é restrita. Os difratogramas das amostras contendo ferro (Figura apêndice $3 \mathrm{~A}$ ),indicam a presença de hematita no $\mathrm{Tl}$ e goethita no $\mathrm{T} 4$. 
Figuras 4.19.

Fotomicrografias (seção delgada) e micrografias (MEV) da alteração dos minerais na seqüência de $\mathrm{A}$ até $\mathrm{V}$. 


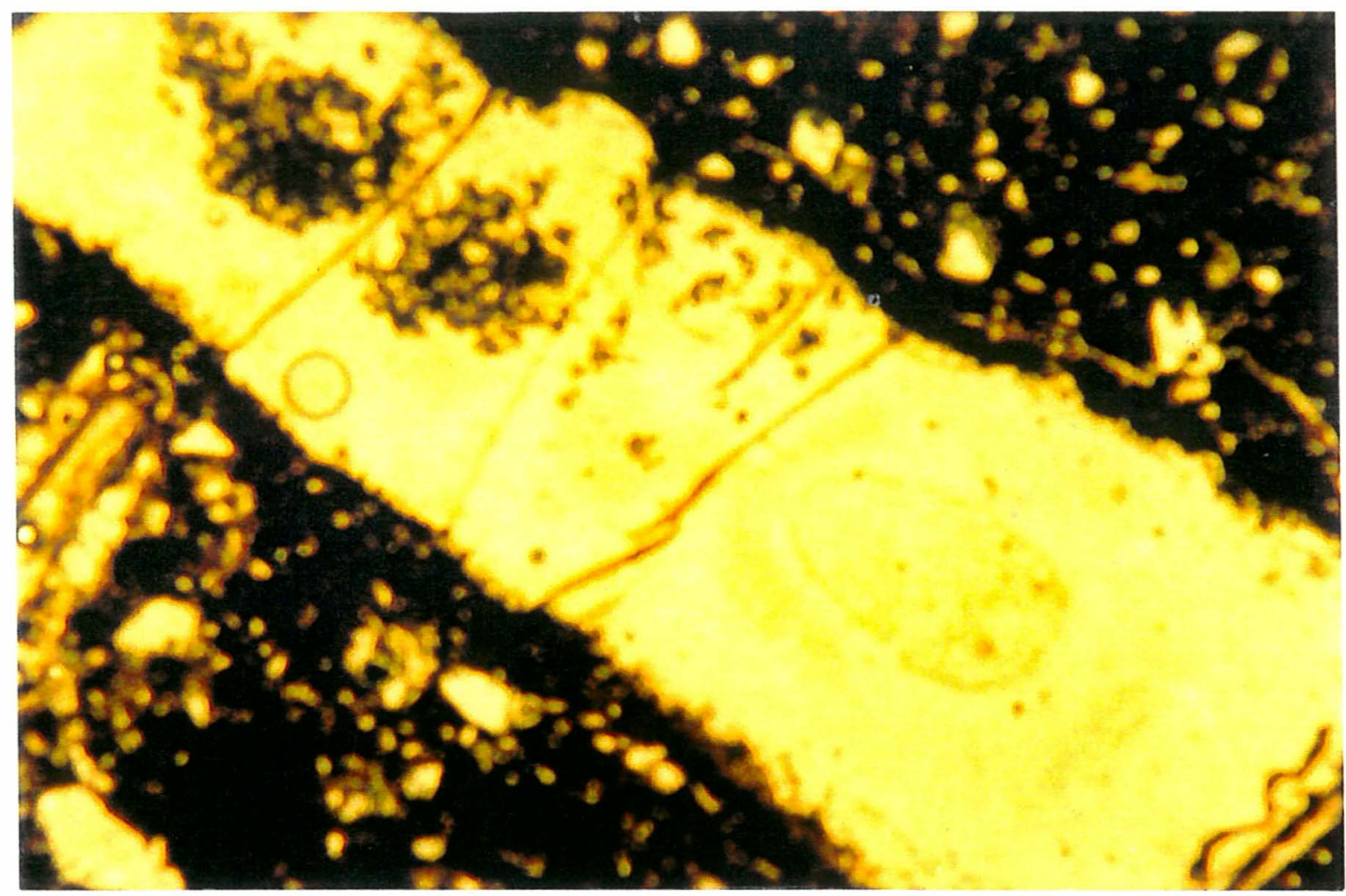

Figura 4.19(A). Fotomicrografia de uma boneca de sílica com fraturas transversais do horizonte Ap do T1.

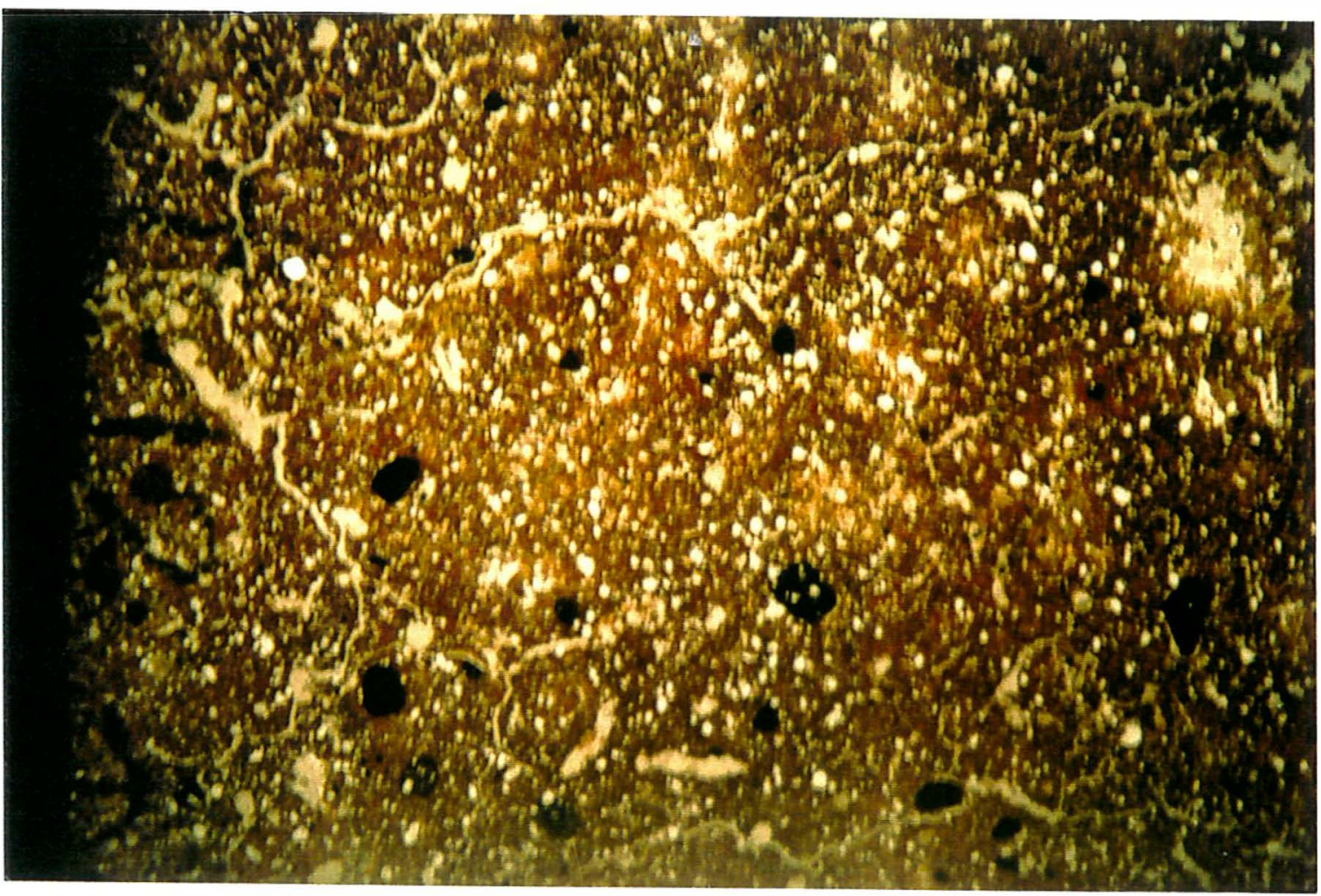

4.19.(B) Fotomicrografia do Btl do perfil $\mathrm{T} 1$ com estrutura de base isótica, com microquartzo e maior porosidade fissural que o Ap. 


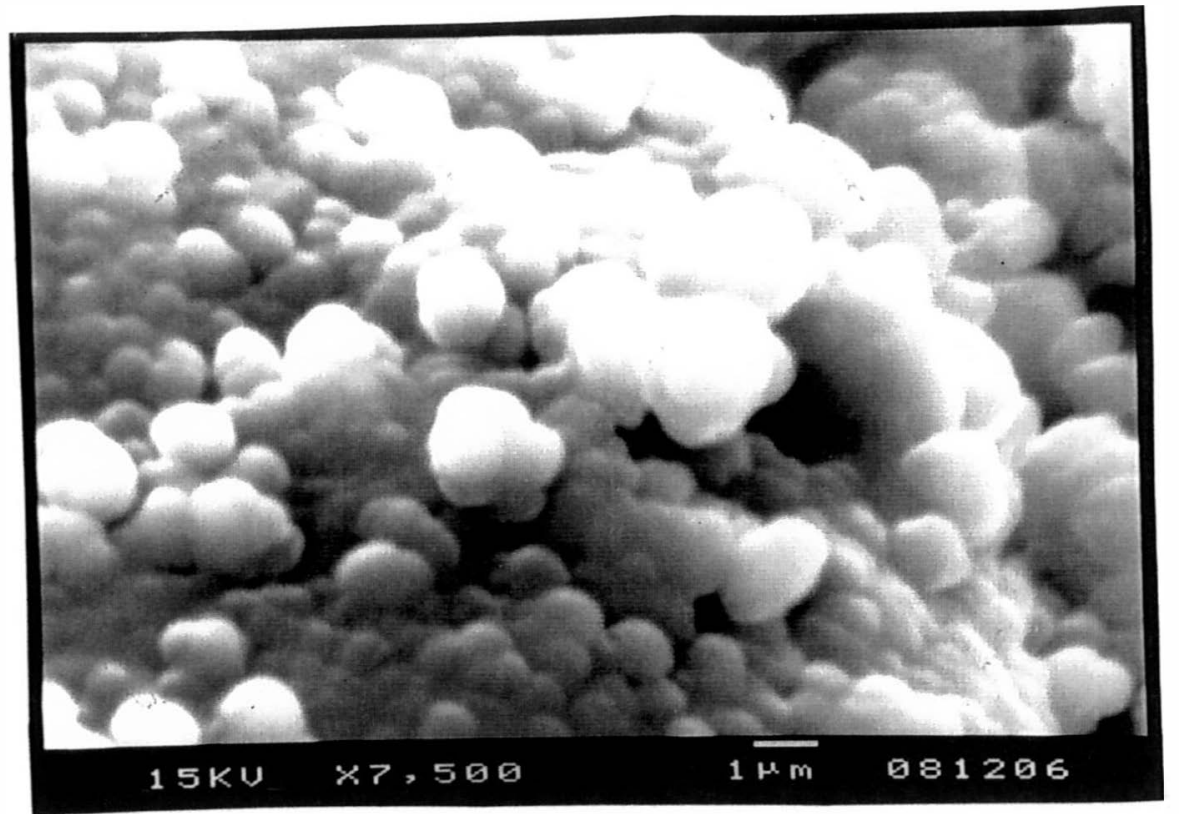

Figura 4.19(C) Micrografia dos horizontes (BC)I e Rr do perfil Tl arranjo submicroscópico de opala com esferas de sílica empacotadas.

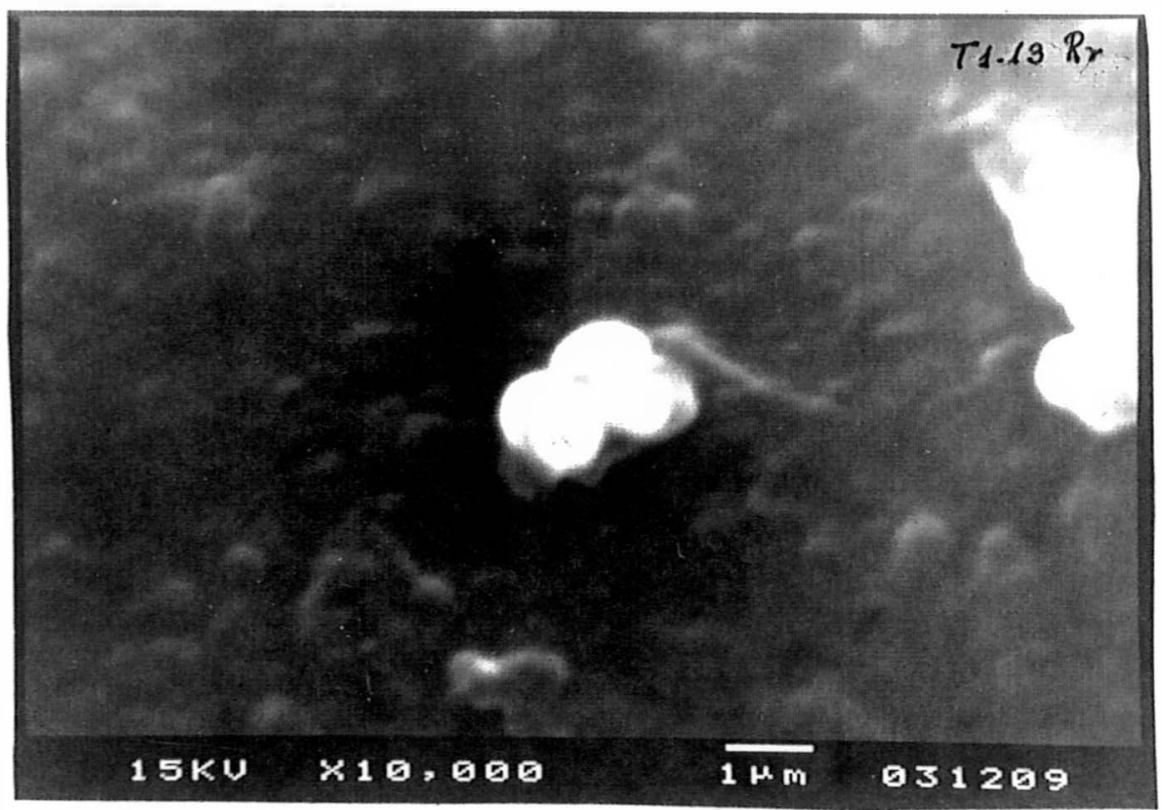

Figura 4.19. Micrografia de um pacote de 4 esferas de sílica com um diâmetro de $2 \mu m$ e cada esfera $1 \mu$ m com aumento de 10,000x. 

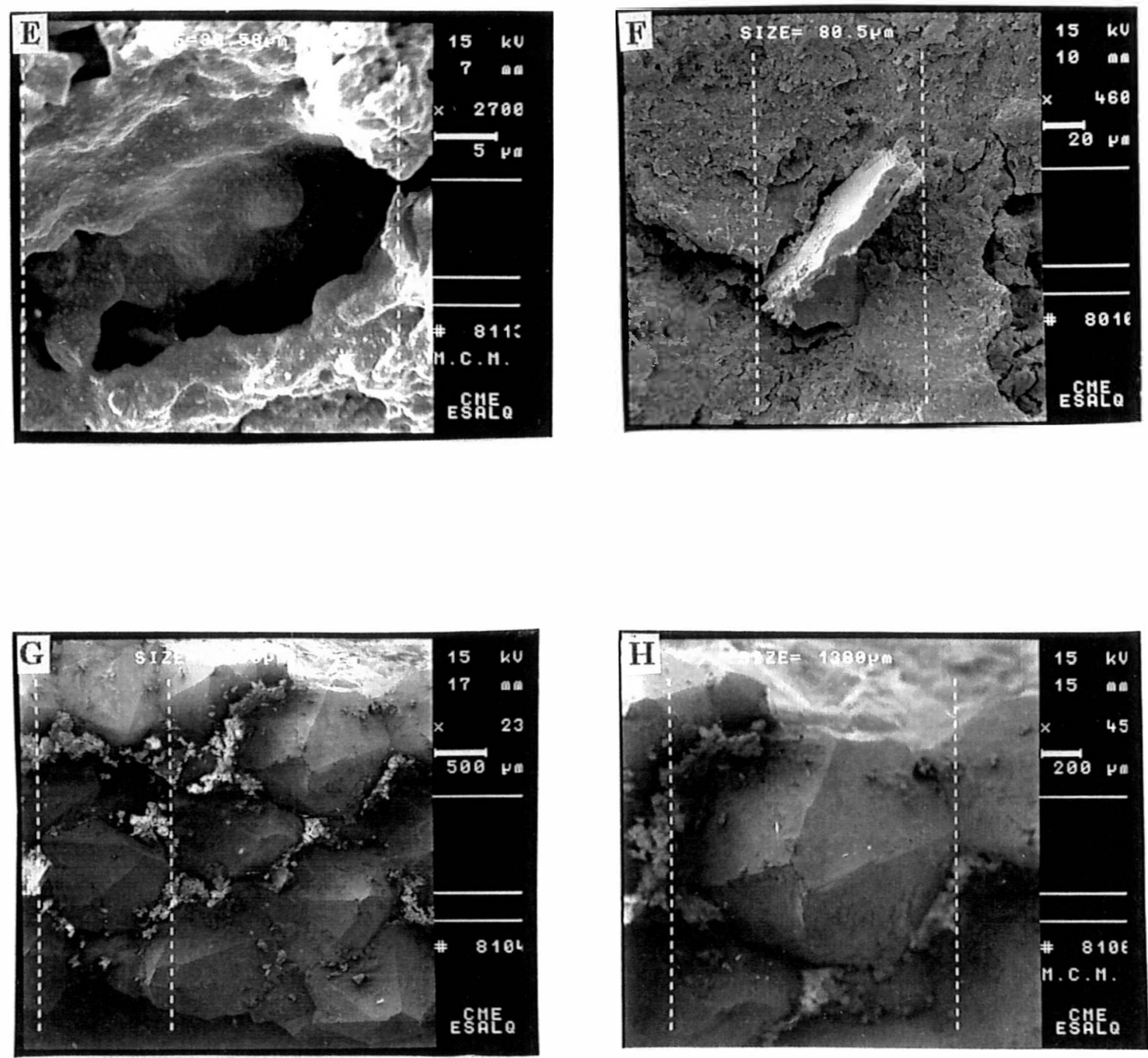

lïgura 4.19. (E) Empacotamento botrioidal de sílica de $58 \mu m$ de tamanho no horizonte $\mathrm{C} 3$ do perfil T1; (F) Microgratia do fiagamento de sílica de $80,54 m$ alterando-se num plasma caulinílico-esmectitico; (G), (H) Quartzo autigênico com cristais de 1,258нum de diâmetro no horizonte C 3 perfil Tl. 

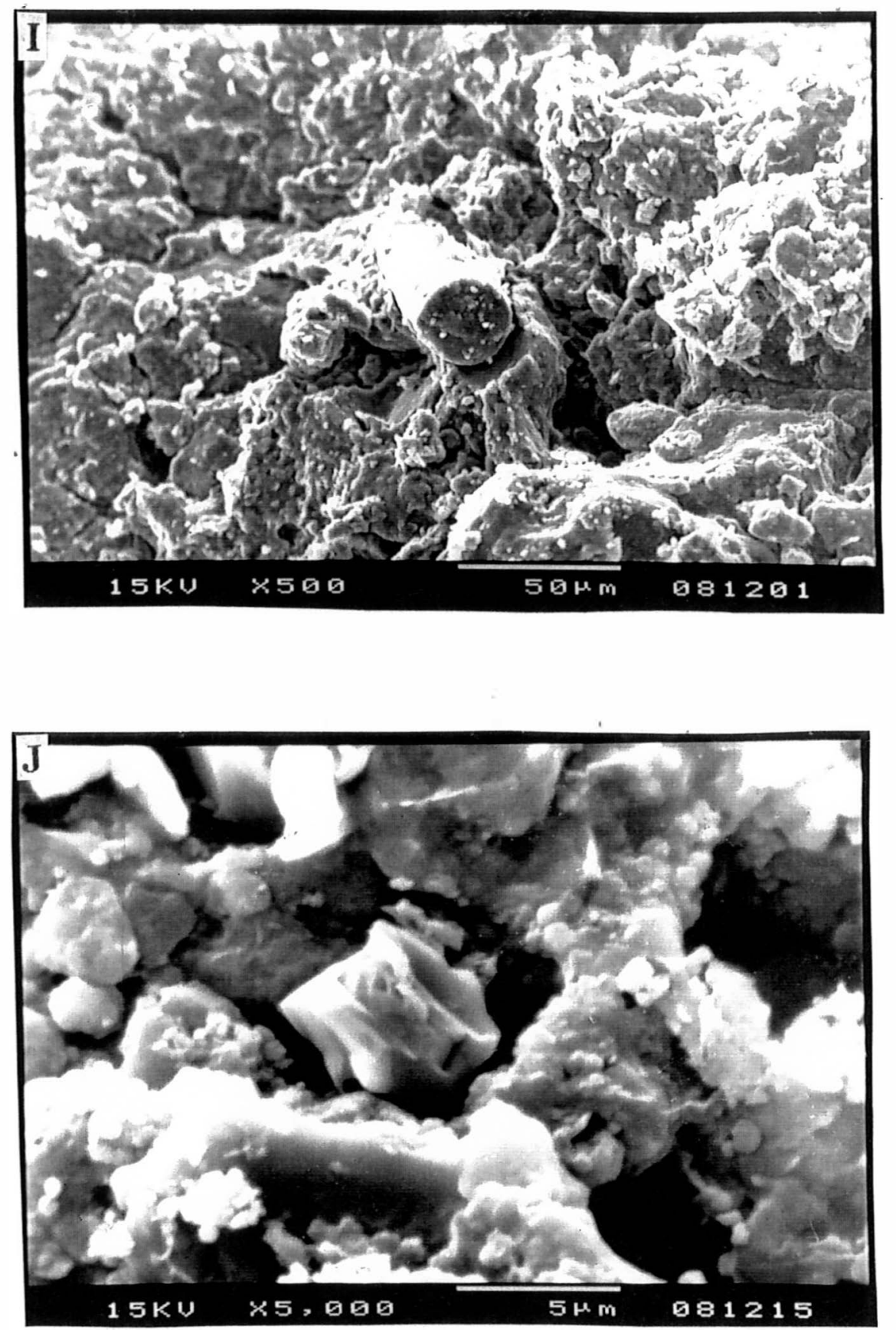

Figura 4.19. Micrografias (MEV) (I) Fragmento de sílica intemperizando-se num plasma caulinítico-esmectitico no (BC) I do perfil Tl; (J) Figura de dissolução de um feldspato calco-sódico em um plasima esmectítico no $\mathrm{C} 2$ do perfil T4. 

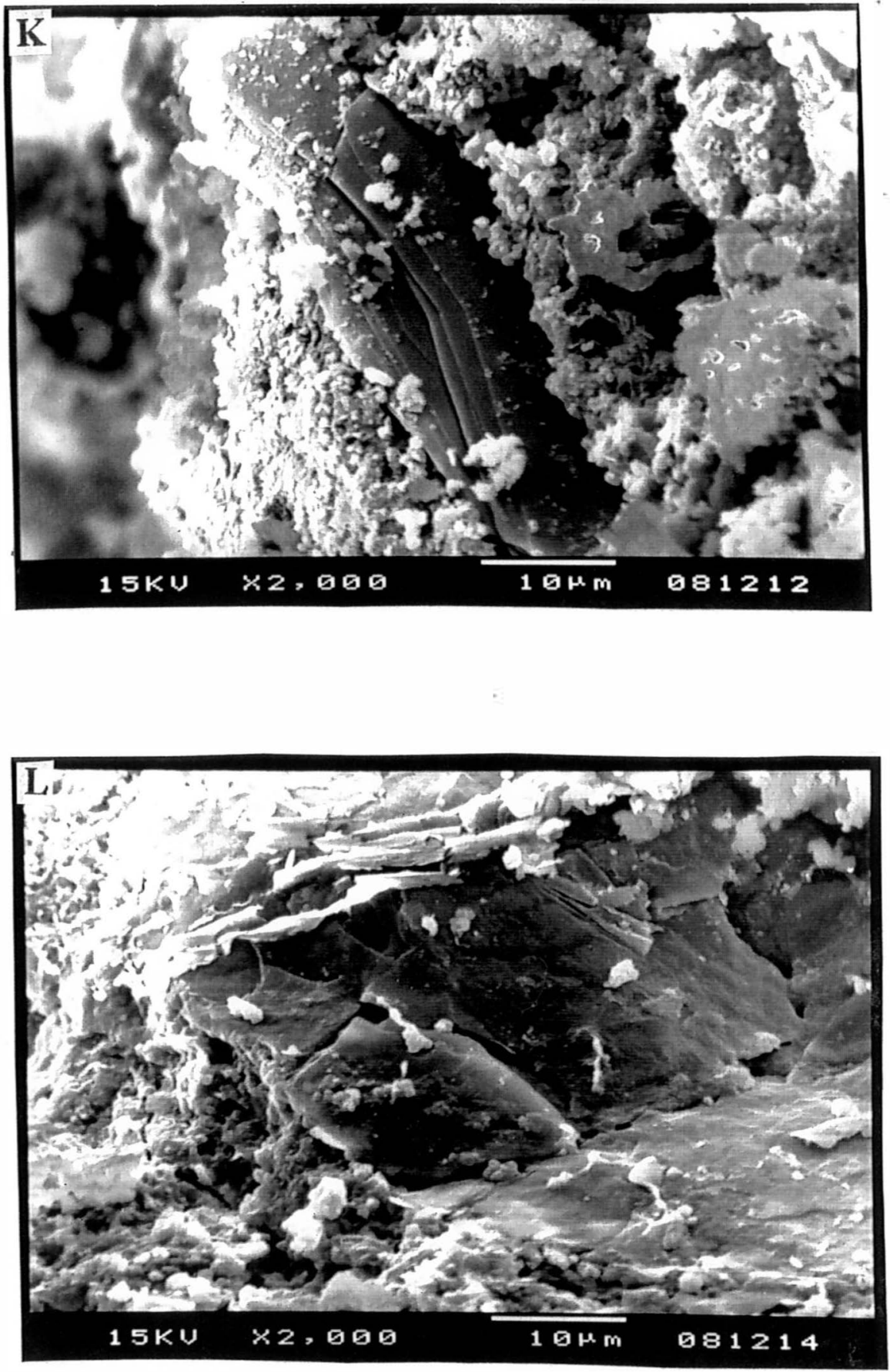

Figura 4.19. Microgratias (MEV). (K) Mica alterando-se em esmectita no C2 to T4; (L) Fragmento de dolomito e/ou folleello numa matriz esmectitica no mesmo horizonte. 


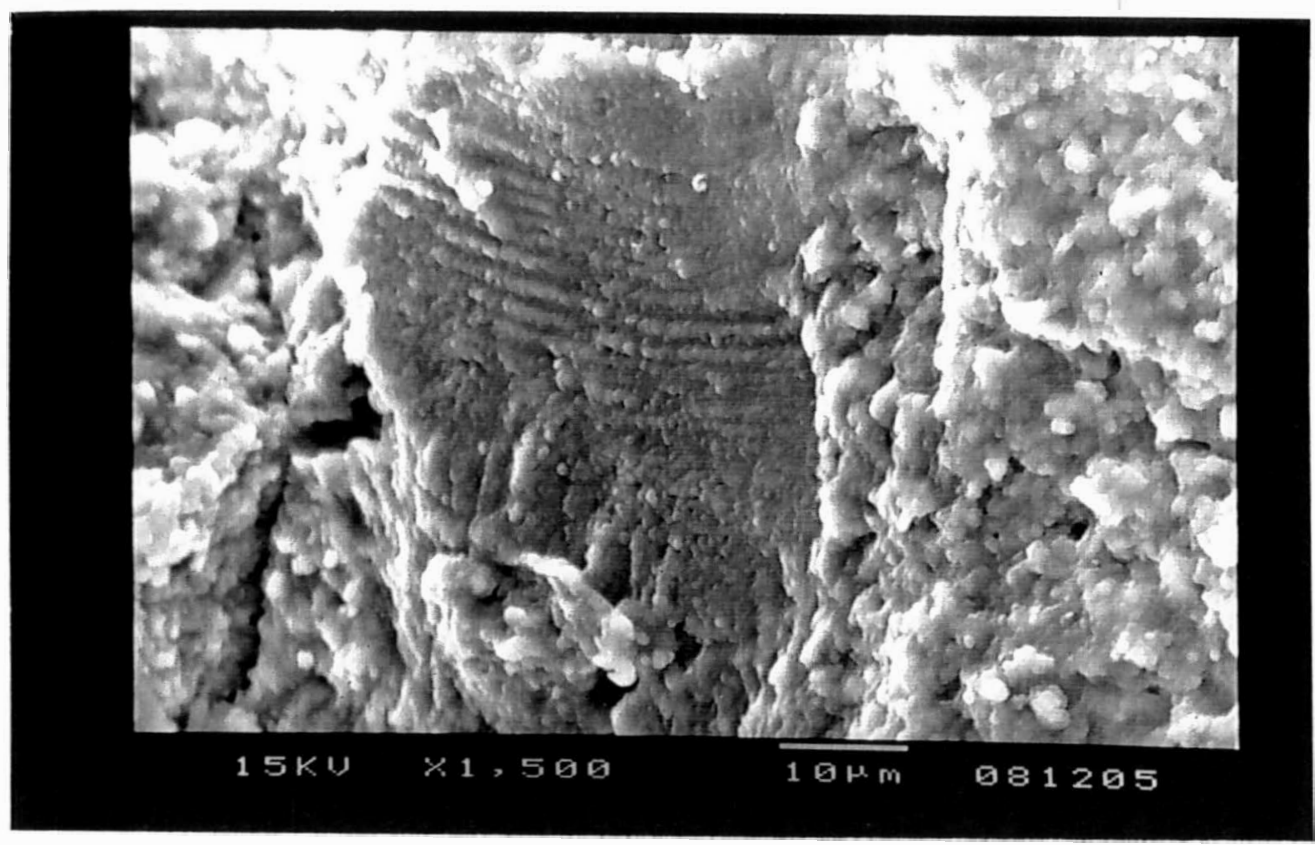

Figura 4.19. Micrografia (MEV). (M) Goethita no horizonte (BC) I do perfil TI. 

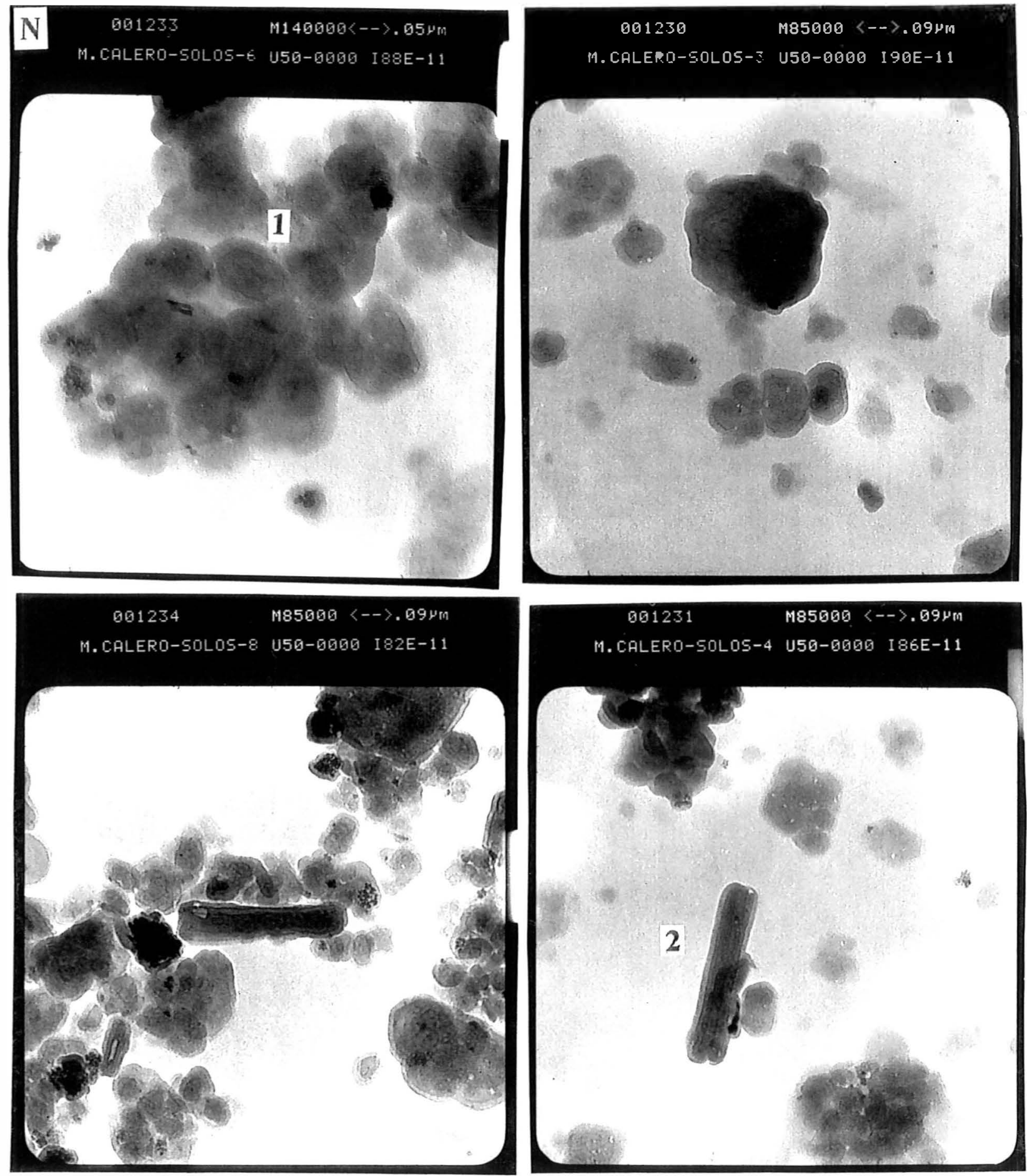

liggua 4.19. Microgratias (MET). (N) Cristais ligeiramente hexagonais de caulinita (I) e lubos enroladios de haloysila (2) no horizonte Bul do perlil 'Tl. 

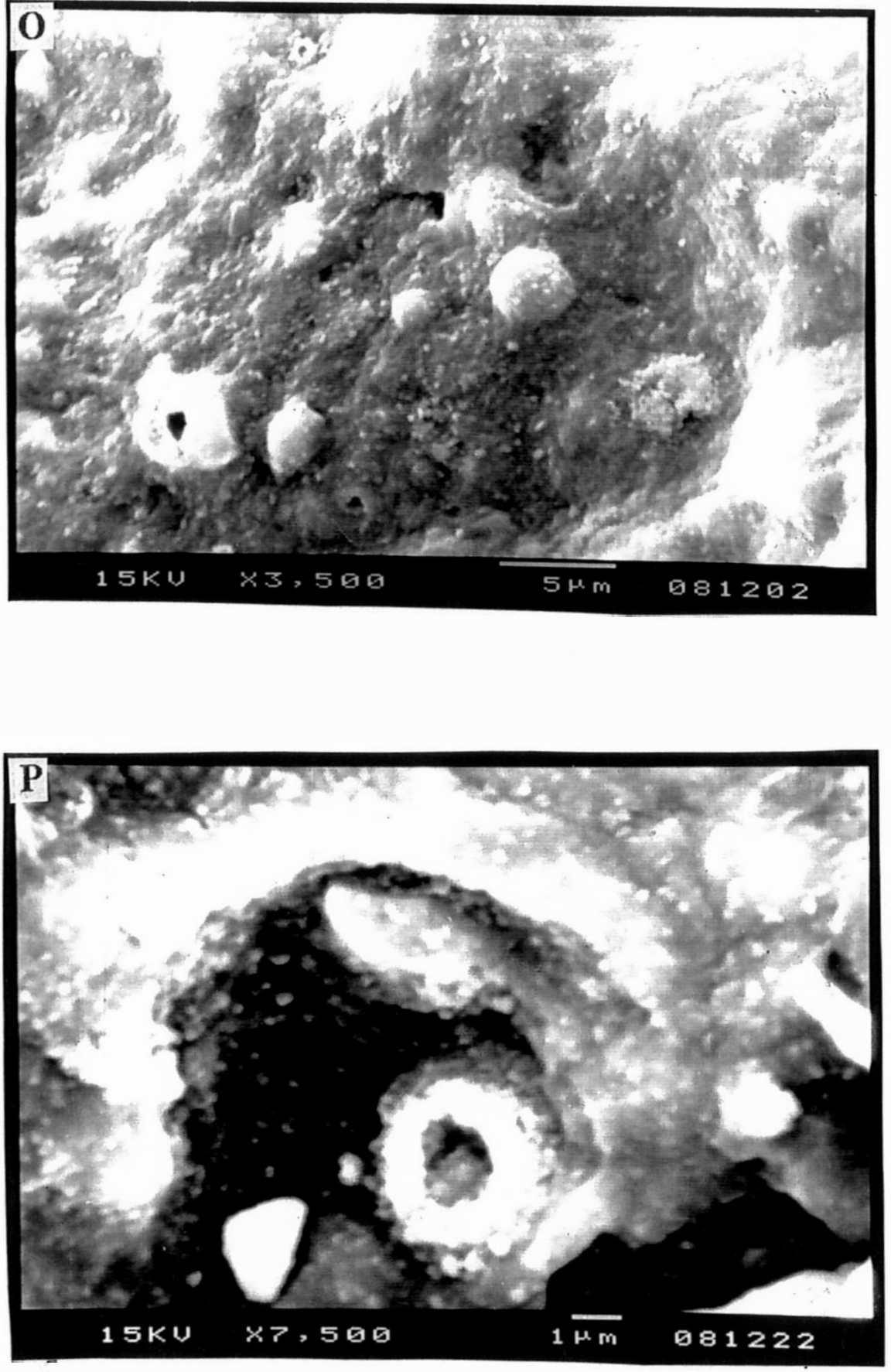

Piguras 4.19. Micrografias (MEV). (O) Esferoides de esmectita do horizonte Btgv2 do perfil T4; (P) Esferoide aumentado 7,500x com camadas concêntricas em uma matriz ferruginosa. 

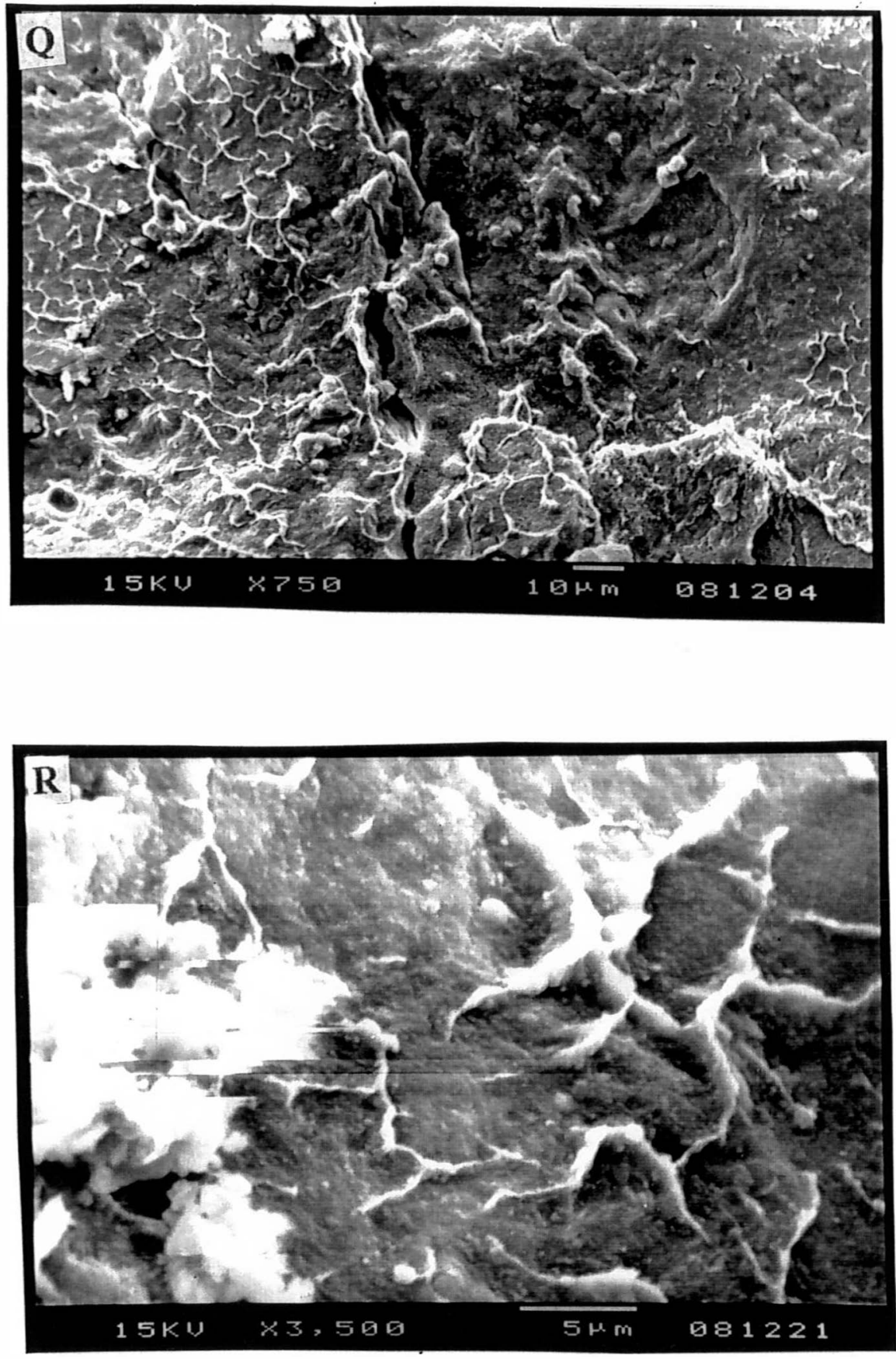

Figura 4.19. Micrografias (MEV). (Q) Plasma esmectítico com microrachaduras exibindo um padrão de "honeycomb" no Btgv2 do T4; (R) O padrão aumentado 3,500x. 

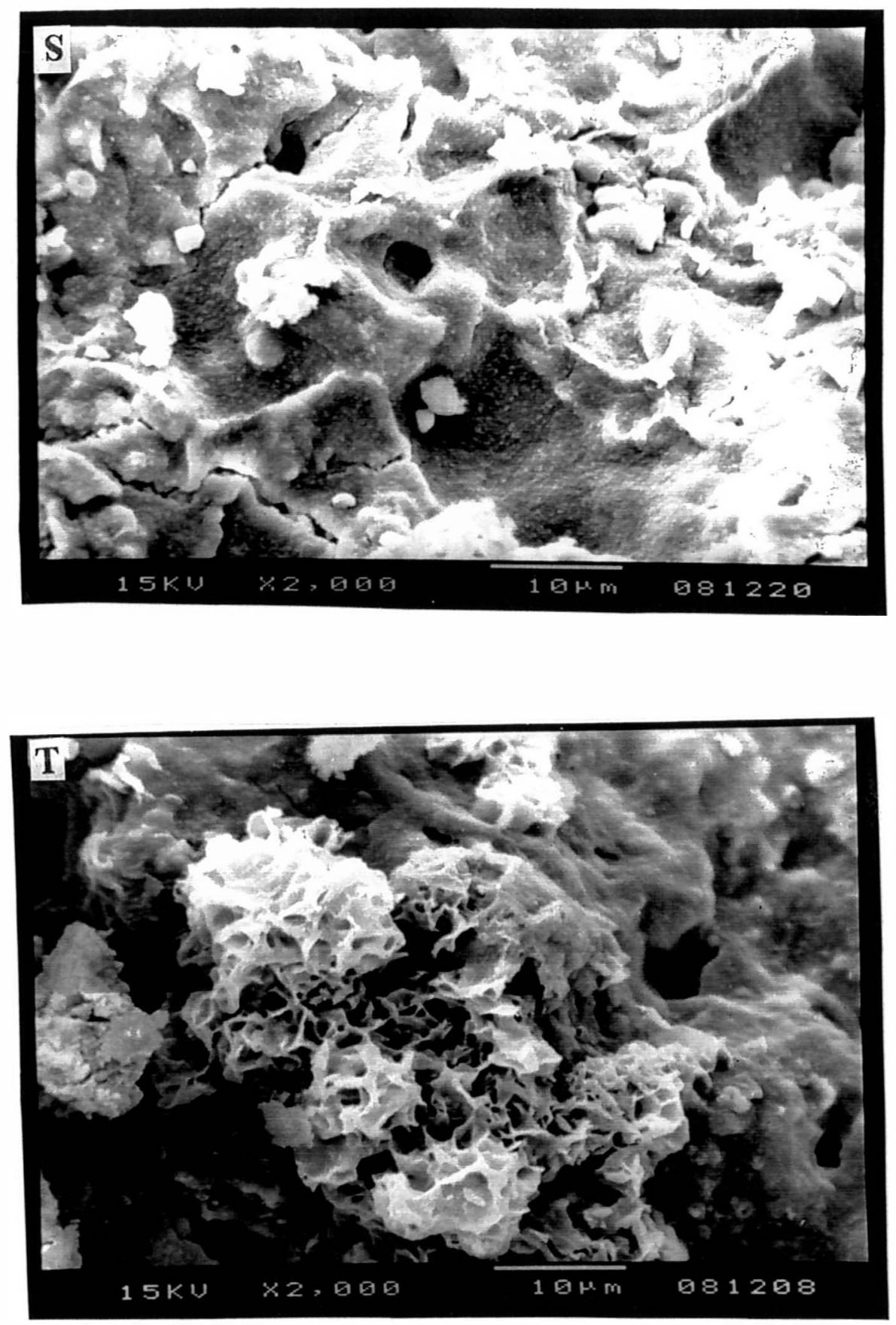

Figura 4.19. Micrografias (MEV). (S) Materiais reliquiais de plasma esmectitico, cujo padrão "honeycomb" está alterando-se devido à ferrólise no E do T4; (T) Cristais de manganita contribuem à formar o padrão de "honeycomb". Observe o plasma de esmectita semelhante a palma da mão. 


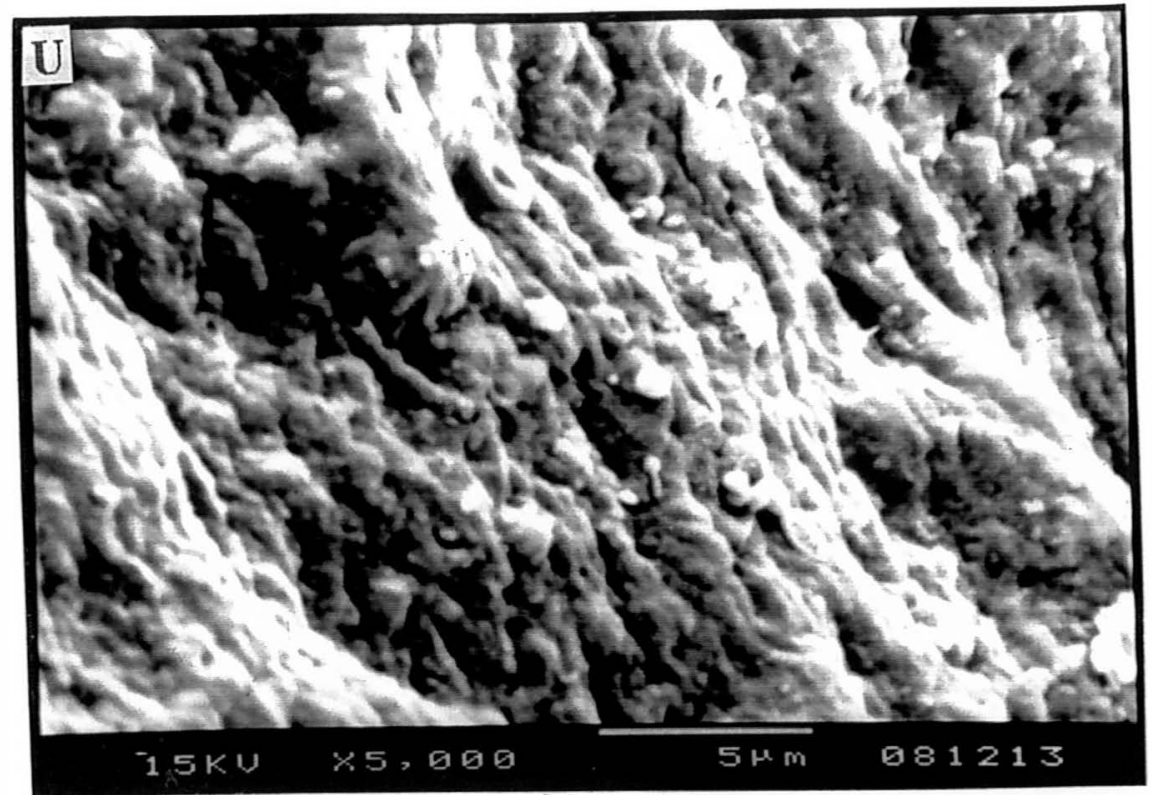

QUAL ITATIVE ELEMEINT IDENTIFICATIOH

SAMFLE ID: T-47

POSSIBLE IDENT IF ICATION

3I KA OF: NE LA OFi AU LA MA \&. ESCAFE PEAK

SI KA OF SF LA?

CL KB OF: FD LA

AL KA UR: ER: LA?
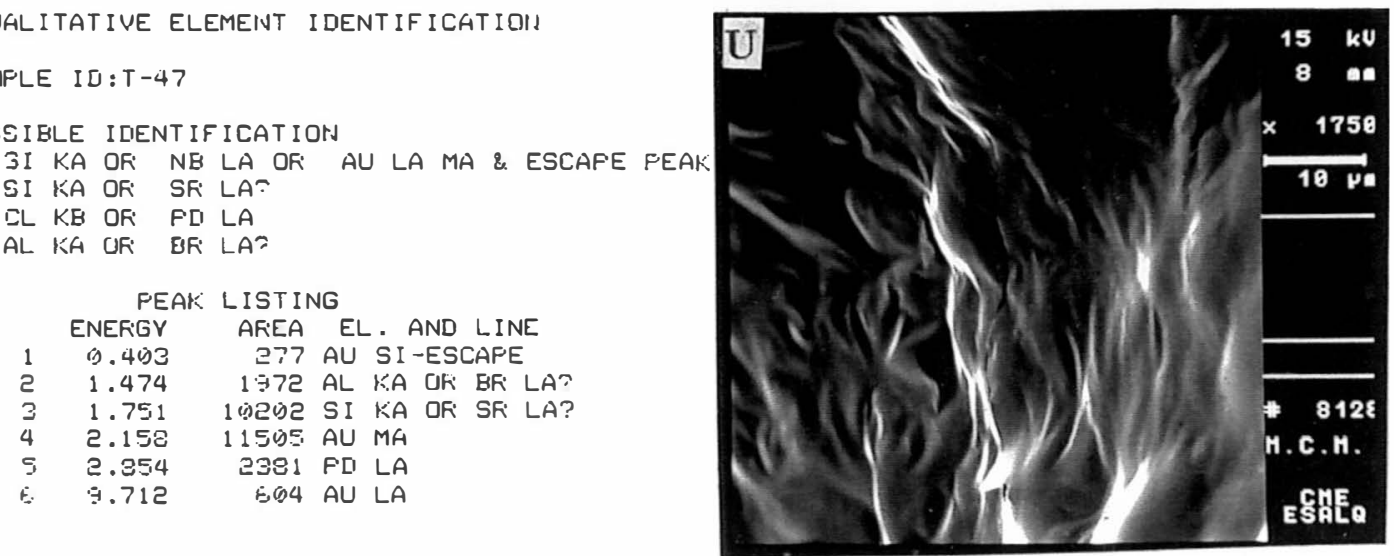

TI1-S DO

MMN O8-DEC-9? 12:05

Cursor: $0.000 \mathrm{k} 2 \mathrm{~V}=0$

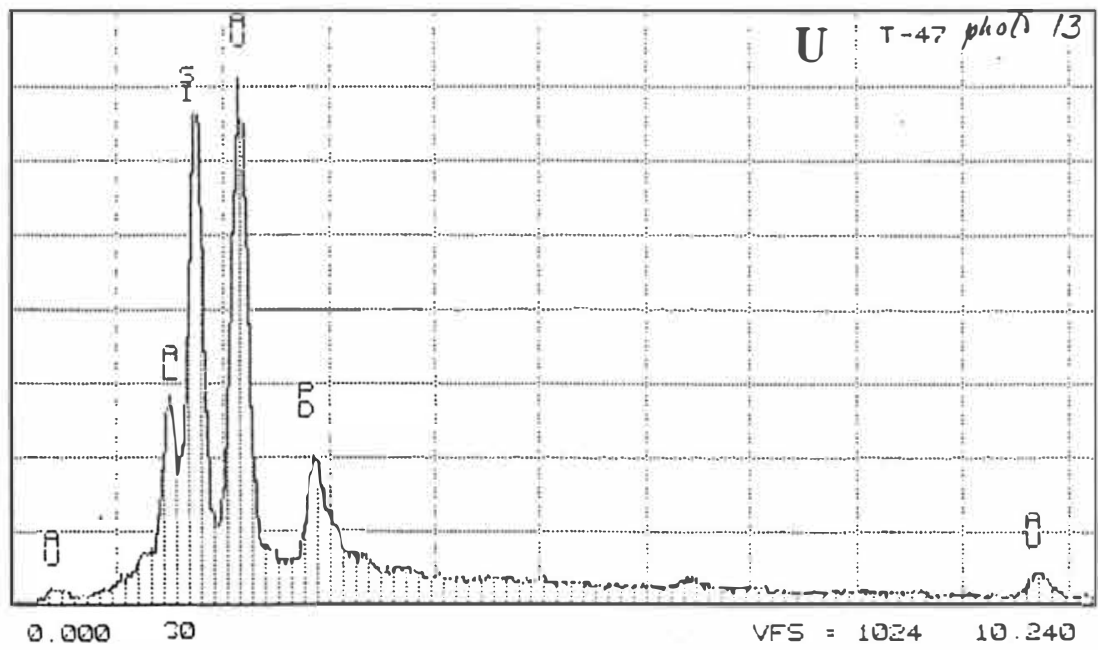

Figura 4.19. Microgralias (MEV). (U) Plasma esmectítico com ramificaçõẹs semelhantes ao formato da palma de uma mão, $5 \mu$ m e 5,000x; com o seu microanálise. 


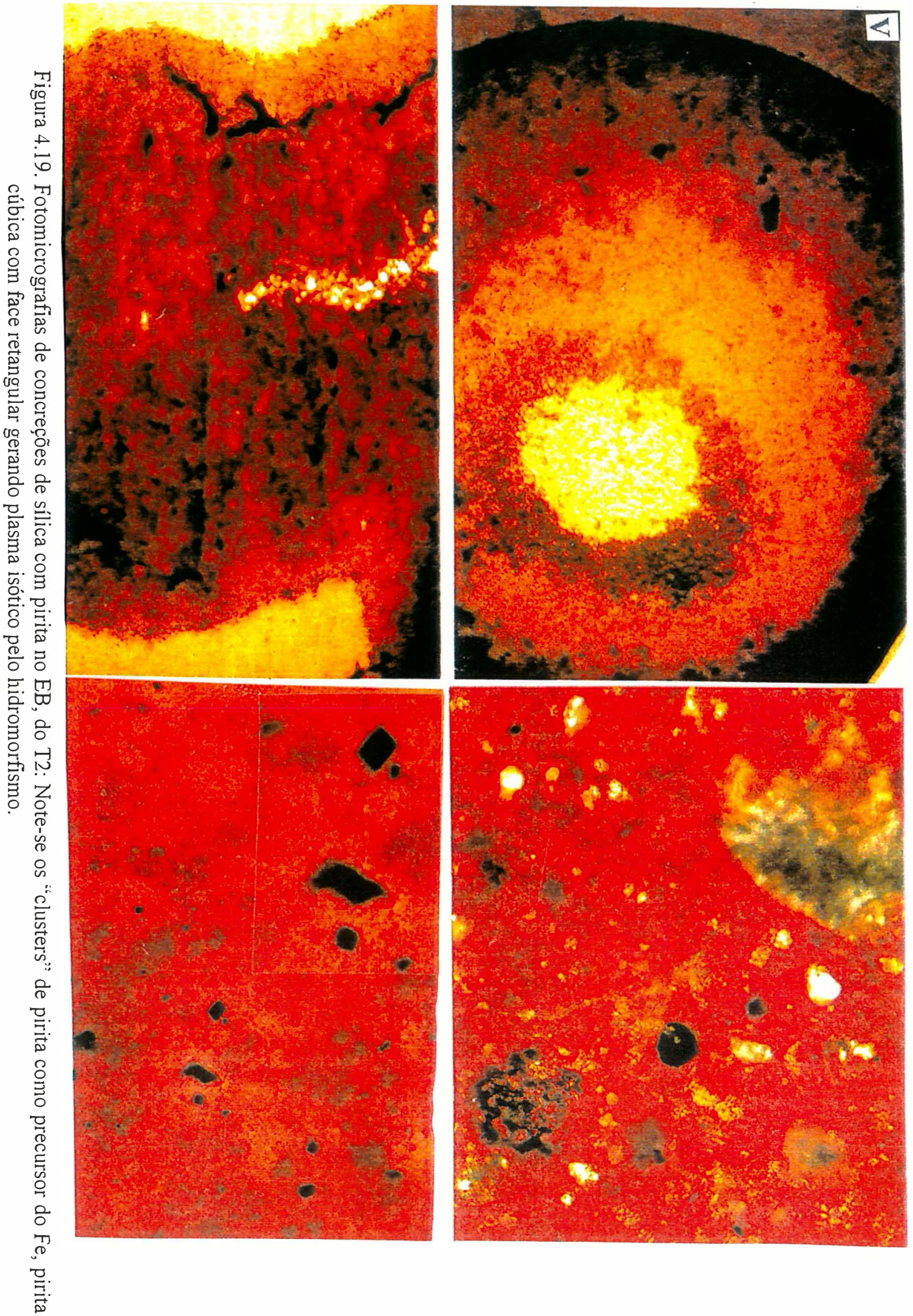


Figuras 4.20.

Picos espectrais das micrografias das Figuras 4.19. I na seqüência I até T. 
IIN FLEXTRAN (13-E)

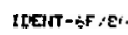

SURITATIVE ELEMENT IDERTIFICATIJN

SWTLE IDIT-1S

POSSIBLE IOENTIFILATION

SI IA OK SF LA?

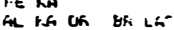

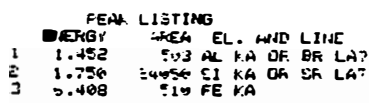

$\pi 1-\infty$

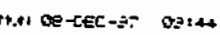

iureori a corer $=0$

I

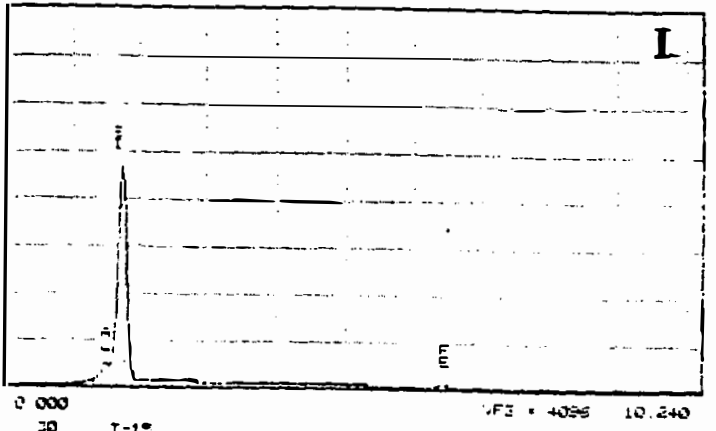

QUALITATIVE ELEET IDENTIFICATIOI

\section{SAMPE 10:T-4?}

FOSSIBLE IDENTIFICATIOS

SI KA OR SR LA?

NR LA OR AU LA

K KA OR IN LA:

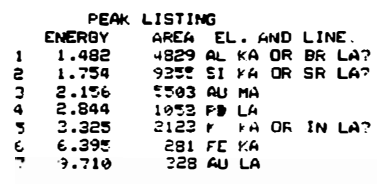

$\pi 1-5 \infty$

Eursori o cookev = 0

InN1 08-LEC-97 11:ES

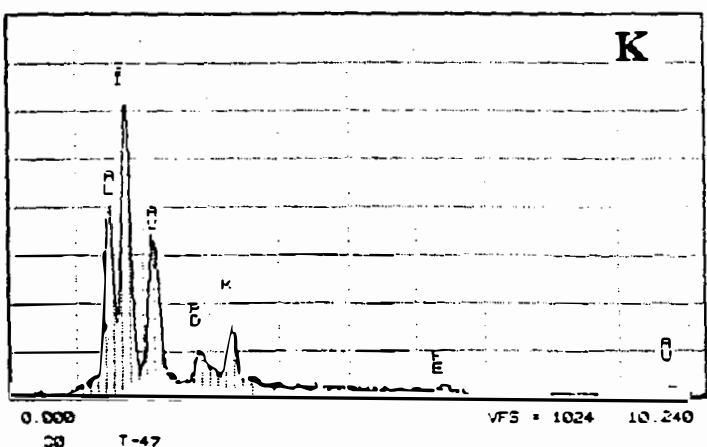

QUALITATIVE QERENT IOENTIFICATIOH

jAPPLE ID:T-4?

POSSIBLE IDENTIFICATION

SI KA OR SR LAP

NB LA OR ONR LA MA
OL KA OR BR LA?
CL KR FD LA

NAA $K A$

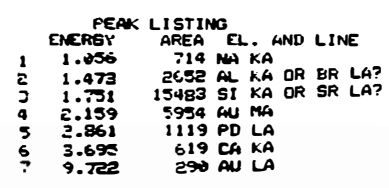

nis $\infty$

HAN De-tec-97 12:20 ureor: 0.000kov = 0

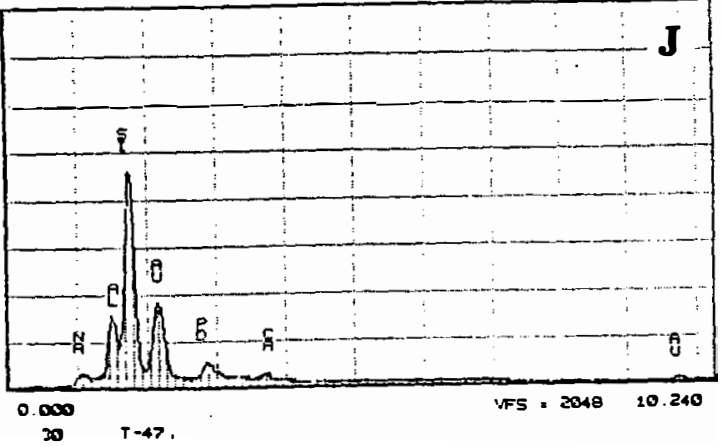

QUALITATIVE ELEMENT IDENTIFICATIOA

SNPE $10, T-47$

FOSSIBLE IDONTIFICATIOR

II K.A OR SR LA?

NE LA KR AU LA

AL KA OR BR LAT

CL $1 . B$ OF FO LA

TI

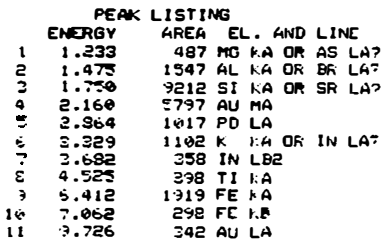

$\pi 1-5 \infty$

rursor: 0 bookev =

MHA oO-cet-ot $12: 15$

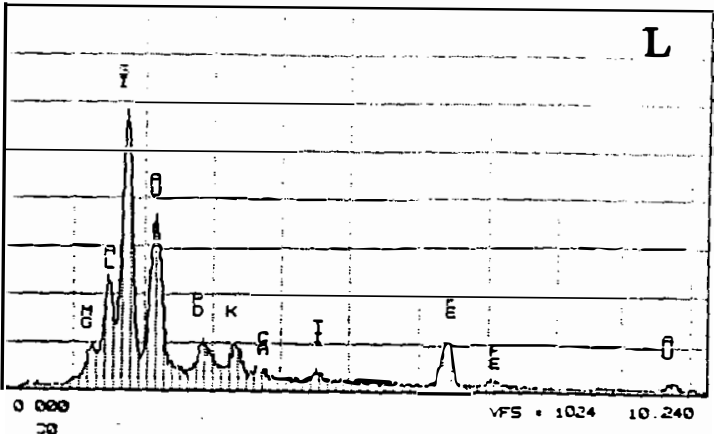

Figura 4.20. Picos espectrais das micrografias I. J, K. L. 
OUKLITATIVE EIERENT IDEHTIFICATIOH

SADE ID:T-15

POSEIELE IDENTIFICATICES

SE KA SI KA On SR LAE

PEAK LISTINE $\begin{array}{lll}1 & 1.475 & 241 \text { ML KA OR GK LA: } \\ 3 & 1.755 & 316 \text { SI KA OR SR LA? } \\ 3 & E .400 & 1489 \mathrm{FE} \mathrm{KA}\end{array}$

TII- $\infty$

Tursori, $0.000 \mathrm{hev}=0$

hon OB-CEE-9: 70300

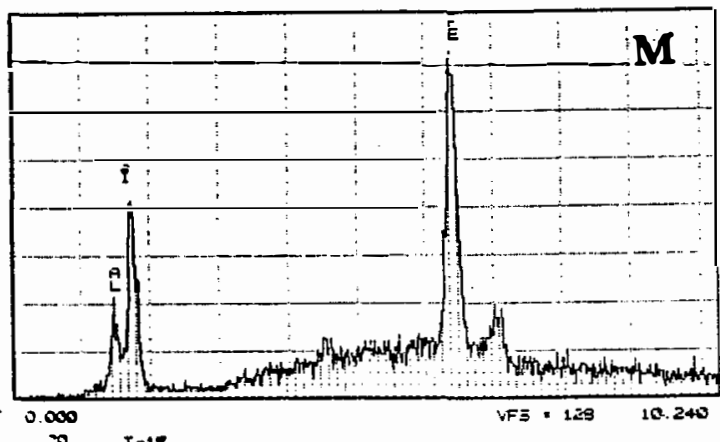

$=0 \quad T-1=$

QURLITATIVE EERENT IDENTIF ICATIOE

SAPR ID:T-44

POSSIBLE IDENTIFICATION

3I KA OR SR LA?

FE KA KB OR PD LA

AL KA OR BR LA?

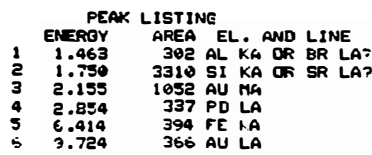

TN-S $\infty$

Eursort $0.000 \mathrm{kev}=0$

IMPS OB-CEC-T3 12:00

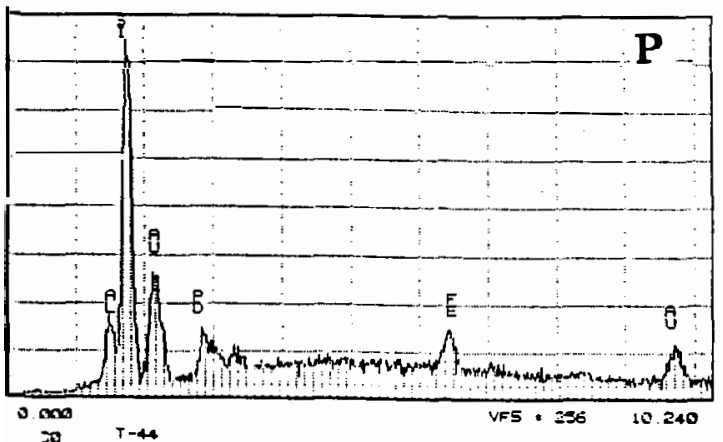

DUMLITATIVE ESENT IDENTIFICATIOH

SADPE ID:T-44

POSSIDE IDENTIFICATION

II KA OR SR LA?

NG LA OR AU LA MA

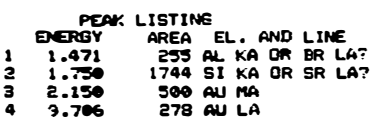

ni-s 00

iureor: $0.000 \mathrm{kev}$. 0

MNA De-DEC 97 15:20
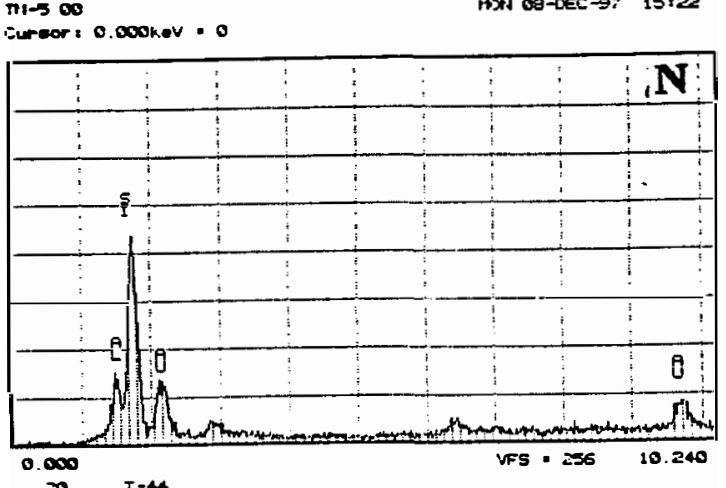

QUALITATIVE EERENT IDENTIFICATIOH

SAPLE 3D IT-44

POSSIRLE IDENTIF ICATION

SI KA OR SR LA?

NL KA OR QR LA?

FE KA

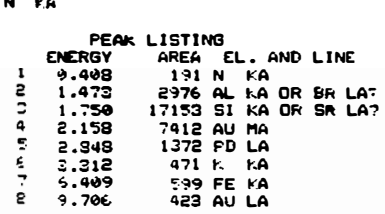

Ti- $1-50$

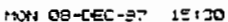

Eursor: $0.00 \mathrm{kev}=0$

$\mathbf{Q}$

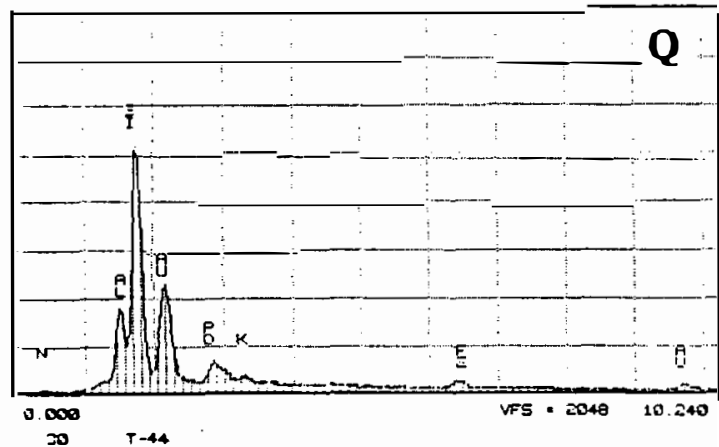

Figuras 4.20. Picos espectrais das micrografias $M, N, P, Q$. 


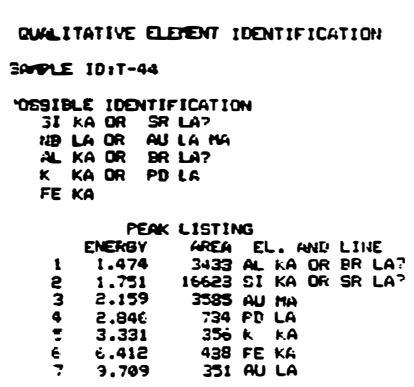

$\pi 1-2 \infty$

Eursor: 0.000hev = 0

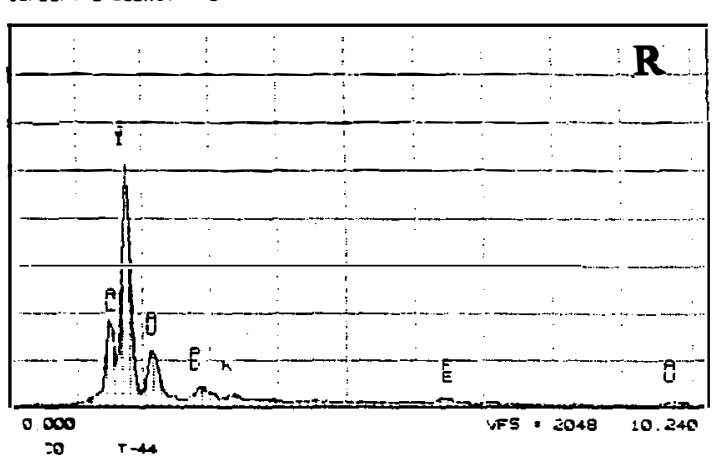

GUALITATIVE ELEMENT IDENTIFICATION SAMFLE IOIT-4S

-OSEIRLE IUENTIFICATION

MI KA OR SR LA?

ML KA OR OR LA?

FE IA $L A P$

CA TK KA OR IN LA?

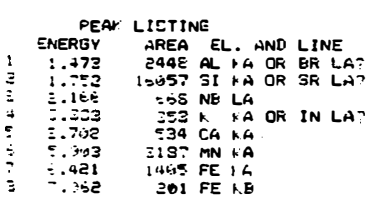

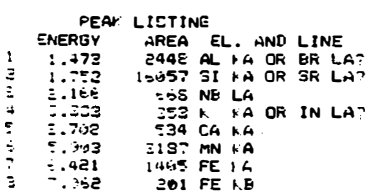

$\therefore i-\infty$

ursor, o soakev.

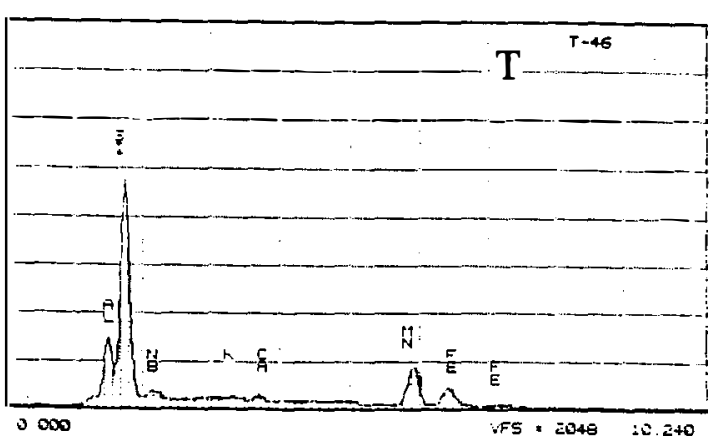

Figura 4.20. Picos espectrais das micrografias $\mathrm{R}, \mathrm{S}$ e $\mathrm{T}$.

خL I.A DR $9 R$ LA?

not OS-CEe -2: in: is
QUNLITATIVE ELEERTI IDENTIFICATION

SAMLE 10:T-42

POSSIBLE IDEUTIFICATI ONS

31 KA OR SR LA?

NE LA OF AU LA

FE KA
$N$

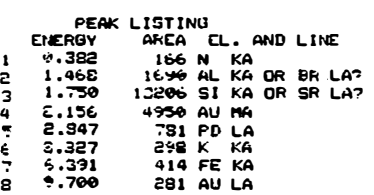

$\pi+5 \infty$

$\operatorname{nn}$ OS-LEC-97 14:46

Eursor: $0.000 \mathrm{kev} .0$

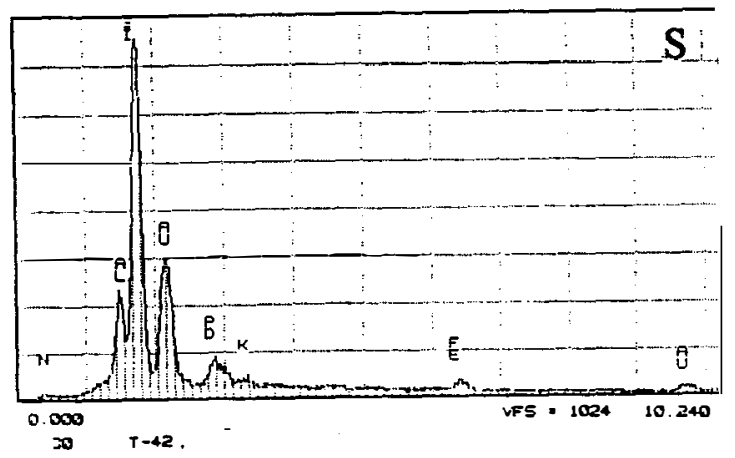




\section{CONCLUSÕES}

1. De acordo com os teores de titânio, considerado um dos elementos mais estáveis dos aqui determinados, indicam ser homogêneo e semelhante o material de origem para os quatro perfis estudados.

2. As principais causas que contribuiram para as variações dos atributos dos solos estudados se devem as reações infuenciadas pelo ambiente de oxi-redução.

3. As poucas evidências de translocação de argila, analisadas principalmente pelos dados das relações argila fina / argila total e análises micromorfológicos, sugerem outros processos para a formação do horizonte álbico, principalmente no T4. A presença de pequenos testemunhos do horizonte Bt no horizonte $\mathrm{E}$ do $\mathrm{T} 4$, assim como de materiasi reliquiais de plasma esmectítico com padrão de "favo de mel" em processo de alteração, indica que este horizonte se formou por degradação daquele horizonte argilico.

4. O aumento da acidificação assim como a redução das bases nos horizontes A e parte do B no T4, caracterizam um processo de ferrólise com destruição parcial ou total dos minerais do solo deixando a camada subsuperficial mais arenosa e esbranquecida.

5. A neo-formação de minerais 2:1 é confirmado principalmente nos horizontes Btv do T4 de CTC mais elevada de toda a seqüência de solos; assim como através das transformações da mica para esmectita indicado pelas análises pontuais.

6. O quartzo é o mineral predominante nas frações areia e silte, acompanhado pelos feldspatos calco-sódicos. $\mathrm{O} \mathrm{Na}$ da albita seria um dos responsáveis pela estrutura prismática, de tendência colunar, com características vérticas preferentemente no T4. 
7. Indo da base dos perfis para a superficie a tendência é dominar o processo de dessilicatização, com aumento do teor de caulinita. Por outro lado o processo de bissialitização predomina do T1 em direção ao T4 principalmente nos horizontes inferiores, com ocorrência de nontronita, micas e os interestratificados micavermiculita e mica-nontronita.

8. O processo de lessivagem foi mais evidenciado no $\mathrm{T} 1$.

9. Os exames micromorfológicos permitiram concluir que:

a) No PE (perfil T1), a porosidade aumenta de cavitária para fissural em profundidade, com uma assembléia de micro agregados delimitados por fissuras e cavidades policôncavas que envolvem os micro agregados, sugerindo um Bt em processo de latossolização; b). No caso do PL (perfil T4), a estrutura em cunha com evidentes slickensides apresentam micro rachaduras devido aos ciclos de umedecimento e dessecação com o acréscimo de argilominerais $2: 1$; c). Ficou evidenciado a destruição parcial e/ou total do Bt observado na transição E/Bt.

10. Os processos de atque químico aos minerais dos solos, causaram um rebaixamento na sequüência T1 e T4 e a formação da depressão. 


\section{REFERÊNCIAS BIBLIOGRÁFICAS}

ABREU, C.A. A extração com DTPA: Determinação de cobre, ferro, manganês e zinco em solos. Campinas: IAC- Instituto Agronômico de Campinas. 1996. 9p.

AB'SABER, A.N. Amazônia do discurso à práxis. São Paulo: Editora da Universidade de São Paulo, 1996. 320p.

AGBENIN, J.O.; TIESSEN, H. Soil properties and their variations on two contiguous hillslopes in Northeast Brazil. Catena, v. 24, n. 2, p.147-161, 1995.

AHMAD, N.; JONES, R.L. A Plinthaquult of the Aripo savannas, North Trinidad II. Mineralogy and genesis. Soil Sci. Soc. Am. Proc., v.33, n.5, p.765-768, Sep./Oct. 1969.

ALLEN, B.L.; HAJEK, B.F. Mineral occurrence in soil environments. In: DIXON, J.B.; WEED, S.W. (Eds.). Minerals in soil environments. $2^{\text {nd }}$ ed. Reprint 1995. Madison: SSSA Books series n.1. SSSA, chap.5, p.199-278, 1989.

ALMEIDA, J.; KLAMT, E.; KÄMPF, N. Gênese do contraste textural e da degradação do horizonte B de um Podzólico Vermelho- Amarelo da planície costeira do Rio Grande do Sul. Revista Brasileira de Ciência do Solo, v.21, n.2, p.221-233, Abr./Jun. 1997.

ALLISON, L.E. Organic carbon. In: BLACK, C.A. (Ed.). Methods of soil analysis. Part. 2. Chemical and microbiological properties. Madison: Am. Soc. of Agronomy, Inc. Pub. n,9, p.1367-1378. 1965.

ANTONY, L.M.K. Abundância e distribuição vertical da fauna do solo de ecossistemas amazônicos naturais e modificados. In: XXVI CONGRESSO BRASILEIRO DE 
CIÊNCIA DO SOLO. Resumos. Sociedade Brasileira de Ciência do Solo, 20-26 Jul. RJ, 1997, p107.

AOUDJT, H.; ROBERT, M.; ELSASS, F. et al. Detailed study of smectite genesis in granitic saprolites by analytical electron microscopy. Clay Minerals, v.30, n.2, p.135-147, 1995.

ATTA, S. K.; MOHAMMED, S.A.; CLEEMPUT,O. VAN; ZAYED, A. Transformation of iron and manganese under controlled Eh, Eh-pH conditions and addition of organic matter. Soil Technology, v.9, p.223-237, 1996.

BARBOSA, O.; GOMES, F.A. Pesquisa de petróleo da Bacia do rio Corumbatai, Estado de São Paulo. Rio de Janeiro: DNPM-DGM. 1958. (Boletim 171).

BENITES, J.R. Soils of the peruvian amazon: their potential for use and development In: WIENK, J.F.; WIT, H.A. (Eds.). Workshop on the management of low fertility acid soils of the American humid tropics. San José: IICA-University of Suriname, 1982, p.85-93.

BERG, M.V. DEN.; LEPSCH, I.F.; SAKAI, E. Solos de planícies aluviais do vale do rio Ribeira de Iguapé-SP. II. Relações entre características fisicas e químicas. Revista Brasileira de Ciência do Solo, v.11, p.315-321, 1987.

BIRKELAND, P.W. Soils and geomorphology. New York: Oxford University Press Inc., 1984. 372p.

BIRKELAND, P.W.; MACHETTE, M.N.; HALLER, K.H. Soil as tool for applied quaternary geology. Utah: Geological and mineral survey, 1990.63p.

BONIFACIO, R;. ZANINI, E.; BOERO, V.; FRANCHINI, A.M. Pedogenesis in a soil catena on serpentinite in North-Western Italy. Geoderma, v.75, p.33-51, 1997.

BOUMA, J. Hydrology and soil genesis of soils with aquic moisture regimes. In: WILDING, L.P.; SMECK, N.E \& HALL, G.F. (Eds.). Pedogenesis and Soil traxonomy. I. Concepts and interactions. Amsterdam: Elsevier, 1983, p.253-281.

BOUABID, R.; NATER, E.A.; BLOOM, P.R. Characterization of the weathering status of feldspar minerals in sandy soils of Minnesota using SEM and EDX. Geoderma, v.66, n.1-2, p.137-149, Apr. 1995 
BORCHARDT, G. Smectites. In: DIXON, J.B.; WEED, S.B. (Eds.). Minerals in soil environments. Madison: SSSA. A. Books series, n.1, 1989, chap. 14, p.675-727.

BOZZOLA, J.J.; RUSSELL, L.D. Electron microscopy principles and techniques for biologists. Boston: Jones \& Bartlett Publishers, 1992. 542p.

BREWER, R. Fabric and mineral analysis of soils. New York: John Wiley \& Sons Inc., 1964. 470p.

BREWER, R. Fabric and mineral analysis of soils. New York: Robert E. Krieger Publishing Co. 1976. 482p.

BRINKMAN, R. Ferrolysis a hiydromorphic soil-forming process. Geoderma, v.3, p.199-206, 1970.

BRINKMAN, R. Ferrolysis, a soil-forming process in hydromorphic conditions. Agric. Res. Rep. 887, Wageningen : Pudoc, 1979. 106p.

BROWN, G. (Ed.). The X-ray identification and crystal structures of clay minerals. London: Mineralogical Society, 1961. 544p.

BUOL, S.W.; HOLE, F.D.; MCCRACKEN, R.J. Génesis y clasificación de suelos. México: Editorial Trillas, $1^{\mathrm{a}}$ reimpresión, 1983. 417p.

BUOL, S.W.; HOLE, F.D.; MCCRACKEN, R.J.; SOUTHARD, R.J. Soil genesis and classification. $4^{\text {th }}$ ed. Ames: Iowa State University Press, 1997. 527p.

CABRERA- MARTINEZ, F.; HARRIS, W.G.; CARLISLE, V. W. \& COLLINS, M.E. Evidence for clay translocation in coastal plain soils with sandy/loamy boundaries. Soil Sci. Soc. Am. J., v. 53, p.1108-1114, 1989.

CHAUVEL, G. Recherches sur la transformation des sols ferralitiques dans la zone tropicale a saisons contrasteés. ORSTON- Sér. Travaux et Document, n.62, 1977. $532 p$.

CADY, J.G. Mineral occurrence in relation to soil profile differentiation. In: DREW, J.V. (Eds.). Selected papers in soil formation and classification. Madison: SSSA Spec. Pub. series 1, p. 336-341. 1967.

CALERO-MERINO, M. Introdución a la geología com énfasis en ciencias agrícolas. Piura: UNP -Departamento Académico de Suelos, 1989. 105p. 
CALERO-MERINO, M. Génesis, morfologia y taxonomía de Aridisols, Entisols, Inceptisols, Alfisols y Ultisols del Departamento de Piura. Lima, 1987. 135p. Tesis (M.Sc.)- Escuela de P.G., UNA-La Molina.

CALERO-MERINO, M.; KLEIN, V.A.; DEMATTÊ, J.L.I. Caracterização micromorfológica de um Podzólico Vermelho-Escuro, em processo de latossolização na região de Piracicaba. In: XXVI CONGRESSO BRASILEIRO DE CIÊNCIA DO SOLO, Resumos. Sociedade Brasileira de Ciência do Solo, 20-26 Jul., 1997, RJ, p.321.

CALERO-MERINO, M.; DEMATTÊ, J.L.I.; CLEMENTE, C.A. Genesis, mineralogical and micromorphological attributes of three tropical soils developed from carbonate Permian sediments in Piracicaba-Brazil. $16^{\text {th }}$ World Congress of Soil Science, Montpellier-France: ISSS, August 20-26, Résumés-Summaries, v.1, p.312, 1998.

CAMARGO, O.A.de.; MONIZ, A.C.; JORGE, J.A.; VALADARES, J.M.A.S. Métodos de análise quimica, mineralógica e fisica de solos do Instituto Agronômico de Campinas. IAC. Boletim técnico, n. 106, p.94, 1986.

CAMARGO, M.N.; KLAMT, E.; KÄUFFMAN, J.H. Classificação de solos usada em levantamentos pedológicos no Brasil. Campinas. Boletim Informativo da Sociedade Brasileira de Ciência do solo, v. 12, n. 1, p.11-13, Jan./Abr. 1987.

CASS, A.; JOHNSTON, M.A. Physical and mineralogical properties of some Natal and Eastern Transvaal soils. South African Journal of Plant and Soil, v. 1, n.2, p.7984, 1985.

CASTRO, S.S. Micromorfologia de solos- Pequeno guia para descrição de lâminas delgadas. São Paulo: Departamento de Geografia. USP-IPT-DMGA, 1989. 87p.

CATT, J.A. Soil and quaternary geology. A handbook for field scientists. Oxford: Clarendon Press, 1986. 267p.

CHESWORTH, W. Geochemistry of micronutrients. In: LUXMOORE, R.J. Micronutrients in agriculture. $2^{\text {nd }}$ edition. Madison: SSSA Books series, n.4, 1991., chap. 1, p.1-29.

CLAUER, N.; WEBER, F.; GAUTHIER-LAFAYE, F.; TOULERIDIS, T.; SIZUN, J.P. Mineralogical, geochemical (REE), and isotopic ( $\mathrm{K}-\mathrm{Ar}, \mathrm{Rb}-\mathrm{Sr}, \delta^{18} \mathrm{O}$ ) evolution of 
the clay minerals from faulted, carbonate-rich, passive paleomargin of Southeastern massif central, France. Journal of Sedimentary Research, v.67, p.923-934, Sep. 1997.

CLEMENTE, C.A. Alterações e solos desenvolvidos sobre rochas vulcânicas ácidas da Formação Serra Geral nos planaltos de Guarapuava e Palmas, região Centro Sul de São Paulo do Estado de Paraná.1988. 207p.Tese (Doutorado)- Escola Superior de Agricultura "Luiz de Queiroz", Universidade de São Paulo.

CLOTHIER, B.E.; POLLOK, J.A.; SCOTTER, D.R. Mottling in soil profiles containing a coarse-textured horizon. Soil Sc. Soc. Am. J, v.42,n.5,p.761-763, Sep./Oct. 1978.

COLLINS, J. F.; BUOL, S.W. Patterns of iron and manganese precipitation under specified Eh-pH conditions. Soil Science, v.110, p.157-162, Jul./Dec. 1970.

COOPER, M. Estratigrafia e pedogênese de uma seqüência de solos com $B$ latossólico e B textural em Piracicaba (SP). Piracicaba. 1996. 141p. Dissertação (M.S). Escola Superior de Agricultura "Luiz de Queiroz", Universidade de São Paulo.

COSTA DE LEMOS, R.; DOS SANTOS, R.D. Manual de descrição e coleta de solo no campo. $2^{\text {a }}$ ed. Campinas: SBCS/ SNLS, 1984. 46p

DAEMON, R.F.; QUADROS, L.P. Bioestratigrafia do Neopaleozóico da Bacia do Paraná. In: CONGRESSO BRASILEIRO DE GEOLOGIA, Brasília, 1970. Anais. Brasilia. SBG, 1970, p.359-412.

DANIELS, R.B.; SIMONSON, G.H.; HANDY, R.L. Ferrous iron content and color of sediment. Soil Science, v.91, p.378-382, Jun. 1961.

DECHEN, S.C.F.; DEMATTÊ, J.L.I.; MARCONI, A. Caracterização granulométrica e mineralógica de três perfis de solos desenvolvidos do Arenito Bauru no Estado de São Paulo. Revista Brasileira de Ciência do Solo, v. 18, p.499-51 1, 1994.

DEMATTÊ, J.L.I. Mineralogia da fração argila de perfis de solos da série Piracicaba. Anais da E.S.A. 'Luiz de Queiroz", v.25, p.51-68, 1968.

DEMATTÊ, J.L.I. Gênese e classificação de solos originados do grupo geológico Estrada Nova, no municipio de Piracicaba. ESALQ/USP. Piracicaba, 123p. 1970. 
DEMATTÊ, J.L.I.; MONIZ, A.C.; PESSOTI, J.E.S. Solos originados de sedimentos do grupo geológico Estrada Nova do município de Piracicaba. Revista Brasileira de Ciência do Solo, v. 1, n. 1, p.43-47, 1977.

DEMATTÊ, J.L.I.; HOLOWAYCHUCK, N. Solos da região de São Pedro, Estado de São Paulo. II. Mineralogia. Revista Brasileira de Ciência do Solo, v.1, p.99-103, 1977.

DEMATTÊ, J.L.I. Zircônio e titânio da fração areia de solos. Revista Brasileira de Ciência do Solo, v.2, p.74-77, 1978.

DEMATTÊ, J.L.I. Manejo de solos ácidos dos trópicos úmidos região amazônica Campinas: Fundação Cargill, 1988. 215p

DEMATTÊ, J.L.I.; MARCONI, A.; SPAROVEK, G. et al. Estimativa da evolução do intemperismo mediante ganhos e perdas de ions numa seqüência de solos desenvolvidos de diabásio e influenciados pela drenagem em Piracicaba, SP. Revista Brasileira de Ciência do Solo, v. 15, n. 1, p.69-73, Jan./Abr. 1991.

DEMATTÊ, J.L.I.; MARCONI, A. A drenagem na mineralogia de solos desenvolvidos de diabásio em Piracicaba-SP. Revista Brasileira de Ciência do Solo, v.15, n.1, p.1-8, Jan./Abr. 1991.

DEMATTÊ, J.L.I.; VIDAL-TORRADO, P.; SPAROVEK, G. Influência da drenagem na morfogênese de solos desenvolvidos de rochas básicas no município de PiracicabaSP. Revista Brasileira de Ciência do Solo, v. 16, n.2, p.241-247, 1992.

DEMATTÊ, J.L.I.; DEMATTÊ, J.A.M. Comparações entre as propriedades quimicas de solos das regiões de floresta amazônica e do Cerrado do Brasil Central. Sciência Agrícola, v.50, n.2, p.272-286, Jun./Set. 1993.

DEMATTÊ, J.L.I.; DEMATTÊ, J.A.M.; MAZA, J.A. Gênese de uma toposseqüência Latossolo Amarelo- Podzólico desenvolvida de material da Formação BarreirasEstado de Alagoas. Resumos. XXV CONGRESSO BRASILEIRO DE CIÊNCIA DO SOLO, v.3, p.1564-1566, 1995.

DIXON, J.B. Quantitative analysis of kaolinite and gibbsite in soils by differential thermal and selective dissolution methods. Clays and Clay Minerals. Proc. $14^{\text {th }}$ Conference. New York: Pergamon Press, p.83-89, 1966. 
DIXON, J.B. Kaolin and serpentine group minerals. In: DIXON, J.B.; WEED, S.B. (Eds.). Minerals in soil environments. Madison: SSSA Books series, n. 1, 1989, chap. 10, p.467-525.

DORAN, J.W.; SARRANTONIO, M.; LIEBIG, M.A. Soil healthy and sustainability. Advances in Agronomy, v.56, p. 1-45, 1996.

DOUGLAS, L.A. Vermiculites. In: DIXON, J.B.; WEED, S. (Eds.). Minerals in soil environments. Madison: SSSA Books series n. 1, chap. 13, p.635-674, 1989.

DUCHAUFOUR, P. Pedology, pedogenesis and classification. London: George Allen \& Unwin, 1982. 443p.

DUCLOUX, J.; GUERO, Y.; FALLAVIER, P. Clay particle differentiation in alluvial soils of Southwestern Niger (West Africa). Soil Sc. Soc. Am. J., v.62, n.1, p.212222, Jan./Feb. 1998.

ELGAWHARY, S.M.; LINDSAY, W.L. Solubility of silica in soils. Soil Sc. Am. Proc., v.36, p.439-447, 1972.

EMPRESA BRASILEIRA DE PESQUISA AGROPECUÁRIA. Serviço Nacional de Levantamento e Conservação de Solos. Manual de métodos de análises de solos. Rio de Janeiro: Ministério de Agricultura, 1979, n.p.

EMPRESA BRASILEIRA DE PESQUISA AGROPECUÁRIA. Serviço Nacional de Levantamento e Conservação de Solos. Sistema Brasileiro de Classificação de Solos. 2a aproximação. Rio de Janeiro: EMBRAPA/SNLCS, 1981. 107p.

EMPRESA BRASILEIRA DE PESQUISA AGROPECUÁRIA. Serviço Nacional de Levantamento e Conservação de Solos. Normas e critérios para levantamentos pedológicos. Rio de Janeiro: EMBRAPA/SNLCS, 1989. 94p.

EMPRESA BRASILEIRA DE PESQUISA AGROPECUÁRIA. Manual de métodos de análise de solos. $2^{a}$ edição. Rio de Janeiro: EMBRAPA/CNPS, 1997. 212p.

ESCOBAR, E.H.; DEMATTÊ, J.L.I; MONIZ, A.C. Gênese e classificação de alguns solos da Bacia de Ribeirão Tijuco, municipio de Rio Das Pedras, SP. I. Análise mineralógica quantitativa da fração argila, Bragantia, v.32, n.3, p.93-113, 1973.

ESTRADA, J.A. Mineralogical and chemical properties of peruvian acid tropical soils. Riverside, 1971. 185p. Thesis (Ph.D.). University of California. 
ESWARAN, H.; STOOPS, G.; SYS, C. The micromorphology of gibbsite forms in soils.

The Journal of Soil Science, v.28, n.1, p.136-143, March. 1977.

ESWARAN, H.; SYS, C. Argillic horizon in LAC soils: formation and significance to classification. Pedologie, Ghent, v.29, p.175-190, 1979.

FANNING, D.S.; FANNING, M.C.B. Soil morphology, genesis and classifications. USA: John Wiley \& Sons, Inc. 1989, p.25-41.

FICHTER, J.; TURPAULT, M.P.; DAMBRINE, E.; RANGER, J. Mineral evolution of acid forest soils in the Strengbach Catchment (Vosges mountains, N-E France). Geoderma, v. 82, n.4, March. 1998.

FITZPATRICK, E.A. Soils their formation, classification and distribution. London: Longman Inc., 1983. 353p.

FITZPATRICK, E.A. Soil microscopy and micromorphology. Chichester: John Wiley \& Sons, Inc. 1993. 304p.

FLOATE, M.J.S.A. A chemical, physical and mineralogical study of soils developed on glacial lacustrine clays in north central British Columbia. Ca. J. Soil Sc., Ottawa, v. 46, p.227-236, 1966.

FOLK, R.L.; WARD, W.C. Brazos river bar: A study in the significance of grain size parameters. Journal Sedimentary Petrology, v.27, p.3-27, 1957.

GAMBLE, E.E.; DANIELS, R.B. \& MCCRACKEN, R.J. A A $_{2}$ horizons of coastal plain soils. Pedogenic or geologic origin. Sout Geol., Durhan, v.11, n.3, p.137-152, 1970.

GERASINOVA, M.I. Surface gleying of sod-podzolic soils. Soviet Soil Science, v.13, n.2, p.11-17, Mar./ Apr. 1981.

GERRARD, J. Soils and landforms. An interaction of geomorphology and pedology. London: Allen \& Uwin Pub., 219p. 1981.

GERRARD, J. Soil geomorphology. An introduction of pedology and geomorphology. London; Chapman \& Hall, 1995. 269p.

GLASMANN, J.R.; SIMONSON, G.H. Alteration of basalt in soils of Western Oregon. Soil Sc. Soc. Am. J., v.49, n.1, p.262-273, Jan./Feb. 1985. 
GOL'EVA, A.A. Biomorph analysis as a component of the genetic and morphological study of soil. Eurasian Soil Science, v.30, n.9, p.927-936, 1997.

GOTOH, S.; PATRICK, Jr. W.H. Transformation of iron in a waterlogged soil as influenced by redox potential and pH. Soil Sc. Soc. Am. Proc., v.38, n.1, p.66-71, Jan./Feb. 1974.

HACHIRO, J. Litotipos, associações faciológicas e sistemas deposicionais da Formacão Irati no Estado de São Paulo. São Paulo, 1991. 175p. Dissertação (M.S.)-Instituto de Geociências, Universidade de São Paulo.

HACHIRO, J.; COIMBRA, A.M. \& MATOS, S.L.F. O caráter cronoestratigráfico da Unidade Irati. In: SIMPÖSIO SOBRE CRONOESTRATIGRAFIA DA BACIA DO PARANÁ, 1. Rio Claro, 1993. Resumos, Rio Claro, IG-UNESP, p.62-63.

HACHIRO, J. O Subgrupo Irati (Neopermiano) da Bacia do Paraná. São Paulo, 1997. 196p. Tese (Doutorado)-Instituto de Gociências, Universidade de São paulo.

HALL, G.F. Pedology and geomorphology. In: Pedogenesis and Soil taxonomy. I. Concepts and interactions. New York: Elsevier Science. Pub. Bol., 1983, p.117140.

HEM, J.D.; LIND, C.J. Chemistry of manganese precipitation in Pinal Creek, Arizona, USA: A laboratory study. Geochimica et Cosmochimica Acta, v.58, n.6, p.16011613, March. 1994.

HILL, D.E.; SAWHNEY, B.L. Electron microprobe analysis of thin section of soils to observe loci of cation exchange. Soil Sc. Soc. Am. Proc., v.33, n.4, p.531-534, Jul./Aug. 1969.

HOLE, F. D. A classification of pedoturbations and some other processes and factors of soil formation in relation to isotropism and anisotropism. Soil Science, v.91, p.375377, Jun. 1961.

HUGGETT, R.J. Soil-landscape systems: A model of soil genesis. Geoderma, v.13, p.122, 1975.

INSKEEP, W. P.; CLAYTON, J.L.; MOGK, D.W. Naturally weathered plagioclase grains from Idaho batholith: observations using scanning electron microscopy. Soil Sc. Soc. Am. J., v.57, n.3, p.851-860, May./Jun. 1993. 
INSTITUTO DE PESQUISAS TECNOLÓGICAS DO ESTADO DE SÃO PAULO (IPT). Mapa geológico do Estado de São Paulo. Escala 1: 1.000.000. Divisão de Minas e Geologia Aplicada. São Paulo, 1981.

JACKSON, M.L. Soil chemical analysis. Advance course. $2^{\text {nd }}$ ed. Madison: University of Wisconsin-Department of Soil Science, 1969. 895p.

JENNY, H. Factors of soil formation. New York: McGraw-Hill, 281p. 1941.

JENNY, H. Derivation of state factor equations soil and ecosystems. Soil Sc. Soc. Am. Proc., v.25, n.5, p.385-388, Sep./Oct. 1961

JIMENEZ-RUEDA, J.R.; DEMATTÊ, J.L.I. Solos originados de lamitos da Formação Marilia (Grupo Bauru) da região de Monte Alto (SP). Revista Brasileira de Ciência do Solo, v.12, n.2, p.161-170, Maio./Ago. 1988.

JOHN, L.; GRIM, R.; BRADLEY, J. Quantitative estimation of clay minerals by diffraction of clay minerals methods. Journal Sedimentary Petrology, v.24, p.242$251,1954$.

JONES, A.A. Making standards for determining concentration of elements and oxides by $\mathbf{x}$-ray fluorescence spectrometry (XRFS). England: Department of Soil Science (Laboratory notes), University of Reading, 1986. 2p.

JONES, L.H.P.; HANDRECK, K.A. Effects of iron and aluminum oxides on silica in solution in soil. Nature. v. 198, p.852-853, Jun. 1963.

JONES, R.L. Determination of opal in soil by alkali dissolution analysis. Soil Sc. Am. Proc., v.33, n.6, p.976-978, Nov./ Dec. 1969.

JONGMANS, A.G.; OORT, F. VAN.; NIEUWENHUYSE, A.; et al. Inheritance of 2:1 phyllosilicates in Costa Rican Andisols. Soil Sc. Soc. Am. J., v.58, p.494-501, 1994. JONGMANS, A.G.; DENAIX, L.; OORT, F. Van. Isotropic smectite coatings and spheroids in Holocene volcanic deposits under temperature climate, France. Soil Sc. Soc. Am. J., v.62, n. 1, p.287-295, Jan./Feb. 1998.

JUNGERIUS, P.D.; LEVELT, T.W.M. Clay mineralogy of soils over sedimentary rocks in Eastern Nigeria. Soil science, v.97, p.89-95, Jan./Jun. 1963. 
KÄMPF, N.; KLAMT, E. Mineralogia e gênese de Latossolos (Oxisols) e solos Podzólicos da região do Planalto Sul-Riograndense. Revista Brasileira de Ciência do Solo, v.2, n. 1, p.68-73, Jan./Abr. 1978.

KÄMPF, N.; SCHWERTMANN, U. The 5M-NaOH concentration treatment for iron oxides in soils. Clays and Clay Minerals, Ottawa, v.30, p.401-408, 1982.

KÄMPF, N.; SCHWERTMANN, U. Goethite and hematite in a climosequence in Southern Brazil and application in classification of kaolinite soils. Geoderma, v.29, n.1, p.27-39, Jan. 1983.

KÄMPF, N.; SCHWERTMANN, U. Relações entre óxidos de ferro e a cor em solos cauliniticos do Rio Grande do Sul. Revista Brasileira de Ciência do Solo, v.7, p.27-31, Jan./Abr. 1983.

KARATHANASIS, A.D.; ADAMS, F.; HAJEK, B.F. Stability relationships in kaolinite, gibbsite, and Al-hydroxinterlayered vermiculite soil system. Soil Sc. Soc. Am. J., v.47, n.6, p.1247-1251, Nov./Dec. 1983.

KARATHANASIS, A.D.; THOMPSON, Y.L. Mineralogy of iron precipitates in a constructed acid mine drainage wetland, Soil Sc. Soc. Am. J., v.59, p.1773-1781, 1995.

KARMANOVA, L.A. Effect of parent materials and of group differences between soils on the composition and distribution of various forms of iron. Soviet Soil Science, v.7, n. 1, p.75-82, Jan./Feb. 1975.

KARMANOVA, L.A. Effect of various iron compounds on the spectral reflectance and color of soils. Soviet Soil Science, v.13, n.5, p.53-60, Sep./Oct. 1981.

KITAJIMA, E.W. Curso introdutório de microscopia eletrônica de varredura. Piracicaba: ESALQ/USP- Núcleo de apoio à pesquisa em microscopia eletrônica aplicada à pesquisa agropecuária (NAP/MEPA), 1997. 37p.

KITTRICK, J.A. Soil minerals in the $\mathrm{Al}_{2} \mathrm{O}_{3}-\mathrm{SiO}_{2}-\mathrm{H}_{2} \mathrm{O}$ systems and a theory of their formation. Clay and Clays Minerals, v.17, p.157-167. 1969.

KRASIL'NIKOV, P.V. Transformation of phyllosilicates in the course of oxidation of sulfide-containing soil-forming-rocks. Eurasian Soil Science, v.30, n.10, p.11171126, 1997. 
KRETZSCHMAR, R.; ROBARGE, W.P.; AMOOZEGAR, A.; VEPRASKAS, M.J. Biotite alteration to halloysite and kaolinite in soil-saprolite profiles developed from mica schist and gneiss. Geoderma, v.75, nos 3-4, p.155-170, Feb. 1997.

LADEIRA, F.S.B. Formação, degradação e produtos de alteração de plintitas e petroplintitas ferruginosas. Disciplina de Gênese e Morfologia de Solos. ESALQ/USP, 1995. 28p.

LAFFAN, M.D.; DALY, B.K.; WHITTON, J.S. Podzolized soils on hilly and steep land near Tennyson Inlet, Marlborough Sounds, New Zeland: Classificatioon and relation to landform, slope and altitude. Australian Journal Soil Research, v.24, n.2, p.115-133, Apr. 1986.

LAVELLE, P.; BLANCHART, E.; MARTINI, A. Impact of soil fauna on the properties of soils in the humid tropics, In: SSSA: Myths and science of soils of the tropics. Madison: SSSA Special Publication, n.29, p.157-185, 1992.

LEMOS, R.C.; SANTOS, R.D. Manual de descrição e coleta do solo no campo. Campinas: SBCS/SNLCS, 1984. 46p.

LEINZ, V.; AMARAL, S.E. Do. Geologia Física Geologia Histórica, Brasilia: Instituto Nacional do Livro, 1975. 100p. (50-53).

LEPSH, I.F.; BUOL, S.W. Investigations in an Oxisol-Ultisol toposequence in São Paulo State, Brazil. Soil Sc. Soc. Am. Proc., v.38, p.491-496, 1974.

LEPSCH, I.F.; BUOL, S.W.; DANIELS, R.B. Soil landscape relationships in the occidental plateau of São Paulo, Brazil: I Geomorphic surface and soil mapping units. Soil Sc. Soc. Am. J., v.41, p.104-109, 1977.

LEPSCH, I.F. Solos: Formação e conservação. São Paulo: melhoramentos, 1992. 157p.

LIER, Q.J.; VAN, J.; TORRADO, P.V. PHI: Programa de microcomputador para análise estatística de granulometria de sedimentos. Revista Brasileira de Ciência do solo, v. 16, p.277-281, 1992 (notas).

LINDSAY, W.L. Chemical equilibria in soils. New York: John Wiley \& Sons Inc., 449p. 1979. 
LIMA, V.C.; DEMATTE, J.L.I.; MONIZ, A.C. Mineralogia da argila do Rubrozem (Palehumult), Bacia de Curitiba- Paraná. Revista Brasileira de Ciência do Solo, v.1, p.81-85, 1977.

LOZET, J.; MATHIEU, C.; JAMAGNE, M. Dictionary of soil science. $2^{\text {nd }}$ ed. New Delhi: Oxford \& IBH Publishing Co. PVT-LTD, 1991, p.1-295.

MCKEAGUE, J.A.; CLINE, M.G. Silica in soils. Advances in Agronomy, v. 15, p.339396, 1963.

MCKEAGUE, J.A. Manual on soil sampling and methods of analysis. $2^{\text {nd }}$ ed., Ottawa: Canadian Society of Soil Science, 1978. 212p.

MEHRA, O.P.; JACKSON, M.L. Removal of free iron oxides soils or clay by sodiumcitrate-bicarbonate-dithioniite (CBD) method. In: JACKSON, M.L. Soil chemical analysis. Advanced Course. Madison: University of Wisconsin. 1969, p. 44-58.

MELFI, A.J.; PEDRO, G. Estudo geoquímico dos solos e formações superficiais do Brasil. Revista Brasileira de Geociências, v.7, p.271-285, 1977.

MELFI, A.J.; PEDRO, G.; VOLKOFF, B. Natureza e distribuição dos compostos ferríferos nos solos do Brasil. Revista Brasileira de Ciência do Solo, v.3, p.47-54, 1979.

MELFI, A.J.; CERRI, C.; KRONGBER, C. et al. Granitic weathering: A Brazilian study: Journal of Soil Science, v.34, p.841-851, 1983.

MENDES, A.C.T.; FALCI, S.C.; DEMATTÊ, J.L.I. Seções delgadas de solos: Métodos de impregnação. Anais da ESALQ/USP, v.30, p.35-48, 1973.

MERMUT, A.R.; CURTIN, D.; ROSTAD, H.P.W. Micromorphology and submicroscopical features related to pyrite oxidation in an Inland marine shale from East central Saskatchewan. Soil Sc. Soc. Am. J., v.49, n.1, p.256-261, Jan./Feb. 1985.

MEZZALIRA, S. Contribuição ao conhecimento à geologia de sub-perficie e da paleontologia da Formação Irati no Estado de São Paulo, Academia Brasileira de Ciências. v.43 (Suplemento), p.273-336, 1971. 
MIROTA, M.D.; VEIZER, J. Geochemistry of Precambrian carbonate: VI. Aphebian Albanel Formations, Quebec-Canada. Geochimica et Cosmochimica Acta, v.58, n.7, p.1735-1745, 1994.

MODENESI-GAUTTIERI, M.C.; TOLEDO, DE M.C. Weathering and formation of hillslope deposits in the tropical highlands of Itatiaia-Southeastem Brazil. Catena, v.27, n.2, p.81- 103, Aug. 1996.

MÖLLER, M.R.F.; KLAMT, E. Intemperismo de argilominerais em Latossolo Roxo. Revista Brasileira de Ciência do Solo, v.7, p.33-38, Jan./Abr. 1983.

MONIZ, A.C.; BUOL, S.W. Formation of an Oxisol-Ultisol transition in São Paulo Brazil: I. Double-water flow model of soil development. Soil Sc. Soc. Am. J., v.46, p.1228-1233, 1982.

MONIZ, A.C.; GRANDE, M.A.; OLIVEIRA, V. Solos do trecho Cabo Frio-Xerém (RJ): Influência de regimes pluviais e de material de origem na pedogênese. Revista Brasileira de Ciência do solo, v. 14, p.205-214, 1990.

MONIZ, A.C.; MANFREDINI, S.; DEMATTÊ, J.L.I. Variações morofológicas, mineralógicas e hídricas em Terra Roxa Estruturada ao longo de uma vertente em Rio Das Pedras (SP). Revista Brasileira de Ciência do solo, v. 18, p.513-520, 1994.

MONIZ, A.C.; OLIVEIRA, J.B.; CURI, N. Mineralogia da fração argila de rochas sedimentares e de solos da Folha de Piracicaba, SP. Revista Brasileira de Ciência do Solo, v. 19, p.375-385, 1995.

MONIZ. A.C. Evolução de conceitos no estudo da gênese de solos. Revista Brasileira de Ciência do solo, v.20, p.349-362, 1996.

MOTTA, F.O. Mineralogia da região semi-árida do Estado de Ceará. Piracicaba, 1997. 205p. Tese (Doutorado)- Escola Superior de Agricultura "Luiz de Queiroz", Universidade de São Paulo.

MOORE, D.M.; REYNOLDS Jr, R.C. X-ray diffraction and identification and analysis of clay minerals. Oxford: Oxford University Press, 1989. $331 \mathrm{p}$.

MUSSA, D. Lignitafofloras permianas da Bacia do paraná, Brasil (Estado de São Paulo e Santa Catarina). São Paulo. 1982. 553p. Tese (Doutorado)- Instituto de Geociências, Universidade de São Paulo. 
NETTLETON, W.D.; WITTY, J.E.; NELSON, R.E.; HAWLEY, J.W. Genesis of argillic horizon in soils of desert areas of Southweastern United States. Soil Sc. Soc. Am. Proc., v.39, n.5, p.919-926, Sep./Oct. 1975.

NETTLETON, W.D.; ESWARAN, H.; HOLZHEY, C.S.; NELSON, R.E. Micromorphological evidence of clay translocation in poorly dispersible soils. Geoderma, v.40, p.37-48, 1987.

OLIVEIRA, J.B.; JACOMINE, P.K.T.; CAMARGO, M.N. Classes gerais de solos do Brasil. Guia auxiliar para seu reconhecimento. $2^{\text {a }}$ ed. Jaboticabal: FUNEP, 1992 $201 p$.

OMETTO, J,C. Registros e estimativas de parâmetros meteorológicos da região de Piracicaba, São Paulo: FEALQ, 1991. 76p.

PEASE, D.S.; ANDERSON, J.U. Opal phytoliths in Bouteloua eriopoda Torr. Roots and soils. Soil Sc. Soc. Am. Proc., v.33, n.2, p.321-322, March./Apr. 1969.

PEIFFER, S. Reactions of $\mathrm{H}_{2} \mathrm{~S}$ with ferric oxides. Some conceptual ideas on its significance for sedimentar-water interactions. In: BACKER, L.A. (Ed,). Environmental chemistry of lakes and resrvoirs. Advances in Chemistry series 237. Washington: Am. Chem. Soc., 1994, p.371-390.

PENTEADO, M.M. Geomorfologia do setor Centro-Ocidental da Depressão Periférica Paulista. São Paulo, 1976. 86p. Tese (Doutorado)- Instituto de Geografia, Universidade de São Paulo.

PERECIN, D.; FERRAZ DE C. Evidências micromorfológicas de gênese de solos de Piracicaba- SP. In: CONGRESSO BRASSILEIRO DE CIÊNCIA DO SOLO. Campinas 14-20 Jul. 1975, p.461-466.

PERES FILHO, A.; DONZELLI, J.B \& LEPSCH, I.F. Relações solo geomorfologia em várzea do Rio Mogi-Guaçu (SP). Revista Brasileira de Ciência do Solo, v.4, p.181-187, 1980.

PETRI, S.; FÚLFARO, V.J. Geologia do Brasil. São Paulo: Editora da Universidade de São Paulo, 1983.631p.

PETTIJOHN, F.J. Sedimentary rocks. $2^{\text {nd }}$ ed. New York: Harper \& Row Publishers, 1957. $718 \mathrm{p}$. 
PHILIPS, D.H.; AMMONS, J.T.; LEE, S.Y.; LIETZKE. D.A. Deep weathering of calcareous sedimentary rock and the distribution of iron and manganese in soil and saprolite. Soil Science, v. 163, n. 1, p.71-81, Jan. 1998.

PONNAMPERUMA, F.N. The chemistry of submerged soils. Advances in Agronomy, v.24, p.29-96, 1972.

QUEIROZ NETO, J.P.; CASTRO, S.S.; FERNANDES BARROS, O.N. et al. Um estudo de dinâmica de solos. Formação e transformação de perfis com horizonte $B$ textural. In: XVIII CONGRESSO BRASSILEIRO DE CIÊNCIA DO SOLO, 18; Salvador, 1980. Resumos. Campinas: SBCS, 1981.

RAGONHA, ER.W. Chondrochtyes do Membro Taquaral (Formação Irati) no Estado de São Paulo. São Paulo, 1978. 59p. Dissertação (M.S.)-Instituto de Geociências, Universidade de São Paulo.

RAIJ Van, B.; QUAGGIO, J.A.; CANTARELLA, H.; FERREIRA, M.E.; LOPES, A.; BATAGLIA, $O$. A análise química do solos para fins de fertilidade. Campinas: Fundação Cargill, 1983. 165p.

RANNEY, R.W.; BEATTY, M. Clay translocation and albic tongue formation in two glossoboralfs of West Central Wisconsin. Soil Sc. Soc. Am. Proc., v.33, n. 5, p.768774, Sep./Oct. 1969.

RANZANI, G.; FREIRE, O.; KINJO, T. Carta de solos do município de Piracicaba. Centro de Estudos de Solos- ESALQ/USP, 1966. 85p.

RESENDE, M. Mineralogy, chemistry, morphology and geomorphology of some soils of the Central Plateau of Brazil. Lafayette, 1976. 237p. Thesis (Ph.D.)- Purdue University.

RIBEIRO, M.R.; SANTOS, M.C.D.; FERREIRA, M. DA G. Caracterização e gênese de Podzólicos Vermelho-Amarelos do Sertão de Pernambuco. Revista Brasileira de ciência do Solo, v. 15, n. 1, p.75-81, Jan./Abr. 1991.

RICE, T.I.; BUOL, S.W.; WEED, S.B. Soil-saprolite profiles derived from mafic rocks in the North Carolina piedmont: I. Chemical, morphological, and mineralogical characterization and transformations. Soil Sc. Soc. Am. J., v.49, p. 171-178, 1985. 
RICHARDS, B.G.; PETER, P.; EMERSON, W.W. The effects of vegetation on the swelling and shrinkage of soils in Australia. London: Thomas Telford LTD, 1984, p.39-51.

ROBERT, T.M.; TESSIER, D. Incipient weathering: some new concepts on weathering, clay formation and organization. In: MARTINI, I.P.; CHESTWORTH, W. (Eds.). Weathering, soils \& paleosols. Amsterdam: Elsevier, 1992, chap. 4, p.71-103.

ROBINSON, D.A.; WILLIANS, R.B. Rock weathering and landform evolution. Chichester: John Wiley \& Sons Inc., 1994. 519p.

ROSS, J.L.; MOROZ, I.C. Mapa geomorfológico do Estado de São Paulo. Escala 1:500.000, v.1, São Paulo: Departamento de Geografia- FFLCH-USP, 1997. 64p.

ROSS, S.J.; FRANSZMEIER, D.P.; ROTH, C.B. Mineralogy and chemistry of manganese oxides in some Indiana soils. Soil Sc. Soc. Am. J., v.40, n. 1, p.137-143, Jan./Feb. 1976.

ROTTA, C.L. Mineralogia de solos de uma toposequência de Atibaia, SP. Boletim IGUSP, Publicação especial n.2, p.88, 1975.

RUHE, R.V. Quaternary landscapes in Iowa. Ames: Iowa State University Press, 1969. 255p.

SALEM, M.Z; HOLE, F.D. Ant (Formica exsectoides) pedoturbation in a forest soils. Soil Sc. Soc. Am. Proc., v.32, n.4, p.563-567, Jul./Aug. 1968.

SAWHNEY, B.L. Interstratification in layer silicates. In: DIXON, J.B.; WEED, S.B. Minerals in soil environments. $2^{\text {nd }}$ ed. Madison: SSSA Books series, n. 1, chap. 16, 1989, p.789-828.

SCHÖLTEN, T.; HENNINGSEN, P.F.; SCHOTTE, M. Geology, soils and saprolites of the Swaziland Middlevelt . Soil Technology, v.11, p.229-246, Oct. 1997.

SCHULZE, D.G. An introduction to soils mineralogy. In: DIXON, J.B.; WEED, S.B.

Minerals in soil environments. Madison: SSSA Books series n.1, chap.1, 1989, p. 1-19.

SHWERTMANN, U. Transformations of hematite to goethite in soils. Nature, v.232, n.5313, p.624-625, Aug. 1971. 
SCHWERTMANN, U.; MURAD, E.; SCHULZE, D.G. Is there Holocene reddening (hematite formation) in soils of axeric temperature areas?. Geoderma, v.27, n.3, p.209-223, Apr. 1982.

SCHWERTMANN, U; KÄMPF, N. properties of goethite and hematite in kaolinite soils of Southern and Central Brazil. Soil Science, v.139, n.4, p.344-350, Apr. 1985.

SCHWERTMANN, U.; LATHAM, M. Properties of iron oxides in some New Calcedonian Oxisols, Geoderma, v.39, n.2, p.105-123, Dec. 1986.

SCHWERTMANN, U. Iron oxides. In: DLXON, J.B.; WEED, S.B. (Eds.). Minerals in soil environments. Madison: SSSA Books series n.1, chap. 8, 1989, p.379-465.

SCHWERTMANN, U.; HERBILLON, A.J. Some aspects of fertility associated with the mineralogy of highly weathered tropical soils. In: Soil Science Society of America. Madison: SSSA Spec. Publication, n.29, p.47-59, 1992.

SHERMAN, G.D.; KANESHIRO, Y. Titanium. In: BLACK, C.A. (Ed.). Methods of soil analysis. Part. 2. Chemical and microbiological properties. Madison: Am. Soc. of Agronomy, Inc., Publication n.9, chap. 66, 1965, p.974-977.

SHOBA, S.A.; SOKOLOVA, T.A. Weathering products of biotite in Sod-Podzolic soil. Soviet Soil Science, v.13, n.6, p.91-97, Nov./Dec. 1981.

SILVA, A.C. Dinâmica da cobertura pedológica de uma área cratônica do Sul de Minas Gerais, Piracicaba, 1997. 191p. Tese (Doutorado)- Escola Superior de Agricultura "Luiz de Queiroz" Universidade de São Paulo.

SIMONSON, R.W. Outline of generalized theory of soil genesis. Soil Sc. Soc. Am. Proc., v.32, p.152-156. 1959.

SMECK, N.E.; WILDING, L.P.; HOLOWAYCHUCK, N. Genesis of argillic horizon in Celina and Marley soils of Western Ohio. Soil Sc. Soc. Am. Proc., v.32, n.4, Jul./Aug. 1968.

SOIL SURVEY SATAFF. Soil Survey Manual. U.S. Dept. Agric. Handbook n.18. Washington: U.S. Govt. Printing Office, 1951. 503p.

SOIL SURVEY STAFF. Soil Classification. A comprehensive system. $7^{\text {th }}$ approximation. Washington: Soil Conservation Service, 1960. 
SOIL SURVEY STAFF. Soil Taxonomy. A basic system of soil classification for making and interpreting soils surveys. Washington: USDA (Agric. Handbook n.436), 1975. 754p.

SOIL SURVEY STAFF. Keys of soil taxonomy. $4^{\text {th }}$ ed. Blacksburg-Virginia: AID-U. S. Dept. of Agric. Soil Conservation Service. SMSS Tech. Monograph n. 19, 1990. $422 p$.

SOKOLOV, I.A. on the tropical texturally differentiated soils with laterite and plinthite horizons. Eurasian Soil Science, v.30, n. 12, p.1263-1277, Dec. 1997.

SUGUIO, K. Introdução à sedimentologia. São Paulo: Edgard Blucher-USP, 1973. $317 \mathrm{p}$.

TAN, K.H.; SCHUYLENBORGH, VAN. On the classification and genesis of soils, derived from andesitic volcanic material under a monsoon climate. Netherlands Journal Agriculture, v. 7, p. 1-21, 1959.

TAN, K.H. Environmental soil science. New York: Marcel Dekker, Inc., 1994. 304p.

TAN, K.H. Soil sampling preparation, and analysis. New York: Marcel Dekker, In., 1996. 408p.

THORP, J. Effects of certain animals that live in soils. In: DREW, J.V. (Eds.). Selected papers in soil formation and classification. Madison: SSSA Spec. Pub. series n.l, p. 191-208, 1967.

TOLENTINO de C., G.B. Método rápido de determinação das relações $\mathrm{Ki}$ e $\mathrm{Kr}$ em solos. Rio de Janeiro: Boletim. IQA n.48- Ministério de Agricultura, 1956. 20p.

TORRENT, J.; SCHWERTMANN, U.; SCHULZE, D.G. Iron oxide mineralogy of some soils of two rivers terrace sequences in Spain. Geoderma, v.23, p.191-208, 1980.

TORRENT, J.; SCHWERTMANN, U.; FECHTER, H.; ALFEREZ, F. Quantitative relationships between soil color and hematite content. Soil Science, v.136, n.6, p.354-358, Dec. 1983.

TREMOCOLDI, W.A.; STEINHARDT, G.C. Gênese de solos Podzólicos derivados de arenitos da Formação Bauru do Estado de São Paulo. Revista Brasileira de Ciência do Solo, v.11, p.59-65, 1987. 
TRICART, J. As relações entre a morfogênese e a pedogênese. Notícia Geomorfológica, Campinas, v. 8, n. 15, p.5-18, Jun. 1968.

VAN BREEMEN, N. Long-term chemical, mineralogical, and morphological effects of iron-redox processes in periodically flooded soils. In: STUCKY, J.W.; GOODMAN, B.A.; SCHWERTMANN, U. (Eds.). Iron in soil and clay minerals. Dordrecht, Reidel, Proc. Nato Advanced Study Institute, p.81 1-823, 1988. (NATO 451 studies).

VAN GENUGTEN, M. Th. A closed-form equation for predicting the hydraulic conductivity of unsaturated soils. Soil Sc. Soc. Am. J., v.44, n.5, p.892-898, 1980.

VARGAS, M.A.T.; HUNGRIA, M. Biologia dos Cerrados. Planaltina: EMBRAPACPAC, 1997. 524p.

VEPRASKAS, M.J.; WILDING, L.P. Albic neoskeletans in argillic horizons as indices of seasonal saturation and iron reduction. Soil Sc. Soc. Am. J., v.47, n.6, p.12021208, Nov./Dec. 1983.

VERMA, S.D.; RUST, R.H. Observations in opal phytoliths in a soil biosequence in Southeastern Minnesota. Soil Sc. Soc. Am. Proc., v.33, n.5, p.749-751, Sep./Oct. 1969.

VERSTRATEN, J.M.; SEVINK, J. Clays soils on limestone in South Limburgh. The Netherlands, 2. Weathering. Geoderma, v.21, p.269-280, 1979.

VIDAL-TORRADO, P.; MAZZA, J.A.; CASTRO, S.S.; DEMATTÊ, J.L.I. Micromorfologia e gênese de um Podzólico Vermelho-Amarelo desenvolvido de sedimentos da Formação Itararé no distrito de Tupi (Piracicaba)-SP. In: XXIII CONGRESO BRASILEIRO DE CIÊNCIA DO SOLO, 23, Porto Alegre, 1991. Resumos. Campinas: SBCS, p. 275.

VIDAL-TORRADO, P.; LEPSCH, I.F. Morfogênese dos solos de uma toposseqüência com transição B latossólico/B textural sobre migmatitos em Mococa (SP). Revista Brasileira de Ciência do Solo, v. 17, n.1, p. 109-119, 1993.

VIDAL-TORRADO, P. Relações entre morfogênese e pedogênese no distrito de Tupi (Piracicaba-SP). Piracicaba, 1994. 214p. Tese (Doutorado)-Escola Superior de Agricultura "Luiz de Queiroz", Universidade de São Paulo. 
VIEIRA, L.S.; VIEIRA, M. DE N.F. Manual de morfologia e classificação de solos. São Paulo: Editora Agronômica Ceres Ltda, 1983. 313p.

VODYANISKII, Y.N.; TUROVA, E.S.; VAKYAN, Z.A. et al. Studing anerobiosis in a model experiment with kaolin. Eurasian Soil Science, v.30, n.7, p.747-757, Jul. 1997.

VOLKOFF, B.; MELFI, A.J.; CERRI, C.C. Solos Podzólicos e cauliníticos eutróficos do Alto Rio Purus (Estado do Acre). Revista Brasileira de Ciência do Solo, v.13, p.363-372, 1989.

WEED, S.B.; NELSON, L.A. Ocurrence of chlorite-like intergrade clay minerals in coastal plain, piedmont e mountain soils of North Carolina. Soil Sc. Soc. Am. Proc., v.26, p.393-398, 1962.

WESEMAEL, B. VAN.; VERSTRATEN, J.M.; SEVINK, J. Pedogenesis by clay dissolution on acid, low-grade metamorphic rocks under Mediterranean forest in Southern Tuscay (Italy). Catena, v.24, p. 105-125, 1995.

WEST, L.T.; DREES, L.R.; WILDING, L.P.; RABENHORST, M.C. Differentiation of pedogenic and lithogenic carbonate forms in Texas. Geoderma, v.43, p.271-287, 1988.

WEST, L.T.; BEINROTH, F.H.; SUMMER, M.E.; KANG, B.T. Ultisols characteristics and impacts on society. Advances in Agronomy, v.63, p. 179-263, 1998.

WILDING, L.P.; SMECK, N.E.; HALL, G.F. (Eds.). Pedogenesis and soil taxonomy.

II. The soil orders. Developments in soil science 11B. Amsterdam: Elsevier, 1983. 410p.

WILDING, L.P.; SMECK, N.E.; DREES, L.R. Silica in soils: Quartz, cristobalite, trydimite, and opal. In: DIXON, J.B.; WEED, S.B. (Eds.). Minerals in soil environments. Madison: Soil Sc. Soc. Am., p.471-552, 1977.

YECK, R. D.; GRAY, F. Phytholiths size characterisics between Udolls and Ustolls. Soil Sc. Soc. Am. Proc., v.36, n.4, p.639-641, Jul./Aug. 1972.

ZHANG, Y.L.; EVANGELOU, V.P. Influence of iron oxide forming conditions on pyrite oxidation. Soil Science, v. 161, n. 12, p.852-864. 1996. 


\section{APÊNDICE 1}

Caracterização morfológica dos perfis estudados 
Apêndice 1. Caracterização morfológica dos perfis estudados.

\section{PERFIL T-1}

DATA - 30/08/ 1996 .

CLASSIFICAÇÃO: Podzólico Vemelho-Escuro A Chernozêmico, Textura Argilosa/muito argilosa.. LOCALIZAÇÃO - Arraial de São Bento- Município de Saltinho, SP Brasil.

SITUAÇÀO, DECLIVE E COBERTURA VEGETAL SOBRE O PERFIL -Trincheira situada no terço médio superior da encosta, com $4 \%$ de declive, sob cultura de cana-de-açúcar.

ALTITUDE - 534 metros.

LITOLOGIA E CRONOLOGIA - Material da formação Irati, Permiano- Era Paleozóica.

MATETRIAL ORIGINÁRIO- Produtos do intemperismo de camadas plano-paralelas de sílica, argilitos e calcário dolomítico.

PEDREGOSIDADE- Não pedregoso na superfície, mas com horizontes e/ou camadas com cascalho, até muito cascalhenta na subsuperfície.

ROCHOSIDADE- Não rochosa superficialmente, com lage de sílex a mais de 2 metros de profundidade.

RELEVO LOCAL- Ligeiramente plano a suave ondulado, com microdepressões fechadas.

RELEVO REGIONAL- Ondulado.

EROSÃO- Não aparente.

DRENAGEM- Bem drenado.

VEGETAÇÃO PRIMÁRIA- Floresta latifoliada tropical.

USO ATUAL- Cana-de-açúcar.

CLIMA- Mesotérmico úmido subtropical da classificação de Köppen.

REGIMES DE UMIDADE E TEMPERATURA DO SOLO- "Udic e Hyperthermic" respectivamente. DESCRITO E COLETADO POR : M. Calero M.

\section{DESCRIÇÃO MORFOLÓGICA}

Ap - 0 - $30 \mathrm{~cm}$; bruno-Avermelhado-escuro (5YR 3/3, úmido e $5 \mathrm{YR} 3 / 3$, úmido amassado), brunoavermelhado a vermelho-amarelado (5YR 4/4, seco e 5YR 4/8, seco triturado); argila; moderada média e grande blocos subangulares; muito duro, friável, plástico e muito pegajoso; transição gradual e plana; bonecas de sílex: poucas, bem arredondadas, vermelho a bruno-avermelhado-claro (2,5YR 5/6, seco e 2,5YR 6/4, quebradas); nódulos: muito pouco, pequeno, duro, arredondado, preto (2,5 YR 2/0), ferromanganíferos, que efervescem à $\mathrm{H}_{2} \mathrm{O}_{2}$; poros pequeno comum; raízes comum. 
Bt1 - 30 - $83 \mathrm{~cm}$; bruno-avermelhado-escuro a vermelho-amarelado (2,5YR 3/4, úmido e $5 \mathrm{YR}$ 4/6, úmido amassado), vermelho-escuro a vermelho-amarelado (2,5YR 3/6, seco e 5YR 4/6, seco triturado); muito argiloso; moderada média e grande prismática que se desfaz em blocos subangulares, muito duro, friável, plástico e muito pegajoso; transição difusa e plana; bonecas de sílex: poucas, arredondadas, multiformes, pequeno ( $4 \mathrm{~mm}$ de diâmetro), vermelho a bruno muito claro-acinzentado (2,5YR 5/6, seco e 10YR 8/3, quebradas); sem nódulos; porosidade fissural; raízes poucas; cerosidade comum e contínua.

Bt2-w - 83 - 133 cm; bruno-avermelhado-escuro a vermelhado-amarelo (2,5YR 3/4, úmido e 5YR 4/6, úmido amassado), vermelho-escuro a vermelho-amarelado (2,5YR 3/6, seco e seco triturado); muito argiloso com cascalho de sílex; moderada média e grande prismática, que se desfaz em blocos subangulares; muito duro, firme, muito plástico, muito pegajoso; transição difusa e plana; bonecas de sílex: poucas, arredondadas, pequeno ( $3 \mathrm{~mm}$ em média), sendo o máximo $20 \mathrm{~mm}$, bruno-avermelhadoclaro a branco (2,5YR 6/4, seco e 7,5YR 8/0, quebradas); nódulos: muito pouco, pequeno (4 mm), duro, esférica, preto (2,5YR 2/0), ferromanganíferos (efervescem à $\mathrm{H}_{2} \mathrm{O}_{2}$ ); fragmentos de sílica angulares de 1 cm de diâmetro; porosidade fissural comum; cerosidade abundante e contínua.

Bt3 - 133 - $150 \mathrm{~cm}$; bruno-avermelhado-escuro a vermelho-amarelado (2,5YR 3/4, úmido e 5YR 4/6, úmido amassado), vermelho-escuro a vermelho-amarelado (2,5YR 3/6, seco e 5YR 5/6, seco triturado); muito argiloso, muito cascalhenta; moderada média e grande prismática, com cerosidade comum, pouco e contínua; que se desfaz em blocos subangulares; duro, muito friável, muito plástico, muito pegajoso; transição difusa e plana; bonecas de sílex: muito frequente $(60 \%$ cascalho $+40 \%$ calhaus $)$, grande ( $1-2$ $\mathrm{cm})$ e as mais pequenas $(2,5 \mathrm{~mm})$, atinguindo até $1 \mathrm{~mm}$ e misturando-se com o solo peneirado: duro, arredondada, achatada, bem arredondada, fragmentos irregulares de sílica $(3 \mathrm{~cm})$, vermelho a rosado (2,5YR 5/6, seco e 5YR 8/4, quebradas); nódulos: muito pouco, pequeno (4 mm), duro, esférica, preto (5YR 2/1, seco), ferromanganíferos, reação forte a comun á $\mathrm{H}_{2} \mathrm{O}_{2}$.

(BC)1 - 150 - $165 \mathrm{~cm}$; vermelho-escuro a vermelho-amarelado (2,5YR 3/6, úmido e 5YR 4/6, úmido amassado), com pontos amarelo-avermelhado a rosado (5YR 7/8 e 5YR 8/4, úmido amassado); vermelhoescuro a bruno-avermelhado-claro (2,5YR 3/6, seco e 5YR 6/4, seco triturado); muito argiloso, muito cascalhenta; moderada pequena e média, com fragmentos de prismática, que se desfaz em blocos subangulares; ligeiramente duro; muito friável, plástico, muito pegajoso; transição clara e plana; bonecas de sílex muito freqüente, pequeno $(5 \mathrm{~mm})$, duro, sobre material rico em sílica em pequenas camadas plano-paralelas, achatada e quebradas de $5 \mathrm{~mm}$ de espessura, intercaladas com bonecas de sílex 
subarredondada, vermelho a amarelo claro-acinzentado (2,5YR 5/6, seco e $5 \mathrm{Y} 7 / 8$, quebradas), com manchas superficiais preto (10YR 2/1, seco); sem nódulos.

C1 - 165 - $180 \mathrm{~cm}$; bruno-avermelhado-escuro (5YR 3/4, úmido e 5YR 3/3, úmido amassado), brunoavermelhado-escuro a bruno-avermelhado (5YR 3/4, seco e 5YR 4/4, seco triturado); muito argiloso com cascalho; moderada a forte pequena e média, blocos subangulares que se desfaz em granular muito pequena; duro, friável, plástico, pegajoso; transição clara e horizontal; poros pequeno comum; raízes pouco; bonecas de sílex: pouco, inseridas em fragmentos laminares plano-paralelos, com alternância de 3 $\mathrm{mm}$ de espessura, bem arredondada, mamilares, muito pequeno ( $3 \mathrm{~mm}$ ), vermelho-amarelado (5YR 5/6, seco), com manchas cinzento-rosado a cinzento (5YR 6/2 e 5YR 6/1, seco), com $30 \%$ da cor preta (5YR 2/1, seco); nódulos: muito pouco, pequeno, macio, arredondado, preto, ferromanganíferos; os torrões são rapidamente fragmentados reagindo fortemente à $\mathrm{H}_{2} \mathrm{O}_{2}$.

C2 - 180 - $211 \mathrm{~cm}$; vermelho-amarelado a bruno-avermelhado (5YR 4/8, úmido e 2,5YR 4/4, úmido amassado), vermelho amarelado a bruno-avermelhado (5YR 5/6, seco e 2,5YR 5/4, seco triturado); muito argiloso, fraca pequena laminar a muito pequena que se desfaz em blocos subangulares; camada ligeiramente ondulada formada por argilitos alternados por camadas de sílica de 3 a $10 \mathrm{~mm}$ de espessura, com plaquetas achatadas, que se fragmentam a formas angulares de 2 a $4 \mathrm{~cm}$; bonecas: pouco, muito pequeno (4 mm), duro, subarredondadas, mamilares, amarelo-avermelhado-claro (5YR 6/6, seco e 2,5YR 6/4, quebradas) e poucas manchas pretas (5YR 2/1, seco); aparente evidência de neotectônica ou pressão litostática?; todo o solo efervesce à água oxigenada; poros pequeno comum; raízes raras; sem nódulos.

C3 - 211 - $220 \mathrm{~cm}$; bruno-avermelhado-escuro (5YR 3/2, úmido amassado), cinzento -avermelhadoescuro a bruno-avermelhado-escuro (5YR 4/2, seco e 5YR 3/4, seco triturado), com pontos cinzento muito escuros (5YR 3/1, seco); muito argiloso; fraca média e pequena laminar que se desfaz em blocos subangulares; duro, firme, muito plástico, muito pegajoso; camadas de argilitos dispostos em lâminas alternadas com placas de sílica de $6 \mathrm{~mm}$ de espessura; bonecas de sílex: muito pouco, grande $(1,5 \mathrm{~cm})$ e as mais pequenas têm $3 \mathrm{~mm}$ de diâmetro, duro, mamilares, alongada, bruno-avermelhado a cinzento oliváceo-claro (5YR 5/4, seco e 5Y 6/2, quebradas), com 40\% de manchas preto (5YR 2/1, seco); foi encontrado um cristal de quartzo da cor branca $(7,5 \mathrm{YR} 8 / 0$, seco); não há presença de nódulos, todo o material efervesce à $\mathrm{H}_{2} \mathrm{O}_{2}$ até oxidar o material preto; aparência geral cor "café".

C4 - 220 - $235 \mathrm{~cm}$; bruno-forte e bruno-avermelhado-escuro (7,5YR 5/8, úmido-estrato e 5YR 3/4, úmido-solo) a vermelho-amarelado (5YR 5/6, úmido-amassado) com pontos rosado (5YR 8/4, úmido amassado), amarelo-avermelhado e vermelho-amarelo (7,5YR 7/8, seco-estrato e 5YR 4/6, seco -solo) a 
amarelo-avermelhado (5YR 6/6, seco triturado); muito argiloso; fraca média e pequena laminar, que se desfaz em blocos subangulares; duro, firme, muito plástico, muito pegajoso; transição abrupta e plana; estrato plano-paralelo (laminar) com bonecas de sílex: muito pouco, pequeno $(<1 \mathrm{~cm})$, duro, arredondadas e subarredondadas, amarelo-avermelhado-escuro (5YR 6/6, e 5YR 3/2, seco), estrato laminar rosado (5YR 8/4, seco), com manchas oxidadas bruno-avermelhado-escuro e preto (5YR 3/3 e 5YR 2/1, seco); os argilitos não efervescem à água oxigenada, mas sim os pontos pretos (Fe-Mn); não há nódulos; poros muito pequeno pouco; raízes raras.

C5 - 235 - 246 cm; bruno-avermelhado-escuro (5YR 3/2, úmido e 5YR 3/3, úmido amassado), cinzentoavermelhado-escuro a bruno-escuro (5YR 4/2, seco e 7,5YR 3/2, seco triturado); muito argiloso; muito cascalhenta; moderada muito pequena blocos subangulares que se desfaz em granular pequena; muito duro, firme, ligeiramente plástico, muito pegajoso; transição clara e plana; bonecas de sílex: muito freqüente $(+40 \%)$, grande até $1,5 \mathrm{~cm}$ de diâmetro e as pequenas $2 \mathrm{~mm}$, duro, mamilares, bem arredondadas, amarelo-avermelhado a cinzento (5YR 6/6, seco e 5YR 5/1, quebradas) com manchas pretas (5YR 2/1, seco, fragmentos de sílica cinzento-claro (5YR 7/1, seco); sem nódulos; porosidade fissural evidente; raízes raras.

C6 - 246 - 272 cm; vermelho-amarelado (5YR 4/6, úmido e úmido amassado), bruno-avermelhado-claro (5YR 6/4, seco e seco triturado); muito argiloso, cascalhenta; fraca pequena laminar intercalada com plaquetas achatadas de sílica de $4 \mathrm{~mm}$ de espessura, fragmentando-se em partículas angulares; ligeiramente duro, firme plástico, muito pegajoso. transição abrupta e plana; bonecas de sílica freqüente, variando de 2 até $10 \mathrm{~mm}$ de diâmetro, duro, subarredondadas, achatadas por aparente pressão litostática. com plaquetas de $2,5 \mathrm{~mm}$ e $1 \mathrm{~cm}$ de comprimento, bonecas bruno-avermelhado-claro a cinzentoavermelhado-escuro (5YR 6/4, seco e 5YR 4/2, quebradas), sem nódulos, outras bonecas são vermelhoacinzentado (10YR 5/4, seco), com manchas pretas; sem nódulos: poros pequeno pouco; sem raízes.

C7 - 272 - $286 \mathrm{~cm}$; bruno-avermelhado-escuro (5YR 3/3, úmido e 7,5YR 3/2, úmido amassado), vermelho-amarelado a bruno-escuro (5YR 4/8, seco e 7,5YR 4/4. seco triturado), com pontos pretos (2/0, úmido amassado); muito argiloso com casacalho: moderada pequena blocos subangulares que se desfaz em granular média; muito duro, friável, plástico. ligeiramente pegajoso; transição clara e plana; bonecas de sílica pouco, grande $(2 \mathrm{~cm})$ e pequeno $(2.5 \mathrm{~mm})$, duro. mamilares, bem arredondadas (maioria). inseridas em fragmentos de sílica intemperizada de $7 \mathrm{~mm}$ de espessura, cinzento-vermelho-escuro a cinzento (5YR 4/2, seco e 5YR 5/1, quebradas). com manchas preto (5YR 2/1), algumas bonecas estão muito intemperizadas; poros pequeno pouco; sem raízes nem nódulos. 
286 - $300 \mathrm{~cm}$; lage de silex intemperizada, bruno-avermelhado-escuro a bruno-avermelhado ( $5 \mathrm{YR} 3 / 3$, material intemperizado e 5YR 4/4, seco triturado); bonecas de silex: amarelo-avermelhado a vermelhoclaro-acinzentado (5YR 6/6, seco e 10R 6/4, quebradas) com fragmentos de sílica, amarelo-avermelhado, com manchas bruno-escuro e preto (7,5YR 6/6, seco; 7,5YR 3/2 - 2/0, seco-manchas), com formas e tamanhos similares às camadas e horizontes suprajacentes evidenciando a gênese destes solos.

\section{PERFIL T2}

DATA- $1 / 9 / 1996$.

CLASSIFICAÇÃO: PodzólicoVermelho Escuro Tb eutrófico A moderado, textura argilosa/muito argilosa.

LOCALIZAÇÀO- Arraial de são Bento-Municipio de Saltinho, SP Brasil.

SITUAÇÀO, DECLIVE E COBERTURA VEGETAL SOBRE O PERFIL- Trincheira situada no terço médio da encosta, com $4 \%$ de declive, sob cultura de cana-de-açúcar.

ALTITUDE- 532 metros.

LITOLOGIA E CRONOLOGIA- Sedimentos da formação Irati, Permiano-Era Paleozoica.

MATERIAL ORIGINÁRIO - produtos do intemperismo de camadas plano-paralelas de sílex, argilitos e calcário dolomítico.

PEDREGOSIDADE- Não pedregosa na superfície, mas com camadas com cascalho a muito cascalhenta $\mathrm{a}+$ de $140 \mathrm{~cm}$ de profundidade.

ROCHOSIDADE- Não rochosa superficialmente, com lage de sílex a $215 \mathrm{~cm}$.

RELEVO LOCAL- Ligeiramente plano a suave ondulado, com microdepressões fechadas.

RELEVO REGIONAL- Ondulado.

EROSÃO- Não aparente.

DRENAGEM- Bem drenado (superfície) e moderadamente drenado na subsuperfície.

USO ATUAL- Cana-de-açúcar.

CLIMA- Mesotérmico úmido subtropical da classificação de Köppen.

REGIMES DE UMIDADE E TEMPERATURA DO SOLO- "Udic e Hyperthermic" respectivamente.

\section{DESCRIÇÃO MORFOLÓGICA}

Ap - 0 - $30 \mathrm{~cm}$; bruno-avermelhado-escuro (5YR 3/4, úmido e úmido amassado), e bruno avermelhado (5YR 4/4. seco e seco triturado); franco argiloso; moderada média e pequena blocos subangulres que se 
desfaz em granular; muito duro, friável, plástico, muito pegajoso; transição gradual e plana, bonecas de sílex: muito pouco, pequeno $(8 \mathrm{~mm})$, duro, predominam as irregulares, subarredondadas, mamilares, fragmentos angulres rosado (5YR 8/4, seco), algumas bonecas têm manchas pretas (5YR 2/1, seco e quebradas) e presença de carbono vegetal; nódulos: pouco, pequeno $(3 \mathrm{~mm})$, duro, arredondado, preto, ferromanganífero (reage à $\mathrm{H}_{2} \mathrm{O} 2$ ), poros muito pequeno comum; raízes muitas.

AE - $30-45 \mathrm{~cm}$; bruno-avermelhado-escuro a bruno-escuro (5YR 3/4, úmido e 7,5YR 4/4, úmido amassado), bruno-avermelhado a bruno-forte (5YR 4/4, seco e 7,5YR 5/6, seco triturado); franco argiloso; moderada média blocos subangulares, muito duro, firme, plástico, muito pegajoso; transição clara e plana; bonecas de sílex : muito pouco, pequeno $(4 \mathrm{~mm})$, duro, irregulares, mamilares, subarredondadas a bem arredondadas, maiormente cobertas com material preto (5YR 2/1, seco) se intemperizando, atingem aparência de nódulos ferromanganíferos; nódulos: da cor geralmente vermelho-amarelado a rosado (5YR $5 / 6$, seco e 5 YR $8 / 4$, quebradas), muito pouco, pequeno $(3 \mathrm{~mm})$, duro, bem arredondado, preto, reage à $\mathrm{H}_{2} \mathrm{O}_{2}$; poros muito pequeno e comum; raizes muitas.

EB - 45 - $60 \mathrm{~cm}$; bruno-avermelhado-escuro (5YR 3/4, úmido e úmido amassado) a bruno-forte (5YR 4/6, seco e 7,5YR 5/6, seco triturado); argila; moderada média e grande blocos subangulares; duro, firme, muito plástico, muito pegajoso; transição gradual e plana; bonecas de sílex: pouco, pequeno (4 mm) com fragmentos pequenos de material rico em sílica, duro, mamilares, arredondadas, algumas com plaquetas de sílica intemperizada, vermelho-amarelado e cinzento (5YR 6/4, seco e 5YR 5/1, quebradas); nódulos: muito pouco, pequeno (4 mm), duro, arredondado, preto, reage á água oxigenada ( Fe-Mn); poros muito pequeno comum; raízes comum.

Bt1 - 60 - $110 \mathrm{~cm}$; bruno-avermelhado-escuro a bruno-escuro (2,5YR 3/4, úmido e 7,5YR 4/4, úmido amassado), vermelho-escuro a bruno-escuro (2,5YR 3/6, seco e 7,5YR 4/4, seco triturado), com micronódulos preto (7,5YR 2/0) menores de $2 \mathrm{~mm}$ misturados com o solo peneirado; muito argiloso; moderada grande e média prismática que se desfaz em blocos subangulares; muito duro, firme, ligeiramente plástico, pegajoso; transição difusa e plana; bonecas de sílex: pouco, grande $(1,5 \mathrm{~cm}) \mathrm{e}$ pequeno $(3 \mathrm{~mm})$, duro, subarredondadas, achatadas, mamilares e bem arredondadas as pequenas, com fragmentos de sílica que variam de 4 a $15 \mathrm{~mm}$ de comprimento, rosado a branco (5YR 8/4, seco e 7,5YR 8/0, quebradas); nódulos: muito pouco, pequeno (4 mm), duro, arredondado, preto, $\mathrm{Fe}-\mathrm{Mn}$, reage à $\mathrm{H}_{2} \mathrm{O}_{2}$; porosidade fissural; raízes poucas; com cerosidade comum e contínua. 
Bt2g - 110 - $140 \mathrm{~cm}$; bruno-avermelhado-escuro (2,5YR 3/4, úmido e 7,5YR 4/4, úmido amassado) e pequenas partículas rosado (7,5YR 7/4, úmido amassado), cores variegadas: vermelho escuro a vermelho acinzentado a vermelho (2,5YR 3/6, seco-70\%, 2,5YR 5/2, seco-25\%, 2,5YR 4/8-5\%) a bruno (7,5YR 5/4, seco triturado); intenso hidromorfismo; muito argiloso; moderada grande prismática; muito duro, firme, muito plástico, muito pegajoso; transição difusa e plana; bonecas de sílex: pouco, grande $(1 \mathrm{~cm})$ e pequeno $(3 \mathrm{~mm}$ ), misturadas com fragmentos de sílica, angulares de $2,5 \mathrm{~cm}$ de comprimento e $6 \mathrm{~mm}$ de espessura; as bonecas e os torrões estão manchados da cor preto; nódulos: freqüente com maior quantidade que no Bt1, pequeno $(4 \mathrm{~mm})$, duro, arredondado, preto, Fe-Mn, reage à $\mathrm{H}_{2} \mathrm{O}_{2}$; porosidade fissural; poros pequeno comum; raízes poucas, com cerosidade abundante, comum e contínua.

(BCg1) - 140 - $160 \mathrm{~cm}$; vermelho-amarelado a bruno-escuro (5YR 4/6, úmido e 7,5YR 4/4, úmido amassado), bruno-avermelhado com manchas bruno-avermelhado-escuro e bruno-avermelhado-claro (5YR 5/3, seco-40\%; 5YR 2/2, seco-30\% e 5YR 6/4, seco-30\%) a amarelado-avermelhado (7,5YR 6/6, seco triturado) com pontos vermelho (10R 5/6, úmido amassado), intenso hidromorfismo; muito argiloso, muito cascalhenta; moderada pequena blocos subangulares com lâminas de sílica, muito duro, friável, muito plástico, muito pegajoso; transição abrupta e plana; bonecas de sílex: muito freqüente, predominantemente grande $(3 \mathrm{~cm})$ e pequeno $(4 \mathrm{~mm})$, duro, arredondada, achatada, mamilares, bem arredondada, inseridas em camadas de sílica plano-paralelas de $3 \mathrm{~mm}$ de espessura, rosado a cinzentomuito escuro (5YR 8/3, seco e 7,5YR 3/0, quebradas) e vermelho (10R 4/6, seco); nódulos: pouco, pequeno $(4 \mathrm{~mm})$, alguns até $1 \mathrm{~mm}$ no solo peneirado, duro, arredondado, preto, Fe-Mn; concentrações nodulares com manchas pretas $\left(60 \%\right.$ da matriz do solo) reage à $\mathrm{H}_{2} \mathrm{O}_{2}$; poros pequeno comum; raízes raras; cerosidade fraca, pouca e descontínua.

C1g - 160 - 175 cm; bruno-avermelhado-escuro e preto (5YR 3/4- 50\% e 5YR 2/1-50\%, úmido, brunoamarelado-escuro (10YR 3/4, úmido amassado), com muitos micronódulos preto (10YR 2/1, úmido amassado), vermelho-amarelado-acinzentado-muito escuro (5YR 5/8- 50\% e 5YR 3/1- 50\%, seco) a bruno-escuro (10YR 4/3, seco triturado); intenso hidromorfismo; muito argiloso, com cascalho; fraca muito pequena e pequena blocos subangulares; ligeiramente duro, muito friável, plástico, ligeiramente pegajoso; transição abrupta e plana; bonecas de sílex: pouco, pequeno $(4 \mathrm{~mm})$ e grande $(2 \mathrm{~cm})$, bem arredondadas, manchadas da cor preta, mamilares, com fragmentos de sílica intemperizada. Todo o material têm a maior concentração de manchas e nódulos: freqüente, pequeno $(3,5 \mathrm{~mm})$, ligeiramente duro, arredondado e formando manchas ou domínios pretos na matriz do solo, Fe-Mn, reage violentamente à água oxigenada, poros pequeno pouco; raízes raras. 
C2 - 175 - $190 \mathrm{~cm}$; bruno-escuro a bruno-amarelado (7,5YR 4/4, úmido e 10YR 5/8, úmido amassado) com pouco pontos preto e vermelho (10YR 2/1,7,5R 4/6, úmido amassado), bruno-claro a amarelo (7,5YR 6/4, seco e 10YR 7/6, seco triturado); argila, muito cascalhenta; moderada e fraca média e pequena laminar que se desfaz em blocos suabangulares; ligeiramente duro, firme, muito plástico, muito pegajoso; transição abrupta e plana; bonecas de sílex: freqüente, as grandes com $2 \mathrm{~cm}$ e as pequenas com $5 \mathrm{~mm}$ de diâmetro, duro, bem arredondadas, ligeiramente achatadas, com manchas pretas (menores que $\mathrm{Clg}$, Fe-Mn; o material laminar plano-paralelo está intemperizado-se; as bonecas apresentam cores variadas; rosado a bruno-claro (7,5YR 7/4, seco e 7,5YR 6/4, quebradas), manchas preto (2/0, seco) e fragmentos vermelho (10R 4/6, seco); nódulos: pouco $(15 \%)$, pequeno $(3 \mathrm{~mm})$, duro, irregulares, maioria subarredondados, com domínios manchados da cor preta, similares ao material nodular; poros muito pequeno pouco; sem raízes.

C3 - 190 - $207 \mathrm{~cm}$; bruno-avermelhado e bruno-avermelhado-escuro (5YR 4/4- 60\% e 5YR 3/4- 40\%, úmido) a bruno-amarelado (10YR 5/8, úmido amassado) com pontos vermelho-acinzentado 7,5YR 4/4, úmido amassado), rosado a bruno-amarelado (5YR 7/4-60\% e 5YR 5/8- 40\%, seco) a bruno -amareladoclaro (10YR 6/4, seco triturado); argila, muito cascalhenta; moderada média blocos subangulares; muito duro, firme, muito plástico, muito pegajoso; transição clara e plana; bonecas de sílex: freqüente, com predomínio das grandes $(2 \mathrm{~cm})$, e as mais pequenas têm $3 \mathrm{~mm}$, duro, de formas variadas similares a $\mathrm{C}$, com manchas pretas (40\%) do material do solo, mesmo assim os estratos laminares plano-paralelos de argilitos. Os fragmentos de sílica atingem $7 \mathrm{~mm}$ de espessura com manchas pretas a rosado (5YR 2/1 e $5 Y R$ 7/4, seco) a cinzento e bruno-bruno-avermelhado-escuro (5YR 6/1 e 5YR 2/2, seco- quebradas); nódulos: muito pouco geralmente $<2 \mathrm{~mm}$ misturados com o solo peneirado, preto (10YR $2 / 1$, úmido amassado); poros muito pequeno, pouco; sem raízes.

C4 - 207 - $215 \mathrm{~cm}$; vermelho-amarelado a preto (5YR 4/8- 60\% e 5YR 2/1- 40\%, úmido) a brunoavermelhado-escuro (10YR 3/4, úmido amassado), com abundantes micronódulos bruno-muito escuro (10YR 2/2, úmido amassado), vermelho-amarelado e bruno-avermelhado-escuro (5YR 4/6- 60\% e 5YR $2 / 240 \%$, seco) a bruno-escuro (10YR 4/3, seco triturado); muito argiloso; moderada grande blocos subangulares; muito duro, firme, muito plástico, pegajoso; transição clara e plana; bonecas de sílex: pouco, pequena ( $5 \mathrm{~mm}$ ), amarelo-avermelhado a bruno-escuro (7.5YR 7/6, seco e 7,5YR 3/2, quebradas); nódulos: muito pouco, pequeno (4 mm), duro. arredondado, preto, Fe-Mn, reage violentamente à $\mathrm{H}_{2} \mathrm{O}_{2}$; poros muito pequeno; sem raízes. 
+ $215 \mathrm{~cm}$; Lage de sílex; o material rochoso está se intemperizando; bruno-amarelado e brunoavermelhado-escuro (10YR 5/6- 50\% e 2,5YR 3/4 -50\%, úmido) a amarelo e bruno-avermelhado-escuro (10YR 7/6- 50\% e 2,5YR 3/4 -50\%, seco); constitui uma camada impermeável.

\section{PERFIL T3}

DATA- $3 / 6 / 1996$.

CLASSIFICAÇÃO: Podzólico Vermelho Amarelo Ta eutrófico A Cherenozêmico, textura argilosas/muito argilosa.

LOCALIZAÇÃO- Arraial de São Bento-Município de Saltinho, SP- Brasil.

SITUAÇÀO, DECLIVE E COBERTURA VEGETAL SOBRE O PERFIL- Trincheira situada no terço médio da encosta, com $4 \%$ de declive, sob cultura de cana-de-açúcar.

ALTITUDE- 530 metros.

LITOLOGIA E CRONOLOGIA-Sedimentos da formação Irati, Permiano- Era Paleozóica.

MATERIAL ORIGINÁRIO- Produtos do intemperismo de camadas plano-paralelo de sílica, argilitos e calcário dolomítico.

PEDREGOSIDADE- Não pedregosa no primeiro metro de profundidade e muito cascalhenta na camada inferior.

ROCHOSIDADE- Não rochosa.

RELEVO LOCAL- Ligeiramente plano a suave ondulado.

RELEVO REGIONAL- Ondulado.

EROSÃO- Não aparente.

DRENAGEM- Moderadamente drenado a imperfeitamente drenado em função da profundidade.

VEGETAÇÃO PRIMÁRIA- Floresta latifoliada tropical.

USO ATUAL- Cana-de-açúcar.

CLIMA- Mesotérmico úmido subtropical da classificação de Köppen.

REGIMES DE UMIDADE E TEMPERATURA DO SOLO- "Udic e Hyperthermic" respectivamente.

\section{DESCRIÇÃO MORFOLÓGICA}

Ap - 0 - $25 \mathrm{~cm}$; bruno-escuro (7,5YR 3/2, úmido e úmido amassado) a bruno-escuro e bruno-claro (7,5YR 4/4 -70\% e 7,5YR 6/4- 25\%, seco) e pontos preto $2 / 0-5 \%$, seco) a bruno $(7,5 \mathrm{YR} 5 / 4$, seco triturado); argila; moderada grande blocos subangulares; muito duro, firme, plástico, pegajoso; transição gradual e plana; bonecas de silex: muito pouco, pequeno $(4 \mathrm{~mm})$, arredondadas, bruno a branco (10YR 
5/3, seco e 10YR 8/1, quebradas); nódulos: pouco, pequeno (3 mm), duro, arredondado, preto, efervescem à $\mathrm{H}_{2} \mathrm{O}_{2}, \mathrm{Fe}-\mathrm{Mn}$; poros pequeno pouco; raízes muitas.

AE - 25 - 38 cm; bruno-escuro (7,5YR 4/2, úmido e 7,5YR 3/2, úmido amassado), bruno e bruno-escuro (7,5YR 5/4 -70\% e 7,5YR 4/4- 30\%, seco) a bruno (7,5YR 5/4, seco triturado); argila; moderada grande blocos subangulares muito duro, muito pegajoso, muito plástico, transição gradual e plana; bonecas de sílex: muito pouco, pequeno $(4 \mathrm{~mm})$, do mesmo tamanho que os nódulos, intemperizadas, macio e duro, subarredondadas, bruno-amarelado-claro (10YR 5/3, seco e 10YR 6/4, quebradas); nódulos: muito pouco, muito pequeno ( $3 \mathrm{~mm}$ ), duro, arredondado, preto, $\mathrm{Fe}-\mathrm{Mn}$; poros muito pequeno pouco; raízes comum.

E - 38 - $50 \mathrm{~cm}$; bruno-amarelado-escuro a bruno-escuro (10YR 4/4, úmido e 7,5YR 4/4, úmido amassado), com poucos pontos vermelho (2,5YR 4/8, úmido amassado, bruno-amarelado-claro a brunoamarelado-escuro (10YR 6/4 - 60\% e 10YR 3/4 -40\%, seco) a bruno (7,5YR 5/4, seco triturado); torrões manchados da cor preta (2/0, úmido) e vermelho-amarelado (5YR 5/8, úmido); argila; moderada pequena e grande blocos subangulares; muito duro, friável, muito plástico, muito pegajoso; transição clara e plana; bonecas de sílex: pouco, pequeno $(5 \mathrm{~mm})$, duro, arredondadas, mamilares, bruno-amarelado a bruno-claro (10YR 5/8, seco e 7,5YR 6/4, quebradas); outras intemperizadas são da cor preta (2/0, seco); nódulos: muito pouco, pequeno ( $5 \mathrm{~mm})$, duro, preto, arredondado, $\mathrm{Fe}-\mathrm{Mn}$; poros pequeno pouco; raízes comum.

Btgv1 - 50 - 100 cm; bruno-avermelhado-escuro e vermelho-escuro (5YR 3/4- 80\% e 2,5YR 3/6- 20\%, úmido) a bruno-escuro e pouco pontos preto (7,5YR $3 / 2$ e 2/0, úmido amassado), vermelho-amarelado $\mathrm{e}$ vermelho-escuro (7,5YR 4/8- 80\% e 2,5YR 3/6- 20\%, seco) a bruno-escuro (7,5YR 4/4, seco triturado); muito argiloso, muito cascalhenta; moderada grande e média prismática que se desfaz em blocos subangulers; com cerosidade comum e contínua; muito duro, firme, muito plástico, muito pegajoso; transição clara e plana; bonecas de sílex: pouco, pequeno $(3 \mathrm{~mm})$, duro, subarredondadas, mamilares; fragmentos de sílica de $5 \mathrm{~mm}$ de espessura, amarelo e branco (10R 7/6, seco e 10YR 8/1, quebradas), outras são preto e bruno-vermelho-escuro (5YR 2/1 e 5YR 3/4. seco) devido ao intemperismo; nódulos: semelhantes ao horizonte E; porosidade fissural; raízes poucas. com características vérticas e slickensides pouco.

Btgv2 - 100 - $165 \mathrm{~cm}$ : bruno, bruno-amarelado-escuro e preto (10YR 5/3-60\%, 5YR 3/3-30\% e 5YR 2/1- 10\%, úmido) a vermelho-amarelado com pontos vermelho (5YR 4/6 e 2,5YR 4/8, úmido amassado), bruno-claro-acinzentado. bruno-amarelado e bruno-avermelhado-escuro (10YR 6/3-60\%, 5YR 4/3-30\% e 5 YR 2/2- 10\%, seco) a bruno-avermelhado-claro (5YR 6/4, seco triturado); muito argiloso, muito 
cascalhenta; moderada grande e média prismática que se desfaz em blocos subangulares; com cerosidade; muito duro, firme, muito plástico, muito pegajoso; transição gradual plana; bonecas de sílex: muito freqüente (as grandes atingem $2 \mathrm{~cm}$ e as pequenas $4,5 \mathrm{~mm}$ de diâmetro); duro, bem arredondadas, subarredondadas-achatadas, mamilares, bruno-avermelhado-claro a preto (5YR 6/3, seco e 5YR 2/1, quebradas), com fragmentos manchados bruno-avermelhado-escuro (5YR 2/2, seco). Os fragmentos de sílica estão localizados em camadas plano-paralelas $(5 \mathrm{~mm})$, com manchas pretas, a aparência geral é de um B gleizado em processo de oxirredução; nódulos: muito pouco, pequeno $(5 \mathrm{~mm})$, duro, preto, arredondado, Fe-Mn; porosidade fissural; raízes poucas; com características vérticas e slickensides pouco.

\section{PERFIL T4}

DATA- 5 / 61996.

CLASSIFICAÇÃO: Planossolo Ta distrófico A moderado, textura argilosa/muito argilosa.

LOCALIZAÇÃO- Arraial de São Bento - Município de Saltinho, SP- Brasil.

SITUAÇÀO, DECLIVE E COBERTURA VEGETAL- Trincheira situada na base da encosta, em posição localmente rebaixada da microbacia com $3 \%$ de declive, sob cultura de cana-de-açúcar.

ALTITUDE- 530 metros.

LITOLOGIA E CRONOLOGIA- Sedimentos da formação Irati, Permiano- Era Paleozóica.

MATERIAL ORIGINÁRIO- Produtos do intemperismo de camadas plano-paralelas de sílica, argilitos e calcário dolomítico.

PEDREGOSIDADE- Não pedregosa, mas com cascalho a $2 \mathrm{~m}$ de profundidade.

ROCHOSIDADE- Não rochosa.

RELEVO LOCAL- Deprimido em forma de dolina.

RELEVO REGIONAL- Ondulado.

EROSÃO- Não aparente.

DRENAGEM- Moderadamente drenado até $50 \mathrm{~cm}$ e imperfeitamente drenado a maior profundidade.

VEGETAÇÃO PRIMÁRIA- Floresta latifoliada tropical.

USO ATUAL- Cana-de-açúcar.

CLIMA- Mesotérmico úmido subtropical da classificação de Kóppen.

REGIMES DE UMIDADE E TEMPERATURA DO SOLO- "Aquic e Hyperthermic” respectivamente. OBSERVAÇÕES: Pontuações de material plíntico no horizonte E e Btl, pequenas concentrações de material do Bt no horizonte $\mathrm{E}$. 


\section{DESCRIÇÃO MORFOLÓGICA}

Ap - 0 - $32 \mathrm{~cm}$; bruno-escuro e bruno-amarelado-escuro (10YR 4/3- 80\% e 10YR 3/4- 20\%, úmido) a bruno-escuro (10YR 3/3, úmido amassado), bruno-claro-acinzentado e bruno-escuro (10YR 6/3- 80\% e 10YR 4/3- 20\%, seco), com pontos preto (10YR 2/1, seco) e bruno-acinzentado (10YR 5/2, seco triturado); argila; moderada grande blocos subangulares que se desfaz em forte pequena granular; muito duro, firme, muito plástico, muito pegajoso; transição gradual e plana; bonecas de sílex: poucas só foi encontrado um fragmento de sílica de $1,5 \mathrm{~cm}$ de comprimento; nódulos: muito pouco, pequeno (4 $\mathrm{mm}$ ), subarredondado, irregulares, duro, Fe-Mn; poros muito pequeno pouco; raízes muitas; o solo reage à $\mathrm{H}_{2} \mathrm{O}_{2 .}$

E - 32 - $58 \mathrm{~cm}$; bruno-amarelado-escuro (10YR 4/4/, úmido) a bruno-escuro com pontos vermelho (10YR 4/3 e 2,5YR 4/8, úmido amassado), cinzento-bruno-claro e bruno-escuro (10YR 6/2-80\% e 10YR 4/3- 20\%, seco) a cinzento-claro (10YR 7/2, seco triturado); muito argiloso; fraca média blocos subangulares que se desfaz em moderada muito fina granular; duro, firme, plástico, pegajoso; transição abrupta e plana; bonecas de sílex: muito raras, pequeno $(6 \mathrm{~mm})$, macio-duro, irregulares, oxidadas, brunoavermelhado-claro, vermelho-amarelado e preto (5YR 6/3, 5YR 5/8 e 5YR 2/1, seco); nódulos: muito pouco (em quantidade menor que no Ap), pequeno $(3 \mathrm{~mm})$, duro, subarredondado, irregulares, intemperizados, preto, Fe-Mn; poros muito pequeno pouco; o solo não reage à $\mathrm{H}_{2} \mathrm{O}_{2}$.

Btgv 1 - 58 - $80 \mathrm{~cm}$; bruno-escuro e bruno-amarelado-escuro (10YR 4/3- 50\% e 10YR 3/4 -50\%, úmido), bruno-amarelado-escuro com partículas vermelho-escuro (10YR 3/4 e 2,5YR 3/6, úmido amassado), bruno-claro-acinzentado a bruno-amarelado-escuro (10YR 6/3-50\% e 10YR 4/4- 50\%, seco) e cinzentobruno-claro (10YR 6/2, seco triturado); muito argiloso; moderada grande prismática, que se desfaz em moderada média e pequena blocos subangulares; com cerosidade comum, abundante e contínua; ligeiramente duro, firme, muito plástico, muito pegajoso; transição gradual e plana; bonecas de sílex: pouco, pequeno $(3 \mathrm{~mm})$ e grande $(3 \mathrm{~cm})$, ligeiramente duro e duro, subarredondadas, bruno muito claroacinzentado e bruno-amarelado-escuro (10YR 7:3, seco e 10YR 4/4, quebradas), com fragmentos muito pouco, vermelho (2,5YR 4/8, seco), cinzento muito escuro (2,5YR 3/0, seco), pequeno (6 mm), angulares até de $2 \mathrm{~cm}$ de comprimento; porosidade fissural; raízes comum; com características vérticas e slickensides pouco. 
Btgv2 - 80 - $137 \mathrm{~cm}$; bruno-acinzentado- muito escuro e bruno-avermelhado-escuro (10YR 3/2- 60\% e 2,5YR 3/4- 40\%, úmido) a bruno-avermelhado-escuro e partículas vermelho (10YR 3/4 e 2,5YR 4/6, úmido amassado), bruno-acinzentado e vermelho-escuro (10YR 5/2-60\% e 2,5YR 3/6- 40\%, seco) a bruno (10YR 5/3, seco triturado); muito argiloso; moderada muito grande prismática que se desfaz em moderada média blocos subangulares; com cerosidade comum, abundante e contínua; extremadamente duro, friável, muito plástico, muito pegajoso; transição difusa e plana; bonecas de sílex: muito raras (total

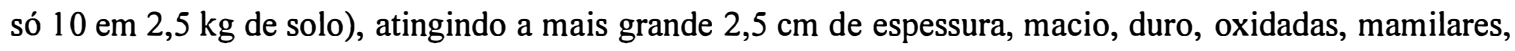
bem arredondadas, achatadas e as mais pequenas de $3 \mathrm{~mm}$ de diâmetro, bruno-claro-acinzentado, brunoescuro e bruno-muito claro-acinzentado (10YR 6/3, seco e 10YR 4/3, 10YR 7/4, quebradas); nódulos: muito pouco, pequeno $(4 \mathrm{~mm})$, arredondado e subarredondado, preto ao quebrar-lhes, tendo cor superficial do solo (Fe-Mn), dando aparência que as bonecas pequenas muito intemperizadas convertemse em nódulos preto; porosidade fissural; raízes poucas; características vérticas muito evidentes, com slickensides comum e superfícies alisada e lustrosas.

Btgv3 - 137 - $175 \mathrm{~cm}$; bruno-acinzentado-muito-escuro, bruno-amarelado-escuro e bruno-escuro (10YR 3/2- 70\%, 10YR 4/4- 20\% e 10YR 3/3-10\%, úmido), bruno-acinzentado-escuro com partículas brunoamarelado-escuro abundantes (10YR 4/2 e 10YR 3/4, úmido amassado), cinzento-brunado-claro e brunoamarelado-escuro, com pontos preto (10YR 6/2- 70\%, 10YR 4/4- 30\% e 10YR 2/1, seco) a brunoacinzentado (10YR 5/2, seco triturado); muito argiloso; moderada grande prismática ou em forma de cunha com fendilhamento inclinado, que se desfaz em moderada média e grande blocos subangulares; com cerosidade comum e contínua: extremadamente duro, firme, muito plástico, muito pegajoso; transição difusa e plana; bonecas de sílex: muito raras, fragmentos intemperizados de sílica bruno amarelado-escuro (2,5YR 2/4), com aparência de se transformar em nódulos, têm cores variadas: brunoescuro, branco e bruno-amarelado-escuro (10YR 3/3, 10YR 8/2 e 10YR 3/4, seco-quebradas); nódulos: muito pouco, pequeno ( $3 \mathrm{~mm}$ ), os mais pequenos são confundidos com a matriz do solo, subarredondado quase irregulares, macio- duro, Fe-Mn, porosidade fissural; raizes raras; com características vérticas e slickensides pouco.

C1g - 175 - $193 \mathrm{~cm}$; preto, bruno-acinzentado-muito escuro e bruno-amarelado-escuro (10YR 2/1- 70\%, 10YR 3/2 - 20\% e 10YR 4/4- 10\%, úmido) a bruno-muito-escuro e partículas amarelo (10YR $2 / 2$ e $10 \mathrm{YR}$ 8/6, úmido amassado), preto, bruno-escuro e bruno-amarelado (10YR 2/1- 70\%, 10YR 3/3-20\% e 10YR 5/8- $10 \%$. seco) a bruno-escuro (1OYR 3/3, seco triturado); muito argiloso; moderada muito pequena prismática que se desfaz em moderada muito pequena laminar; duro, firme, muito plástico, muito pegajoso: transição abrupta e plana: fragmentos de camadas de sílica de $5 \mathrm{~mm}$ de espessura; bonecas de 
sílex: pouco, pequeno (variando de $3 \mathrm{~mm}$ até $1 \mathrm{~cm}$ ), duro, as lâminas apresentam cores bruno-amareladoescuro a bruno-muito escuro (10YR 4/4 e 10YR 2/2, seco); nódulos: freqüentes (30\%), pequeno $(4,5$ $\mathrm{mm}$ ), subarredondado, outros irregulares intemperizados por hidromorfismo, Fe-Mn, reage muito violentamente á $\mathrm{H}_{2} \mathrm{O}_{2}$; poros muito pequeno pouco; raízes raras; não apresenta características vérticas evidentes.

C2 - 193 - 214 cm; amarelo-claro-acinzentado e cinzento-oliváceo (5Y 7/4- 60\% e 5Y

4/4 -40\%, úmido), a oliva-claro-acinzentado com raras partículas amarelo-oliváceo (5Y 6/3 e $5 \mathrm{Y} 6 / 8$, úmido amassado), amarelo-claro-acinzentado e cinzento-oliváceo (5Y 8/3- estrato e 5Y 5/2- solo, seco) a cinzento-claro (5Y 7/2, seco triturado) argila com cascalho; fraca média laminar; ligeiramente duro, firme, muito plástico, muito pegajoso; transição abrupta e plana; bonecas de sílex: muito raras, grande $(2,5 \mathrm{~cm})$ sendo que as mais pequenas têm $6 \mathrm{~mm}$, duro, quase irregulares, poucas bem arredondadas, misturadas com camadas laminares plano-paralelas de sílica de $6 \mathrm{~mm}$ de espessura $(<1 \mathrm{~cm})$; quase não reage á $\mathrm{H}_{2} \mathrm{O}_{2}$, mas sim os domínios preto manganíferos; não há nódulos; poros pequeno pouco; sem raízes.

$+214 \mathrm{~cm}$; Lage de sílex, duro sendo a base impermeável como causa do hidromorfismo destes solos. 


\section{A P Ê N D I C E 2}

Cálculos estatísticos da distribuição granulométrica das areias 
mariano

Arquivo de entrada MCMT1.DAT

Arquivo de saida MCMT1.OUT

$13-11-1998 \quad 13: 42: 06$

\begin{tabular}{|c|c|c|c|c|c|c|c|}
\hline $0-30 \mathrm{~cm}$ & & & & $133-150 \mathrm{~cm}$ & & & \\
\hline intervalo phi & valor abs & orel & $\%$ cum & intervalo phi & valor abs & $\%$ rel & $\%$ cum \\
\hline-1.00 a $\quad 0.00$ & 1.00 & 1 & 1 & -1.00 a $\quad 0.00$ & 1.00 & 8 & 8 \\
\hline 0.00 a 1.00 & 2.00 & 2 & 3 & 0.00 a 1.00 & 2.00 & 15 & 23 \\
\hline 1.00 a 2.00 & 4.00 & 4 & 6 & $1.00 \mathrm{a} \quad 2.00$ & 2.00 & 15 & 38 \\
\hline 2.00 a 3.25 & 9.00 & 8 & 14 & $2.00 \mathrm{a} \quad 3.25$ & 5.00 & 38 & 77 \\
\hline 3.25 a 4.24 & 97.00 & 86 & 100 & 3.25 a 4.24 & 3.00 & 23 & 100 \\
\hline
\end{tabular}

Interpretacao do grafico (segundo Folk e Ward, 1957): Interpretacao do grafico (segundo Folk e Ward, 1957): media grafica 3.564

desvio padrao 0.496

assimetria $\quad-0.294$ assimetria negativa (grosseiros)

curtose +2.425

bem selecionado

media grafica 2.130

desvio padrao 1.316 pobremente selecionado

assimetria $\quad-0.271$ assimetria negativa (grosseiros)

curtose $\quad+0.826$ platicurtico

$30-83 \mathrm{~cm}$

intervalo phi

-1.00 a 0.00

0.00 a 1.00

1.00 a 2.00

2.00 a 3.25

3.25 a 4.24

valor abs \%rel \%cum

$\begin{array}{rrr}1.00 & 8 & 8 \\ 0.00 & 0 & 8 \\ 2.00 & 17 & 25 \\ 6.00 & 50 & 75 \\ 3.00 & 25 & 100\end{array}$

Interpretacao do grafico (segundo Folk e Ward, 1957): media grafica 2.543

desvio padrao 1.090

assimetria $\quad-0.271$

curtose pobremente selecionado

assimetria negativa (grosseiros)

leptocurtico 150-165m

intervalo phi

-1.00 a 0.00

0.00 a 1.00

1.00 a 2.00

2.00 a 3.25

3.25 a 4.24 valor abs \%rel \%cum

$3.00 \quad 25 \quad 25$

$1.00 \quad 8 \quad 33$

$2.00 \quad 17 \quad 50$

$\begin{array}{lll}4.00 & 33 & 83\end{array}$

$2.00 \quad 17 \quad 100$

Interopretacao do grafico (segundo Folk e Ward, 1957) : media grafica 1.695

desvio padrao 1.525 pobremente selecionado

assifietria $\quad-0.228$ assimetria negativa (grosseiros)

curtose t0.616 muito platicurtico

$83-133 \mathrm{~cm}$

intervalo phi valor abs srel "cum

-1.00 a 0.00

0.00 a 1.00

1.00 a 2.00

2.00 a 3.25

3.25 a 4.24

Interpretacao do grafico (segundo folk e Hard, 1957) : media grafica 2.330

desvio padrao $\quad 1.200$

assimetria $\quad-0.289$

curtose

$\begin{array}{rrr}1.00 & 8 & 8 \\ 1.00 & 8 & 15 \\ 2.00 & 15 & 31 \\ 6.00 & 46 & 77 \\ 3.00 & 23 & 100\end{array}$

$+1.104$ robremente selecionado

assimetria negativa (grosseiros)

nesocurtico
$165-180 \mathrm{~cm}$

intervalo phi

$-1.00 \div 0.00$

$0.00 \approx 1.00$

$1.00 \approx 2.00$

$2.00 \div 3.25$

$3.2 \vdots 3 \quad 4.24$

$\begin{array}{rrr}\text { valor abs } & \text { irel } & \text { icum } \\ 0.00 & 0 & 0 \\ 1.00 & 14 & 14 \\ 1.00 & 14 & 29 \\ 3.00 & 43 & 71 \\ 2.00 & 29 & 100\end{array}$

Interoretacao do grafico (segundo Folk e Hard, 1957): media jrafica 2.428

desvi: padrao 1.086

assicerria -10.254

curtose $\quad+0.877$

pobremente selecionado assimetria negativa (grosseiros) platicurtico 
$180-211 \mathrm{~cm}$

$\begin{array}{rrrrr}\text { intervalo phi } & \text { valor abs } & \text { \%rel } & \text { \%cum } \\ -1.00 \text { a } & 0.00 & 2.00 & 20 & 20 \\ 0.00 \text { a } & 1.00 & 2.00 & 20 & 40 \\ 1.00 \text { a } & 2.00 & 1.00 & 10 & 50 \\ 2.00 \text { a } & 3.25 & 3.00 & 30 & 80 \\ 3.25 \text { a } & 4.24 & 2.00 & 20 & 100\end{array}$

$235-246 \mathrm{~cm}$

\begin{tabular}{rrrrr}
\multicolumn{2}{c}{ intervalo phi } & valor abs & \%rel & \%cum \\
-1.00 a & 0.00 & 0.00 & 0 & 0 \\
$0.00 \mathrm{a}$ & 1.00 & 1.00 & 12 & 12 \\
$1.00 \mathrm{a}$ & 2.00 & 1.00 & 12 & 25 \\
$2.00 \mathrm{a}$ & 3.25 & 3.00 & 38 & 62 \\
$3.25 \mathrm{a}$ & 4.24 & 3.00 & 38 & 100
\end{tabular}

Interpretacao do grafico (segundo Folk e Ward, 1957) : Interpretacao do grafico (segundo Folk e Ward, 1957) : media grafica 1.750 desvio padrao 1.520 assimetria $\quad-0.196$ pobremente selecionado media grafica 2.603 desvio padrao 1.059 curtose $+0.652$ assimetria negativa (grosseiros) assimetria $-0.357$ curtose $+0.949$

pobremente selecionado assimetria mui to negativa (grosseiros: mesocurtico

\section{$211-220 \mathrm{~cm}$}

$\begin{array}{rrrrr}\text { intervalio phi } & \text { valor abs } & \% \text { rel } & \% \text { cum } \\ -1.00 \text { a } & 0.00 & 0.00 & 0 & 0 \\ 0.00 \text { a } & 1.00 & 1.00 & 14 & 14 \\ 1.00 \text { a } & 2.00 & 1.00 & 14 & 29 \\ 2.00 \text { a } & 3.25 & 3.00 & 43 & 71 \\ 3.25 \text { a } & 4.24 & 2.00 & 29 & 100\end{array}$

\section{$246-272 \mathrm{~cm}$}

$\begin{array}{rrrrr}\text { intervalo phi } & \text { valor abs } & \text { \%rel } & \text { \%cum } \\ -1.00 \text { a } & 0.00 & 1.00 & 10 & 10 \\ 0.00 \text { a } & 1.00 & 2.00 & 20 & 30 \\ 1.00 \text { a } & 2.00 & 2.00 & 20 & 50 \\ 2.00 \text { a } & 3.25 & 3.00 & 30 & 80 \\ 3.25 \text { a } & 4.24 & 2.00 & 20 & 100\end{array}$

Interpretacao do grafico (segundo folk e Hard, 1957) : Interpretacao do grafico (segundo Folk e Hard, 1957):

media grafica 2.428

desvio padrao 1.086

assimetria $\quad-0.254$

curtose popremente selecionado assimetria negativa (grosseiros) platicurtico media grafica 1.910

desvio padrao 1.370

$-0.113$

$+0.770$ pobremente selecionado assimetria negativa (grosseiros) platicurtico

\section{$220-235 \mathrm{~cm}$}

$\begin{array}{rrrrr}\text { intervalo phi } & \text { valor abs } & \% \text { irel } & \text { \%cum } \\ -1.00 \text { a } & 0.00 & 1.00 & 20 & 20 \\ 0.00 \text { a } & 1.00 & 1.00 & 20 & 40 \\ 1.00 \text { a } & 2.00 & 1.00 & 20 & 60 \\ 2.00 \text { a } & 3.25 & 1.00 & ? 0 & 80 \\ 3.25 \text { a } & 4.24 & 1.00 & 20 & 100\end{array}$

\section{$272-286 \mathrm{~cm}$}

$\begin{array}{rrrrr}\text { intervalo phi } & \text { valor abs } & \text { orel } & \text { :cum } \\ -1.00 \text { a } & 0.00 & 1.00 & 12 & 12 \\ 0.00 \text { a } & 1.00 & 1.00 & 12 & 25 \\ 1.00 \text { a } & 2.00 & 1.00 & 12 & 38 \\ 2.00 \text { a } & 3.25 & 3.00 & 38 & 75 \\ 3.25 \text { a } & 4.24 & 2.00 & 25 & 100\end{array}$

Interpretacao do grafico (segundo folk e Ward, 1957): Interpretac3o do grafico (segundo folk e ward, 1957):

media grafica 1.583

desvio padrao 1.520 pobremente selecionado

assimetria $\quad+0.064$ aproximadamente simetrica curtose +0.679 olaticurtico media grafica 2.064

desvio padrao 1.413 pobremente selecionado

assimetria $\quad-0.319$ issimetria muito negativa (grosseiros curtose $\quad+0.772$ siaticurico 
mariano

Arquivo de entrada MCMT2.DAT

Arquivo de saida MCMT2.OUT

13-11-1998 13:55:00

$\begin{array}{lrrrr}0-30 \mathrm{~cm} & & & \\ \text { intervalo phi } & \text { valor abs } & \% \text { rel } & \% \text { cum } \\ -1.00 \text { a } & 0.00 & 0.00 & 0 & 0 \\ 0.00 \text { a } & 1.00 & 2.00 & 8 & 8 \\ 1.00 \text { a } & 2.00 & 4.00 & 16 & 24 \\ 2.00 \text { a } & 3.25 & 12.00 & 48 & 72 \\ 3.25 \text { a } & 4.24 & 7.00 & 28 & 100\end{array}$

$60-110 \mathrm{~cm}$

intervalo phi valor abs \%rel \%cum

$\begin{array}{lllll}-1.00 \text { a } & 0.00 & 1.00 & 8 & 8\end{array}$

$\begin{array}{lllll}0.00 \text { a } & 1.00 & 1.00 & 8 & 17\end{array}$

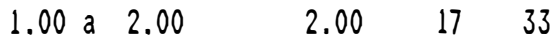

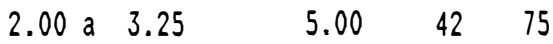

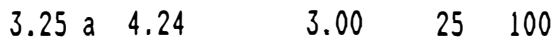

Interpretacao do grafico (segundo Folk e Ward, 1957): Interpretacao do grafico (segundo Folk e Ward, 1957): media grafica 2.585

desvio padrao 0.946

assimetria $\quad-0.204$ assimetria negativa (grosseiros)

media grafica 2.282

desvio padrao 1.253 pobremente selecionado

curtose +1.004

mesocurtico

assimetria $\quad-0.299$

curtose $\quad+0.983$

assimetria negativa (grosseiros) mesocurtico

$30-45 \mathrm{~cm}$

intervalo phi valor abs \%rel scum

-1.00 a 0.00

0.00 a 1.00

1.00 a 2.00

2.00 a 3.25

3.25 a 4.24

$\begin{array}{rrr}1.00 & 3 & 3 \\ 2.00 & 7 & 10 \\ 5.00 & 17 & 28 \\ 13.00 & 45 & 72 \\ 8.00 & 28 & 100\end{array}$

Interpretacao do grafico (segundo Folk e Ward, 1957): media grafica 2.506

desvio padrao 1.042

assimetria $\quad-0.231$

curtose $\quad+0.990$

pobremente selecionado

assimetria negativa (grosseiros)

mesocurtico
$110-140 \mathrm{~cm}$

intervalo phi valor abs \%rel \%cum

$\begin{array}{rrrrr}-1.00 \text { a } & 0.00 & 0.00 & 0 & 0\end{array}$

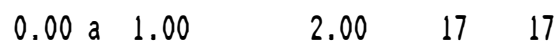

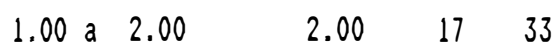

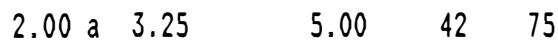

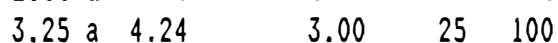

$\begin{array}{rrrrr}45-60 \mathrm{~cm} & & & & \\ \text { intervalo phi } & \text { valor abs } & \% \text { rel } & \% \text { cum } \\ -1.00 \text { a } & 0.00 & 1.00 & 5 & 5 \\ 0.00 \text { a } & 1.00 & 2.00 & 9 & 14 \\ 1.00 \text { a } & 2.00 & 4.00 & 18 & 32 \\ 2.00 \text { a } & 3.25 & 9.00 & 41 & 73 \\ 3.25 \text { a } & 4.24 & 6.00 & 27 & 100\end{array}$

Interpretacao do grafico (segundo Folk e Ward, 1957): nedia grafica 2.384

desvio dadrao $\quad 1.166$

assimetria $\quad-0.262$

curtose

$+0.972$ mesocurtico
$140-160 \mathrm{~cm}$

$\begin{array}{rrrrr}\text { intervalo phi } & \text { valor abs } & \text { "rel } & \text { ocum } \\ -1.00 \text { a } & 0.00 & 2.00 & 17 & 17 \\ 0.00 \text { a } & 1.00 & 3.00 & 25 & 42 \\ 1.00 \text { a } & 2.00 & 2.00 & 17 & 58 \\ 2.00 \text { a } & 3.25 & 3.00 & 25 & 83 \\ 3.25 \text { a } & 4.24 & 2.00 & 17 & 100\end{array}$

Interpretacao do grafico (segundo Folk e Ward, 1957): media grafica 2.302 desvio padrao 1.123 pobremente selecionado assimetria $\quad-0.215$ assimetria negativa (grosseiros) curtose $\quad$ t0.801 platicurtico

Interpretacao do grafico (segundo Folk e Ward, 1957): media grafica 1.583

desvio padrao 1.472 pobremente selecionado assimetria negativa (grosseiros) assimetria +0.067 aproximadamente simetrica

curtose

+0.722 platicurtico 
$160-175 \mathrm{~cm}$

$\begin{array}{rrrrr}\text { intervalo phi } & \text { valor abs } & \text { \%rel } & \text { \%cum } \\ -1.00 \text { a } & 0.00 & 1.00 & 6 & 6 \\ 0.00 \text { a } & 1.00 & 5.00 & 31 & 38 \\ 1.00 \text { a } & 2.00 & 3.00 & 19 & 56 \\ 2.00 \text { a } & 3.25 & 4.00 & 25 & 81 \\ 3.25 \text { a } & 4.24 & 3.00 & 19 & 100\end{array}$

$207-215 \mathrm{~cm}$

\begin{tabular}{rrrrr}
\multicolumn{2}{c}{ intervalo phi } & valor abs & \%rel & :cum \\
-1.00 a & 0.00 & 2.00 & 12 & 12 \\
$0.00 \mathrm{a}$ & 1.00 & 2.00 & 12 & 25 \\
$1.00 \mathrm{a}$ & 2.00 & 3.00 & 19 & 44 \\
$2.00 \mathrm{a}$ & 3.25 & 6.00 & 38 & 81 \\
$3.25 \mathrm{a}$ & 4.24 & 3.00 & 19 & 100
\end{tabular}

Interpretacao do grafico (segundo Folk e Ward, 1957) : media grafica 1.816

desvio padrao 1.310 pobremente selecionado

assimetria +0.117 assimetria positiva (finos)

curtose
$+0.727$
Interpretacao do grafico (segundo Folk e Ward, 1957) : media grafica 1.958

desvio padrao 1.376 pobremente selecionado

assimetria $\quad-0.233$

curtose assimetria negativa (grosseiros)

platicurtico

$175-190 \mathrm{~cm}$

$\begin{array}{rrrrr}\text { intervalo phi } & \text { valor abs } & \text { \%rel } & \text { \%cum } \\ -1.00 \text { a } & 0.00 & 1.00 & 7 & 7 \\ 0.00 \text { a } & 1.00 & 3.00 & 21 & 29 \\ 1.00 \text { a } & 2.00 & 3.00 & 21 & 50 \\ 2.00 \text { a } & 3.25 & 3.00 & 21 & 71 \\ 3.25 \text { a } & 4.24 & 4.00 & 29 & 100\end{array}$

Interpretacao do grafico (segundo Folk e Ward, 1957) :

media grafica 2.006

desvio padrao 1.359 pobremente selecionado

assimetria $\quad-0.039$ aproximadamente simetrica

curtose $\quad$ t0.679 platicurtico

$190-207 \mathrm{~cm}$

$\begin{array}{rrrrr}\text { intervalo phi } & \text { valor abs } & \text { \%rel } & \% \text { cum } \\ -1.00 \text { a } & 0.00 & 1.00 & 8 & 8 \\ 0.00 \text { a } & 1.00 & 3.00 & 25 & 33 \\ 1.00 \text { a } & 2.00 & 2.00 & 17 & 50 \\ 2.00 \text { a } & 3.25 & 4.00 & 33 & 83 \\ 3.25 \text { a } & 4.24 & 2.00 & 17 & 100\end{array}$

Interpretacao so grafico (segundo folk e Naro, 1957) :

media grafica 1.901

desvio padrao 1.321 pobremente selecionado

assimetria $\quad-0.116$ assimetria negativa (grosseiros)

curtose $\quad+0.773$ platicurtico 
mariano

Arquivo de entrada MCMT3.DAT

Arquivo de saida MCMT3.OUT

$13-11-1998 \quad 14: 02: 42$

\begin{tabular}{|c|c|c|c|}
\hline intervalo phi & valor abs & $\%$ rel & \%cum \\
\hline .00 a 0.00 & 1.00 & 3 & 3 \\
\hline 0.00 a 1.00 & 3.00 & 10 & 14 \\
\hline 1.00 a 2.00 & 5.00 & 17 & 31 \\
\hline 2.00 a 3.25 & 12.00 & 41 & 72 \\
\hline 3.25 a 4.24 & 8.00 & 28 & 100 \\
\hline
\end{tabular}

$50-100 \mathrm{~cm}$

Interpretacao do grafico (segundo Folk e Ward, 1957) : Interpretacao do grafico (segundo Folk e Ward, 1957): media grafica 2.401

desvio padrao 1.124

assimetria $\quad-0.252$

pobremente selecionado

- media grafica 2.282

desvio padrao 1.253

intervalo phi valor abs \%rel \%cum

-1.00 a 0.00

$1.00 \quad 8 \quad 8$

0.00 a 1.00

$\begin{array}{lll}1.00 & 8 & 17\end{array}$

1.00 a 2.00

$\begin{array}{lll}2.00 & 17 & 33\end{array}$

2.00 a 3.25

$5.00 \quad 42 \quad 75$

3.25 a 4.24

$3.00 \quad 25 \quad 100$

curtose $\quad+0.908$

assimetria negativa (grosseiros)

assimetria $\quad-0.299$

curtose $\quad+0.983$

pobremente selecionado

assimetria negativa (grosseiros)

mesocurtico

mesocurtico

$\begin{array}{lrrrr}25-38 \mathrm{~cm} & & & & \\ \text { intervalo phi } & \text { valor abs } & \text { \%rel } & \text { \%cum } \\ -1.00 \text { a } & 0.00 & 1.00 & 4 & 4 \\ 0.00 \text { a } & 1.00 & 3.00 & 11 & 14 \\ 1.00 \text { a } & 2.00 & 5.00 & 18 & 32 \\ 2.00 \text { a } & 3.25 & 12.00 & 43 & 75 \\ 3.25 \text { a } & 4.24 & 7.00 & 25 & 100\end{array}$

$100-165 m$

Interpretacao do grafico (segundo Folk e Ward, 1957) : Interpretacao do grafico (segundo Folk e Ward, 1957) : media grafica 2.364

desvio padrao 1.132 pobremente selecionado

assimetria $\quad-0.237$ assimetria negativa (grosseiros)

curtose

$+0.949$

mesocurtico

intervalo phi

-1.00 a 0.00

0.00 a 1.00

1.00 a 2.00

2.00 a 3.25

3.25 a 4.24 valor abs grel :cum

$\begin{array}{lll}1.00 & 8 & 8\end{array}$

$\begin{array}{lll}1.00 & 8 & 17\end{array}$

$2.00 \quad 17 \quad 33$

$5.00 \quad 42 \quad 75$

$3.00 \quad 25 \quad 100$ media grafica 2.282

desvio padrao 1.253

assimetria $\quad-0.299$

pobremente selecionado

curtose $\quad+0.983$

assimetria negativa (grosseiros)

mesocurtico

$38-50 \mathrm{~cm}$

\begin{tabular}{rrrrr}
\multicolumn{2}{c}{ intervalo phi } & valor abs & :rel & \%cum \\
$-1.00 \mathrm{a}$ & 0.00 & 1.00 & 3 & 3 \\
$0.00 \mathrm{a}$ & 1.00 & 4.00 & 13 & 17 \\
$1.00 \mathrm{a}$ & 2.00 & 5.00 & 17 & 33 \\
$2.00 \mathrm{a}$ & 3.25 & 14.00 & 47 & 80 \\
$3.25 \mathrm{a}$ & 4.24 & 6.00 & 20 & 100
\end{tabular}

Interpretacao vo grafico (segundo folk e Ward, 1957):

media grafica 2.246

desvio padrao 1.134 pobremente selecionado

assimetria -0.231 assimetria negativa (grosseiros)

curtose $\quad 20.938$ mesocurtico 
mariano

Arquivo de entrada MCMT4.DAT

Arquivo de saida MCMT4.OUT

13-11-1998 14:07:35

$0-32 \mathrm{~cm}$

intervalo phi

-1.00 a 0.00

0.00 a 1.00

1.00 a 2.00

2.00 a 3.25

3.25 a 4.24 valor abs \%rel \%cum

$\begin{array}{lll}3.00 & 10 \quad 10\end{array}$

$3.00 \quad 10 \quad 19$

$\begin{array}{lll}4.00 & 13 & 32\end{array}$

$\begin{array}{lll}14.00 & 45 & 77\end{array}$

$\begin{array}{lll}7.00 & 23 \quad 100\end{array}$

$80-137 \mathrm{~cm}$

Interpretacao do grafico (segundo Folk e Hard, 1957):

media grafica 2.202

desvio padrao 1.305

assimetria $\quad-0.338$

curtose $\quad+1.012$

pobremente selecionado

assimetria muito negativa (grosseiros)

mesocurtico

intervalo phi

-1.00 a 0.00

0.00 a 1.00

1.00 a 2.00

2.00 a 3.25

3.25 a 4.24

$\begin{array}{rrr}\text { valor abs } & \% \text { rel } & \text { \%cum } \\ 0.00 & 0 & 0 \\ 1.00 & 14 & 14 \\ 1.00 & 14 & 29 \\ 3.00 & 43 & 71 \\ 2.00 & 29 & 100\end{array}$

Interpretacao do grafico (segundo Folk e Ward, 1957) : media grafica 2.428

desvio padrao 1.086

assimetria $\quad-0.254$

curtose $\quad+0.877$

pobremente selecionado

assimetria negativa (grosseiros platicurtico
$32-58 \mathrm{~cm}$

$\begin{array}{rrrrr}\text { intervalo phi } & \text { valor abs } & \% \text { rel } & \% \text { cum } \\ -1.00 \text { a } & 0.00 & 2.00 & 7 & 7 \\ 0.00 \text { a } & 1.00 & 3.00 & 10 & 17 \\ 1.00 \text { a } & 2.00 & 5.00 & 17 & 33 \\ 2.00 \text { a } & 3.25 & 12.00 & 40 & 73 \\ 3.25 \text { a } & 4.24 & 8.00 & 27 & 100\end{array}$

Interpretacao do grafico (segundo Folk e Ward, 1957): media grafica 2.305

desvio padrao 1.250

assimetria $\quad-0.301$

curtose $\quad+0.952$

pobremente selecionado

assimetria muito negativa (grosseiros)

mesocurtico
$137-175 \mathrm{~cm}$

intervalo phi

-1.00 a 0.00

0.00 a 1.00

1.00 a 2.00

2.00 a 3.25

3.25 a 4.24 valor abs \%rel \%cum

$0.00 \quad 0 \quad 0$

$\begin{array}{lll}1.00 & 11 & 11\end{array}$

$2.00 \quad 22 \quad 33$

$\begin{array}{lll}4.00 & 44 \quad 78\end{array}$

$2.00 \quad 22 \quad 100$

Interpretacao do grafico (segundo Folk e Ward, 1957) : media grafica 2.380

desvio padrao 1.007 pobremente selecionado

assimetria $\quad-0.129$

assimetria negativa (grosseircs

curtose

$+0.903$ mesocurtico

$58-80 \mathrm{~cm}$

intervalo phi

-1.00 a 0.00

0.00 a 1.00

1.00 a 2.00

2.00 a 3.25

3.25 a 4.24

$\begin{array}{rrr}\text { valor abs } & \% \text { rel } & \% \text { cum } \\ 0.00 & 0 & 0 \\ 2.00 & 20 & 20 \\ 2.00 & 20 & 40 \\ 4.00 & 40 & 80 \\ 2.00 & 20 & 100\end{array}$

Interpretacao do grafico (segundo Folk e Ward, 1957) : media grafica 2.179

desvio padrao 1.118

assimetria $\quad-0.117$

curtose

$+0.768$

pobremente selecionado

assimetria negativa (grosseiros)

platicurtico

\section{$175-193 \mathrm{~cm}$}

intervalo phi

-1.00 a 0.00

0.00 a 1.00

1.00 a 2.00

2.00 a 3.25

3.25 a 4.24

$\begin{array}{rrr}\text { valor abs } & \text { orel } & \% \text { cum } \\ 3.00 & 17 & 17 \\ 2.00 & 11 & 28 \\ 4.00 & 22 & 50 \\ 5.00 & 28 & 78 \\ 4.00 & 22 & 100\end{array}$

Interpretacao do grafico (segundo Folk e Ward, 1957): nedia grafica 1.787

desvio padrao 1.508

assimetria $\quad-0.174$

pobremente selecionado

curtose

$+0.756$

assimetria negativa (orosseiros b) laticurtico 
$193-214 \mathrm{~cm}$

$\begin{array}{rrrrr}\text { intervalo phi } & \text { valor abs } & \text { \%rel } & \text { \%cum } \\ -1.00 \text { a } & 0.00 & 5.00 & 22 & 22 \\ 0.00 \text { a } & 1.00 & 5.00 & 22 & 43 \\ 1.00 \text { a } & 2.00 & 4.00 & 17 & 61 \\ 2.00 \text { a } & 3.25 & 6.00 & 26 & 87 \\ 3.25 \text { a } & 4.24 & 3.00 & 13 & 100\end{array}$

Interpretacao do grafico (segundo Folk e Ward, 1957) : media grafica 1.433

desvio padrao 1.442 pobremente selecionado assimetria $\quad+0.062$ aproximadamente simetrica curtose to.718 platicurtico 


\section{APÊNDICE 3}

\section{Outras figuras}




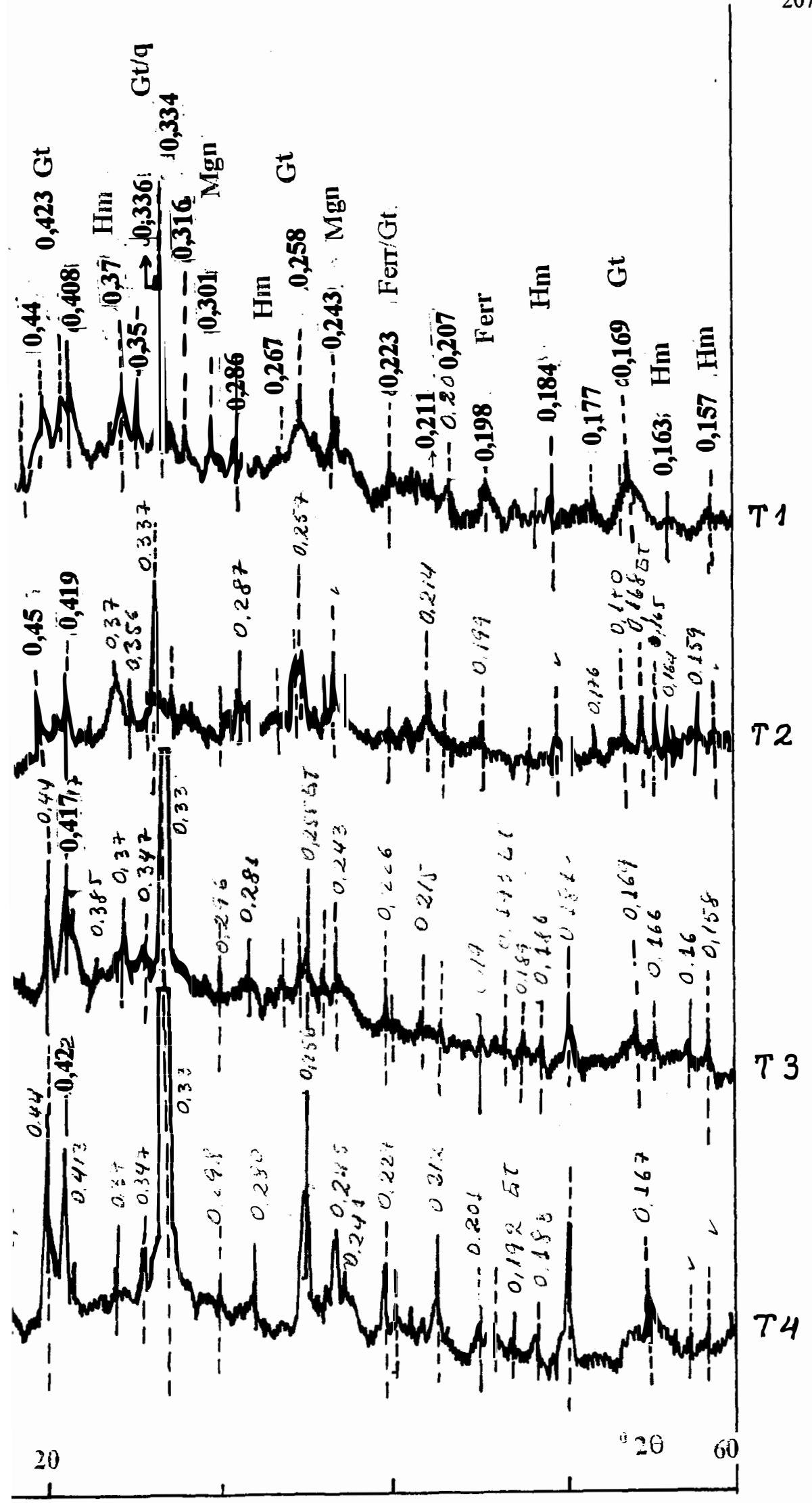

Figura Apêndice 3A. Difratogramas de raios-x em amostra tratada com NaOH5M dos horizontes Bt dos perfis 1 a 4 . 